Historic, archived document

Do not assume content reflects current scientific knowledge, policies, or practices. 
, 


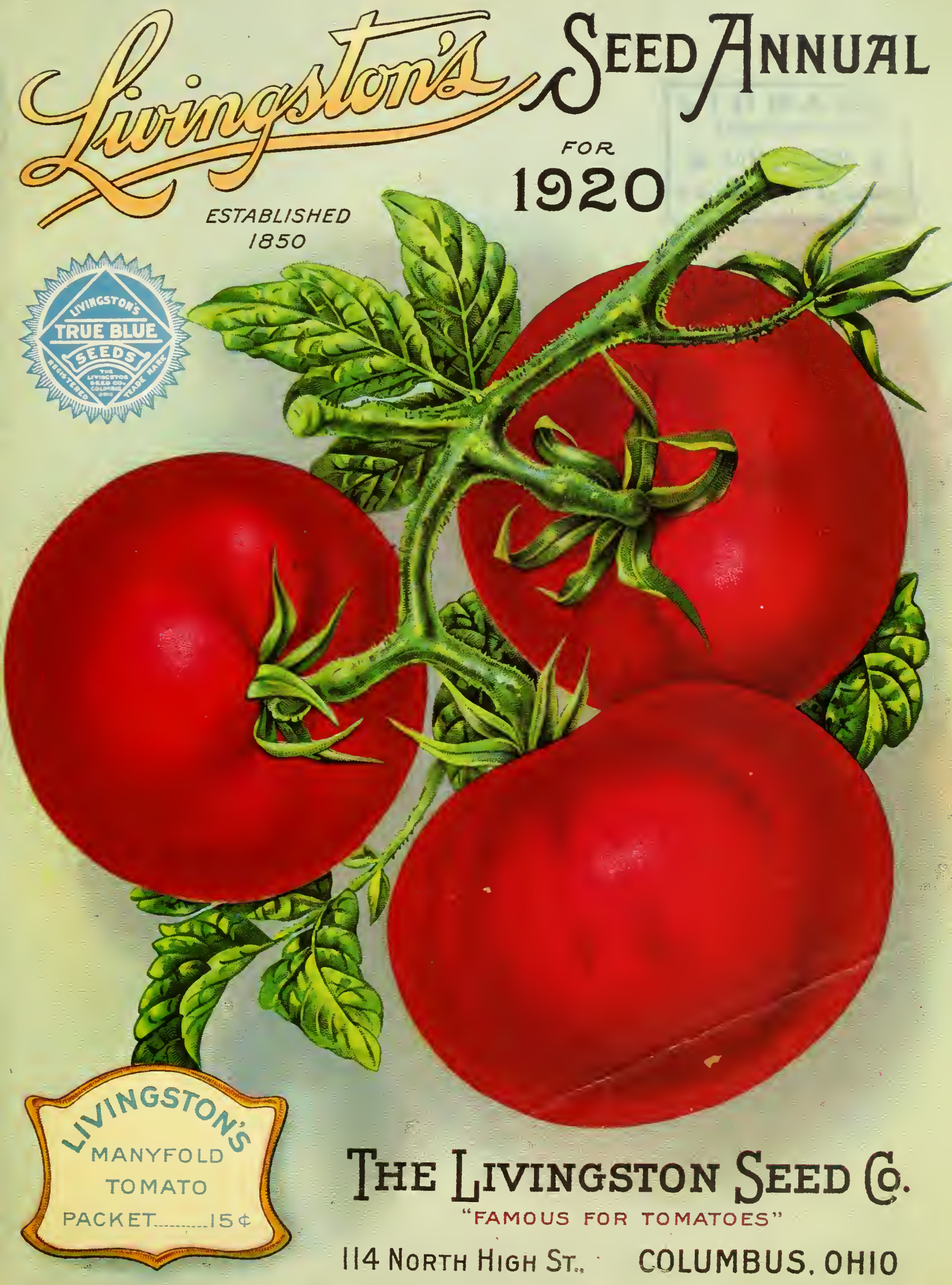




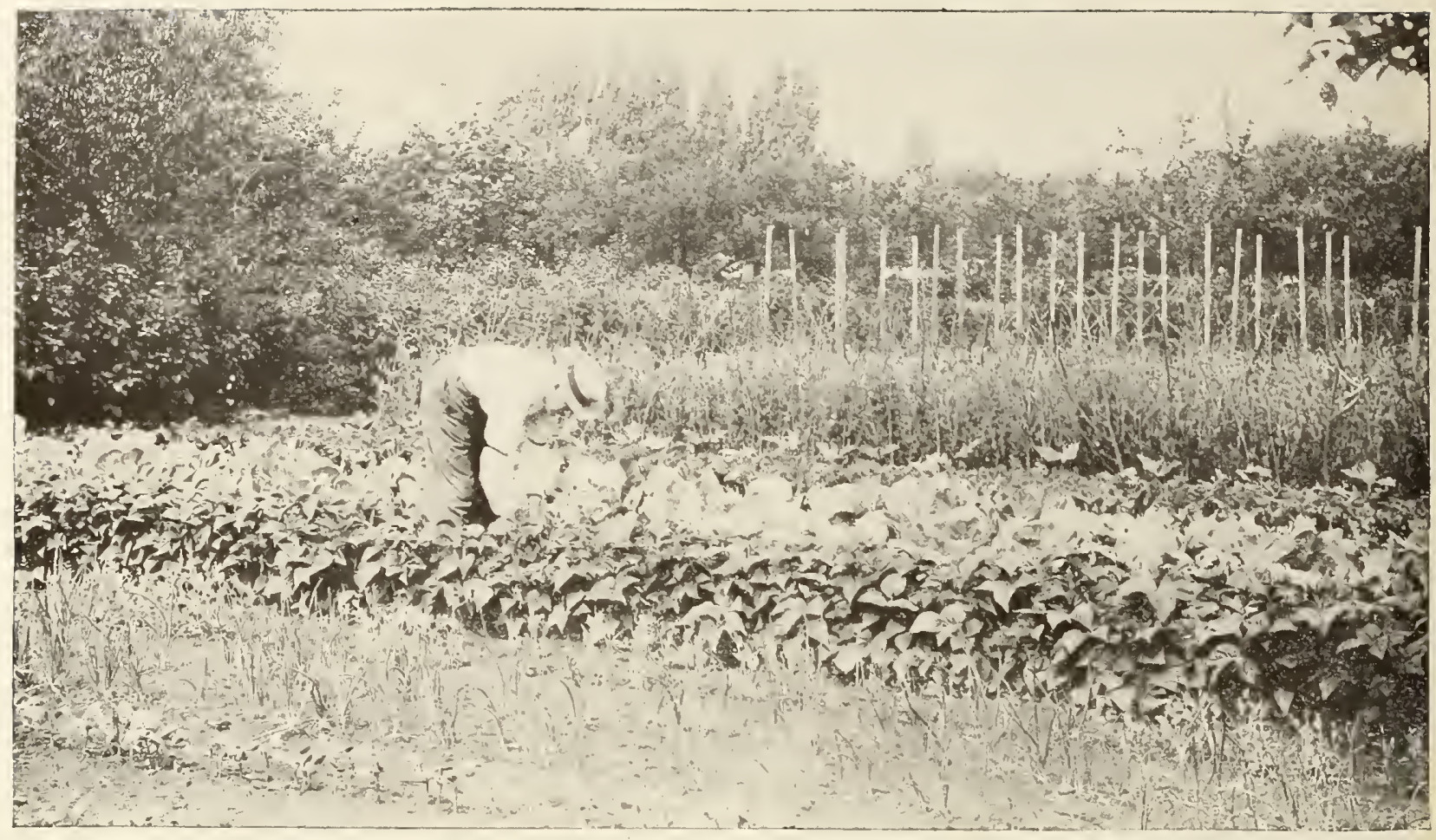

\section{Our Great Dollar Collection of "True Blue"}

\section{$\$ 1.00$ Postpaid or many years this collection has been considered the biggest Dollar's worth of really good seeds offered.

a damps, and out it goesThis Dollar Collection cannot be included with any special offers found in this atalogue. It is a great bargain as it is.

HERE IS WHAT ONE TOLIAR WILI BUY:

\section{Thirty-two (32) Liberal Packets, as Follows, for Only One Dollar}

\section{BEANS-Dwarf, Stringless Green Pod, Fin} BEANS-Dwarf, Iivingston's Hardy Wax. BEET-Detroit Dark Red.

BEFT-Early Eclipse.

CABBAGE-Henderson's Early Summer. Round head.

CABBAGE-Ideal Winter.

CARROT-Danvers. ..Big cropper; fine quality.

CARROT-Oxheart. Fine medium early sort.

CEIERY-Columbia. Early and good.

CUCUMBER-Iivingston's White Spine. Best slicer.

DIII-Tierb used in making pickies.

KALE-Siberian. Splendid for greens.

IETTUCE-Wonderful. A reliable heading sort.

IETTUCE-Curled Simpson. Fine early variety.
MUSKMEION-Rose Gem. Green flesh; early;

WATERMEION-Tom Watson. Quality very delicious OKRA-Kleckley's Favorite. ONION-Yellow Globe. Best for ceneral PARSNIP-Follow Crown. Large and cxtra sweet PARSIEY-Moss Curled. Very fine green variety. PEAS-Potlatch. Large pods, full of sweet peas. PEAS-Potlatch. Lalge pods, full of sweet pea RADISH-Cinciunati irarket. Long, red, early.

RADISH-Early Scarlet Turnip. A quick, crisp grower. SAISIFY-Mammoth Sandwich Island. Best sort. SPINACF-Imp. Thick Ieaf. Best for general use. SQUASH-Fubbard. Fine for winter use

SWEET CORN-County Gentleman. Fxtra Sweet. SWEET CORN-Iivingston's Early Sugar. Choice. TOMATO-Iivingston's Globe. Splendid pink variety.

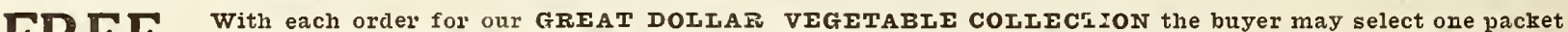

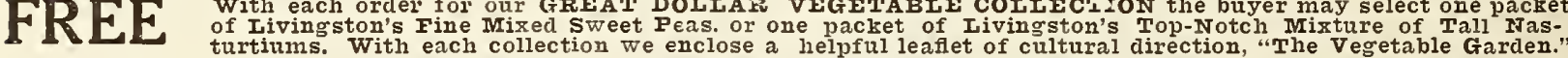

\section{0c Postpaid --. VEGETABLE SEEDS --. 50c Postpaid \\ Fifteen (15) Iiberal Packets, as Follows for Only Fifty Cents}

\section{BEANS-Stringless Green Pod. Fine}

BEET-Detroit Dark Red. Very early and tender.

CABBAGE-Henderson's Early Summer. Round head.

CARROT-Danvers. Big cropper, fine quality

5. CUCUMBER-Early Fortune. Green, shapely piclile.

6. IETTUCE-Curled Simpson. Fine early variety.
PARSNIP-Follow Crown. Large and extra sweet. PAR SIFY-Moss Curled. Very fine green variety.

PEAS-Potlatch. Laroe pods, full of sweet peas.

11. RADISI-Cincinnati Market. Long, red, early

12. SPINACF-Imp. Thick Ieaf. Best for general use.

14. TOMATO-Iivingston's Globe. Splendid pink variet. 


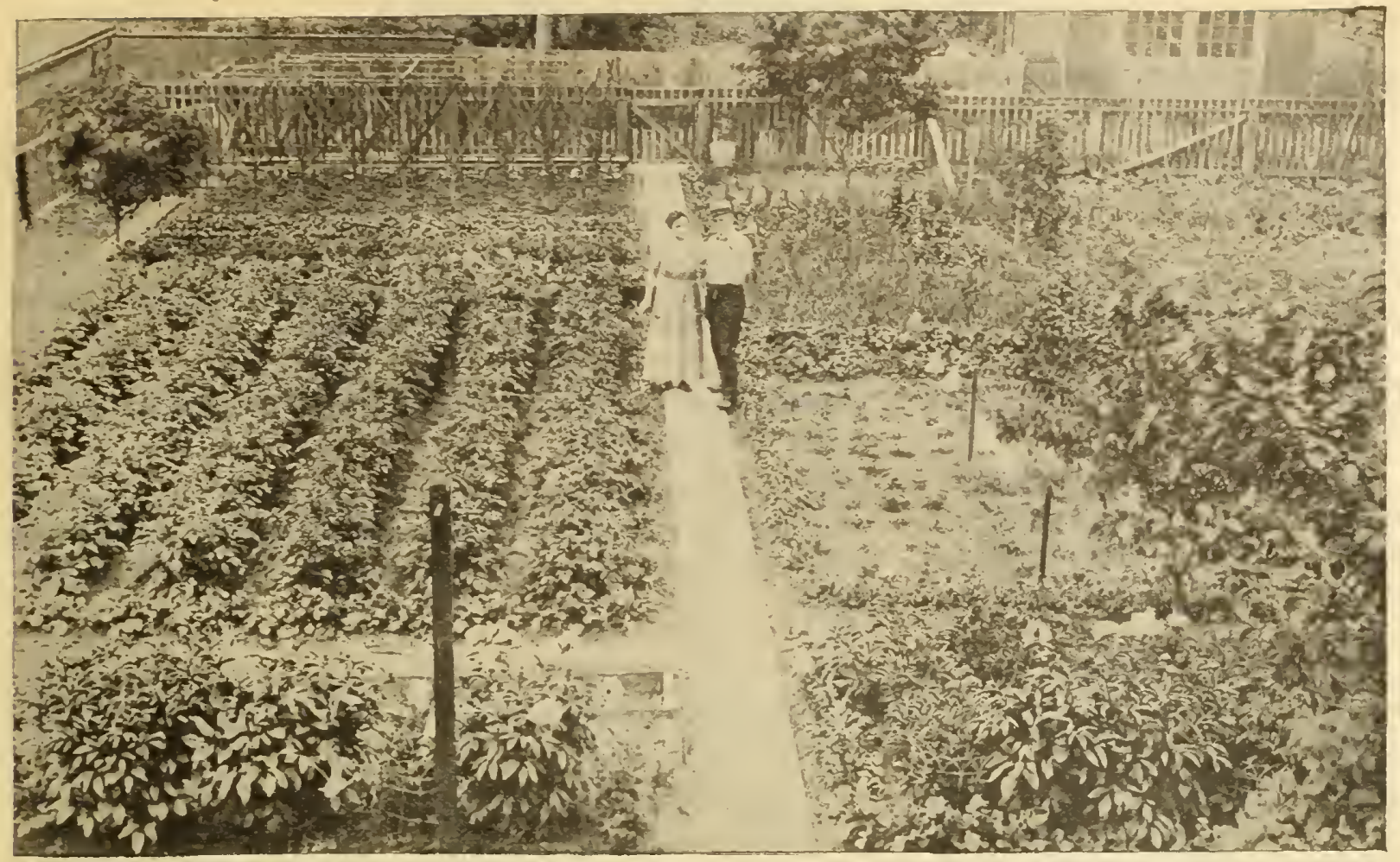

To Our Friends, Our Customers:

Columbus, O., January 1st, 1920.

In these reconstruction days we are finding some good results of the war, and one of them is the experience gained by many in war gardens. It had been a wonderful surprise to hundreds of men and women, as to the possibilities of even a small piece of ground, well taken care of when planted with a choice collection of vegetables and flower seeds. Even those of little or no previous gardening experience have done remarkably well, and have become enthusiastic amateur gardeners.

The delicious flavor of Swee Corn taken from the growing stalk, or the sweetness of fresh green peas right off the vines, or the crispness of Radishes and Lettuce directly from the garden to the table, was so novel and so satisfactory, that the garden started in back yards, and on vacant lots, as a war-time measure have now become permanent.

We are highly gratified to know that the Livingston's True Blue strains of seeds have contributed so largely to the success of these gardens, new and old.

Our satisfaction in conducting this business is not entirely measured by dollars and cents, but in the increasing demand as well as many expressions of satisfaction we have receivea by letter or from customers at our store.

We were happy in being able to help to win the war by supplying the best of seeds, which the season permitted, and trust we shall be favored with your further confidence, in helping to make your gardens greater successes-a source of constant pleasure and delight.

We have a more complete supply of seeds than for several years past and are better equipped for prompt service. The past season we came nearer filling orders the same day they were received than ever before and yet it was a rcord year as to the value of orders sent to us.

Wishing all our friends the fullest measure of success, we remain,

Yours to command,

THE LIVINGSTON SEED CO.,

True Blue Trial Grounds and Greenhouse日, near this City.

Columbus, Ohio.

Kirkersville Seed Farm, Kirkersville, Ohio.

Retail Store, 114 North High and 9.11 East Long St.

Seed Warehouse, 59-61 East Chestnut St. 


\title{
Important Suggestions
}

\author{
By carefully observing the following Directions, Mistakes and Misunderstandings will be very \\ largely avoided.
}

Columbus, Ohio, is a city of over 225,000 inhabitants, centrally located geographically, has 17 steam railroad systems, 11 electric roads, which practically cover the entire country, Express Companies, Telegraph and Telephone wires in all directions, which afford us unequalled facilities for receiving orders, shipping and procuring lowest rates to all parts of the country; besides you have the assurance of getting your order in the quickest possible time.

\section{Within Twenty-four Hours' Time, Normally, We Can Reach Two-thirds of the Population of the United States}

ALWAYS USE THE ORDER BLANK and envelope sent with this Catalogue when possible. Write plainly, keep a copy of your order, and be sure to sign your name, Postoffice, County and State every time you write to us. Extra Envelopes and Order Blanks will be sent on application, also additional Catalogues, if desired.

\begin{abstract}
SEND MONEY. Remittances should always accompany the order. Remittances may be made at our risk by any of the following methods: (1st and best)-Postoffice order; (2d)-Bank Draft; (3d)-Express Co. Money Order; (4th) Cash by Express in amounts not less than $\$ 5.00 ;(5 \mathrm{th})-$ Registered Letters. When money cannot be sent by either of the first four methods, it may be enclosed in a Registered Letter. The rates charged for Postoffice Orders and Express Money Orders are now so low this is the best way to remit where they can be obtained.
\end{abstract}

No GOODS SENT C. O. D. Unless cash to the amount of one-fourth the order accompanies the same.

SEEDS BY MAIL. Sending seeds by mail is a very important branch of our business, as we are now using an entire building apart from retail store, for the mail order and shipping department. Hence we are well prepared to fill orders promptly and correctly the day they are received in nearly all cases.

oUR PRICES. In comparing our mail prices, especially on heavy seeds, such as Peas, Beans and Corn, by the pound and two pounds, and other seeds by the pound and one-fourth pound, bear in mind that we pay the postage, unless otherwise noted.

ORDER EARIY. It is important to order as soon after you get the Cataloguc as convenient, then you will have your seeds at hand for planting when you want them; besides, if you want seeds in large quantities, they can be sent by freight much cheaper than by express. Small orders, however, can often go by express as cheaply.

IARGE ORDERS. Any Dealer, Market Gardener, Institution or any individual wishing seeds in large quantities is requested to mail us a list of what is wanted and we will promptly return it to you with the very lowest prices marked. A letter of inquiry may save you dollars if you want to buy in quantity.

SMAII ORDERS. If you want only a single packet, do not hesitate to order it. We take as much pains with small orders as with large ones. Small True Blue Seed orders are sure to grow larger

SHIPPING ORDERS. When goods are to be shipped by freight or express, give plain shipping directions; otherwise we use our best judgment in routing.

BE FREE TO WRITE US for any information pertaining to our business, on a separate sheet of paper from your order, as your letter goes to the general office and your order to Mail, Express, or other departments.
WE URGE customers to inform us promptly on the arrival of orders if anything proves otherwise than expected. We aim to make friends of our customers and mail orders receive the same careful attention that customers do over our counters, but we are only human and errors sometimes(though not often) occur. When they do we are willing and anxious to rectify them.

OUR SEED ANNUAI. Please show this seed Annual to your friends, and if you should receive an extra copy be kind enough to hand it to some neighbor interested in seeds, who will be pleased to get it. We will be glad to send a copy free to any of your friends likely to want seeds, in this or any other country. In return we will ask you to speak a good word for us to your friends and neighhors. An order this season, no matter how small, secures our catalogue for next season as soon as issued.

CHANGE OF ADDRESS. If you have changed, or intend to change your address, please let us know, and we will change it on our books, so that you will receive our Seed Annual at your new postoffice.

If you have Rural Mail Delivery be sure to give the Name and Number of your Route, if necessary, when ordering.

NON-WARANTEE. Complaints made that seeds are not good should quite as of ten be attributed to other causes as to the quality of the seeds. There are contingencies continually arising to prevent the very best seeds always giving satisfaction, such as sowing too deep, too shallow, in too wet or too dry soil; insects of all description destroying the plants as soon as, or before, they appear; wet weather, cold weather, frosts; chemical changes in the seeds induced by temperature, etc. Snil preparation for the reception of seed is very important. If not properly done, seed with very high germination is bound to perish. For all these reasons, it is impossible to guarantee seeds under all circumstances, therefore The Livingston Seed Company gives no warranty, expressed or implied, as to deseription, quality, productiveness or any other matter of any Seeds, Bulbs or Plants we sell, and will not be in any way responsible for the crop. We test all our seeds before sending them to cur customers, and should they fail to grow if promptly and properly tested by the customer, will replace the same amount or give value in others. We cannot afford, knowingly, to send out seeds doubtful as to vitality or purity, and you can get no better stocks of any seedsman, even though he deceitfully professes to warrant seeds. We have thought best to be frank in regard to this matter so there could be no misunderstanding. A guarantee from an irresponsible seedsman is of no value whatever. 


\section{ABOUT PARCELS POST}

W E give below a Parcel Post rate table for the convenience of those wishing goods sent by mail in larger quantities than are quoted "postpaid" herein. Bear in mind, however, that we pay the postage or express charges, unless otherwise noted, on all seeds up to and including pounds (Beans, Corn and Peas, two pounds). The price on other items does not include prepayment of this charge except as noted.

\begin{tabular}{|c|c|c|c|}
\hline $\begin{array}{l}\text { The rate for Seeds, Bulbs } \\
\text { Plants and Books is } 1 \\
\text { cent for each two ounces } \\
\text { up to } 8 \text { ounces regard- } \\
\text { less of distance. Over } 8 \\
\text { ounces the pound zone } \\
\text { rate applies. }\end{array}$ & $\begin{array}{l}\text { Local } \\
\text { Zone } \\
\text { City of } \\
\text { Cols. and } \\
\text { its rura] } \\
\text { routes } \\
\text { Postage } \\
\text { required } \\
\end{array}$ & $\begin{array}{c}\text { 1st } \\
\text { Zone } \\
\text { Not over } \\
50 \text { miles } \\
\text { from } \\
\text { Columbus } \\
\text { Postage } \\
\text { required } \\
\end{array}$ & $\begin{array}{l}\text { 2nd } \\
\text { Zone } \\
51 \text { to } 150 \\
\text { miles } \\
\text { from } \\
\text { Columbus } \\
\text { Postage } \\
\text { required }\end{array}$ \\
\hline $\begin{array}{lllll}\text { Over } & 8 & \text { oz. up to } & 1 & \mathrm{lb} . \\
\text { Over } & 1 & \mathrm{lb} \text {. up to } & 2 & \mathrm{lbs} \text {. } \\
\text { Over } & 2 & \mathrm{lbs} \text {. up to } & 3 & \mathrm{lbs} \text {. } \\
\text { Over } & 3 & \mathrm{lbs} \text {. up to } & 4 & \mathrm{lbs} \text {. } \\
\text { Over } & 4 & \mathrm{lbs} \text {. up to } & 5 & \mathrm{lbs} \text {. } \\
\end{array}$ & $\begin{array}{l}5 c \\
6 c \\
6 c \\
7 c \\
7 c \\
\end{array}$ & $\begin{array}{l}5 c \\
6 c \\
7 c \\
8 c \\
9 c \\
\end{array}$ & $\begin{array}{l}5 c \\
6 c \\
7 c \\
8 c \\
9 c \\
\end{array}$ \\
\hline 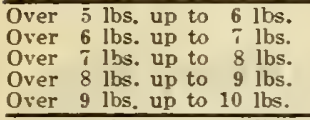 & $\begin{array}{r}8 \mathrm{c} \\
8 \mathrm{c} \\
9 \mathrm{c} \\
9 \mathrm{c} \\
10 \mathrm{c} \\
\end{array}$ & $\begin{array}{l}10 \mathrm{c} \\
11 \mathrm{c} \\
12 \mathrm{c} \\
13 \mathrm{c} \\
14 \mathrm{c} \\
\end{array}$ & $\begin{array}{l}10 c \\
11 c \\
12 c \\
13 c \\
14 c \\
\end{array}$ \\
\hline $\begin{array}{l}\text { Over } 10 \text { lbs. up to } 11 \text { lbs. } \\
\text { Over } 11 \text { lbs. up to } 12 \text { lbs. } \\
\text { Over } 12 \text { lbs. up to } 13 \text { lbs. } \\
\text { Over } 13 \text { lbs. up to } 14 \text { lbs. } \\
\text { Over } 14 \text { lbs. up to } 15 \text { lbs. }\end{array}$ & $\begin{array}{l}10 \mathrm{c} \\
11 \mathrm{c} \\
11 \mathrm{c} \\
12 \mathrm{c} \\
12 \mathrm{c}\end{array}$ & $\begin{array}{l}15 \mathrm{c} \\
16 \mathrm{c} \\
17 \mathrm{c} \\
18 \mathrm{c} \\
19 \mathrm{c}\end{array}$ & $\begin{array}{l}15 \mathrm{c} \\
16 \mathrm{c} \\
17 \mathrm{c} \\
18 \mathrm{c} \\
19 \mathrm{c} \\
\end{array}$ \\
\hline $\begin{array}{l}\text { Over } 15 \text { lbs. up to } 16 \mathrm{lbs} \text {. } \\
\text { Over } 16 \mathrm{lbs} \text { up to } 17 \mathrm{lbs} \text {. } \\
\text { Over } 17 \mathrm{lbs} \text {. up to } 18 \mathrm{lbs} \text {. } \\
\text { Over } 18 \mathrm{lbs} \text {. up to } 19 \mathrm{lbs} \text {. } \\
\text { Over } 19 \mathrm{lbs} \text {. up to } 20 \mathrm{lbs} \text {. }\end{array}$ & $\begin{array}{l}13 c \\
13 c \\
14 c \\
14 c \\
15 c \\
\end{array}$ & $\begin{array}{l}20 c \\
21 c \\
22 c \\
23 c \\
24 c \\
\end{array}$ & $\begin{array}{l}20 c \\
21 c \\
22 c \\
23 c \\
24 c \\
\end{array}$ \\
\hline $\begin{array}{l}\text { Over } 20 \mathrm{lbs} \text {. up to } 21 \mathrm{lbs} \text {. } \\
\text { Over } 21 \text { lbs, up to } 22 \mathrm{lbs} \text {. } \\
\text { Over } 22 \mathrm{lbs} \text {. up to } 23 \mathrm{lbs} \text {. } \\
\text { Over } 23 \mathrm{lbs} \text {, up to } 24 \mathrm{lbs} \text {. } \\
\text { Over } 24 \text { lbs, up to } 25 \mathrm{lbs} \text {. }\end{array}$ & $\begin{array}{l}15 \mathrm{c} \\
16 \mathrm{c} \\
16 \mathrm{c} \\
17 \mathrm{c} \\
17 \mathrm{c} \\
\end{array}$ & $\begin{array}{l}25 c \\
26 c \\
27 c \\
28 c \\
29 c \\
\end{array}$ & $\begin{array}{l}25 c \\
26 c \\
27 c \\
28 c \\
29 c \\
\end{array}$ \\
\hline $\begin{array}{l}\text { Over } 25 \mathrm{lbs} \text {. up to } 26 \mathrm{lbs} \text {. } \\
\text { Over } 26 \mathrm{lbs} \text {. up to } 27 \mathrm{lbs} \text {. } \\
\text { Over } 27 \mathrm{lbs} \text {. up to } 28 \mathrm{lbs} \text {. } \\
\text { Over } 28 \mathrm{Jbs} \text { up to } 29 \mathrm{lbs} \text {. } \\
\text { Over } 29 \mathrm{lbs} \text {. up to } 30 \mathrm{lbs} \text {. }\end{array}$ & $\begin{array}{l}18 \mathrm{c} \\
18 \mathrm{c} \\
19 \mathrm{c} \\
19 \mathrm{c} \\
20 \mathrm{c} \\
\end{array}$ & $\begin{array}{l}30 \mathrm{c} \\
31 \mathrm{c} \\
32 \mathrm{c} \\
33 \mathrm{c} \\
34 \mathrm{c} \\
\end{array}$ & $\begin{array}{l}30 \mathrm{c} \\
31 \mathrm{c} \\
32 \mathrm{c} \\
33 \mathrm{c} \\
34 \mathrm{c} \\
\end{array}$ \\
\hline $\begin{array}{l}\text { Over } 30 \text { lbs. up to } 31 \text { lbs. } \\
\text { Over } 31 \text { lbs. up to } 32 \text { lbs. } \\
\text { Over } 32 \text { lbs. up to } 33 \text { lbs. } \\
\text { Over } 33 \text { lbs. up to } 34 \text { lbs. } \\
\text { Over } 34 \text { lbs. up to } 35 \text { lbs. } \\
\end{array}$ & $\begin{array}{l}20 \mathrm{c} \\
21 \mathrm{c} \\
21 \mathrm{c} \\
22 \mathrm{c} \\
22 \mathrm{c} \\
\end{array}$ & $\begin{array}{l}35 c \\
36 c \\
37 c \\
38 c \\
39 c \\
\end{array}$ & $\begin{array}{l}35 \mathrm{c} \\
36 \mathrm{c} \\
37 \mathrm{c} \\
38 \mathrm{c} \\
39 \mathrm{c} \\
\end{array}$ \\
\hline $\begin{array}{l}\text { Over } 35 \text { lbs. up to } 36 \text { lbs. } \\
\text { Over } 36 \text { lbs. up to } 37 \text { lbs. } \\
\text { Over } 37 \text { lbs. up to } 38 \text { lbs. } \\
\text { Over } 38 \text { lbs. up to } 39 \text { lbs. } \\
\text { Over } 39 \mathrm{lbs} \text {. up to } 40 \text { lbs. } \\
\end{array}$ & $\begin{array}{l}23 c \\
23 c \\
24 c \\
24 c \\
25 c \\
\end{array}$ & $\begin{array}{l}4 c \\
41 c \\
42 c \\
43 c \\
44 c \\
\end{array}$ & $\begin{array}{l}4 c \\
41 c \\
42 c \\
43 c \\
44 c \\
\end{array}$ \\
\hline $\begin{array}{l}\text { Over } 40 \text { lbs. up to } 41 \text { lbs. } \\
\text { Over } 41 \text { lbs. up to } 42 \mathrm{lbs} \text {. } \\
\text { Over } 42 \text { lbs. up to } 43 \text { lbs. } \\
\text { Over } 43 \text { lbs. up to } 44 \text { lbs. } \\
\text { Over } 44 \text { lbs. up to } 45 \mathrm{lbs} \text {. }\end{array}$ & $\begin{array}{l}25 c \\
26 c \\
26 c \\
27 c \\
27 c \\
\end{array}$ & $\begin{array}{l}45 c \\
46 c \\
47 c \\
48 c \\
49 c \\
\end{array}$ & $\begin{array}{l}45 c \\
46 c \\
47 c \\
48 c \\
49 c \\
\end{array}$ \\
\hline $\begin{array}{l}\text { Over } 45 \text { lbs. up to } 46 \text { lbs. } \\
\text { Over } 46 \text { lbs. up to } 47 \text { lbs. } \\
\text { Over } 47 \text { lbs. up to } 48 \text { lbs. } \\
\text { Over } 48 \text { lbs. up to } 49 \text { lbs. } \\
\text { Over } 49 \text { lbs. up to } 50 \text { lbs. }\end{array}$ & $\begin{array}{l}28 c \\
28 c \\
29 c \\
29 c \\
30 c\end{array}$ & $\begin{array}{l}50 c \\
51 c \\
52 c \\
53 c \\
54 c\end{array}$ & $\begin{array}{l}50 \mathrm{c} \\
51 \mathrm{c} \\
52 \mathrm{c} \\
53 \mathrm{c} \\
54 \mathrm{c}\end{array}$ \\
\hline
\end{tabular}

\section{Two Valuable Books on Vegetable Gardening}

\section{"Home Vegetable Gardening"}

By ADOLPH KRUHX of the Garaen Magazine

This book tells, in a practical way, just how to proceed with a garden, sowing of the seed, kind of soil best for the different vegetables, lay-out, etc. It is just what you need to assist you with your garden, whether you are an amateur or an old hand at the business. A book of about 300 pages fully illustrated with more than 200 photographic reproductions, also 32 four-color illustrations. Cloth bound, Price $\$ 1.35$, postpaid. Order a copy today.

If you have never ordered one of our great Dollar Collections of Vegetable Seed, better try one this geason. It is a real bargain. We also offer a Half Dollar Collection, an equally good bargain. See the second cover page.

\begin{tabular}{|c|c|c|c|c|c|}
\hline $\begin{array}{l}3 \text { rd } \\
\text { one } \\
1 \text { to } \\
\text { miles } \\
\text { rom } \\
\text { umbus } \\
\text { stage } \\
\text { uired }\end{array}$ & $\begin{array}{c}4 \text { th } \\
\text { Zone } \\
301 \text { to } \\
600 \text { miles } \\
\text { from } \\
\text { Columbus } \\
\text { Pastage } \\
\text { required }\end{array}$ & $\begin{array}{c}\text { 5th } \\
\text { Zone } \\
601 \text { to } \\
1000 \mathrm{mi} \text {. } \\
\text { from } \\
\text { Columbus } \\
\text { Postage } \\
\text { required }\end{array}$ & $\begin{array}{c}\text { 6th } \\
\text { Zone } \\
1001 \text { to } \\
1400 \mathrm{mi} \text {. } \\
\text { from } \\
\text { Columbus } \\
\text { Postage } \\
\text { required }\end{array}$ & $\begin{array}{c}\text { 7th } \\
\text { Zone } \\
1401 \text { to } \\
1800 \mathrm{mi} . \\
\text { from } \\
\text { Columbus } \\
\text { Postage } \\
\text { required }\end{array}$ & $\begin{array}{c}8 \text { th } \\
\text { Zone } \\
\text { Over } 1800 \\
\text { miles } \\
\text { from } \\
\text { Columbus } \\
\text { Postage } \\
\text { required }\end{array}$ \\
\hline
\end{tabular}

\begin{tabular}{cccccc} 
& required & required & required & required & required \\
\hline $6 \mathrm{c}$ & $7 \mathrm{c}$ & .08 & .09 & .11 & .12
\end{tabular}

\begin{tabular}{rrrrrr}
$6 c$ & $7 c$ & .08 & .09 & .11 & .12 \\
$8 c$ & $11 c$ & .14 & .17 & .21 & .24 \\
$10 c$ & $15 c$ & .20 & .25 & .31 & .36 \\
$12 c$ & $19 c$ & .26 & .33 & .41 & .48 \\
$14 c$ & $23 c$ & .32 & .41 & .51 & .60 \\
\hline $16 c$ & $27 c$ & .38 & .49 & .61 & .72 \\
$18 c$ & $31 c$ & .44 & .57 & .71 & .84 \\
$20 c$ & $35 c$ & .50 & .65 & .81 & .96 \\
$22 c$ & $39 c$ & .56 & .73 & .91 & 1.08 \\
$24 c$ & $43 c$ & .62 & .81 & 1.01 & 1.20 \\
\hline $26 c$ & $47 c$ & .68 & .89 & 1.11 & 1.32 \\
$28 c$ & $51 c$ & .74 & .97 & 1.21 & 1.44 \\
$30 c$ & $55 c$ & .80 & 1.05 & 1.31 & 1.56 \\
$32 c$ & $59 c$ & .86 & 1.13 & 1.41 & 1.68 \\
$34 c$ & $63 c$ & .92 & 1.21 & 1.51 & 1.80 \\
\hline $36 c$ & $67 c$ & .98 & 1.29 & 1.61 & 1.92 \\
$38 c$ & $71 c$ & 1.04 & 1.37 & 1.71 & 2.04 \\
$40 c$ & $75 c$ & 1.10 & 1.45 & 1.81 & 2.16 \\
$42 c$ & $79 c$ & 1.16 & 1.53 & 1.91 & 2.28 \\
$44 c$ & $83 c$ & 1.22 & 1.61 & 2.01 & 2.40 \\
\hline
\end{tabular}

\section{Insured Parcel Post}

Packages up to $\$ 25.00$ in value will be insured for their full value on payment of a fee of 5 cents for each package in addition to the regular post rates. Packages in value over $\$ 25.00$ will be insured for their full value, but not to exceed $\$ 50.00$ for a fee of 10 cents for each package in addition to the regular Parcel Post rates. If you desire your package insured. send the insurance fee in addition to the amount you send to

\section{Weight Limit}

In the local, first and second zones, packages will be delivered by Parcel Post, weighing up to 70 pounds. In the third to eighth zones, the weight limit is 50 pounds.

\section{Size Limit}

The size of the parcel in no case is to exceed 72 inches in length and girth combined. In other words, the circumfernot exceed 72 inches.

\section{Returning Goods}

Should you ever find it necessary to return goods by Parcel Post, never put a letter or any money in the package, as that would make the whole shipment bear a first-class postage over a string. Always put your name and address in the upper left-hand corner.

\section{The Gardenette}

A complete garden guide; tells how to grow choice vegetables by the celebrated Sandwich system, how to start early, thrifty plants without a hotbed; how to grow melons, cucumbers, etc., by the new Post Hole Method; how to stimulate quick germination, and induce vigorous one square rod, on any kind of soil, and other new and valuable methods of gardening, not idle theories, but successful facts. Finely illustrated. Cloth bound, $\$ 1.25$. postpaid.

Edw. Garthwait, New Haven Co., Coun., writes: "Would like to have you please send me a $\$ 1.00$ box of assorted seeds as I was more than pleased with the box I got from you lasî year. I certainly had good luck. I don't want others."

W. P. Deakin, Washington Co., Pa., writes, A pril 16, 1918 as follows: "My One Dollar Collection arrived on Thursday the 11 th and my second order of the 8 th arrived today. I was very much pleased with both orders and the prompt 


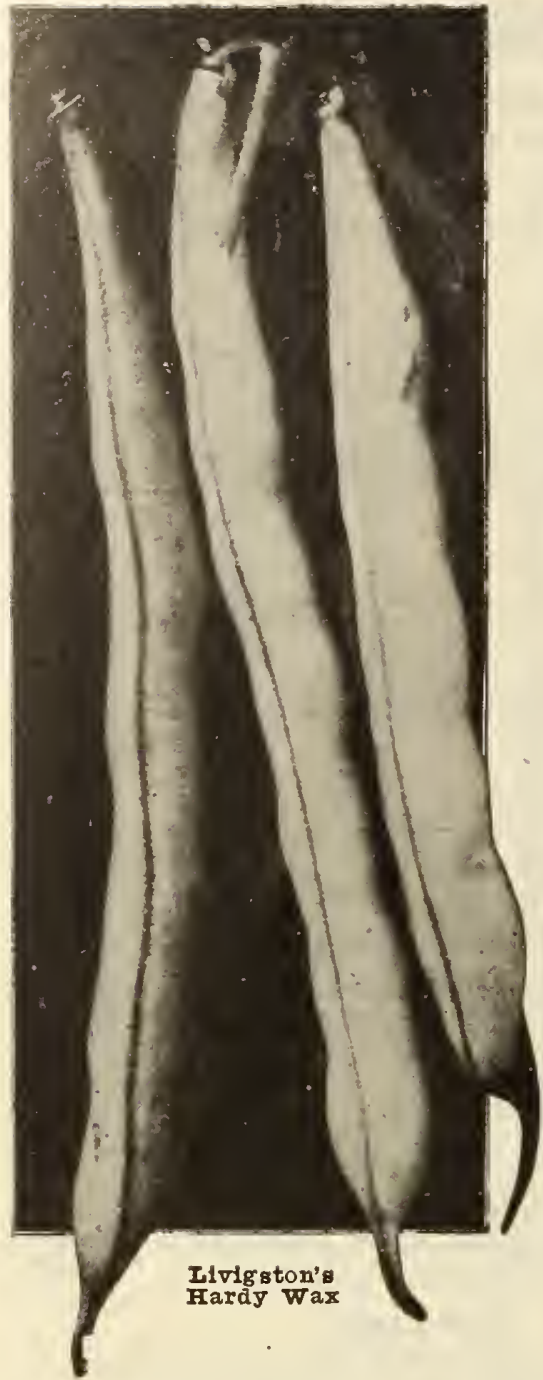

\section{Novelties and Specialties for 1920}

You will find under this heading new varieties worthy of trial, and others of such value as to warrant our giving them special mention. A number of novelties are offered each year which, after growing on our trial grounds, prove no better than standard varieties, if as good, so that in line with our policy of furnishing the best seeds procurable we endeavor to furnish in new types, only such as have made good on our trial grounds. There are varieties which while not new in the strictest sense of the word, are of recent introduction and demand special notice as being much superior to ordinary types, and these we hope our customers will try along with some of the novelties, all of which will prove of interest and aid in the development of a more productive and profitable garden.

\section{Livingston's Superior Beans}

\section{Livingston's Pencil Pod Wax}

This is the favorite wax podded canning sorts. Pods are round, meaty and entirely. stringless. For full description see page 9. Pkt., 15c.; $1 / 2$ 1b., 25c.; lb., 40c.; 2 lbs., 70c.; 7 lbs., $\$ 1.70 ; 15$ lbs., $\$ 3.15$.

\section{Bountiful}

An excellent green podded variety. Pods are fiat but very meaty an stringless. For full description and illustration, see page 10 . Pkt., 15c.;

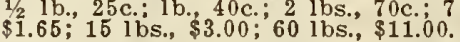

\section{Stringless Green Pod}

We do not know of a more popular variety than this. The handsome green pods are round, nearly straight, green pods are round, nearly straight, and illustration see page 10. Pkt., and illustration see page 10 . Pkt.; 7 ibs., $\$ 1.65 ; 15$ ibs., $\$ 3.00 ; 60$ lbs., 11.00 .

\section{Wardwell's Kidney Wax}

Immensely productive. One of the handsomest Wax Podded Beans. Early; vine medium, erect, hardy, productive. Pods long, broad flat, brittle and of a delicate waxy yellow. Very attractive market sort. Pkt., 15 c.; $1 / 2$ 1b., 25 c.; lb., $45 \mathrm{c} . ; 2$ lbs., $80 \mathrm{c}$.;.

\section{"Sure Crop" Stringless Wax}

Hardy-Blight-Resistant-Fleshy, Stringless Pods

Plants are very thrifty and hardy. Thick, leathery leaves resist blight admirably and help this sort to stand a remarkable amount of dry weather. Sure Crop Stringless Wax in the Bean "par excellence" for dry sections. Pods average 6 inches long, are flat. thick and fleshy, and entirely stringless. Pkt., 15c.; 1/2 1b., 25c. 1b., 40c.; 2 lbs., $70 \mathrm{c}$.; lbs., \$1.75; 15 lbs., $\$ 3.25$.

\section{Livingston's Hardy Wax}

High Quality-Stringless-You can't find a stronger or more healthy grower than this variety. It resists disease and grows in spite of unfavorable weather, and when it comes to quality they are unsurpassed in their class. We made pretty strong claims for Livingston's Hardy Wax when we first introduced it, but we haven't taken back a word that we said. It is of great value either for market or home garden. Hardy Wax is a good shipper and its great beauty makes it salable anywhere Pods are very solid, meaty and tender, absolutely stringless and lbs., $\$ 1.90 ; 15$ lbs., $\$ 3.50 ; 60$ lbs., $\$ 13.00$.

\section{Chinese Cabbage}

Also innown as "Celery Cabbage," "Odorless Cabbage," "ChlAlso nese Lree, cate flavor, resembles a stal or celery nd is in great demand head. It is as tender as head lettuce and is in great demand cooked quickly.

Culture, Storing for Winter, etc., are same as for Cabbage. Our experijer is that chinese Cabbage can not be grown successfully as a Spring early in August. We offer two varieties, as follows.

$P_{e}$ Tsal-Produces a long slender head, often measuring 20 inches in length outer leaves light green, inside is of a beautiful creamy yellow, very solid heads. Pkt, 10c.; 1/2 oz., 15c. oz., $25 \mathrm{c}$.; $1 / 4$ lb., $75 \mathrm{c}$; ; $1 \mathrm{~b}$., $\$ 2.50$.

Wong Boir-The heads of this sort are shorter and of greater diameter than the above and average heavier. Wong lok is more savoy leaved than Pe Tsai, thus bespeaking fine quality. We belleve it is a surer header than the above sort. Pkt., 10c.; oz., 25c.; oz., 45c.; 1/4 lb., $\$ 1.40 ; 1$ b., $\$ 5.00$

All Prices Quoted In This Catalogue are subject to Change without rotice

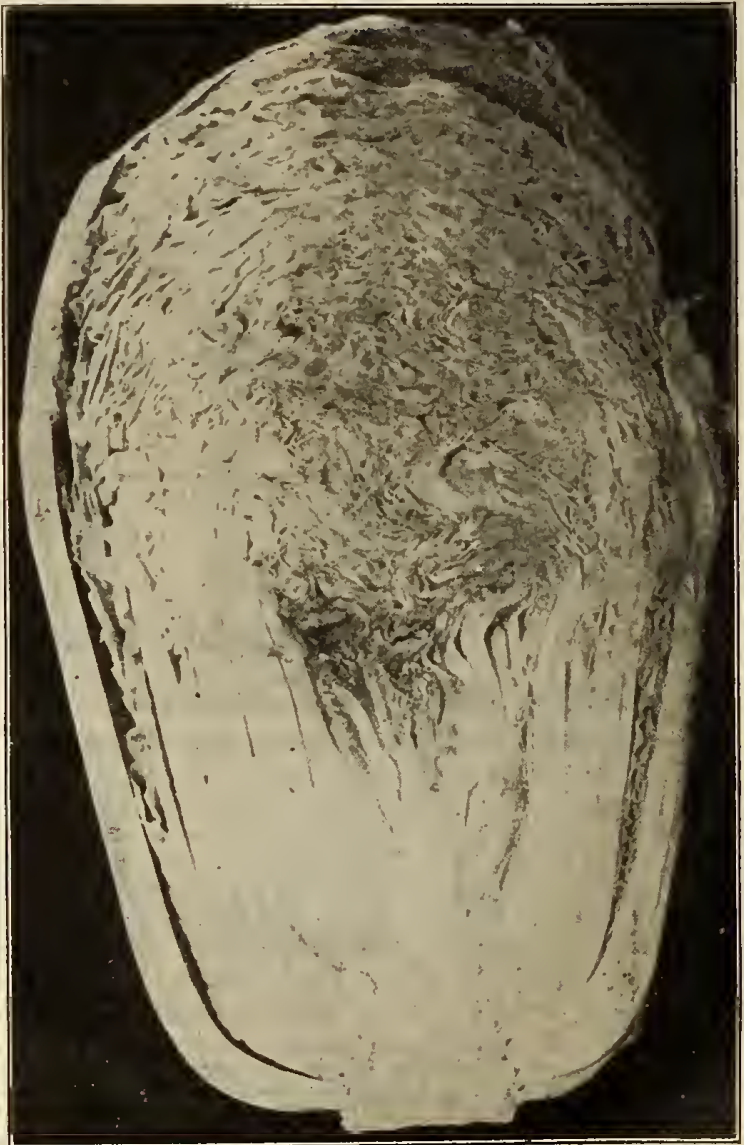

Chinese Cabbage-Wong-Bok 


\section{Livingston's Snowhite Celery}

It is without rival in purity of color: crisp, tender and of good size. In vigor of growth, ease of blaniching. richness of flavor and beauty of stalk, "Snowhite" is ideal. Single stalks sometimes weigh $21 / 2$ pounds, and ivite frequently 2 pounds. It grows solid on all kinds of soil and keeps better than a great many of the best standard varieties. We are pleased to announce that we have a good supply of this most excellent sort this season. Pkt., 10c.; 1/2 Oz., 25 c.; oz., 45c.; 1/4 1b., $\$ 1.50$.

\section{Golden Self-Blanching Celery}

This grand Celery is of French origin. 1t has the demand above all other sorts because of its many superb qualities. lt has the same selfblanching habit as Thite Plume, but is much heavier and more compact, though not so early. Grows to good size, is very tender and free from strings, the heart large and solid, crisp, brittle, of excellent quality and very beautiful.

American Grown Seed from French Stock Seed-This has proven after repeated trials to be equal to French grown stock. Plkt., $10 \mathrm{c}$; $1 / 2$ oz., 25c. oz., $45 \mathrm{c} . ; 1 / 4$ lb., $\$ 1.40$; lb., $\$ 5.00$.

French Grown Seed-From one of our most careful growers. Plit, 15c. $1 / 4$ oz., 35 c.; 1/2 oz,. 55c.; oz., $\$ 1.00 ; 1 / 4$ lb., $\$ 3.25 ; 1$ b., $\$ 12.00$.

\section{Easy Blanching Celery}

A variety of comparatively recent introduction which promises to take rank with some of the leading standard sorts. The plant is of medium size and a very robust grower, having broad thick stalks with shallow ribs. it is very tender and crisp and the quality is exceptionally fine. The originator makes the claim that Easy Blanching excels most of the standard inator makes the claim that Easy Blanching excels
season. Pkt., 10c.; $1 / 2$ oz., $25 \mathrm{c}$.: oz., $45 \mathrm{c} .: 1 / 1 / \mathrm{lb}$., $\$ 1.50$.

Id. Ir. Sturzinger, IHe County, Ohio, writes, February 14, 1919: "I think your Copenhagen Market Cabbage the finest ever."

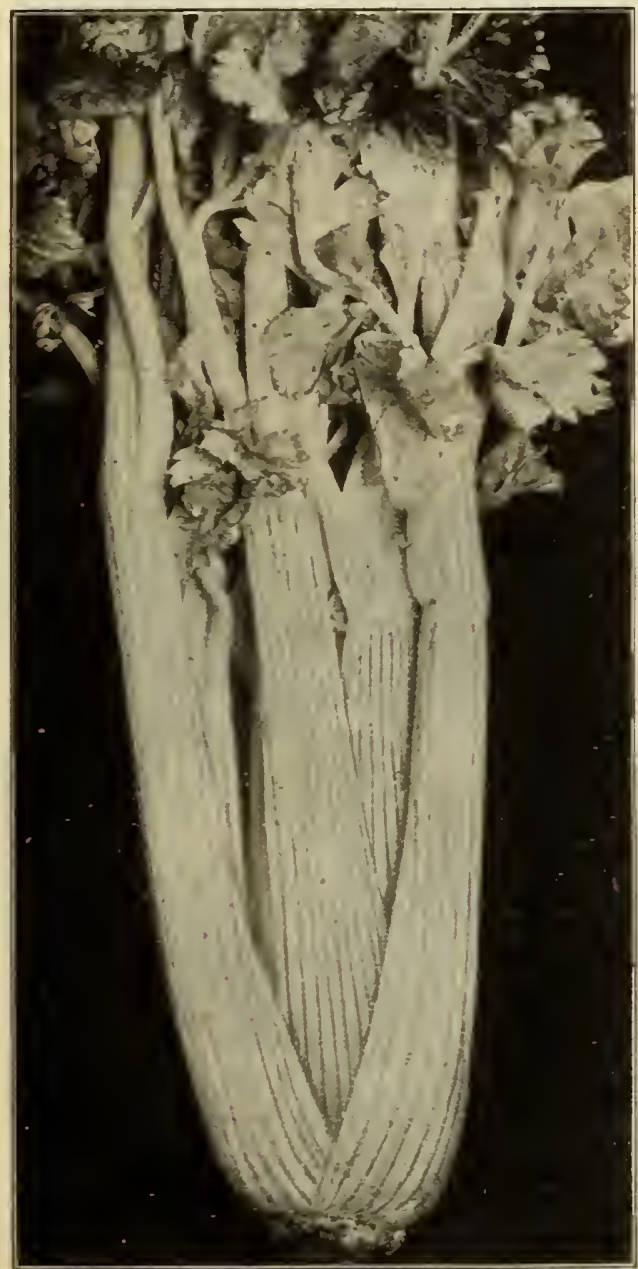

Golden Self-Blanching

\section{Copenhagen Market Cabbage}

splendid new extra-early round-headed sort which matures as early as the Wakefields and is of much larger size. Each plant forms perfect, tightly folded head, averaging five to eight pounds in weigh and about eight inches in diameter each way. The compact growth o the plant, the solidity of the head, its excellent flavor, and extrem earliness-all combine to make Copenhagen Market one of the mos meritorious Cabbages that have come to our notic

\section{Livingston's Earliest on Earth Sweet Corn}

Records on nur trial grounds for the vast four years show it to be earliest of all golden sorts, including such well-known extra-early varieties as "Peep O' Day," "Golden Bantam," "Nordheims," "Premo," anc all strains of Cory. Planted May 15, it was leady for market in 6 days. It is about a week earlier than Golden Bantam. Having 10 to 12 rows of grains, gaps in ears are prevented. Ears run about 6 inche in length in roasting ear stage. Are produced on short stalks. account of extreme earliness, other crops may be easily secured on same ground the same season. Pkt., 10c.; $1 / 2$ lb., $20 \mathrm{c}$; $1 \mathrm{~b}_{\text {., }} 30 \mathrm{c}$.; 2 11

\section{Aristocrat Sweet Corn}

Follows Mammoth White Cory in season. A very desirable variety with exceedingly large ears for an early, dwarf sort, ears 8 inches long, with ery broad grains: very productive. Pkt, 10c.; 1/ lb., 20c.; 1b., 30c.; 2 lbs., $55 \mathrm{c}$ By express, not paid: $G$ lbs. $\$ 1.25 ; 12$ lbs., $\$ 2.15$.

\section{Livingston's New Tom Thumb Pop-Corn}

(See illustration.) A great many people like to grow Pop-Corn, but there is so much difference in the popping qualities of the various varieties that one hesitates to offer anything in the line unless it has real merit. In this variety we havé a dwarf growing corn, a heavy yielder of attractive ears, peculiar in form, but the grain is very similar to the best strain of White Rice Pop-Corn. The ears are short and thick, and run very uniform. Of a pearly white and the grain is of excellent popping quality and flavor after belng popped. We recommend Tom Thumb, believing it will give general. satisfaction. Plit., 10c.; $1 / 2 \mathrm{lb}$. 20c.; 1b., 30c.; 2 lbs., 50c. By express, not paid: 5 lbs., 90c.; 25 lbs., \$1.25,

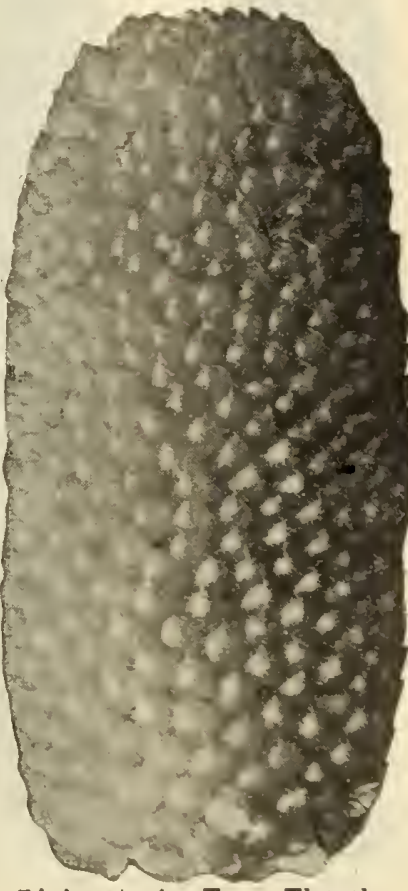
Pop Corn
Livingston's Tom Thumb 


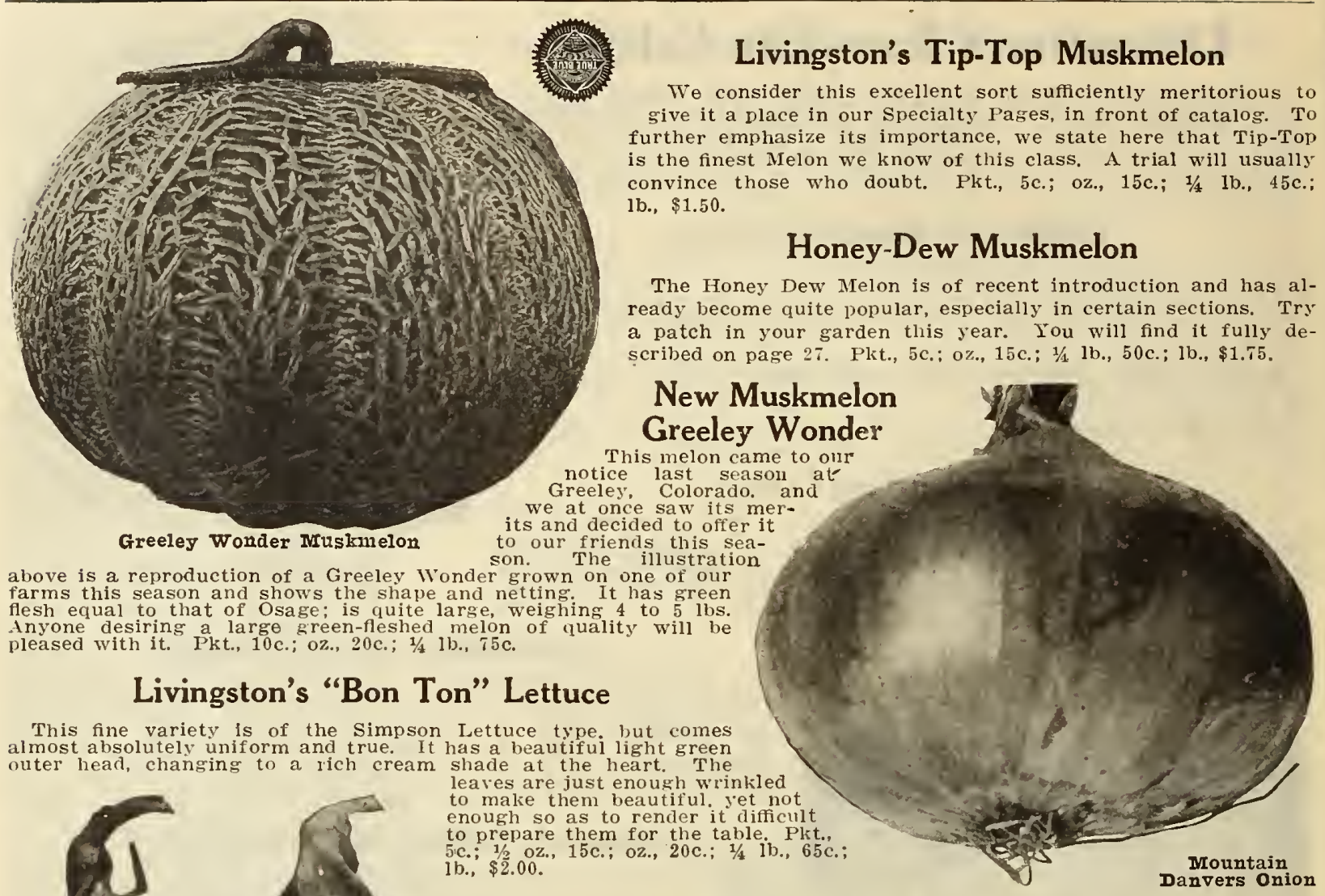

\section{New Onion Mountain Danvers}

This new sort is not as round as Globe Danvers, nor as flat as the Flat Danvers. It is one of the very earliest varieties and seems to ripen practically all at once. Color is a heavy vellow, shadine to brown. It is an excellent keeper and shows less shrinkage than any other variety. The skin is thick and heavy, which makes a good shipping sort. Plit., $10 \mathrm{c}$.; $1 / 2$ oz., $15 \mathrm{c}$.; oz., $25 \mathrm{c}$; ; $1 / 4$ 1b., $75 \mathrm{c}$.; Ib., $\$ 2.50$.

\section{Livingston's Yellow Beauty Onion}

Grows the Hardest, Smooth. est Roundest, Best-Keeping Onions or Onion sets.

Livingston's Fellow Beauty is a lemon-yellow sort, of very fine and firm texture, especially adapted to growing sets and adapted to growing sets and They often keep until June in They of ten keep until June in fine condition. Pkt., 10c.: 75 c.; ib., $\$ 2.50$.

\section{Peter Pan Pea}

A very promising new early sort with big dark green pods sort $F$ eas. See ancription. Plkt. 15c.; 1/2 lb.,

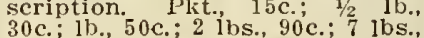
$\$ 2.50 ; 14$ lbs., $\$ 4.30$.

\section{Royal King Pepper}

Royal King is very thickmeated averaging about as thick again as the old Ruby King and others of the Beil type. It is perfectly sweet and free from pungency. It is a heavy bearer and a good shipper. One party says: "We have grown and shipped thousands of bushels of this pepper" in the past and could of ten make sales of it in markets that were glutted with other sorts." Plst., 15c.; 1/2 oz., $25 \mathrm{c}$.; oz, $45 \mathrm{c}$.;

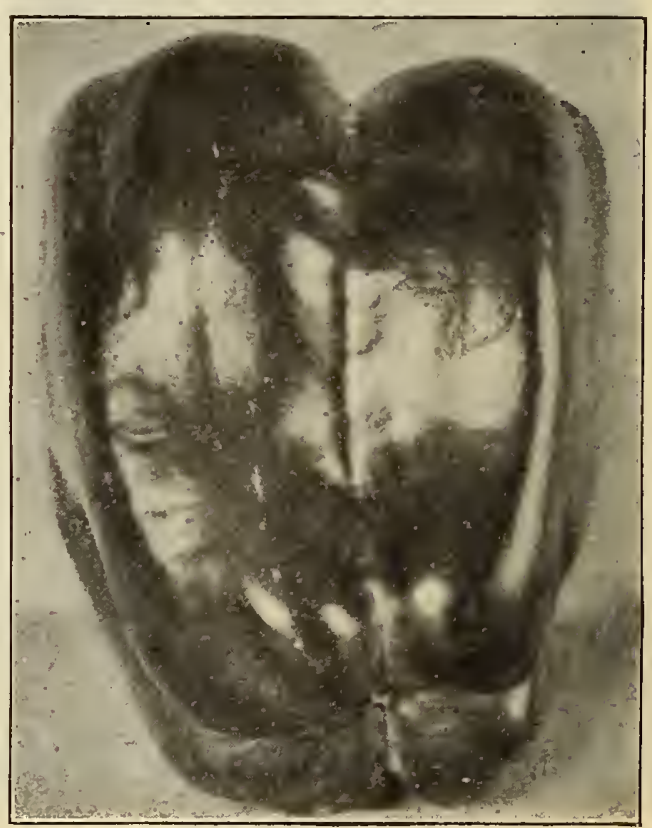

Royal King Pepper 


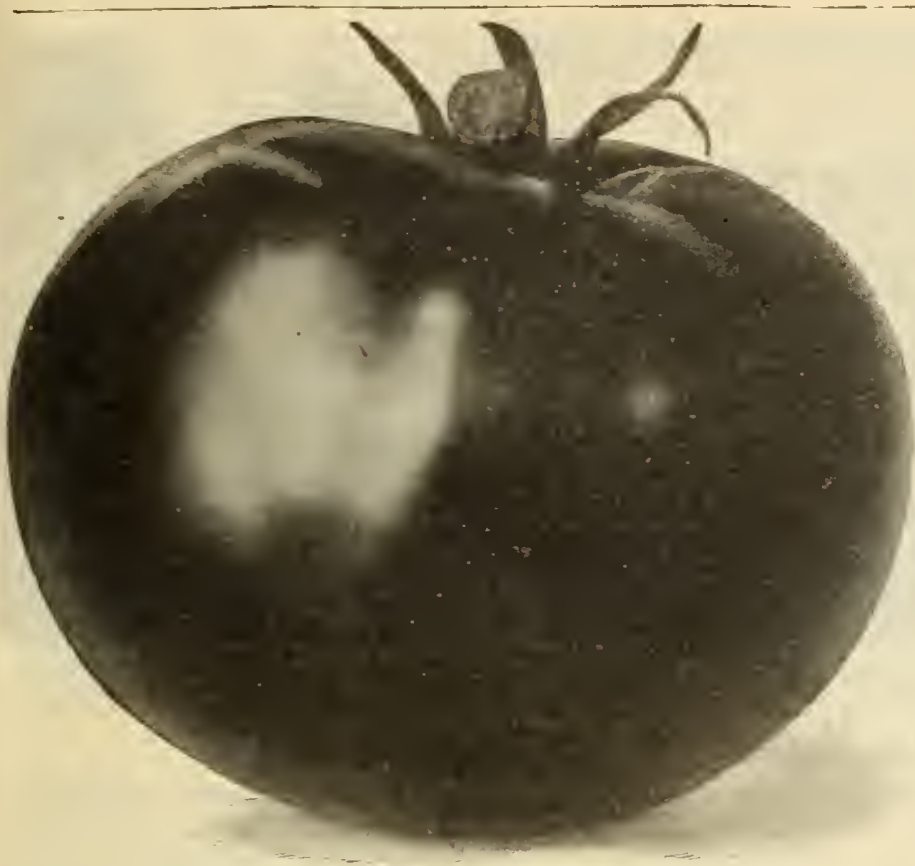

\section{New Tomato Livingston's Manyfold} Brightest Red Inside and Out-Earliest Big Red

Iivingston's Manyfold has a brilliant, bright recl fruit that averages almost equal in size to Livington's Stone, and fully as productive, if not more so, but begins bearing earlier, hence lengthening the bearing season when used along with the large and later sorts. The fruit is borne in large clus ters which generally average five or more to the most sorts and therefore is very productive. Almost invariably all of the fruits are of marketable size. Last season owing to unfavorable condiable size. Last season owing to unfarorable condiconditions were more favorable it came up fully to our description and claims. The flesh of the Livingston's Manyfold Tomato is one of the richest reds we have ever seen. Even the pulp surrounding the seed, in most specimens, shows the red coluring. We feel that this point of high color, together with the early maturity of a very large percentage of the crop, should appeal very strongly Canners and makers of catsuv, and equally so to priva users of Tomatoes.

Livingston's New Manyfold Tomato is the most promising of all recent introductions. We have faith in it, and know you will not regret using it nour crop for this season. Pkt., $15 \mathrm{c}$.; $1 / 4 \mathrm{Oz}$., 5

Mr. H. F. Tenney, Marion Co., Ill., writes: wish to state that one vine of your New Mlanyfold Tomatoes in my garden broke all records that I hare erel heard of. It ripened 65 marketable ToLivingston's Manyfold, Natural Size

A. G. Fisher, Lawrence Co., Ohio, writes, Feb. 6, 1918: "We planted Livingston's Manyfold Tomato last year and it was fully up to your claim for it.

Mr. Ferman Horwald, Ferkimer Co., N. Y., writes: "Your Manyfold Tomatoes are all you claim them to be"

\section{New Aster Heart of France}

1397-The best pure red Aster ever introduced. In any light, natural or artificial, Heart of France is startlingly beautiful and $\pi$ ill command instant admiration. The flowers are large and full with never a trace of hollow cente:. The plants are of branching type and very robust habit. The stems are long and strong and have very few laterals. The plants begin to bloom quite early in the season and open fully with the mid-season varieties. They retain their brilliancy and luster for a longer period than almost any other color. This will be a tip-top variety for florists as well as home gardeners for the reason that the flowers and stems are so large and vigorous and their shipping and longkeeping qualities are such as to make it a winner for almost any purpose. Pkt., 25c.

\section{New Aster Peerless Yellow}

1415-The best yellow Aster ever introduced. Every flower. will come a beautiful Chrysanthemum yellow and are renarkably full and ball-shaped with centers deeply covered with curled and twisted florets.

The plants are of the branching type and very vigorous. It is not unusual to find a plant witl from twenty to thirty good flowering stems sufficiently long and with flowers of ample size for fancy cut flower purposes. So numerous and large are the flowers that the plants are completely covered with a golden dome. Frequently visitors comment on its resemblance to a miniature yellow snowball. It is certainl a winner in its class and color. Pkt., 25c.

\section{Ex. Ea. Mammoth Cosmos}

1670-This is a new strain of Cosmos especially selected for size of flower and earliness. In this new strain we overcome what is very often a disappointment, in not getting flowers before frost. The growth of this new Cosmos is so rapid that seed can be sown out of doors where plants are to grow and within a few weeks the plants will be covered with a mass of large, beautiful flowers and will continue to bloom until frosts come in the Fall. This excellent strain will produce flowers equally as large and beautiful as the late flowering sorts. Mixed. Plit., $15 \mathrm{c}$; $1 / 4$ oz., $25 \mathrm{c}$; $\mathrm{Oz}_{.}, 75 \mathrm{c}$. matoes and 15 more good sized green ones were on the rine when frost came, making 80 marketable Tomatoes o one vine which was staked and pruned to three branches."

\section{Livingston's Mammoth White Centaurea}

1630 - This is one of the largest pure white Centaureas et introduced. The plants are of branching type and very robust habit, standing eighteen inches to two feet high. The plants begin to bloom quite early and continue until frost comes in the fall. The stems are sufficiently long for cut flower purposes. The flowers are snow white and of ten measure four inches or more in diameter. The long stems, large snow white flowers and keeping qualities are such as to make it an excellent flower for the florist as well as for the home garden. Plst., $15 \mathrm{c}$

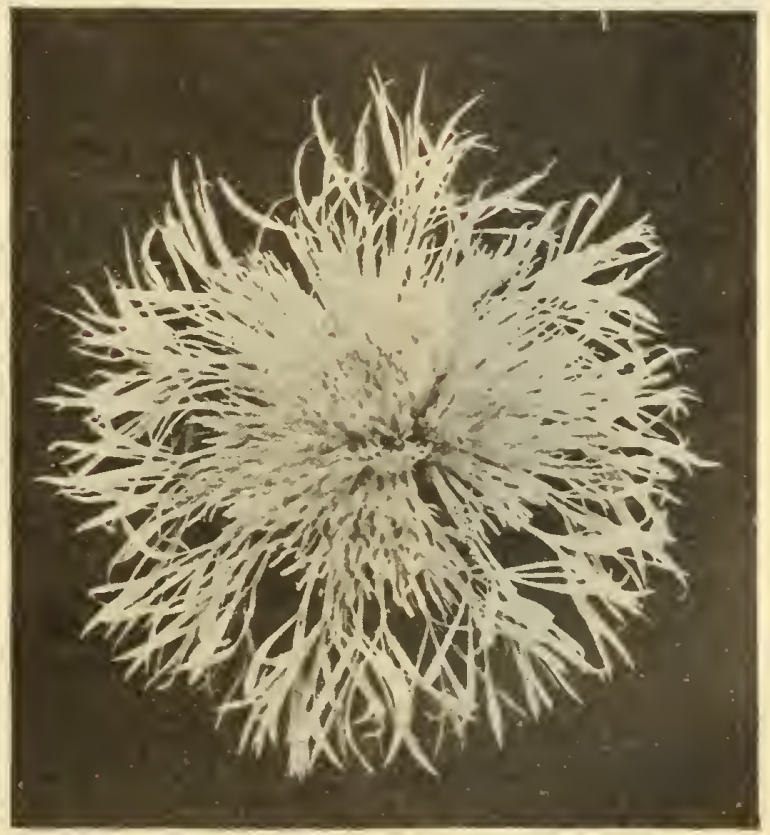

Mammotl White Centaurea 


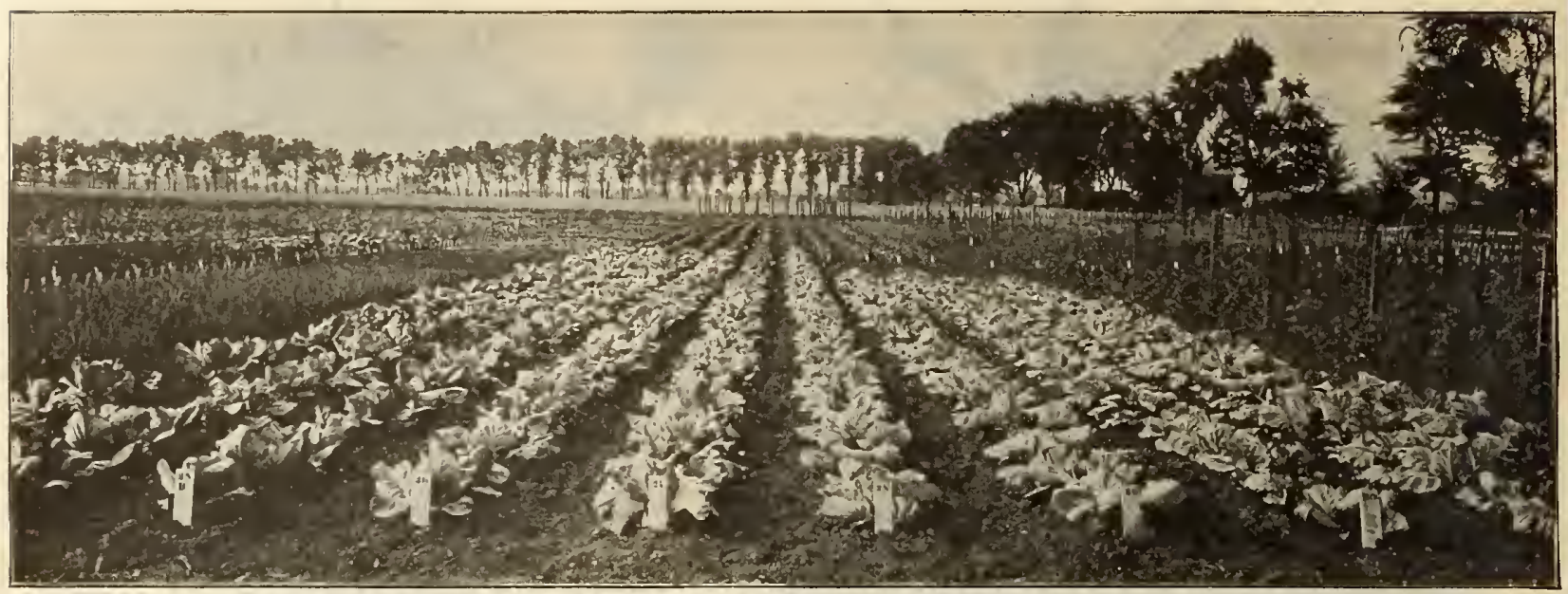

\section{Livingston's "True Blue" Vegetable Seeds}

In our Vegetable Seed Department we have listed only such varieties as are of real merit, having rigidly excluded all sorts that are not of value, and have cut out a number of out-of-date varieties.

similarity of variety, so as not to offer Cultural directions will be found at the heading of each class of vegetables, and also on most of our packets. These directions, while reliable, will not apply in every detail to the extreme sections of the United States, and therefore some allowance must be made for the difference in latitude.

We also send free to our customers, on application, a cultural leaflet- "The Vegetable Garden," which is of value to beginners.

\section{spargel Asparagus Esparragos}

It can be grown in any good garden soil, but does best $\mid$ the permanent bed. Set the plants one foot apart each in sunny, moist soil. To grow plants from seed, sow in drills about one inch deep in rows one foot apart. Keep the soil mellow and free from weeds: during the Summer thin out, and the following Spring plants may be set in well ten inches below the surface, spreading the roots wlant prows fill in the trench one ounce of son and as $60 \mathrm{feet}$ of drill. About 400 plants to the ounce. Ieaflet with Cultural directions free to customers.

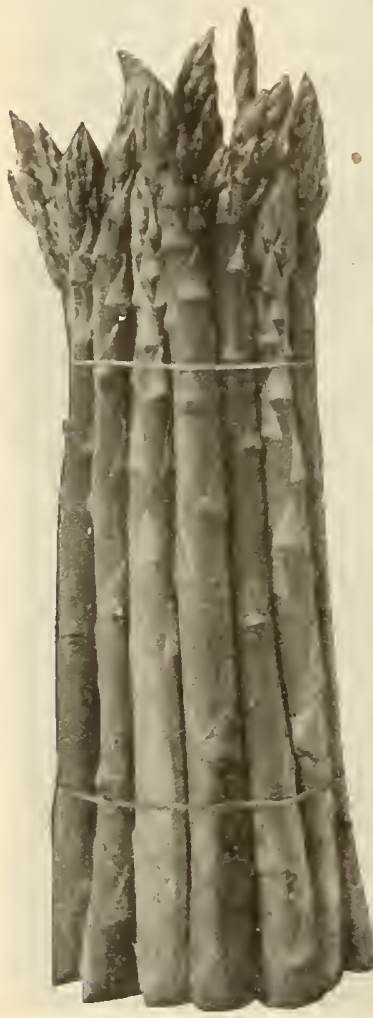

Palmetto Asparagus

Columbian Mammoth White-A distinct variety, producing shoots which are white and remain so long as fit for use. Vigorous and robust in habit; grows large shoots. Needs no earthing up. Pkt., 5c.; oz,, 10c.; $1 / 4$ lb., 25c.; 1b., 85c

Glant Eariy Argenteuil-A splendid early French variety of large size and green in color; excellent flavor. Pkt., 5c.; oz., 10c.; $1 / 4$ 1b., 30c.; lb., $\$ 1.00$

Palmetto-Large, dark green variety of vigorous growth, having pointed tips. Early. Pkt., 5c.; oz, $10 \mathrm{c} . ; 1 / 4$ lb., 25c.; 1b., $75 \mathrm{c}$.

Conover's Colossal-Large and rapid grower of excellent quality; color, green. Pkt., 5c.; oz., 10c.; $1 / 4$ lb., 25c.; lb., 75c.

\section{Broccoli}

Broculi

Spargelkohl

This plant is very closely allied to the Cauliflower, the variation being very slight. It is generally considered rather more hardy, however. In growing Broccoli, a seed bed should be prepared and the seed sown in May. The plants will be ready to transplant late in June or early in July, and should be set in very rich mellow ground, in rows about $2 \frac{1 / 2}{1}$ feet apart, leaving 18 inches between the plants.

Early Irayge White-Heads medium ize, close and compact. One of the most certain to head. Pkt., 10c.; oz., $30 \mathrm{c}$

Early Purple Cape-Rather hardier sort; greenish purnle heads; good favol, Plit., $15 \mathrm{c}$,

\section{Brussel Sprouts} Col de Bruselas

Rosenkoh1

A species of the Cabbage family, which produces miniature heads from the sides of the stalk. These heads are a great delicacy, boiled in the same way as Cauliflower. The seed should be shown about the middle of Nlay, in a seed bed, and the plants afterwards set in rows 2 feet or more apart, and cultivated like Cabbagc.

Improved Dwarf-Produces compact sprouts of the finest quality; a good keeper. Pkt., 5c.; oz., 30c.; 1/1 lb., 85c.; 1b., $\$ 3.00$.

Pride of Denmark-A fine new variety, growing about 3 feet tall. Sprouts develop along entire stock at onc time, lower ones being as good as those at top. Pkt., 10c.; oz., 35c.; $1 / 4$ lb.; $\$ 1.10$; 1b., \$3.75.

Borecole, or Kale-See Kale, page 24.

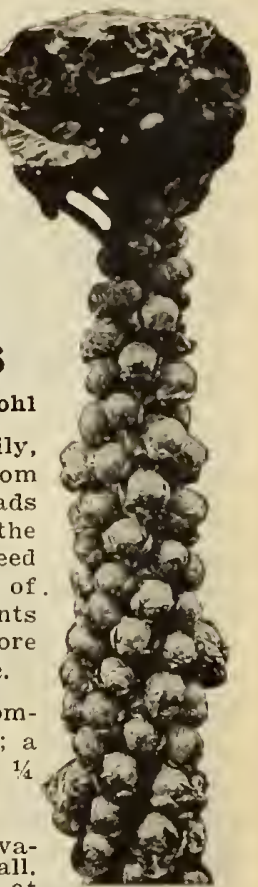

Pride of Denmart Brussels 


\title{
Livingston's Garden Beans
}

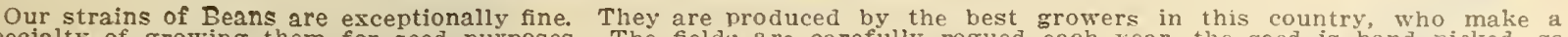

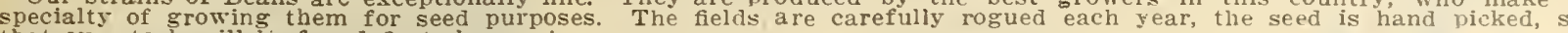
that our stock will be found first-class.

Bean Prices include postage, up to two pound quantities. If the larger quantities are wanted sent by mail it will be necessary to remit additional amount at the Parcel Post rates. Refer to page 3 for rates.

Two pounds (one quart) will plant 100 feet of drill; 1 to 2 bushels to the acre.

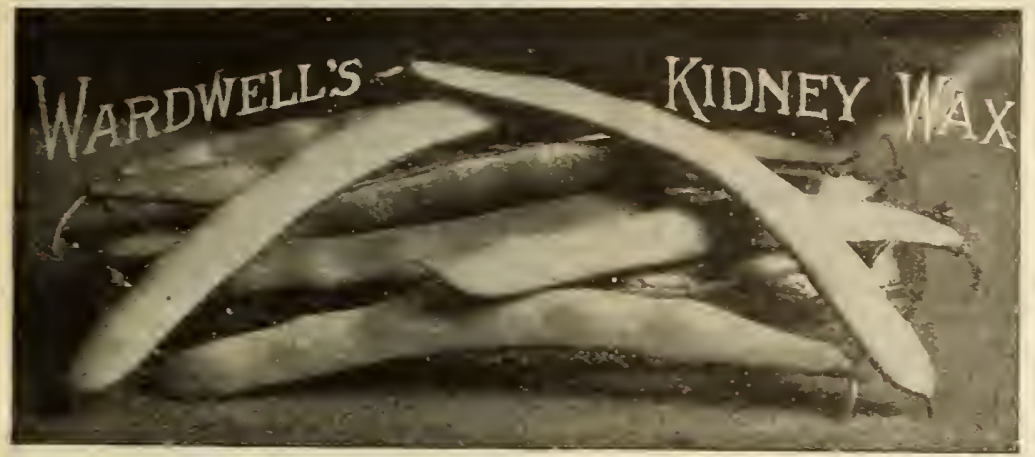

\section{Wax Podded Dwarf Varieties}

\author{
New Kidney Wax
}

\section{Wardwell's Kidney Wax}

Immensely productive, One of the rabdsomest Wax Podded Beans. Early; vine medium, erect, hardy, produc. tive. Pods long, broad, fat, brittle and of a delicate raxy yellow. Very attractive inarket sort. I'kt., 15c.; 1/2 lb., 25 c.; lb., 45 c.; 2 lbs., 80c. By express, not paid, 7 lbs., $\$ 1.90: 15$ lbs., $\$ 3.50$.

\section{Keeney's Rustless Golden Wax}

A strong grower; free from rust. Pods meaty ond well illed, semi-round, rich yellow, fine quality; entirely stringless. Pkt., 15c.; $1 / 2$ lb., 25c.; 1b., $40 \mathrm{c}$; 2 lbs., 70c. By express, not paid: $7 \mathrm{lbs}$., $\$ 1.75 ; 15 \mathrm{lbs} ., \$ 3.25$.

\section{Improved Golden Wax}

Grennell's-One of the best strains of Golden Wax. Hardy, prolific, of best quality; pods straight, thick, and vines erect Plst., 15c.: 1/2 1b., $25 \mathrm{c}$.; 1b., 40c.; 2 lbs., inc. By express, not paid: 7 lbs., $\$ 1.75 ; 15$ lbs., $\$ 3.25$.

\section{Davis White Wax}

Very productive, white-seeded, rustless, string or snap variety. A good variety for shipping. The dry white Beans are good for cooking purgoses. Plkt., 35c.; $1 / 2$ lb., 25c.; lb., 40c.; 2 lbs., 70c. By express, not paid 7 lbs., $\$ 1.75 ; 15$ lbs., $\$ 3.25$.

\section{Green Podded Dwarf Varieties}

\section{Giant Stringless Green Pod}

Has a much larger pod than Stringless Green Pod, or about one-third larger than the Valentine-average 5 inches long. Full and fleshy, extremely crisp and absolutely stringless; very early and prolific. Pkt., 15c.; 1/2 lb., 25c.; lb., 40c.; 2 Ibs., 70c. By express, not paid: 7 lbs., $\$ 1.65 ; 15$ lbs., $\$ 3.00 ; 60$ lbs., $\$ 11.00$.

\section{Stringless Green Refugee}

Planters everywhere will at once recognize the wonderful merit of this new Bean when it is stated that in addition to the superior qualities of the old Refugee or 1000 to 1 , this new sort is absolutely stringless. It has every quality desirable in a bush bean-true bush habit, 18 inches high, unusually productive. The pods are round, very fleshy, tender, brittle and entirely free from strings at all stages of growth. Pkt., $15 \mathrm{c} ; 1 / 21 \mathrm{~b} ., 25 \mathrm{c}$.; 1b., 40c.: 2 lbs. 70c. By express, not paid: 7 lbs., \$1.75; 15 lbs., \$3.25.

\section{All Prices in This Catalogue are Subject to Change} Without Notice 15 lbs., $\$ 3.15$.

\section{Livingston's Pencil Pod Wax}

Although hardy, it is stringless, tender and of tine quality. Pods smooth, perfectly round and straight. In points of vigor, hardiness and productiveness, it is superior to most sorts. Plit., 15c.; $1 / 2$ lb., $25 \mathrm{c}$; Jb., $40 \mathrm{c}$; 2 lbs., $70 \mathrm{c}$. By express, not paid: 7 lbs., $\$ 1.70 ; 15$ los., $\$ 3.15$.

\section{Improved Prolific Black Wax}

Pencil Pod Strain-Pods are long, lleshy, round, waxy yellow, solid and tender; very early. Pkt., 150.; 1' lb., 25c.; lb., 40c.; 2 lbs., 70c. By express, not paid: 7 lbs., $\$ 1.70$;

\section{Round Pod Kidney Wax}

Pods are round. Plants grow strong and sturdy, with long, round, handsome, stringless pods of large size, very solid and full of meat crisp, brittle. Wonderfully eurly and productive, and has becom very popular. Pkt., 15c.; 3. lb. 25c.; 1b., 40c.; 2 lbs., i0c. By express, not paid 7 lbs., $\$ 1.75 ; 15$ lbs., $\$ 3.25$.

Livingston's Hardy Wax - See Novelty pages.

Sure Crop Wax - See Novelty pages.

\section{Hopkin's Earliest Red Valentine}

One of the earliest and most prolific round green podded Beans. Comes into bearing earlier than the
Extra Early Valentines, is a wonExtra Early Valentines, is a won-
der. Remains in good condition a long time after picking. Plit., 15c.; $1 / 2$ lb., $25 \mathrm{c}$.; $1 \mathrm{b.,} 40 \mathrm{c}$.; 2 lbs., $\$ 1.65 ; 15$ lbs., $\$ 3.00$.

\section{Full Measure}

A very desilable round-podded variety with pods 6 to 7 inches long, which are solid, meaty brit stringless. It is a little later than Stringless Green
Pod and is a splendid Bean Pod and is a splendid Bean
for home or market use. Pkt., 15c.: 1/2 lb., 25c.: 1b., 40c.; 2 lbs., 70c. By express lbs., $\$ 2.85^{\circ}$.

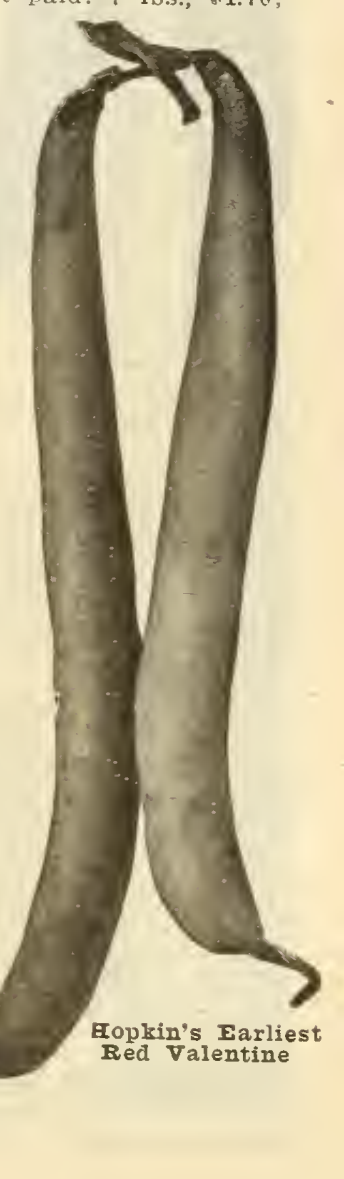




\title{
Green Podded Beans (Continued)
}

\author{
Prices of Beans Include Postage up to and Including 2 pounds
}

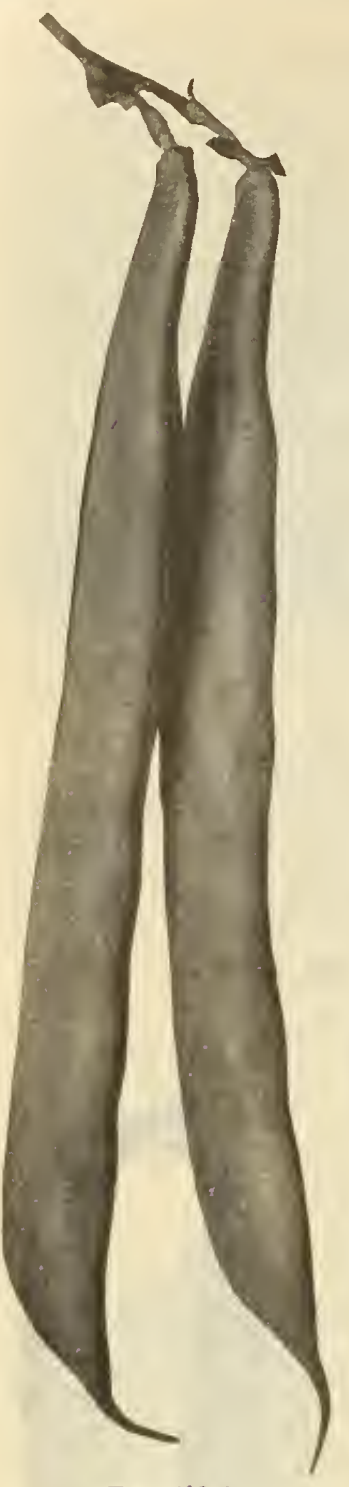

Bountifu1

\section{Bountiful}

(See illustration.) A green pod Bush Bean, which comes into bearing very early and continues throughout the season. Pods beautiful rich green, very thick, broad, long and uniform; meaty, tender, fine quality; absolutely stringless. Good shell Bean for Winter use. A splendid market variety. Pkt., 15c.; $1 / 2$ ib., $25 \mathrm{c}$.; 1b., 40c.; 2 lbs. $70 \mathrm{c}$. By express, not paid: 7 lbs., $\$ 1.65 ; 15$ ibs., $\$ 3.00 ; 60$ lbs., $\$ 11.00$.

\section{Livingston's Round Six Weeks}

Extra-early; strong grower and abundant cropper. Pods green, very fleshy, free from strings when young. Pkt., 15c.; $1 / 2$ lb., 20c.; lb., 35c. 2 lbs., 60c. By cxpress, not paid: lbs., $\$ 1.50 ; 15$ lbs., $\$ 2.75$.

Refugee or 1000-to-1-Fine quality, medium late. Prolific; nearly round. Our strain is extra fine. Pkt., 15c.; 1/2 lb., $25 \mathrm{c}$.; lb., $40 \mathrm{c}$.; lbs., $\$ 1.70$; 15 lbs., $\$ 3.15$; 60 lbs., $\$ 11.50$

Extra Early Refugee-Hardy an abundant bearer. Ten days earlier than Refugee or 1000 -to-1. Pkt., 15c.; 1/2 lb., 20c.; $1 \mathrm{~b} ., 35 \mathrm{c}$.; 2 $\$ 2.75 ; 60$ ibs., $\$ 10.00$

Tennessee Green Pod-This medium early sort is quite popular in some sections of the south. to 7 inches, flat and irregular in shape, of dark green color and is of exceptionally good quality. Pkt., 15c.; $1 / 2$ lb., 25c.; 1b., 40c.; ; lbs., $70 \mathrm{c} . ;$; lbs., $\$ 1.65 ; 1.5$ ibs.,

\section{Bush Lima Beans}

These varieties are of true Bush or Dwarf form, growing but 18 to 0 inches high, without supports. About two weeks earlier than the Pole Lima Beans. Sure croppers. Abundant bearers until frost. Plant in rows 2 to 3 feet apart and a foot apart in the rows.

\section{Burpee's Improved}

formly larger pods that Burpee's Bush Lima, while the pods contain more Beans, which are thicker and remain green even in the dry stage. The plants are very
prolific, bearing pods in clusters of from 5 to prolific, bealing pods in clusters of from 5 to long and contain from 5 to 7 Beans. The lightful flavor. They almost "melt in your mouth" to use a popular expression. Plit., mouth," to use a popular expression. press, not paid: 7 lbs., $\$ 2.20 ; 14$ lbs., $\$ 3.80$.

\section{Fordhook}

The Fordhook is entirely distinct in habit of growth. The stifly erect bushes branch freely and bear tremendous crops. It is ready for use as early as the popular Burpee's Bush remain green much longer. The shelled Beans are very fat, are closely packed in the pods, which shell very easily. Pods are borne in clusters of from 4 to 6 , average 4 to 5 inches long and contain usually 4 tender Beans of a delightful flavor. Pkt,, 15c.; 1/2 1b., 25c.; lb., $\$ 2.00 ; 14$ ibs., $\$ 3.70$. alog are subject to change without notice.
Dwarf Forticultural - Speckled Cranberry. Splendid for Shell 40c. 2 Pkt., 15c.; 1/2 1b., 25c.; 1b., paid: 7 lbs., $\$ 1.65 ; 15$ lbs., $\$ 3.00$; 60 lbs., $\$ 11.00$.

Improved Navy or Boston Pea Pean - Tery productive variety. . $1 / 2$ 1b., 25c.; lb., 35c.; 2 tity.

White Marrow-Good green or W Standard Soup Bean. Plkt., c. Write for prices in quantity. White Kidney, or Royal Dwarf-

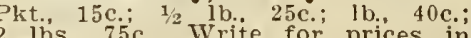
2 lbs., $75 c$. Write for prices in

in New Wonder or Quarter Century Pods about the same as Burpee's Bush Lima; Beans slightly smaller; a few days earlier and fully as productive. A sure cropper. Very true to bush form. An immense yielder. Plkt,, 15c.; 1/2 1b., 25c.; 1b., 40c.; 2 lbs., i0c. By express, not paid: 7 lbs., $\$ 1.80 ; 14$ lbs., $\$ 3.35$.

Burpee's Bush Iima-Bushes are of stout growth, branching so vigorously that each plant makes a large bush. Immense yielder of well-filled pods of large Beans of luscious flavol. Pkt., 15c.; 1/2 1b., 25c.; 1b., 40c.; 2 lbs., 70c. By express, not paid: 7 lbs., $\$ 1.80 ; 14$ lbs., $\$ 3.35$. form, and produces large crops. Delicious flavor. Beans are smaller than above sorts. Plkt., 15c.; 1/2 lb., 25c.; 1b., 45c.; 2 lbs., 85c. B! express, not paid: 7 lbs., $\$ 1.90 ; 14$ lbs., $\$ 3.50$.

Mrs. Malcolm E. Kates, Whitley Co., Ind.

Dear Sirs:

Received seeds from you yesterday in first class order. Many thanks for extras and your promptness. I always like to get your seeds for they are most sure to grow if weather is at all favorable. I have used your seeds several years myself, and my mother used to use them back in deal old Ohio years ago. I know they are good.
Henderson's Bush Iima-Compact bush

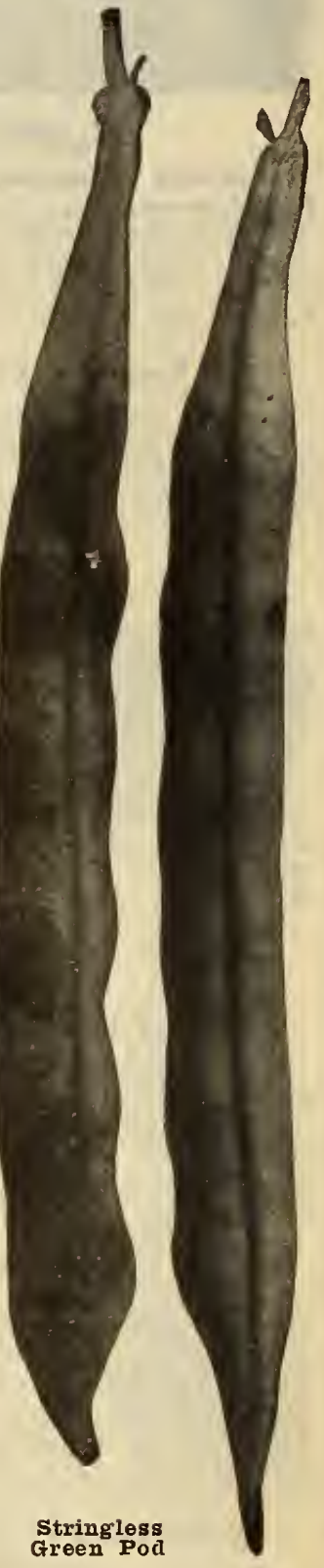




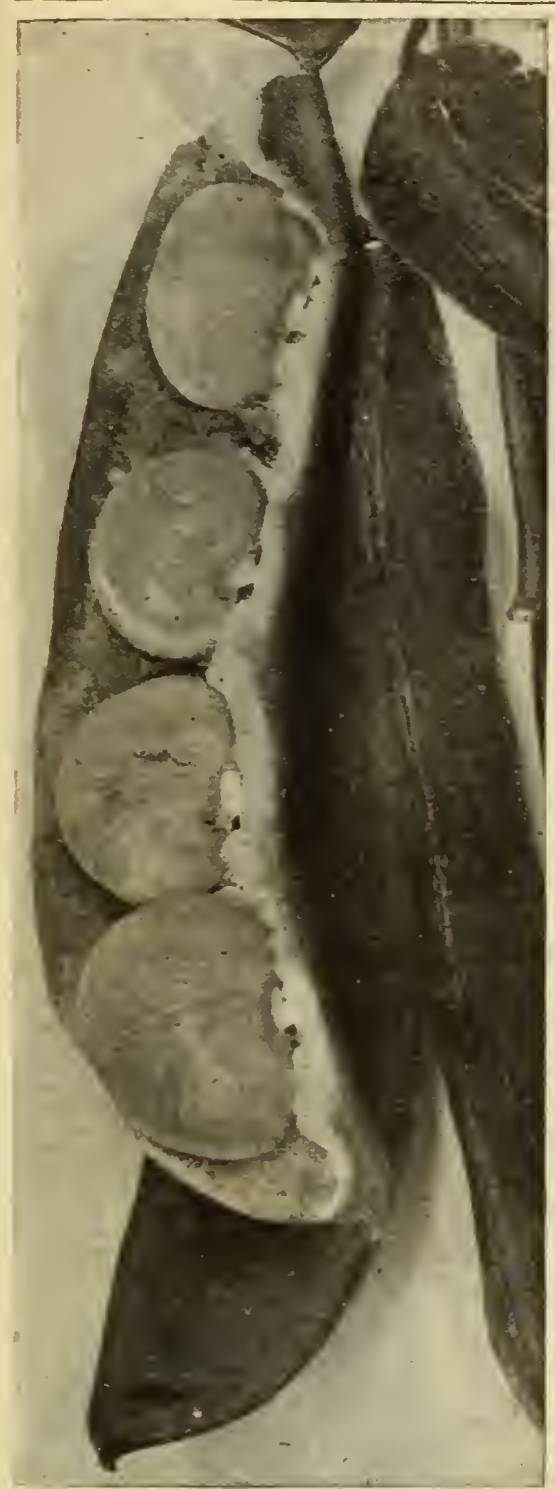

Carpenteria Iarge Green-Seed

\section{Pole Lima Beans}

Lima Beans will not grow untll the weather and ground are warm. If planted before, they are almost sure to rot in the ground. See cultural diing two pounds.

\section{Siebert's Early}

One of the very best fon market gardeners. The result of a number of years selecting to largest green Beans and easily opening pods. Very productive, hardy and vigorous. Produces pods early, and continues to the last ot the season. The green beans are of immense size, but so tender and succulent that they shrink in drying to about the size of the original White Lima. Pkt., 15c.; 1/2 Ib., 25 c.; 1b., 40 c.; 2 1bs., 70 c. By express, not paid: 7 lbs., $\$ 1.80 ; 14$ lbs. $\$ 3.35$.

\section{King of the Garden}

Vigorous grower, pods containing five to six large Beans, which are of fine quality. The vines grow strong and yield heavily. A very fine rariety. $\$ 1.80 ; 14$ ibs., $\$ 3.35$.

\section{Dreer's Improved}

Beans thick, sweet and tender; of medium size. Especially good for the

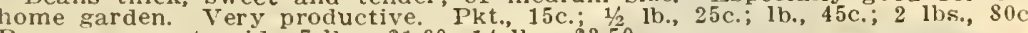
By express, not paid: 7 lbs., $\$ 1.90 ; 141 \mathrm{bs}$., $\$ 3.50$.

\section{Sieva, or Small Lima}

Early, and the small Beans are of luscious flavor. Fine sort for the kitchen garden. Pkt., $15 \mathrm{c}$.; $1 / 2$ lb., $25 \mathrm{c}$; lib., $40 \mathrm{c}$ 2 lbs., 70c. By express, not paid:' 7 lbs., $\$ 1.65 ; 14$ ibs., $\$ 3.00$

\section{Early Leviathan}

of superior quality. Wonderfully productive. The idea Pole Lima. Earliness is often obtained at the sacrifice of ther valuable features, but in this variety we claim superiority not only in this respect, but in size of Bean and pod and enormous productiveness. Pkt., 15c.; $1 / 2$ 1b., $25 \mathrm{c}$; $1 \mathrm{~b}$., 40c.: 2 lbs., $70 \mathrm{c}$. By express, not paid: 7 lbs., $\$ 1.80 ; 14$ lbs. $\$ 3.35$.

\section{Carpenteria Large Green-Seed (See Illustration)}

An excellent variety with many unique characteristics. Vines are strong, vigorous growth, setting many pods which are closely filled with large fat Beans, much thicker than those of the ordinary Pole Limas Pods contain 3 to 4 Beans, which retain the green tint in the dry statc-a sure indication of fine quality. Pkt., $15 \mathrm{c}$.; $1 / 21 \mathrm{lb} .25 \mathrm{c}$. ; $1 \mathrm{~b} ., 40 \mathrm{c}$. .

Fred V. Goeglein, Allen Co., Ind., on April 3rd, writes as follows: "I was more than pleased with the seed that I received from you last year. Every seed that I planted grew."

Jas. F. Knoop, Miami Connty, Ohio, writes: "The seeds I bought of you last year were all O. $K$, and I am going to buy or rou every rear.'

\section{Pole or Running Beans}

The Pole or Running varieties are tender and should be sown two weeks later than Bush Beans. They succeed best in sandy loam, which should be liberally enriched with manure. Two pounds will make 100 to 200 hills, according to size of Beans.

\section{Kentucky Wonder or Old Homestead}

in old favorite, with long, fleshy, deeply saddle-backed pods. Very prolific producing an abundance of fine, stringless, crisp pods until late in the season. Of best quality. Pkt., $15 \mathrm{c}$. paid: 7 lbs., $\$ 1.80 ; 15$ lbs., $\$ 3.35$.

Early Golden Cluster Wax-Splendid Snap Bean. Vines strong and hardy; very early and Bean. Vines strong and hardy; very early and vellow, stringless and tender. Pkt., $15 \mathrm{c}$.; $1 / 2 \mathrm{lb}$. $30 \mathrm{c}$; 1b., $50 \mathrm{c} . ; 2$ lbs., 90c. By express, not paid: 7 lbs., $\$ 2.40$; 15 lbs., $\$ 4.20$.

James E. Ice, Wetzel Connty, w. Va., writes: "Your seed just recently received and will state without exception, are the finest lot of seed I have ever seen. Am enclosing another order. Thanking you for your promptness."

\section{Kentucky Wonder Wax \\ (See Illustration)}

Quite similar to the Kentucky Wonder or Homestead Green Pod except in the color of nods. which in this one are light waxy yellow It has which in this one are light waxy yellow It has a thick, broad pod, very ender, of delicious flavor and 8 to 9 inches. It begins bearing when the vines are only a few feet in height, hence its earliness, and, therfore, a sort well adapted to maturing a crop where seasons are quite short. Pkt., 15c.; 1/2 1b., 25c.; 1b., $45 \mathrm{c}$; 2 lbs., 8 c.; 7 lbs. $\$ 1.90 ; 14$ Ibs., $\$ 3.50$.

Iazy wife-Pods 6 to 8 inches long, quite stringless: a good white Shell Bean for vinter. Pkt., 15c.; 1/ lb., 25c.; lb. 45c.; 2 lbs. 80c. By" express, not paid: 7 lbs., $\$ 1.90 ; 15$ lbs., $\$ 3.50$.

Speckled Cranberry-0ld "Bird Erg." Fkt. 15c.; $1 /$ lb. 25c.; 1b. 40c. 2 lbs., 70 c By express not paid: 7 lbs., $\$ 1.65 ; 15$ lbs., $\$ 3.00$.

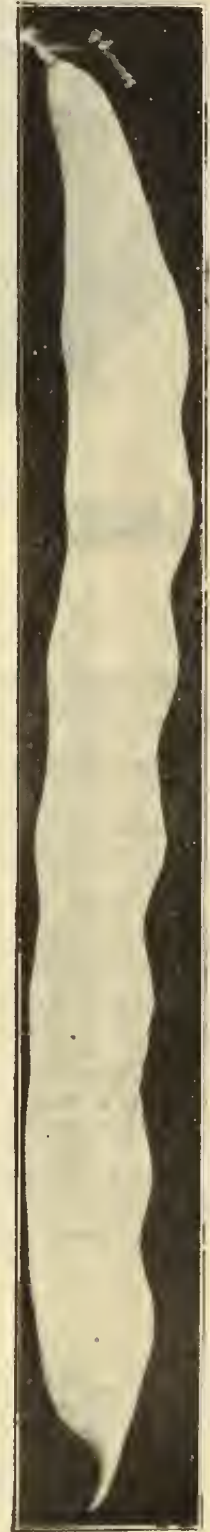

Ky. Wonder Wax 


\section{Garden Beets for Table Use}

Beets are one of our specialties and we grow acres of them for seed at our Kirkersville farms, first growing the roots from seed; holding these over and then making careful selection of the roots in the Spring, when ready to plant. This enables us to ffer a very superior strain of Beet seed.

The soil best suited for the culture of the Beet is that which is rather light, provided it is thoroughly mixed with manure. If wanted very early, sow in hotbeds and transplant; but for main crop sow in the Spring, as soon as the ground becomes fit to work, in drills 18 inches apart, 1/2 inch deep. For Winter use, the Turnip varieties may be sown as late as June and the seed covered two inches. When the plants ars 3 to 4 inches in height thin out so that they stand 3 or 4 inches apart. Keep free from weeds by frequent so that they stan hoeing and hand-weeding if llecessary. Before freezing weather sets in the roots may be stored in cellars or pits, same as potatoes; dry earth thrown not bruise them in handling. not bruise them in handling. One ounce of seed will sow 50 feet of drill;
5 to 6 pounds to the acre.

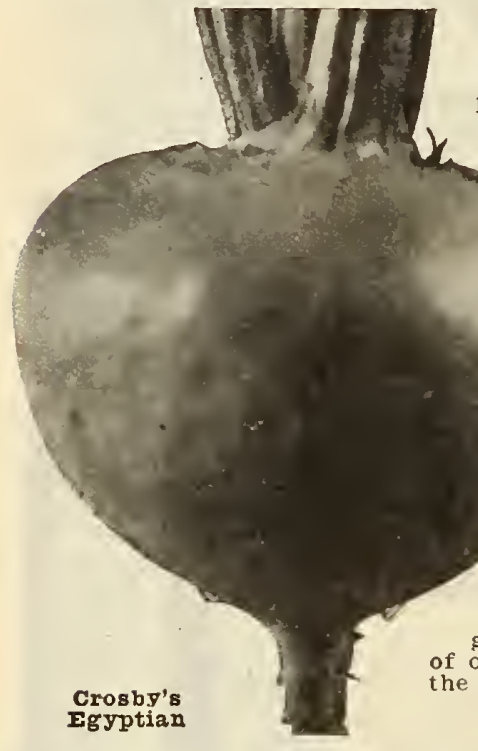

\section{Detroit Dark Red}

This superb variety is one of the most popular red Turnip Beets, not only for market gardeners, but for home use. It is also one of the best for canning, making a strikingly handsome product, far superior to that obtained from any other variety. The small top, early maturing and splendid shape and color have made it a favorite. Top small, upright growing, so that the rows may be close together; leaf, stem and vines dark red, blade green: root globular and very smooth isee illustration): color of skin dark blood red. flesh deep, bright red, zones with a darker

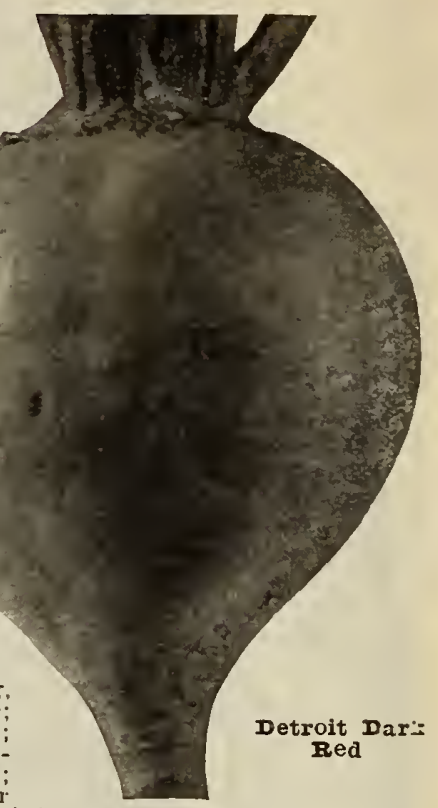
shade, very crisp, tender and sweet, remaining so for a long time. Very uniform in shape, color and quality. Pkt., 5c.; oz., 15c.; $1 / 4$ lb., 45 c.; lb., $\$ 1.50$.

\section{Crosby's Improved Egyptian Beet}

A rery superior beet. Of handsome form, good size, few small tops, very small tap root, fine quality and a rapid grower. The shape is very desirable not quite so round as the Eclipse. (See illustration.) Takes on its turnil) shape and looks well in the very early stages of its growth, on which account it is preferred for first early crop to the Globe and Half-Long varieties. Being a rapid grower, it may be sown outside as late as July. We have made a very fine selection our stock for years and we believe have it nearer the original crosby idea than any in trade. Pke.. 5c.; 0z., 15c.; 1/4 lb., 45 c.; 1b., $\$ 1.50$.

\section{Early Eclipse}

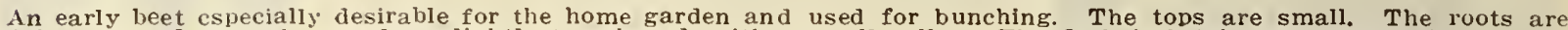

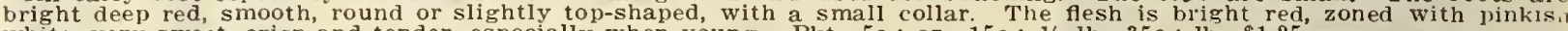
white, very sweet, crisp and tender, especially when young. Pkt., 5c.; oz., 15c.; 1/4 Ib., $35 \mathrm{c}$.; Ib., $\$ 1.25$.

Dewing's Improved Blood Turnip-The leading main crop variety. Roots always smooth, handsome, good size, tender and sweet. An enormous cropper. A favorite with marketmen. Pkt., 5c.; oz., 15c.; 1/4 1b., 35 c.; 1b., $\$ 1.25$.

Extra-Early Dark Red Egyptian-Very early, dark blood red, medium size, tender and weet; fine for kitchen gardens. Pkt., 5c.; oz., $15 \mathrm{c}$.; $1 / 21 \mathrm{~b} ., 45 \mathrm{c}$.; Ib., $\$ 1.40$.

Bastain's Early Blood Turnip-The largest of the turnip-shaped Beets. Tender and sweet. The flesh is somewhat lighter in color than other sorts. Pkt., $5 \mathrm{c}$.; oz., $20 \mathrm{c}$.; $1 / 4$ lb., $65 \mathrm{c}$.; Ib., $\$ 2.00$.

Fdmand's Blood Turnip-Very uniform, Root is always smooth, round and handsome; top small; of good marketable size and among the best for table use. Color dark red; crisp, tender and sweet; good keeper. Pkt., 5c.; oz., 15c.; 1/4 1b., 45c.; lb., \$1.40.

Crimson Globe-Root of medium size, very handsome, globe shape and has a remarkably smooth surface. Both the skin and flesh are deep, rich red, fine grained, sweet and tender in all stages of growth. Small tap root: leaves are small, dark green. Pkt., 5 c.; oz., 20c.; $1 / 4$ 1b., 65 c.; 1b., $\$ 2.00$.

Ientz's Early Blood Turnip-A great favorite with market gardeners around New York and Philadelphia Of a rapid growth fine form, exceedingly sweet and delicious. Pkt., 5c.; oz., 15c.; 1/4 Ib., 35c.; Ib., \$1.25.

Half-Iong Blood Red-Of handsome shape, fine quality, quick growth. good for Winter use if planted late. Pkt., 5c.; oz., 15c.; 1/4 lb., 35c.; 1b., \$1.25.

Iong Dark Blood Red-A good keeper of good size, flesh dark blood red. Pkt, 5c: oz, 15c: 1/1 lb, 35c:; lb., \$1.25.

\section{Swiss Chard or Spinach Beet}

A peculiar variety of Beet, of which the leaves only are used. It does not make a large root, but the leaves are splendid "greens" when cut young, and are equally delicious when allowed to mature. The broad, white leaf-stalks or mid-ribs are cooked and served like Asparagus. Produces continually from July until Fall. Can be had throughout the Summer when Spinach cannot be grown.

Silver, or Sea Zale-Yellowish green in color. Pkt., 5c.; oz., 15c.; 1/4 1b.. 45c.; 1b., \$1.50.

Incullus-An improvement over the common variety. The plants grow from 2 to $21 / 3$ feet tall and consist, when fully developed, of about a dozen creamy white, attractively curled leaves. These leaves are carried on broad, thick stalks, about 12 inches long. Plkt, 5c.; oz $15 c ; 1 /$ lb $50 \mathrm{c}$. Ib. $\$ 1.75$. 


\section{Beets for Stock Feeding}

\section{Mangel - Wurzels}

An ever-increasing acreage is being planted to stoci Beets, because of the wonderful results from feeding them. Sow in rows $2 \frac{1 / 2}{}$ to 3 feet apart as soon as the ground can be thoroughly worked. Cover seed about 1 inch, making ground firm over the seed. When 4 inches high, thin to 8 inches apart.

beets cannot stand being frozen, so should be harvested before cold weather sets in, and they may be buried in pits the same as potatoes or turnips, when roots are thoroughly dry: Six pounds sow one acre.

\section{Mammoth Long Red}

Also called Norbiton Giant, Jumbo Mangel, Colossa1, etc. -A favorite with the farmer and dairyman; large, wellPkt., 5c.: oz., 10c.; $1 / 4$ lb., $25 \mathrm{c}$.; 1b., $75 \mathrm{c}$.; 5 lbs., $\$ 2.50 ; 10$ lbs., $\$ 4.50$.

\section{Golden Tankard}

Very productive and sweet; flesh yellow; tops and neck very small; easily pulled. Especially relished by sheep and cows. Pkt., 5c.; 0z., 10c.; $1 / 4$ 1b., 25c.; 1b., 75c.; 5 lbs. $\$ 2.50 ; 10$ ibs., $\$ 4.50$.

Yellow, or Orange Globe

Tery productive; easily pulled; fine keeper; spherical shape; orange-yellow color. Pkt., 5c.; oz., 10c.; $1 / 4$ lb., 30c.; lb., $\$ 1.00$.

\section{Golden Giant Intermediate}

Yellow Ieviathan, or Mammoth Yellow-Beautiful russet yellow; skin smooth; fiesh white, firm, sweet; productive; easily pulled; good keeper. Pkt., 5c.; oz., 10c.; 1/4 lb., $25 \mathrm{c}$; $1 \mathrm{~b} ., 85 \mathrm{c}$.

\section{Gol repollo

Cabbage requires deep, rich, mellow soil, high manuring and good culture to obtain fine, solid heads. For early use, sow seeds of the early kinds in the hot-beds or in a box in the house the last of January or early in February; transplant into the open ground in April in rows feet apart and For second early Cabbage, sow in April and transplant in May. For late Cabbage. sow in May and transplant in July in rows 3 feet apart and 2 feet in the row. In transplanting, it is important that plants be set aown to the first leaf, so that the stem may not be injured in ease of frost. Be careful not to cover the heart of the plant Hoe every week and stir soil deep As they advance in growth draw a little earth to the plants until they begin to head. To prevent splitting or bursting, go frequently over the ground and push every Cabbage that appears about to mature over sideways, which will break some of the roots and check its growth. To prevent attacks of the cabbage fiy on small plants, dust thoroughly with plaster, air-slacked lime or wood ashes. For cabbage worm, try Hammond's Slug Shot. One ounce of seed produces about 2500 plants. Four ounces will grow enough plants to set an acre,

Chinese Cabbage (Pe Tsai), Celery-Cabbage, Odorless Cabbage, etc., see novelty page.

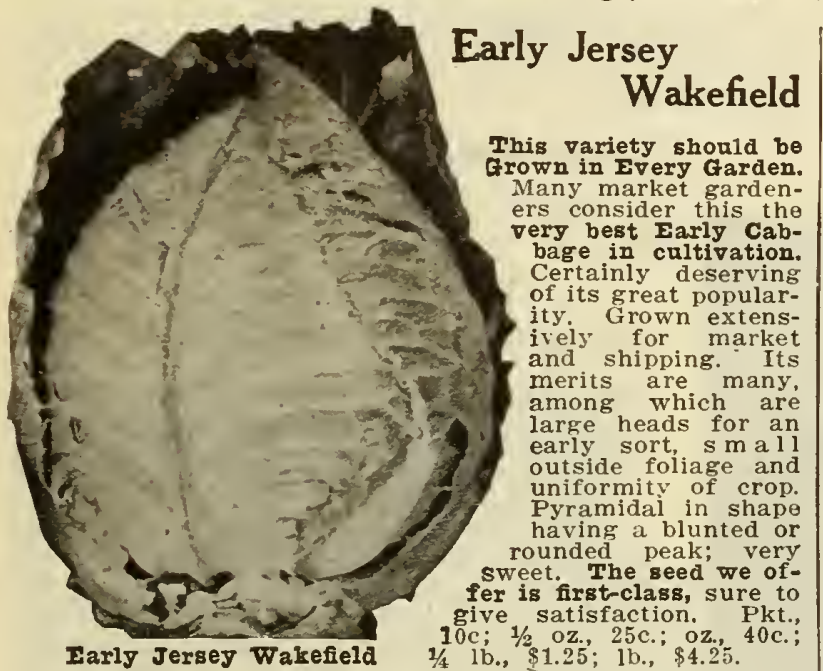

Large Charleston Wakefield

A selection from Early Jersey Wakefield, only it is about one week later than that popular early variety and grows much larger heads, often weighing 8 to 10 pounds. As solid as Early Winningstadt. There are immense quanti$1 / 2$ oz., 20c.: oz., 35c,; 1/4 lb., \$1.15; 1b., \$4.00.

\section{Fottler's Short-Stem Brunswick}

Rapid Grower; large, solid heads, few outside leaves; planted early, is ready for use in July; planted late, is a choice winter sort. Pkt., 10c.; $1 / 2$ oz., 20c.; 0z., 30c.; $1 / 4$ lb., $\$ 1.00 ; 1 \mathrm{~b}$., $\$ 3.50$.

\section{Copenhagen Market}

A splendid new extra-early round-headed sort which matures as early as the Wakefields and is or much larger size. Each plant forms a perfect, tightly folded head. averaging five to eight pounds in weight and about eight inches in diameter each way. The compact growth of the plant, the solidity of the head, its excellent flavor, and exone of the most meritorious Cabbages that have come to our notice in a decade. See specialty pages also. Pkt., 10c.; $1 / 2$ oz., 25 c.; oz., 45 c.; $1 / 4$ lb., $\$ 1.40 ; 1 \mathrm{~b} ., \$ 5.00$.

\section{Eureka First-Early}

In comparison with Early Jersey Wakefield Eureka, First Early is heavier, hardier, earlier, and has flat head. Forms head fit for market 5 days earlier than Early Jersey Wakefield. Its shape and excellent table qualities makes it favorite with consumers. Pkt., 10c.; $1 / 2$ oz., $25 \mathrm{c}$; oz., $40 \mathrm{c}$. $1 / 4$ lb., $\$ 1.30$; 1b., $\$ 4.50$.

\section{Early Spring}

As early as Early Jersey Wakefield. Will yield onethird more than any other extra-early Cabbage on sam area. Plant 21 inches a part and you have 13,000 per acre Has the peculiarity of heading firmly even before fully grown. Also flat-headed, making it valuable for extraearly market or home use. Pkt., 10c.; $1 / 20 z ., 20 \mathrm{c}$; $0 \mathrm{z} ., 35 \mathrm{c}$. $1 / 4$ lb., $\$ 1.15 ; 1 \mathrm{~b} ., \$ 4.00$.

\section{Early Winningstadt}

(The Old Standby)-WVell known and populay Cabbage. In season very close to Early Jersey Wakefield. Head large, decidedly conical. Solid, even in summer; slmos worm-proof, because so hard. A very sure header. Plit. $10 \mathrm{c}$; ; $1 / 2$ oz., 20c.; oz., 30c.; 1/4 1b., \$1.00.; 1b., $\$ 3.50$.

\section{Early Dwarf Flat Dutch}

Excellent second early variety; producing fine, large heads. Highly valued for its quality and ability to resist heat. Heads very solid, broad, round, flattened on top, tender and fine-grained. Pkt., 10c.; 1/2 oz., 20c.; oz., 35c.; $1 / 4$ lb., $\$ 1.15$; $1 \mathrm{~b}$. $\$ 4.00$. 


\section{Cabbage (Continued)}

\section{Surehead}

One of the most reliable main crop or late cabbages for northern latitudes, being very hardy and exceptionally sure heading. In some sections this is used largely as a late home market cabbage and for shipping. The plants are rather upright, with many outer leaves which are waved, thin edged, crimped and distinctly frilled; stem rather short. The heads are large and broad, thick, somewhat flattened, compact, very solid and of excellent quality. Pkt., 10c.; 1/2 oz., 20c.; oz., 35c.; 1//2 lb., $\$ 1.15 ; 1 \mathrm{~b} ., \$ 4.00$.

\section{All Season (Vandergaw)}

Greatly improved strain of Early Dwarf Flat Dutch. A very desirable large cabbage of intermediate season, adapted for a utumn as well as late summer use, and considered one of the most desirable for kraut. The plants ale very vigorous and sure heading, with few outer leaves which are large and fairly smooth or slightly waved. The heads are nearly round or somewhat flattened, very solid to stand the hot sun and dry weather, remaining an exceptionally long time in condition for use. Pkt., 10c.; 1/2 oz., 20c.; oz., 35c.; 1/4 lb., \$1.15; lb., \$4.00.

\section{Glory of Enkhousen}

It is very early and large, always extremely solid and fine ribbed-more so than any. other kind. Once known, it will hold its own with the market gardeners and home growers alike. In our judgment it excels in flavor all varieties known to us. It is an exceedingly tender, fine grained, and as a cropper no early Cabbage will approach it. Planted side by side with Early Jersey Wakefield, unmarketable size five to six days earlier, and in size fully double that of the Early Jersey Wakefield. Glory of Enkhousen Cabbage is more solid and better flavored and keeps in fine condition much longer. It is very dwarf and compact, allowing of close planting. Heads fine, ball-shaped, and with few outside leaves. Size ideal for marketing. An extra good cropper on account of extra size over many. other first early sorts. Plit., $10 \mathrm{c}$; ; $1 / 2$ oz., $25 \mathrm{c}$.; oz., $45 \mathrm{c}$; ; $1 / 4$ lb., $\$ 1.50$; 1 b., $\$ 5.50$.

\section{Louisville Drumhead}

About Cincinnati and Louisville it has been grown for more than 40 years. Heads very large and solid; a sure header; will stand without bursting almost the entire Summer. For Winter use, sow late in the season. Pkt., 10c.; $1 / 2$ oz., 20c.; oz., 35c.; $1 / 4$ lb., $\$ 1.15 ; 1 b ., \$ 4.00$.

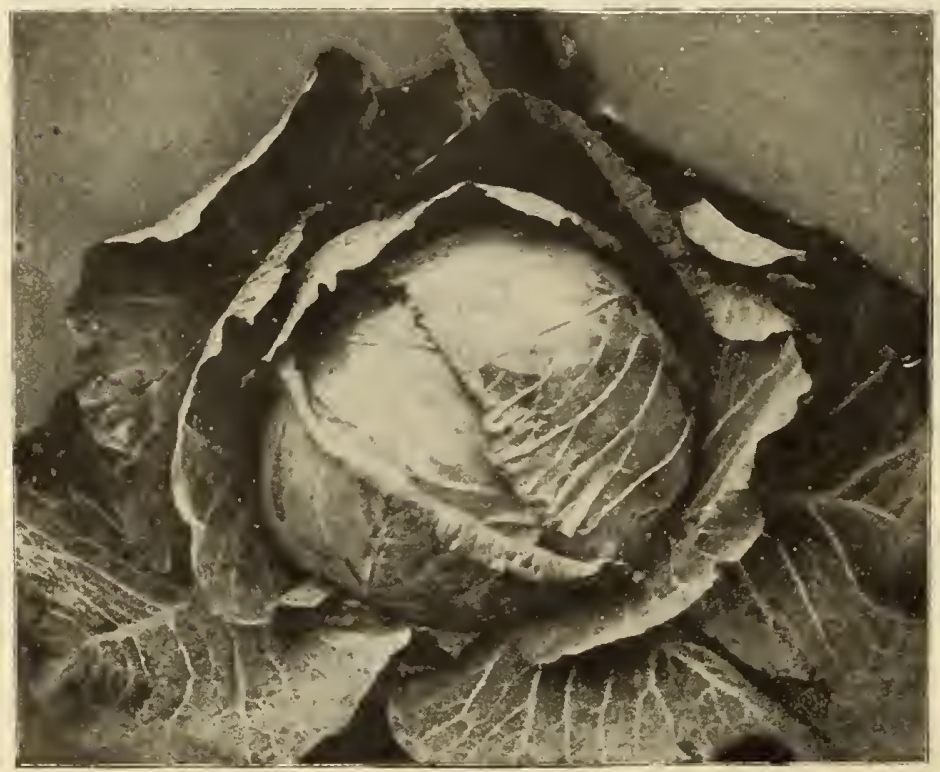

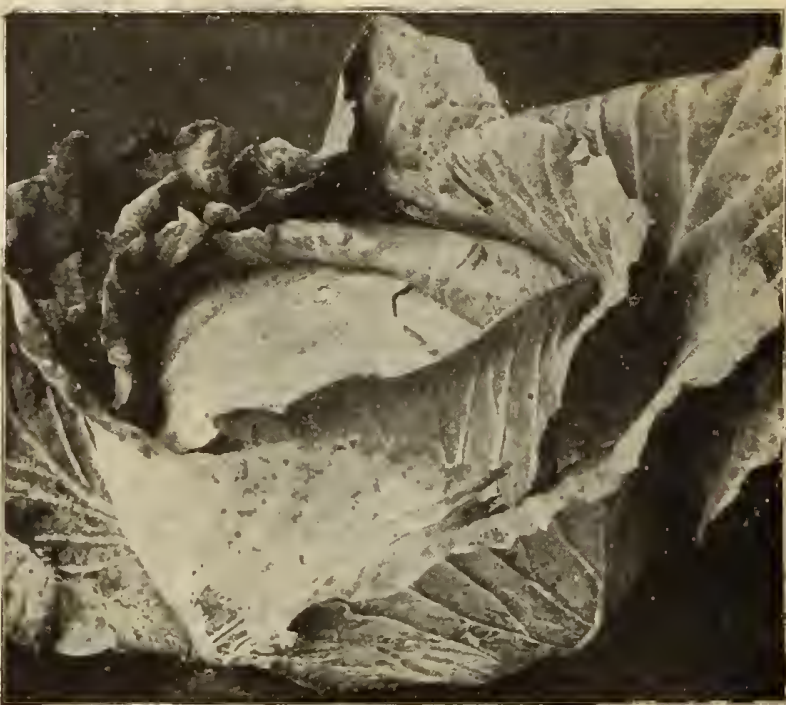

Henderson's Early Summer

\section{Henderson's Early Summer}

About 10 days later than the Early Jersey Wakefield, but; being fully double the size, may be classed with best large Early Cabbages. Equal in weight to most of late varieties: may be planted nearly as close as Early Jersey Wakefield. Keeps long time without bursting. Heads round. Plit., $10 \mathrm{c}$.; $1 / 2$ oz., $20 \mathrm{c}$; $0 \mathrm{z}$., $30 \mathrm{c}$.; $1 / 4 \mathrm{~b}$., $\$ 1.00$; lb., $\$ 3.50$.

\section{Autumn King or Wold Beater}

One of the finest strains of late Cabbage. It produces regular, even heads of enormous size; a great cropper on account of few outside leaves. Plit., 10c.; $1 / 2$ oz., 20c.; oz., $35 \mathrm{c}$; $1 / 4$ lb., $\$ 1.15 ; 1 \mathrm{~b} ., \$ 4.00$.

\section{Succession}

About one week later than the Henderson's Early Summer, but nearly double the size, while it can be planted nearly as close, its outer leaves being unusually short. $1 \mathrm{c}$ $\$ 1.15 ; 16 ., \$ 4.00$.

\section{Large American Drumhead}

A superior Fall and Winter variety; large heads. Pkt., 10c.; 1/2 0z., 20c.; 0z., 30c.; 1/4 1b., \$1.00; lb., $\$ 3.50$.

\section{The Volga (No. 20)}

This variety is of the greatest uniformity. In a field of severai acres frequently not a singlc plant shows any variation from a true and valuable type. In some respects it is a vegetable wonder, as the heads are about equal in size and shape, weighing from 12 to 15 pounds each, round as a ball, the largest measuring about 12 inches in diameter either way. Unlike most varietics, the heads are perfectly solid, and the stem does not run up into the head; the flesh is exceedingly firm, tender and white. In respect to hardiness we have never seen a type which would favorably compare with it. This type will mature its head fully two weeks earlier than any of our late growing kinds. Pkt., 10c.; $1 / 2$ oz., 25c.; oz., $40 \mathrm{c}$; $1 / 2$ lb., $\$ 1.30 ; 1 \mathrm{~b}$., $\$ 4.50$.

\section{All-Head Early}

A thoroughbred sort of remarkably uniform size and shape and sure heading qualities. Deep, flat heads, solid and uniform in color, shape and size. In tenderness unsurpassed. For Winte use, sow in July. By reason of its compactness 1000 more heads can be obtained from an acre than any other good-sized varieties. Pkt., 10c.; 

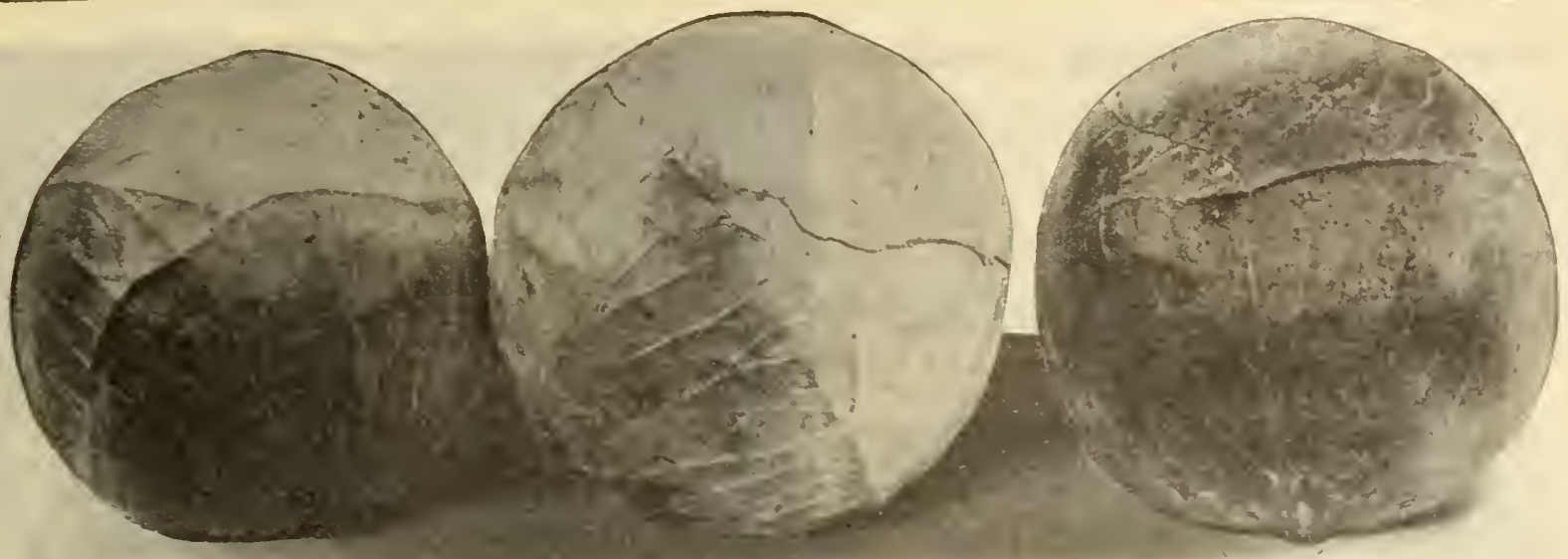

Danish Ball Head (Slort Stem)

\section{Danish Ball Head}

Tall Stem This splendid rariety is rell knwwn fur it.. ities. So remarkable solidity and grand kceping qualCabbage for this fine-grained sort as to render its importation from Denmark a most profitable enterprise for the vegetable dealer. The heads are very hear and superl in quality. The extra weight, in limited space, will be apin qualit or the exera weight, in limited space, will be appreciated by those who grow for distant markets, ship in car loads and sell by" weight. This variety" has been sol," "German Export." "Dutch Winter," etc., but the correct name is "Danish Ball-Head." Plit., $10 \mathrm{c}$.: 1/, 0\%, 20c.; oz., $35 \mathrm{c}$ : $1 / 4$ lb., $\$ 1.10$; lb., $\$ 3.75$.

\section{Short Stem}

\section{Danish Ball Head}

has shorter stem. Less outer foliage and better able to resist blight. Stands hot water better than the tall stem. Pkt., 10c.; 1; 0\%, 20c.: 0z..35c.; 1/ lb., $\$ 1.15: 1 b ., \$ 4.00$.

\section{Savoy Cabbages}

The Savoy or curly Cabbages are of exceutionally fine flavor and quality, and should be more generally cultivated. They are particularly adapted for private use. where quality rather than quantity is considered. Most delicious after frost.

Small Early Saroy-Best Early Dwarf Saroy: heads firm, solid and beautifully crimped finest uuality. Pkt., 10c.; $1 / 2$ oz., $25 \mathrm{c}$.; oz., $40 \mathrm{c}$; $1 / 4$ lb., $\$ 1.30 ; 1 \mathrm{~b}$., $\$ 1.50$.

Improved American Savoy-Superiur to the ordinary Drumhead Savoy offered under different names. Heads large and finely curled; short stalk: a compact grower; sure header; keeps well. Best for main crop. Pkt. yoc:

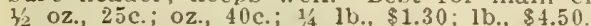

\section{NOTICE-All prices quoted in this catalogue are} subject to change without notice.

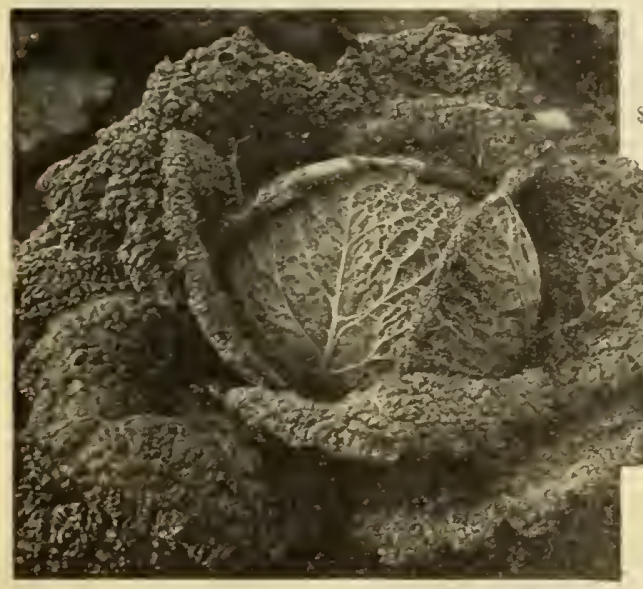

Improved American Savoy

\section{Livingston's Premium Flat Dutch}

Fuirs ago we set out to build up a strain of Large lat Flit Dutch Cabbage that would be better than any othe on the market, and now we have it in our livingston Premium Flat Dutch, Our purpose has been to weed out every objectionable point, and to fix firmly every good quality. It produces many tons to the acre, because of its: most large sorts, it is solid to the heart. Our stock seed is always grown from heads (not from stalks after the heads are taken off), fully developed and perfect in every respect This strain has no superior. The heads are large and very solid; open, white, are crisp and tender, and sure to head. Grown largely by marketmen on account of it: good shipping qualities. Plst.,10c.; 1/2 oz, 20c.; $0 z_{.}, 35 \mathrm{C}$ $25 \mathrm{c}$ : : oz.. 45c.: 1/4 lb., $\$ 1.40 ; 1 \mathrm{~b} ., \$ 5.0 \mathrm{f}$

\section{Livingston's Ideal Winter}

few days earlier than Livingston's Premium Flat Dutch, and one of the most magnificent strains of Late Flat Dutch known today. By persistent selection, year after year, it has been brought to a state of perfection rarely attained. The large, solid heads, the low, short stems. the absence of useless foliage, uniformity of siz and shape, reliability for heading, and long-continued seCabbage for profit. Pkt., 10c.; 1/2 0z., 20c.; oz., 35c.; 1/4 lb., $\$ 1.10$ : 1h., $\$ 3.75$

\section{Red Cabbages Danish Ironball (Red)}

As round as a ball and as hard as iron-these are the two leading characteristics of this elegant new solt. Heads grow to a large size, averaging 8 inches in diameter, of rich purplish color throughout. Pkt., 1Ac.; 1;: oz. 25 c.; oz., 45 c.; $1 / 4$ lb., $\$ 1.40 ; 1$ b., $\$ 5.00$.

\section{Extra-Early Blood Red Erfurt}

Earliest and reddest. Plit., 10c.; 1/2 oz.. 25c.; o\%, 40c.; 1/4 1h., \$1.30; 1h

\section{Mammoth Rock Red}

Heads as large as Large Late Flat Dutch; deep red to center. Highly recommended. Hard as a rock. Plit., 10c.: 1/z oz. 25c : Oz., 45c.: 1/, lb., \$1.40; 1b., \$5.00

C. M. Chapman, Benzee Co., Michigan, writes: "Your Danish Ball-Head Cabbage is the finest I ever ate ol" salw srown. Mlr. Frank Davis had the nicest garden of any one fol miles around and the vegetables were grown from your Tru* Blue Seed."

Stauton Iong, Jefferson County, Ohio, writes: "The Danish BallHead Cabbage seed which I purchased from you last Spring was cel-
tainly fine. I think every seed must have glown. The Flower seed was also fine.

I. B, Johnston, Green County, Pa., writes, Feb. 18, 1918: "I harl fine luck with youl" seeds last year. "I think almost every" seed grew". 'There never was any better seeds sent to a farmer than yours was last year. I assure you of my orier this spring if I get your hook." 


\section{Colifior Cauliflower slumentrohl}

Cauliflowers delight in a rich, moist soil, and in dry seasons should be abundantly watered, especially when heading. Sow the seed in the hotbed in January or February, and transplant the plants 2 or 3 inches apart in boxes or in another hotbed, until such time as they are safe to be planted in the open ground. Set the plants in the field 2 feet by 15 inches apart. If properly hardened off, they are seldom injured by being planted out too early. When heading, tie the outside leaves loosely over the head to protect it from the sun. One ounce produces from 1500 to 2000 plants.

\section{Dry-Weather}

(Also known as Danish Giant and Gilt-Fdge.) This is a fine, large, heavy variety that matures about week later than Livingston's Earliest. Cauliflower. It is especially adapted for growing in dry localities on account of its large leaves which furnish greater. protection to the heads. Pkt., $25 \mathrm{c}$.; $1 / 4 \mathrm{Oz}$., $85 \mathrm{c}$.

\section{Henderson's Early Snowball}

One of the best types of Cauliflower on the market. Its compact habit of growth renders it a very profitable variety to force under glass, and it does well for late planting, as well as for early crops. It is a sure header. Pkt., $25 \mathrm{c}$.; $1 / 4$ oz., $85 \mathrm{c}$

\section{Livingston's Green-House Forcer}

For a great many years we have realized that a variet of Cauliflower that would grow in a small space, and, at the same time, combine all the good qualities of our best sorts would be greatly appreciated by every one who forces this vegetable under glass. Livingston's Green-House Forcer is unexcelled for this purpose. Pkt, 25c.; 1/ oz., $\$ 1.10$.

\section{Extra Early Dwarf Erfurt}

Dwarf habit, compact growth; short outside leaves Can be planted 20 inches apart. Pkt., 25c.; 1/t oz., 85c.

\section{Large Late Algiers}

Popular with canners and market gardeners. Ample roliage protects the heads well, which remain a long time fit for use. Pkt., 10c.; 1/2 oz., 40c.; oz., 75c.

\section{Veitch's Autumn Giant}

Heads are beautifully white, large, compact. Pkt., 10c. $0 z, 35 c ; 0 z, 65 c$

\section{вerro Cress or Pepper-Grass rresse}

$A$ well-known pungent salad; can be used alone or with lettuce. Requires to be sown thickly (covering very lightly) at frequent intervals, to keep up a succession, as it soon runs to seed.

\section{Extra Curled}

Pepper Grass-MIay be cut two or three times Pkt., 5c.; oz., $15 \mathrm{c}$; $1 / 1 / \mathrm{lb}$ lb., $35 \mathrm{c}$; 1b., $\$ 1.25$.

\section{Water Cress}

Well-known hardy perennial aquatic plant. Is easily grown along margins of ponds and streams where it increases both by spreading of roots and seeding. Has a pleasant, pungent flavor. Growing Water Cress should prove a profitable enterprise where the condiitons are favorable. Pkt., 10c.; 1/2 oz., 30c.; oz., 50c.

\section{Upland Cress}

This is a hardy perennial; stays green nearly the whole year; ready for use in the Spring before any other salad. Eaten like Lettuce or boiled like Spinach. Sow in April in rows 1 foot apart. Plit., 5c.; oz., 20c.; 1/4 1b., 65c,

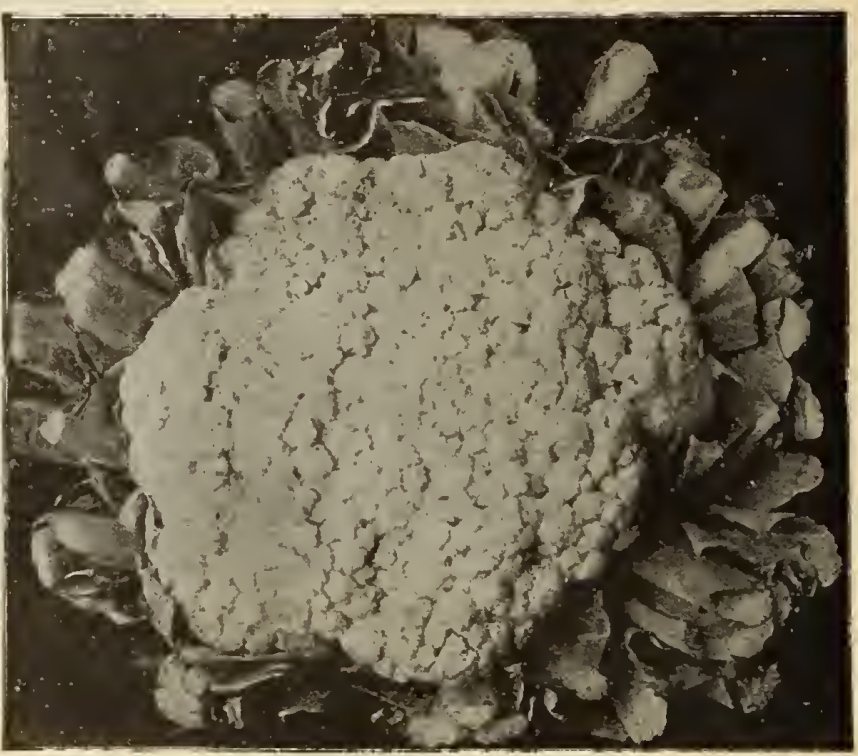

Iivingston's Earliest Cauliflower

\section{Livingston's Earliest}

Our grower in Denmark spares no pains or expense with this stock. For wintering in cold-frames it can not be excelled and it does equally well for a Fall crop if planted late and treated the same as late Cabbage. Livingston's Earliest Cauliflower should take the place of many of the late varieties on account of its fine texture, pure white heads, and large uniform size. A most compact grower and a sure header. Market gardeners throughout the country are perfectly satisfied with it.

Price (under our True Blue Seal), Pkt., 25c.; 1/4 0z., \$1.00.

\section{Collards}

A plant of the Cabbage family. It is well adapted to the South, enduring extreme heat; excellent for greens.

True Southern, or Georgia-Plit., 5c.; oz., 15c.; 1/4 1b., 40c.

\section{Witloof Chicory (French Endive)}

Sold by dealers in fancy fruits, during the winter and usually brings high prices. Imported in large quantities from Europe but equally as good can be grown here. Sow the seed in June in open ground in rows 12 to 14 inches apart, keeping free from weeds and watering if necessary. Take up the roots in November and cut off top to about $21 / 4$ inches from the neck and shorten lower end to a uniform length of 8 or 10 inches. Prepare a trench 16 to 18 form length of 8 . or 10 inches. Prepare a trench 16 to 18 inches deep and place roots upright $1 \frac{1}{2}$ inches apart. Fill in level with good, light soil and any portion may be weeks the heads will be ready for use. The blanched head. is the edible portion and is generally eaten raw as a salad.

IVitloof may be grown indoors during the winter, furnishing a delightful salad when other fresh vegetables cannot be had. The ideal place is in the celler, where a temperature of near 60 degrees can be maintained and temperature of near 60 degrees can be maintained and where absolute darkness can be had. Provide a bed or tox, as space permits, at least 18 inches deep and put in each way, piercing the soil about 3 inches. Fill in between the roots until crown is just covered, packing the soil lightly. This now leaves about 8 inches which ean be filled in with more light soil, or better, clean, sharp sand. Keep the bed absolutely dark by covering with an old carpet or boards, and water as necessary, but do not keej soget Heads are ready for use as soon as they show above the sand which should be from two to three weeks. For indoor culture, the roots should be stored in a cool, For indoor culture, the roots should be stored in a cool, $30 \mathrm{c}$; $1 / \mathrm{t}$ lb., $85 \mathrm{c}$; $1 \mathrm{~b} ., \$ 3.00$.

\section{Corn Salad or Fetticus}

A vegetable used as a salad. Sow the first opening of spring for Summer use in rows 1 foot apart, and it is fit for use in six or eight weeks.

Iarge I eaved-Pkt., 5c.; oz., 15c.; 1/ 1b., 50c.; lb., $\$ 1.75$, 


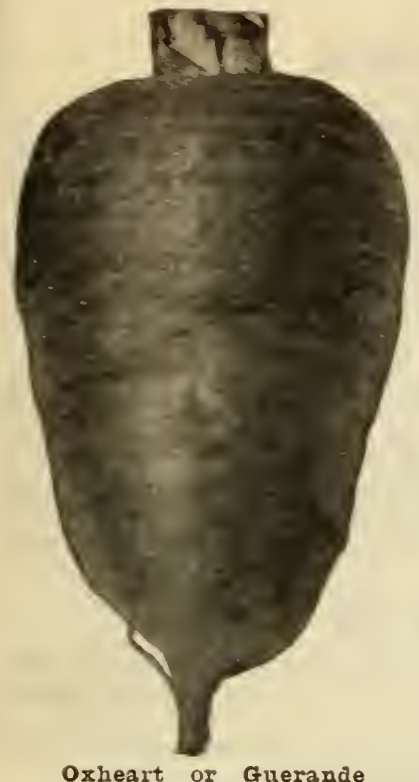

Oxheart, or Guerande

Intermediate length; is fully 3 to 5 inches in diameter; quality extra good. Some sorts require digging, but the Oxheart can be easily pulled. It is especially adapted to shallow soils, where the longer sorts would not
thrive as well. Pkt., 5c.; oz., 10c.; 1/4 lb., thrive as we 1 w. $90 \mathrm{c}$

\section{Early French Forcing}

The earliest small round variety, much used for first early forcing in hot beds. Color reddish orange, and bunches rery nicely; used largely for market, as well as kitchen garden. Quality the best. Pkt., 5c.; oz., $15 \mathrm{c}$, , $1 / \mathrm{z}$ lb., $45 \mathrm{c}$.; 1b., \$1.50.

Sow in early Spring in drills 15 to 18 inches apart, finally thinning the plant to 3 or sown early on a moist soil a half-inch is deep enough is slow to germinate, Keep clean by frequent hoeing neglected, the young plants are easily smothered, and the crop is lost. One ounce sows

Carrots for Table Use

\section{Livingston's Early Market}

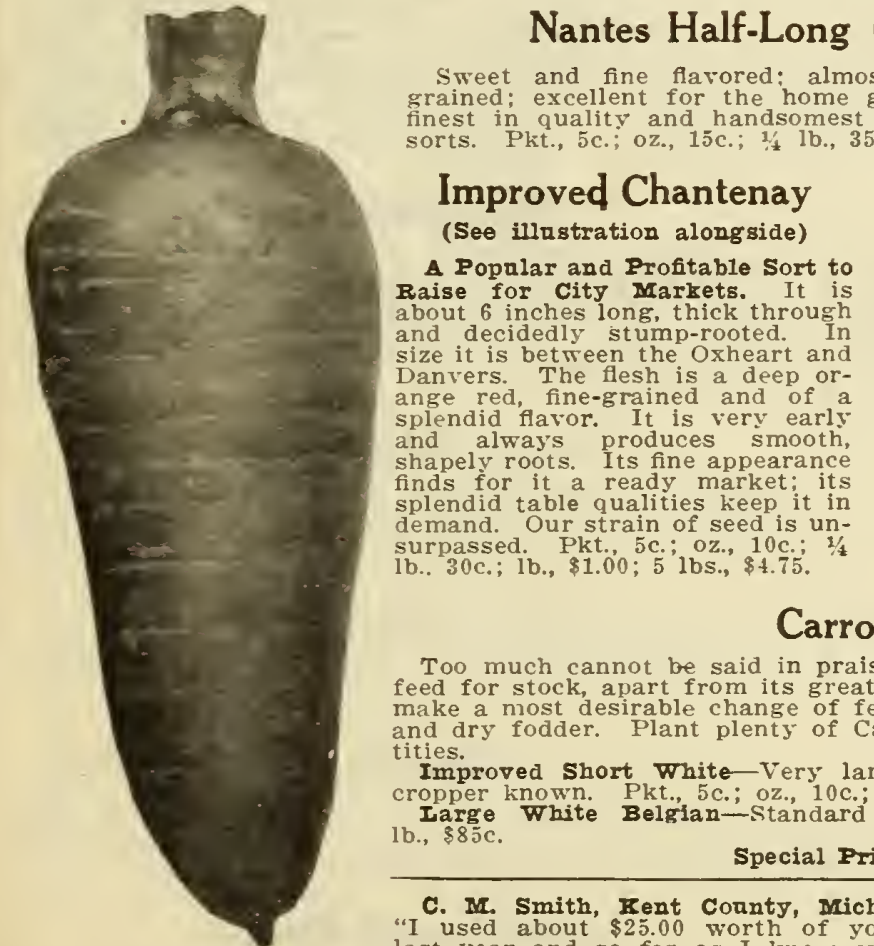

\section{Improved Long Orange}

The standard late variety, very handsome and uniform in shape; roots are of deep orange color, good flavor; yields very heavily. Requires a deep soil. Plants should stand 6 inches apart in 18-inch drills for roots to attain their full size. The roots are smooth, fine-grained and very large, growing to 12 inches in length and 3 inches in diameter. For feeding milch cows is is and imparts to the butter a rich golden hue Pkt., 5c. oz., 10c.; $3 / 4$ lb., 30c.; 1b., $\$ 1.00 ; 51 \mathrm{bs}$., $\$ 4.75$.

\section{Early Scarlet Horn}

For forcing and early garden use; flesh deep orange, fine grained; agreeable flavor; small top stump rooted. Pkt., 5c.; oz., 15c.; $1 / 4$ 1b., 35c.; 1b., $\$ 1.25$.

\section{Carrots for Stock Feeding}

Too much cannot be said in praise of the Carrot as a wholesome addition to the Winter feed for stock, apart from its great value as a vegetable for table use. The splendid rnots make a most desirable change of feed for your cattle when given in connection with grain and dry fodder. Plant plenty of Carrots for all purposes. Ask for prices in larger quantities.

Improved short white-Very large, half-long roots; nearly white. It is the heaviest cropper known. Pkt., 5c.; oz., 10c.; 1/4 lb., 30c.; lb., $\$ 1.00$

Iarge White Belgian-standard for field culture. Pkt., lb., \$85c.

Special Prices on Carrot Seed in Quantity

C. M. Smith, Kent Connty, Mich., writes "I used about $\$ 25.00$ worth of your seeds last year and so far as I know every seed grew and was true to variety and produced
Mr. Edward G. French, Caledonia Co, Vt. writes as follows: "MI order of Seeds came yesterday. They seem to be all right, and I thank you for your proinptness. This is the fifth order I have bought of you. 


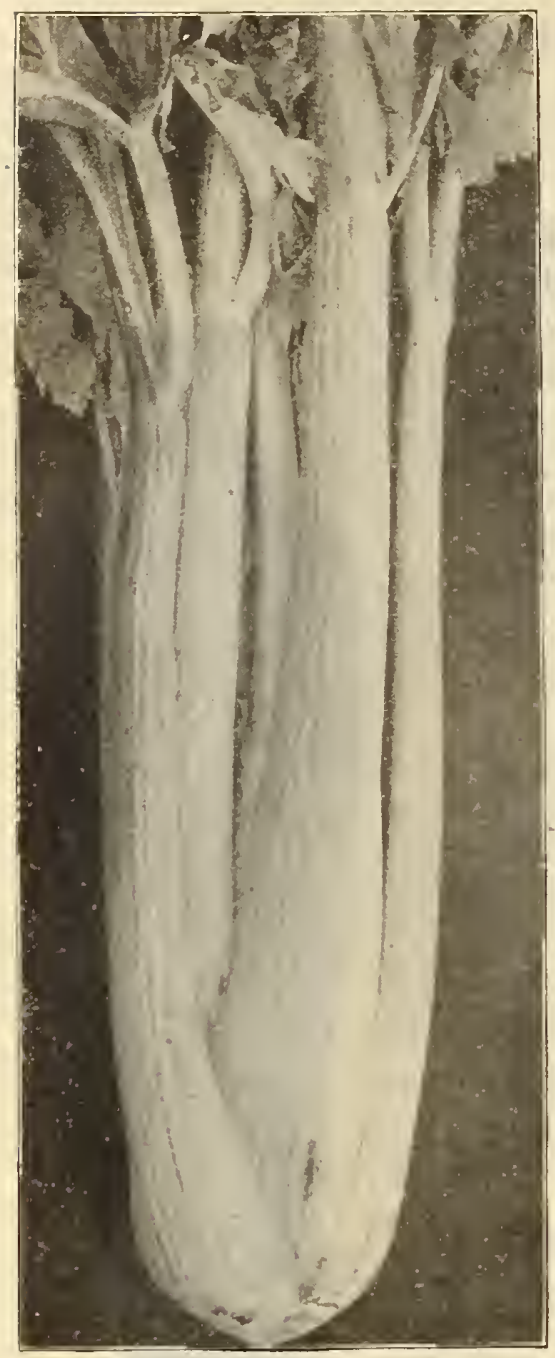

Collirilia

\section{Giant Pascal}

Forms solid, crisp stalks of incomparable flavor. Of strong growth, producing perfectly blanched stalks when hilled up properly. Of rich, nutty flavor. Blanches very easily and is very brittle. A fine leeper, an excellent shipper, retaining color and fresh appearance a long time. A favorite with Southern growers. For mid-Tinter use it is excellent. Plit., 5c.; 1\% Oz., 10c.; Oz., 15c.; 1/ 1b., 50c.; $1 \mathrm{~b} ., \$ 1.75$.

\section{Livingston's Snowhite}

For full description sec specialty pages. Plit., 10c.; $1 / 2$ oz., 25c.; oz., 45c.; 1/4 1b., $\$ 1.50$.

\section{WINTER QUEEN}

Of short, stocky growth, with broad, heavy stalks. An excellent variety for Winter use. When blanched, the stalks are of a creamy-white color and very attractive. Its flavor, crispness and long-keeping qualities combine to make this sort one of the best Tinter varieties. Pkt., 5c.; $1 / 2$ oz., 10c.; oz., 15c.; $1 / 4$ 1b., 45 c.; 1b., $\$ 1.50$.

Joe Bruttaniti, Kanawha Co., W. Va., writes: "The Celery Seed bought from you last year made me one of your customers and I will have no other seeds planted in my garden this yeal b'it Livingston's Seeds."

Mrs. Roy Beery, Hocking" Co., writes as follows: "I want to say a word for the Many Fold Tomato and Snow White Celery, both proved to be the best 1 ever raised, and am ordering more with this order.'

\section{Apio Celery sellerie}

Celery can be successfully grown with but little labor, in any good garden soil, by using plenty of well-rotted eral sprinkling of coarse salt worked into it, and this mixture should be put in the trenches, working it well into the soil, at least wer plants are transplated into them. It delights, howas soon as fit to work in the Spring. Prepare the soil well before four feet apart where soil is used. One ounce of seed produces about 2000 plants. Plenty of seed should be used so that the best plants may be selected

\section{Golden Self-Blanching}

grand Celery is of French origin. It has the demand above all other White plume, but is much heavier and more compact, though not solid, crisp, brittle, of excellent quality and very beautiful.

Stalks and portions of the inner leaves and heart are so nearly white naturthe that tying or simply drawing the soil up against the plants will complete texture; adapted to Fall and early Winter use; a good keeper up to the holiday

An early maturing sort, unsurpassed in shape and quality. The plant is of

\section{Columbia}

medium height, but very stocky and heavy. The stalks are thick, almost the rich yellowg in shape those of Giant Pascal; the color has in it more of f a distinctly light shade of green with a tillge of yellow. In season it follows fine, some considering it equal or even superior to either Golden Self-Blanching ol Giant Pascal. Plit., $10 \mathrm{c}$; ; $1 / 2$ oz., $15 \mathrm{c}$.; 0z., $25 \mathrm{c}$.; 1/1 1b., 75c.; $1 \mathrm{~b} ., \$ 2.50$.

\section{- Easy Blanching}

A new variety remarkably easy to blanch, which together with its being adapted to early use as well as storing for winter make it especially suitable for the home garden. Stalks thick, brittle and excellent flavor; plant strong. healthy grower. Recommended especially to those who have not been successful with other sorts. Plit., 10c.; $.1 / 2$ oz., 20c.; oz., 30c.; 1/1 lb., 85c.; lb., \$3.00.

\section{Dwarf Golden Heart}

Solid; an excellent keeper and of fine, nutty flavor. Heart, which is large and full, is a light yellow. $\Lambda$ showy and desirable variety for marliet. Plit., $5 \mathrm{c}$; $1 / 2$ oz., 10c.; 0\%, $15 \mathrm{c}$; $1 / 4$ lb., $50 \mathrm{c}$.; 1b., $\$ 1.75$.

\section{Giant Golden Heart}

In quality, appearance and large size, it is one of the best varieties for market gardners. Pkt., $5 \mathrm{c}$.; $1 / 2$ oz., $10 \mathrm{c}$.; oz., 15c.; 1/4 1b., 50c.; 1b., \$1.75.

\section{Celeriac Turnip-Bootea celery}

Sow sefed the same as for Celery. Transplant into rows 2 feet apart and 9 inches in the low. Thorough cultivation is necessary to secure good roots. Earthing up is not necessary. The roots may be cooked or used as salad.

\section{Giant Smooth Prague}

A large and smooth variety. Desirable for market; an excellent keeper; select stock. Pkt., 10c; oz., 15c.; 1/4 1b., 


\section{Maiz dalce Corn, Sweet or Sugar speise «ais}

The Sweet or Sugar Corn Tarieties, being liable to rot in cold or wet ground. should not be planted until Mras when the soil has become warm and dry. For a full supply for the table during the entire lays or two Weeks until the last week in July, in hills $2 \times 3$ feet apart for the early kinds, and $3 \times 3$ feet for the large 15 to 16 ponnds will sow an acre.

SWEET CORN PRICES in quantities up to and including 2 pounds include prepayment of postage. yuantities are wanted sent by mail, it will be necessary to remit additional amount at the Parcel post rates. page 3 for rates.

\section{Livingston's Earliest on Earth}

The earliest of the golden or yellow sorts. For full description see Specialty Pages. Plit., 10c.: $1 / 2$ lb., $20 \mathrm{c.}: 1$ 12 lbs., $\$ 2.00$; 48 lbs., \$7.50.

\section{Golden Bantam}

One of the finest. Ears are about 6 inches long, eiglit rowed, filled with broad, sweet, golden vellow kernels of a delightful flavor. It is as early as the Cory and of much better flavor. It is always good, whether planted in the spring or during the summer. We confidently advise al lovers of a real good find out how good it is is to try plant enough, or you'll be sorry when you begin to eat it. Hit. 10c: 1 , 1b. 20c: 1b. $30 \mathrm{c}: 2$ lbs. $55 \mathrm{c}$. By express, not paid: 6 lbs., $1.25 ; 12$ lbs., $\$ 2.15 ; 48$ lbs., $\$ 8.00$.

\section{Golden Cream}

\section{A Golden Country Gentleman}

The good old Country Gentleman Sireet Corn has always been recognized as the sweetest of all the late varieties. since the introduction of the Golden Bantam it has easily taken the lead as the sweetest of the Extra Early sorts. Now in this New Golden Cream we have the two united, retaining all the streetness and fine flavor of both, also the color of Golden Bantam, but lighter ellor, and the iuregular rows of Country Gentleman. The Golden Cream matures later than Golden Bantam. Quality very fine - street and tender. Pkt.

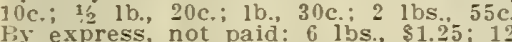
liss., $\$ 2.15$.

\section{Bantam Evergreen}

\section{Golden Bantam Crossed with Stowell's} Evergreen

In crossing these two excellent vaieties none of the good qualities of either has been lost: rather it surpasses them in sweetness and tenderness. While not an extra early sort, it comes in just right in season to follow the first early sorts. We predict this corn to become one of the leading sorts once its good qualities are gensorts once its good qualities are gensiseet Corn to at least give Bantam Evergreen a trial. Plit., 10c.; $1 / 6 \mathrm{~b}$, press, not paid: 6 lbs $\$ 1.30$; 12 lbs., $\$ 2.25$

\section{Peep-O-Day}

The stalks of Peep-O'-Day Corn grow from $3 \frac{1 / 2}{6}$ to 41, feet high and bear from 2 to 3 ears each. The foliage is light green and being small, stalks will stand very close planting. Have the row's just far enough apart to adinit of thorough cultivation, Pkt., $10 \mathrm{c}$. 1. 1 lb., 20c.; 1b., 30c.; 2 lbs., 55 c. By express, not paid: 6 ibs., $\$ 1.30 ; 12$ lbs., expre

\section{Extra-Early Premo}

A "sixty-day" Sweet Corn that comLines all the merits of the leading varieties, and is superior to many of them in size, quality and yield. Premo can be planted fully as early as the Adams, for the young plants withstand clight frosts, While the other varieties 5 feet high, and are very vigorous, generally bearing tro well-developed ears to the stalk. Pkt., 10c.; 1/2 1b., 20c.: paid: 6 ibs., $\$ 1.25$ : 12 lbs., $\$ .15$.

\section{Extra-Early Adams}

Same size, type and style as Early - dams. Hardiest and earliest Corn. It is not a Sugar Corn, but is grown for early use. Ears short; kernels 25c.; 2 lbs., 45 c. Ey express, not paid: 6 lbs., $\$ 1.00 ; 12$ lbs., \$1.70; $4 \$$ lbs., $\$ 6.25$.

\section{Early Adams}

Similar to Extra-Early Adams; ear somewhat larser, but not quite so the above, is hardy, and can be planted early. Plit., 10c.; 1, 1b., 15c.; 1b., 25c.; lbs., \$1.00; 12 lbs., \$1.65; 48 lbs., $\$ 6.00$.

\section{Kendel's Early Giant}

The ears are large, measuring 8 to 9 more long, thick through, with ten or kernels, that are of most deliciously sweet flavor. It is several days earlier than Shaker's Tarly, which gives it the distinction of being an early and at the same time a large-eared variety. deners report this Sweet Corn ready to use in sixty days when grown on ground. Owing to our shillful selection year after year, Kendel's Early Giant has become a much more valuable sort than when first introduced. $55 \mathrm{c}$. By express, not paid: 6 lbs., $\$ 1.20$. 12 lbs., $\$ 2.00 ; 48$ lbs., \$7.50.

Extra-Early Cory-White Cob-This variety" succeeds well where the Summer is short, cool and moist. Ears six inches in length with eight rows of quite broad grains. Pkt., $10 \mathrm{c}$; $1 / 21 \mathrm{~b}$., not paid: 6 ibs., $\$ 1.20 ; 12$ lbs., $\$ 2.00$; 48 lbs., $\$ 7.50$

Early Minnesota- White

kernels. Pkt., 10c.; 1.2 lb, $20 \mathrm{c}$ and 6 lbs los, 5jc. By express, not paid

Mammoth White Cory-This new strain is as early as the original Exsize, and kernels more compact. and kernel are pure white. Pkt., 10c. $1 / 2$ lb., 20c.; 1b., 30c.; 2 lbs.. $5 \overline{5}$. B $\$ 2.150^{\circ}$ is Ibs. \$s:00.

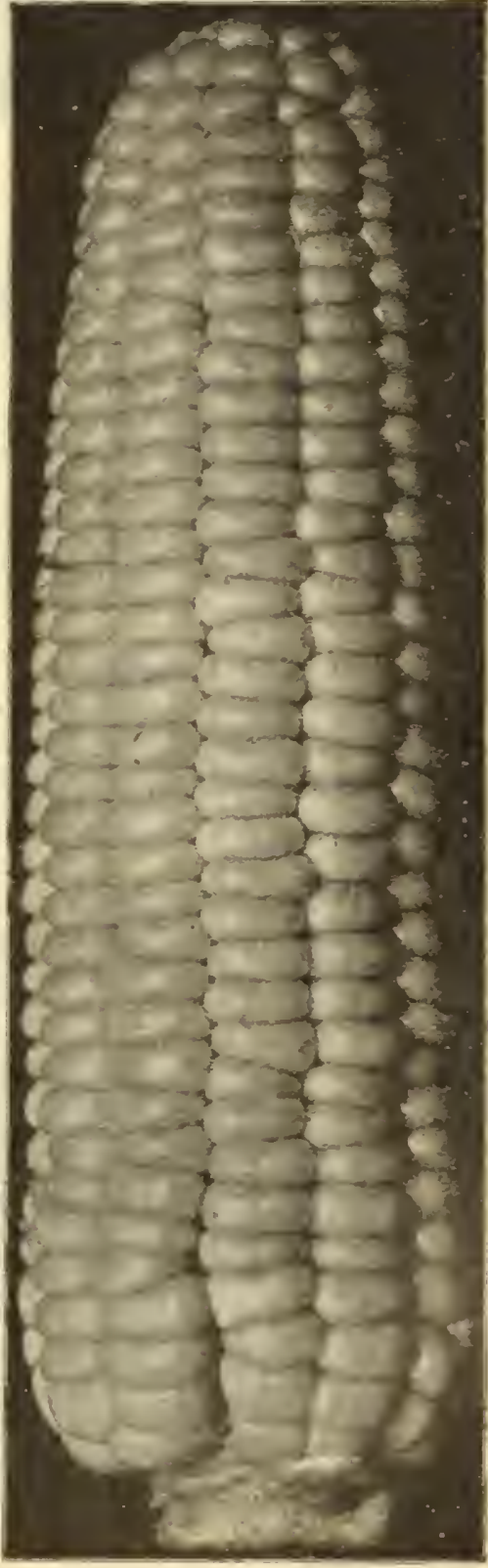

Livingston's Early Stigax 


\section{Sweet Corn (Continued)}

\section{Livingston's Broad-Grained} very Broad and Sweet

For a number of years this variety has been closely selected to produce the broadest possible grains, and at the same time to retain its depth of grain and splendid quality. The grains are simply enormous when who enjoy running a knife blade down through the rows of arains before eating, Livingston's BroadGrained Sweet Corn is unexcelled; there is no dodging of the knife about these is no dodging of the knife about these type and 7 or 8 inches long. It matures very soon after the Extra-Early varieties. Pkt., 10c.; $1 / 2$ lb., 20c.; lb., 30c. $\$ 1.20 ; 12$ ibs., $\$ 2.00$.

\section{Livingston's Evergreen (Red Cob)}

Our old original variety, introduced by us in 1860 , and now a general favorite for family use, as well as market purposes. It is a first-class second-early sort. Productive, large, well-filled ears, with broad kernels and small cob, filled well over tip. Pkt., 10c.; 1/2 lb., 20c. lb $30 \mathrm{c}, 2$ lbs $55 \mathrm{c}$. By express, not paid: 6 ibs., $\$ 1.10 ; 12$ Ibs., $\$ 1.90$

\section{Livingston's Evergreen (white Cob)}

This is our old Livingston's Evergreen (described above), with a white cob. Pkt., 10c.; 1/2 1b., 20c.; 1b., 30c. 2 lbs., 55c. By express, not paid: 6 lbs. $1.10 ; 12$ lbs., $\$ 1.90$

\section{Early Evergreen}

An early strain of Evergreen Sweet Corn must be of great value. This varlety resembles the Stowell's Evergreen but is ready for use much earlier and remains in good condition equally as long The ears grow to a good size usually about 7 inches long, and contain from 16 to 18 rows of deep, sweet grains. Pkt., 10c.; 1/2 lb., 20c.; 1b., 30c.; 2 lbs $55 \mathrm{c}$. By express, not paid: 6 lbs., $\$ 1.10$; 12 ibs, $\$ 1.90 ; 48$ lbs., $\$ 7.00$.

\section{Stowell's Evergreen}

A favorite with canners and market car favorite with canners and the kitchen garden. Ears large, kernels very deep, tender and of most delicious sweetness; very productive. Pkt., 10c.; $1 / 2$ lb., 20c.; lb., 30c.; 2 lbs., 55c. By $\$ 2.00 ; 48$ lbs., $\$ 7.50$.

\section{White Evergreen}

This is a high-bred, pure-white type of the ever-popular Stowell's Evergreen. From one pure white-grained ear, accidentally descovered some years ago, it has developed by careful selection. Stalks very vigorous, 6 to 7 feet high. The ears are uniformly very large and well-filled. When in the green state weth cob and kernel are white as snow. Pkt.; 10c.; 1/2 lb., 20c.; 1b., 30c.; 2 lbs. $55 \mathrm{c}$. By express, not paid: 6 lbs., $\$ 1.10$ 12 ibs., $\$ 1.90 ; 48$ lbs., $\$ 7.00$.

\section{Narrow-Grained Evergreen}

A selection of Stowell's Evergreen, retaining its large size and productiveness and adding the delicious sweetness of Country Gentleman. There will be less trouble for the Canners to get the farmer to grow Narrow Grained Evergreen on account of increased yield. The market gardener should find ready sale for this large, medium late sol't. We believe our stock of it will be found superior to much that is offered. Get started raising some of this variety this season. You will be pleased. Pkt., 10c. $1 / 2$ lb., 20c.; 1b., 30c.; 2 lbs., 55c. By express, not paid: 6 .

\section{Columbus Market \\ (See illustration below)}

Ready for table with the second earlies, such as Crosby's Early, Shaker's Early, etc., but is fully twice as large as any of them. The ears carry an average of 16 rows of fine large, deep, white and very sweet grains, which are second to none in tenderness and flavor. The stalk is very strong, sturdy and of only medium height; the leaves broad and dark green in color, a habit of rowth which gives it great endurance during a dry time Especially adaptec for early trucking: also very desirable for the home garden. Pkt., 10c.; 1/2 1b., 15c.; lb., 25c.; 2 lbs., 45c. By express, not paid: 6 lbs., $\$ 1.00 ; 12$ ibs.

\section{Metropolitan}

The plant is distinct, being very strong of stalk, growing about 5 to 6 feet in
height. The ears are from 8 to 9 inches and are set low on the stalle. wars are well filled with large, white deep grains which are equal in flavor to $20 \mathrm{c}$; 1 b. 30c.; 2 lbs., 55c., $10 \mathrm{c}$; ${ }^{1 / 2} \mathrm{lb}$. not paid: 6 lbs., $\$ 1.30 ; 12$ lbs., $\$ 2.25$.

\section{Aristocrat}

Follows Mammoth Thite Cory in season. A very desirable variety early, dwarf sort, ears 8 inches long, with very broad grains; very productive. Pkt., 10c.; $1 / 2$ lb., 20c. lb., 30c. ${ }^{2}$ lbs., $55 c$ By express, not $p$

\section{Country Gentleman}

One of the Richest Flavored of all the late varieties. As a unrivaled, and without doubt is the most luscious of all varieties of Sweet Corn. The plump. pearly-white kernels are of great depth, and most delicious, and the flavor will delight an eplcure. We have selected this pecially proud of our strain. It comes as true to type as any we have ever seen. Ears average 9 inches long by 2 inches in diameter and are typical 10c.; 1/2 1b., 20c.; 1b., 30c.; 2 lbs., $55 \mathrm{c}$. By express, not paid: $6 \mathrm{lbs}$., $\$ 1.25 ; 12$ lbs., $\$ 2.15 ; 48$ lbs., $\$ 8.00$.

\section{Black Mexican}

One of the sweetest varieties, color when in roasting ear, purple and white; also a fine late sort. Pkt., 10c.; $1 / 2$ lb., 20c.; 1b., 30c.; 2 lbs., 55c. By express, not paid:

\section{Mammoth Late Sugar}

Produces larger ears than any other Sugar Corn and of good quality; a rich, and very sweet late variety. Pkt., 10c.; $1 / 2$ lb.,

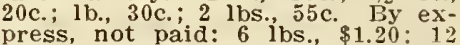
lbs., $\$ 2.00 ; 48$ lbs., $\$ 7.50$

\section{"4 Best" Sweet Corns for Home Gardens}

This collection will supply the table continuously throughout the entire seasor. Mammoth White Cory (extra early) Columbus Market (early); Country Gentleman (main crop), New White Evergreen (late). One large plit. each of above, $30 \mathrm{c}$; ; $1 / 2$ lb., $70 \mathrm{c}$; $1 \mathrm{~b}$. of each, $\$ 1.00$ postpaid.

\section{Sweet Corn for Fodder}

Sow thickly in drills or broadcast at the rate of from 100 to 150 lbs per acre. Express, not paid: 12 lbs., $\$ 1.10 ; 48$ l lbs., $\$ 4.00$.

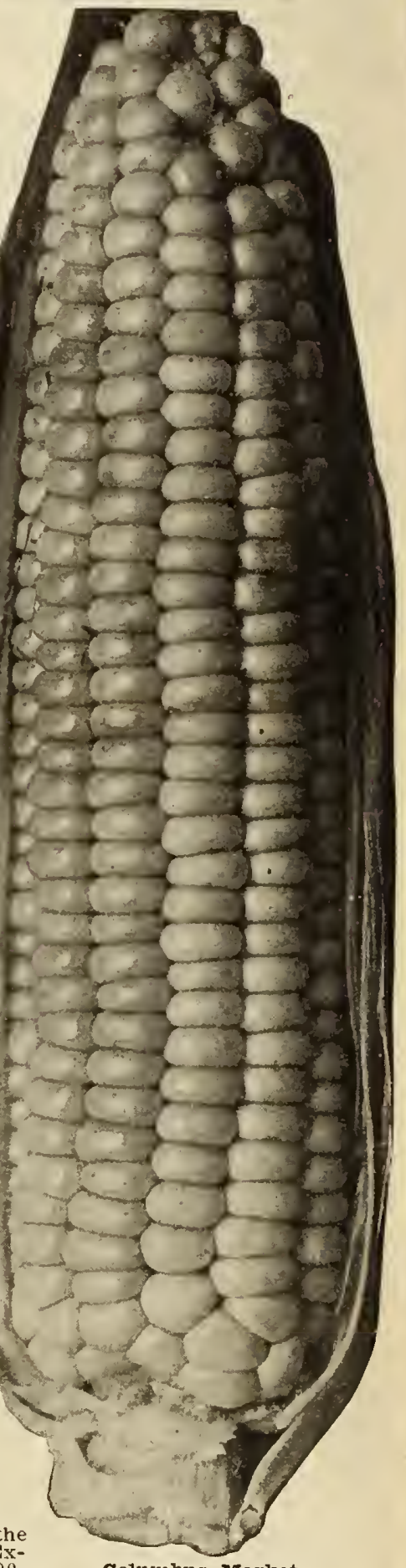

Columbus Market 


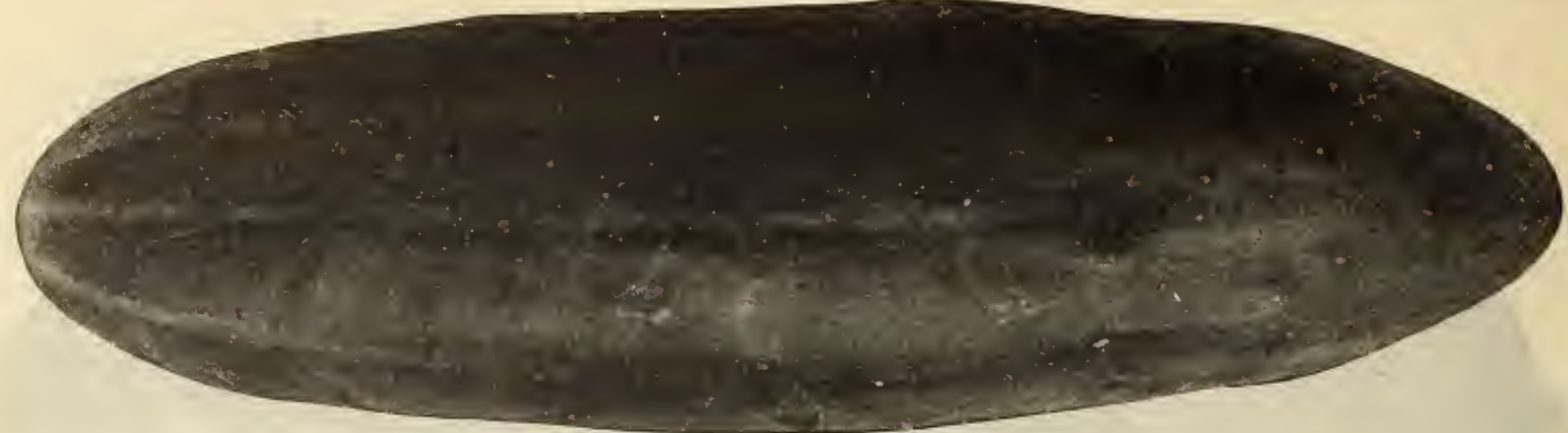

Iivingston's Davis Perfect Cucumber

\section{Davis Perfect}

By using this variety gardeners can produce out-of door Cucumber's that will sell in the market for hothouse forcing varieties. The shape is ideal. It is almost seedless one-third of its length from the stem, and the few seeds that are contained in its blossom end when in cating condition are so small and tender that they are hardly noticeable. Most imnortant of all, it does not lose its dark, rich color when grown out-doors. Pkt., 5c.; 0\%, 15c.; $1 / 4$ 1b., 35c.; lb., \$1.25.

\section{Improved Long Green}

(See illustration below.) The vines are very strong growing and productive. The fruits are quite long, averaging 10 to 12 inches in length. This sort is very popular both as a slicer and for nickles. One of the best general purnose Cucumbers. Pkt., $5 \mathrm{c}$.; 0\%, 15c. 1/ 1b., $35 \mathrm{c}$. : 1b., $\$ 1.25$.

Westerfield Chicago Pickling-Popular with Chicago gardeners. Medium length, slightly pointed at ends; very large; prominent spines; deep green. Pkt., 5c.; oz., 10c.; $1 / 1$ lb, $30 \mathrm{c}$; $1 \mathrm{~b}, \$ 1.00$.

Jersey Pickling - Intermediate between Long and Short Green. Long, slender, cylindrical; crisp and tender. Plit., $5 \mathrm{c} . ; 0 z ., 15 \mathrm{c}$; ; $1 / 4$ 1b., $35 \mathrm{c}$.; lb., $\$ 1.10$.

Extra-Farly Russian-Small, extra-early; hardy; productive, good for small pickles. Pkt., 5c.; oz., 10c.; '1/4 lb., $30 \mathrm{c}$; 1b., $\$ 1.00$

\section{Curious Cucumbers}

Serpent or Snake Cucumber-A great curiosity. Intersting for children or for exhibition. The cucumbers grow curled un like a snake, with head protruding; someiimes several feet in length. Pkt., 10c.

Gherkins (True West India)-Used only for pickles. Pkt.. 5c.; oz., 20c.; $1 / 4$ lb., 65 c.; lb., $\$ 2.00$.

"Iemon" Cucumber-A desirable variety, having a strong resemblance to a lemon in its size, shape and color Pick just as it turns yellow. Pkt., 5c.; $1 / 2$ oz., $15 \mathrm{c}$; $0 \mathrm{z} ., 25 \mathrm{c}$.

Japanese Climbing-Vines extra strong; being a climbing sort, can be grown on trellises or other supports; valuable in small gardens. The cucumbers are long and of fine flavor. Plit., 5c.: $1 / 2$ oz., $10 \mathrm{c}$.: $0 \%, 15 \mathrm{c} .: 1 / 4 \mathrm{~b} ., 40 \mathrm{c}$ : ilo., $\$ 1.25$.

\section{Livingston's Emerald}

(Introduced by us in 1897)-We were eight years in perfecting this variety, which represents a dark green cucumber that will hold its color. It is strictly an evergreen, retaining its color until quite ripe, making it very attrac-
tive. The vigorous vines abound in long. straight, handsome fruits of the most desirable qualities. As a slicer the flesh is perfectly crisp and tender and the flavor most pleasing. The young fruit is dark green, straight, slender and almost spineless: makes an excellent pickle, and when ripe none excel it for making sweet pickles. It is not excelled for beauty in color and form. Excellent shipping variety. Crop very short. Plit., 5c.; oz., $15 \mathrm{c}$.

Early Frame, or Short Green-A popular early variety of medium size and good shape; good for small pickles. Pkt., 5c.; 0z., 10c.; 1/4 1b., 30c.; 1b., $\$ 1.00$.

Nicliol's Medium Green-Introduced by us in 1883 . Color dark green: flesh crisp and tender: medium size; straight and smooth; a real handsome and prolific variety. Pkt. 5 c.; Oz., 10c.; $1 / 4$ lb., 30c.; lb., $\$ 1.00$.

Early Green Cluster-Short and prickly; bearing in clusters; prolific; fine for bottling. Pkt., 5c.; oz., 10c.; $1 / 4 \mathrm{ll}$., $30 \mathrm{c}$; 1b., $\$ 1.00$

Cool and Crisp-The beautiful green color is all that cal be desired. Excellent for nickling or slicing. Pkt., 5c., oz., 10c.; $1 / 4$ lb., 30c.; 1b., $\$ 1.00$.

Rawson's Hothouse-A very fine strain of Cucumbers for forcing in greenhouses. Fruit is about two inches onger and darker green in color than White spine, Plkt. $10 \mathrm{c}$; $1 / 2$ oz., $35 \mathrm{c}$.; Oz., $65 \mathrm{c}$.; $1 / 4$ lb., $\$ 2.25 ; 1 \mathrm{~b}$., $\$ 8.00$.

The "Vickery" Forcing-Rich, dark green in color, immense cropper. A choice variety for hothouse growers: also hard to excel for out-door cultivation. Pkt., 10c. 1/ oz., 35c.; oz. 60c.: 1/4 lb., $\$ 2.00 ; 1$ lb., $\$ 7.00$.

Rollison's Telegraph-Grows about 18 inches long; bright rreen, and is almost seedless. For greenhouse growing. Pkt. of 15 seeds, $25 \mathrm{c}$.

\section{Dandelion}

Sow in May or June, in warm, rich, soil, in drills half an inch deep and 18 inches apart. Some of the plants will be ready for use in september, balance the following Spring. Make delicious greens. One ounce will sow 150 feet of drill.

Iarge-Ieaved-Leaves fully double the size of the common Dandelion. Years of the most careful cultivation har? developed a very fine strain of seed. Pkt., 10c.

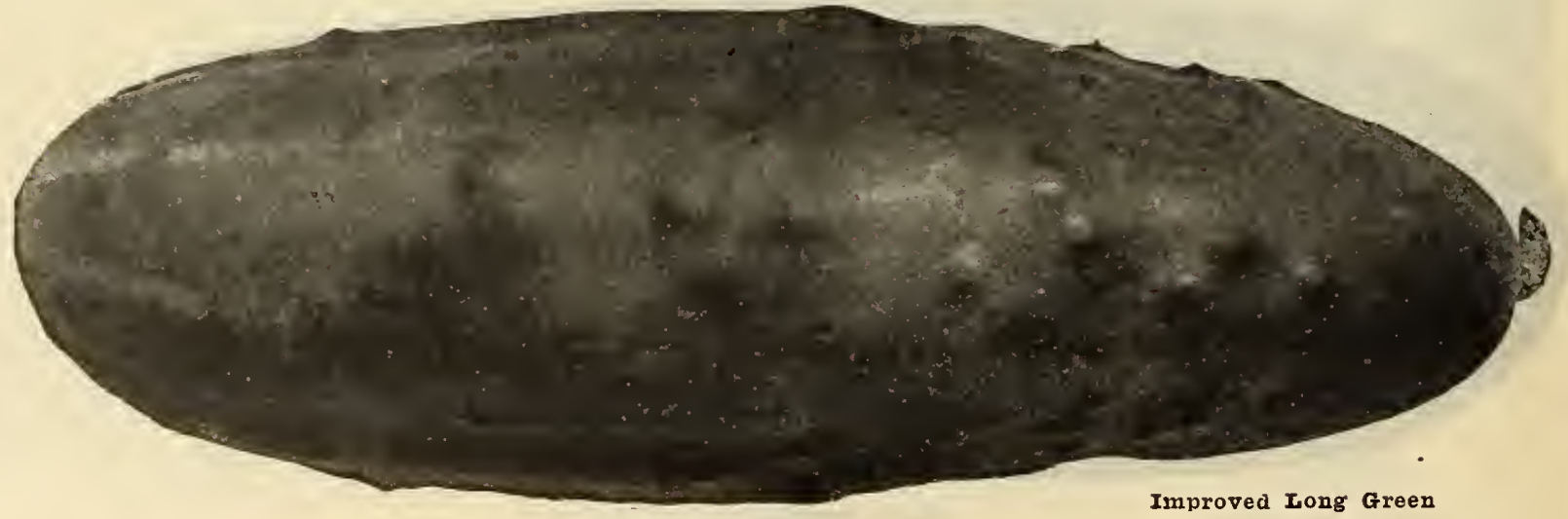




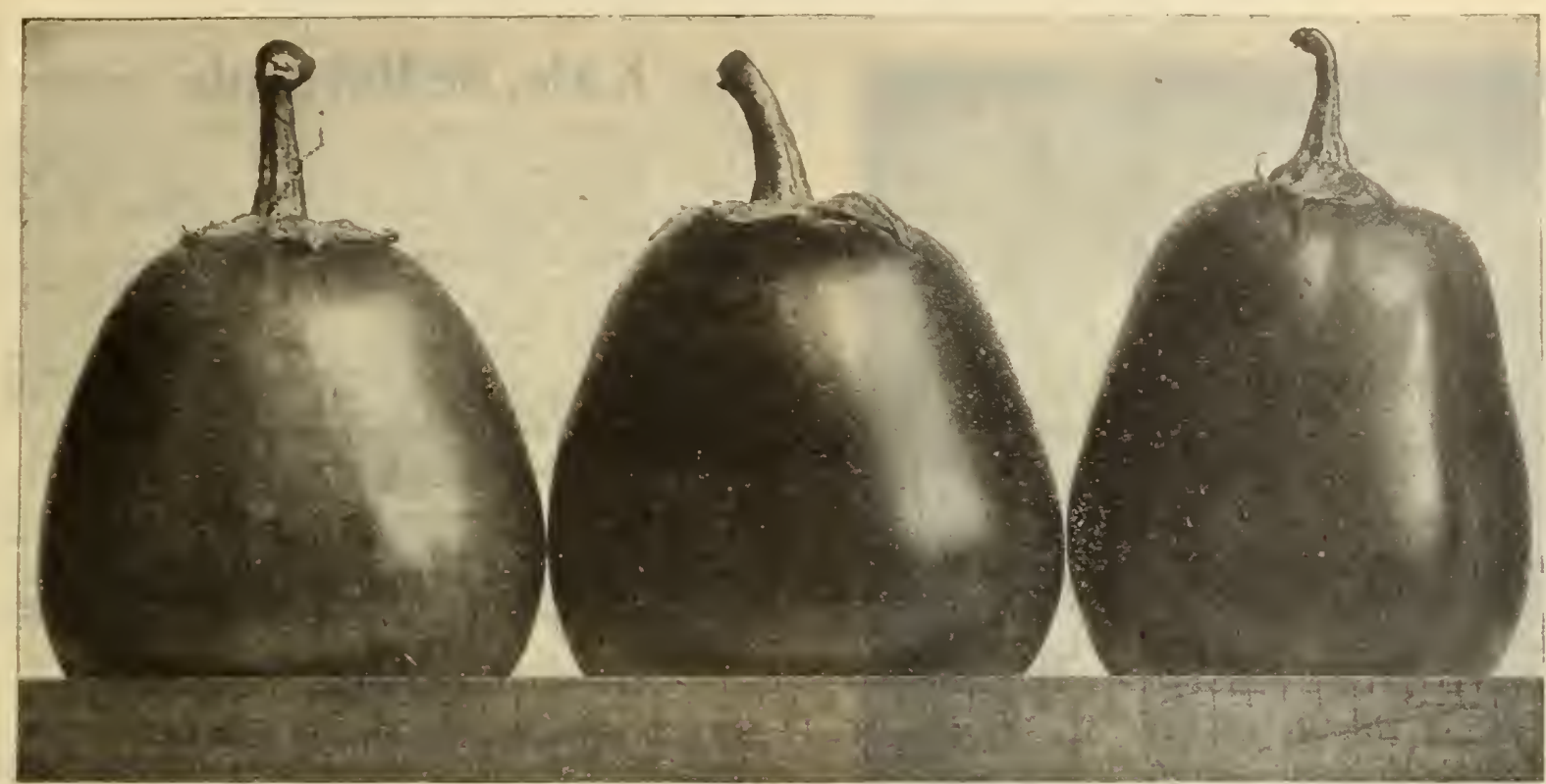

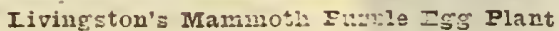

\section{Berenjena Egg-Plant Eierpianze}

Sow seeds in hotbed or warm rreenhouse in March or early in April; if no hotbed is at hand, they may be grown in any light room where tle temperature will average 75 degrees. Then plants are two inches high, or have formed two rough leaves, transplant them into beds and set 3 to 4 inches apart. Ireep beds closed and very warm, shading from direct rays of the sun and giving an abundance of water until the ground is warm and all danger from frost and cold night is past; then harden the plants by gradual exposure to the sun and air, and increase the supply of water: transplant to the open ground late in Nay or June, into warm rich soil, 2 to 3 feet apart each way, according into warm, rich soll, 2 to 3 feet apart each way, according to the richness of the ground. When about a foot high, cuting the fruit so as not to disturb the roots of the llants. One onnce of seed produces about 1000 plants.

\section{Livingston's Mammoth Purple}

(See illustration above of typical fruits grown on "True Blue" trial"grounds.)

This splendid variety we have obtaincd by years of the most careful selection and extra cultivation, beginning with a true strain of New York Improved Large Purple. We now have the finest strain of Mammoth Purple Eg. Plant obtainable. It is quite early for such a large sort, a sure cropper and entirely spineless. The plants are large, vigorous and very productive. The fruit is uniform in color and shape, very, large, usually 6 to 8 inches in diameter, but sometimes specimens are grown measurins 10 inches. Skin, a handsome dark purple, smooth and Selected Seec-

\section{Black Beauty}

From ten days to two weeks earlier than the wurple varieties, and of rich, lustrous, purplish black color, and is a distinct sort and a favorite where known. The plants are remarkably healthy in their growth and yield an abundance of large fruits. The fruit is very attractive in appearance. This variety is entirely spineless. Quality the very best in appearance. This $30 \mathrm{c}$; oz., 50c.; $1 / 4$ ib., $\$ 1.60 ; 1 \mathrm{lb} ., \$ 5.75$.

\section{New York Improved Large Purple}

A leading variety; fruit very large, oval shaped, smooth, deep purple; flesh white and a good quality. The seed we offer is a very fine strain of this popular sort. Pkt., 10c.; 3/2 0z., 25c.;. Oz., 40c.; $1 / 41 \mathrm{~b} ., \$ 1.35 ; 1 \mathrm{~b} ., \$ 1.75$.

\section{Florida High Bush}

A large fruited purple sort; very popular with Southern growers. Fruit is held well up off the ground. A splendid shipper and finds ready sale. The plant is vigorous, guite productive, drought resisting and stands wet weather well. Pkt., 10c.; $1 / 2$ oz., $25 \mathrm{c}$; oz., $40 \mathrm{c}$; $1 / 4 \mathrm{~b}$., $\$ 1.30$; $1 \mathrm{~b}$., $\$ 4.50$.

Mr. Fred Shull, Hocking County, Ohio, writes as follows:

"On account of your being sold out last year 1 had to buy seed from other firms and the result was not satisfactory. I have used your seeds for the last twenty years and they have always been

Mrs. Bate Hyden, McCreary County, Ky., writes as follows:

"I ordered seed from you last year and had good lucls with everything I ordered from you.'

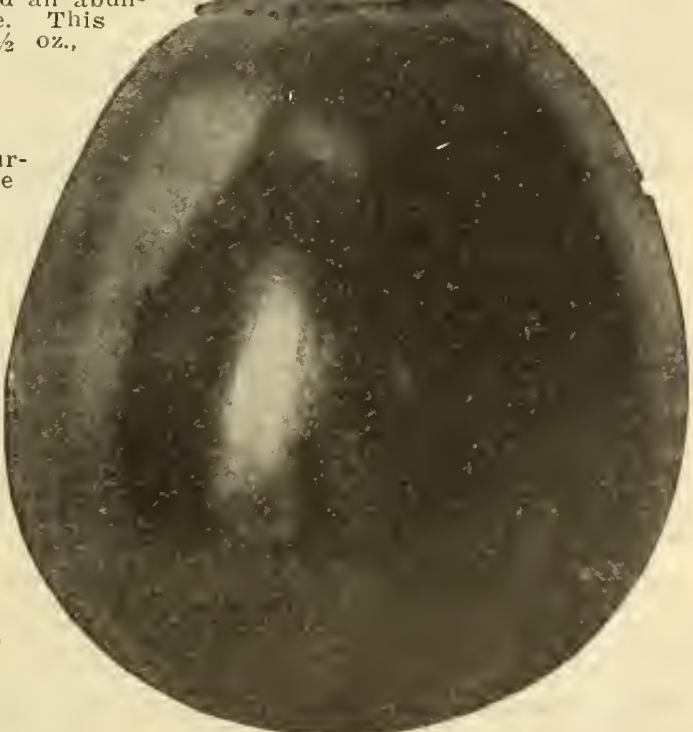

Floricla Fig'l Bush 


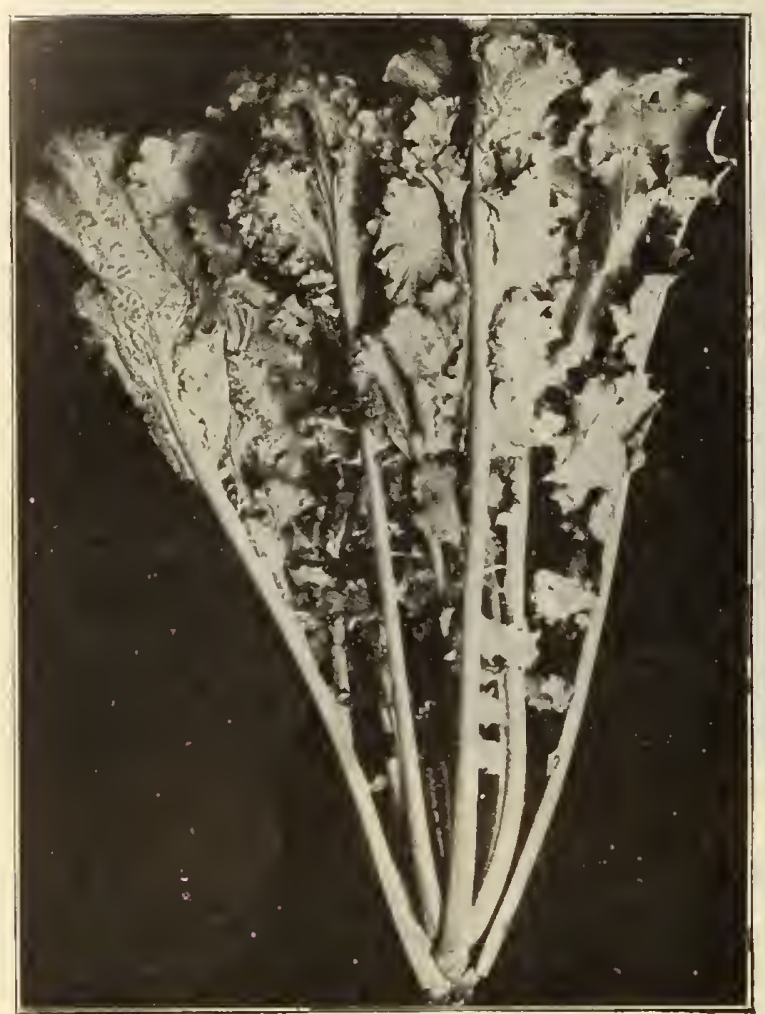

Siberian Kale

\section{Kohl Rabi,(Turnip Rooted Cabbage) \\ Col rabano o Nabicol \\ Bohlrabl}

When Joung and tender they are fine for table use: when matured, they keep splendidly and are excellent for feeding stock. For early use, sow in hotbed, transplant and cultivate like Early Cabbage. For IVinter use plant the middle of June or first of July outdoors in rows 18 inches apart, transplanting or thinning out to 8 inches apart in the rows. One ounce of seed sows 300 feet of drill.

Farliest White Vienna-Greenish white outside, with clear white flesh within. Smooth, short leaf; good for forcing; fine in quality. Pkt., 5c.; Oz., 25c.; 1/4 1b., $70 \mathrm{c}$.: lb., $\$ 2.25$.

Iarlest Purple Vlenna-Same in every respect as the Earliest White Vienna, except in the outside color. Pkt., 5c.; oz., 30c.; $1 / 4$ lb., $85 \mathrm{c}$.

\section{Enaltrien salat Endive Enathia o rsaāiola}

For an early crop, sow in April in drills 15 inches apart, and later thin the plants to stand 12 inches apart in the row. The main sowings are made in June and July. When nearly full orown gather up the leaves and tie them by their tips to blanch them. One ounce of seed will sow 150 feet of drill.

Iarge Curled Pancaller-Erect grower, early, large, ery finely curled, productive and with rose colored ribs. Center so dense that it blanches itself. Plit., 5c.; oz. Pkt., 5c.; oz., 25c.; 1/4 1b., 75c.

Fine Green Curled-Hardiest variety; the most desirable for home use or market garden. Deep green leaves, beautifully cut and curled; easily blanched. (See illustration.) Pkt., 5c.; oz., 15c.; 1/4 1b., 35c.; 1b., $\$ 1.25$.

Iarge Green Curled-A hardy, vigorous growing variety with bright deep green leaves. The dense mass of deeply divided leaves formed in the center blanches very $45 \mathrm{c}$; : 1b., $\$ 1.50$.

Broad Ieaved Batavian-Broad, thick and slightly linkled leaves: form very large heads, which are much used in soups. Pkt., 5c.; oz., $15 \mathrm{c}$.; 1/4 1b., 35c.; 1b., \$1.25.

\section{Breton Kale, or Borecole" Blatterkoh}

Kale, or German Greens, do not form heads, but furnish an abundance of pretty curled leaves that are highly prized as food. Sow from the midale of April to the beginning of May; transplant and cultivate like Cabbage. Will endure considerable frost without injury. One ounce of seed sows 200 feet of drill. 4 pounds sows an acre.

Dwarf Green Curled German Greens, or Sprouts-Is very dwarf and spreading. The leaves are beautifully curled and of a bright green color. Quite hardy. Plkt., 5c.; oz., $25 \mathrm{c}$; $1 / 1 / 4$ 1b., $70 \mathrm{c}$; ; $1 \mathrm{~b}$., $\$ 2.25$.

Siberian Kale-Dwarf growth, bluish green leaves. Sow in September in rows a foot apart, and cultivate the same as Spinach; very hardy and makes an excellent spring

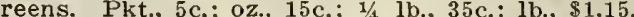

Special Prices made for large quantities of Kale Seed.

\section{Paerro Leeks Porree oder Irauch}

Broad Scotch, or London Flag-A hardy kind; large strong plants with broad leaves. Cultivation the same as for Onions. Pkt., 5c.; oz., 20c.; $1 / 4$ lb., 65c.; 1b., $\$ 2.00$.

Iarge Musselburgh (Carentan or Scotch Champion)Favorite market sort of enormous size: large, broad leaves; flavor is very mild, Pkt., 5c.; Oz., 20c.; 1/4 1b., 65c.; lb., $\$ 2.00$.

\section{Herbs}

Sweet, Pot, Culinary, and Medicinal

Herbs delight in a rich, mellow soil. Sow in early Spring in shallow drills 1 foot apart; cover lightly with fine soil, and when up a few inches thin out, or transplant into prepared beds. Care should be taken to harvest properly Do this on a dry day just before they come into fuli blossom; dry quickly in the shade, pack closely in bottles or dry boxes to exclude the air. Varieties in the list marked with an (*) are perennials.

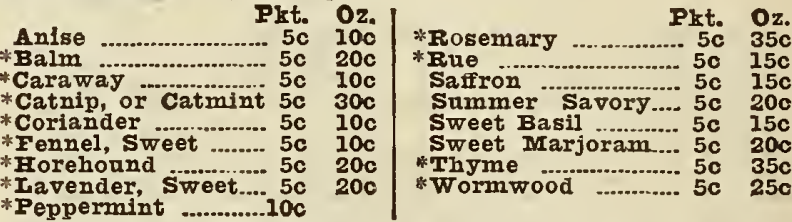

Dlil-This herb is used in large quantities in the malking of Dill Pickles; also for flavoring vinegar. Pkt., $5 \mathrm{c}$. oz., 15c.; 1/4 lb., $45 \mathrm{c}$; ; lb., $\$ 1.50$.

Sage-Sow in rich ground and thin out the plants to stand 15 inches apart. Used for flavorings and dressings. Pkt., 10c.; oz., 50c.; 1//4 lb., 1.75; 1b., \$6.00.

\section{Garlic Sets}

Garlic Sets or Bulbs are planted in early Spring in rows 12 inches apart, placing the sets 4 inches apart in tiplier Onions. Garlic is used for fiavoring purposes. Bulbs, postpaid, oz., $10 \mathrm{c}$.; $1 / 4$ 1b., $25 \mathrm{c}$.

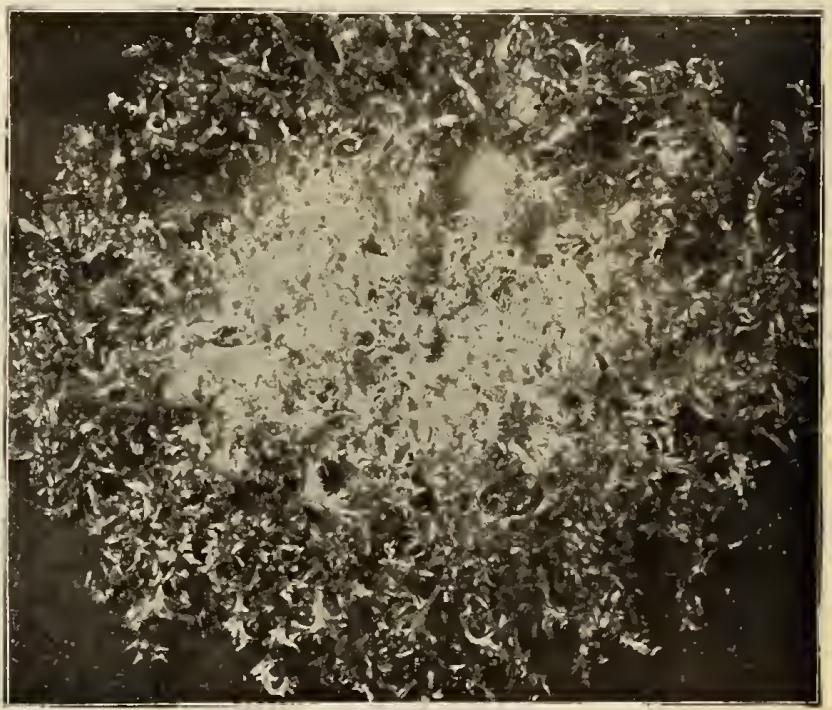

Fine Green Curled Endive 


\section{Lettuce}

Curture-For early Spring use, sow in a seed bed in Sep-. tember or October, and protect through the Winter in coldframes or in the South with leaves or litter, or sow in a hot-bed in early spring. Lettuce plants may also be started very successfully in the house in boxes which are about 5 inches deep. Nake soil very fine and firm. Mark off into rows 2 inches apart and 1 inch deep, into which sow the seed quite thinly; cover with blotting or brown paper fitted into the top of the box. First saturate the paper with water and keep moist until the seed germinates then remove. Expose the young plants gradually to the light. As soon as the ground outside is dry and warm so that it can be well worked, set out the plants 8 inches apart in the rows. For a later supply. sow seeds in the garden every two weeks from the middle of April until Jul choosing varieties according to their heat-resisting Julities. Sow very thinly in rows 18 inches apart, covering seed $1 /$ inch deep with fine soil and when well up thin to 12 inches apart in the rows. In order to have crisp. tender Lettuce, it should be grown as rapidly as possible. therefore the soil should be made very rich by liberal manuring. It is also necessary to keep the soil thoroughly cultivated. Poor soil and lack of cultivation invariably causes poor quality Lettuce One onnce of seed sows 100 square feet; plants 120 feet of row; produces 3,000 plants,

\section{Selected Big Boston (White seeded)}

A very desirable large variety for forcing in cold-frames and for out-door planting. Plants large, hardy, vigorous. Leaves broad, smooth, thin, of a light green color One of the most popular sorts in the South for shipment to Northern markets. It forms good-sized heads and does particularly well during the cool Fall and Spring months. Heads of a pleasing light-green color, frm and of superior quality. When grown in cold-frames, the heads are not as tight as when grown outside. One of the best market varieties we know. Pkt., 5c.; 1/2 Oz., 10c.; 0z., 15c.; 1/4 lb.

\section{The Preferred}

\section{A Black-Seeded Big Boston}

new variety quite similar to Big Boston except as to color of the seed, which in this variety is black, hence more hardy. The heads are large and compact; and the leaves have somewhat less of the slight bronze tinge on the outer edge of the leaves, which is common to the old style of $\mathrm{Big}$ Boston. If this has proven an objection, the Preferred should be found more desirable. Pkt., 5c.; 1/2 oz., 10c.; oz. $15 \mathrm{c}$.; $1 / 4$ lb., $45 \mathrm{c}$.; lb., $\$ 1.50$.

\section{Early Curled Simpson}

A leading early sort; does not head, but forms a compact mass of curly leaves of yellowish green. Matures early; generally grown as an early. crop. $1 /$ Very tendel $\$ 1.75$.

\section{Improved Hanson}

None more reliable for out-door cultivation. Heads grow to a remarkable size, resembling that of a flat cabbage. Extremely slow to run tolled on white and deliciously sweet, tender and crisp. In our trial grounds with dozens of other sorts, it withstood Summer heat among the best. Pkt,, 5c.; 1/2 oz., 10c,; oz., 15c.; 1/1 heat among the bes
lb., 50c.; 1b., $\$ 1.75$.

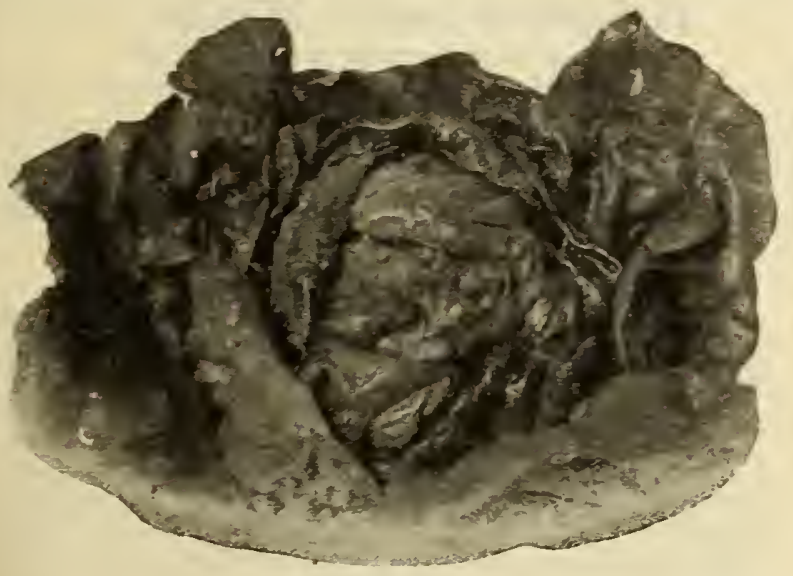

All-Heart

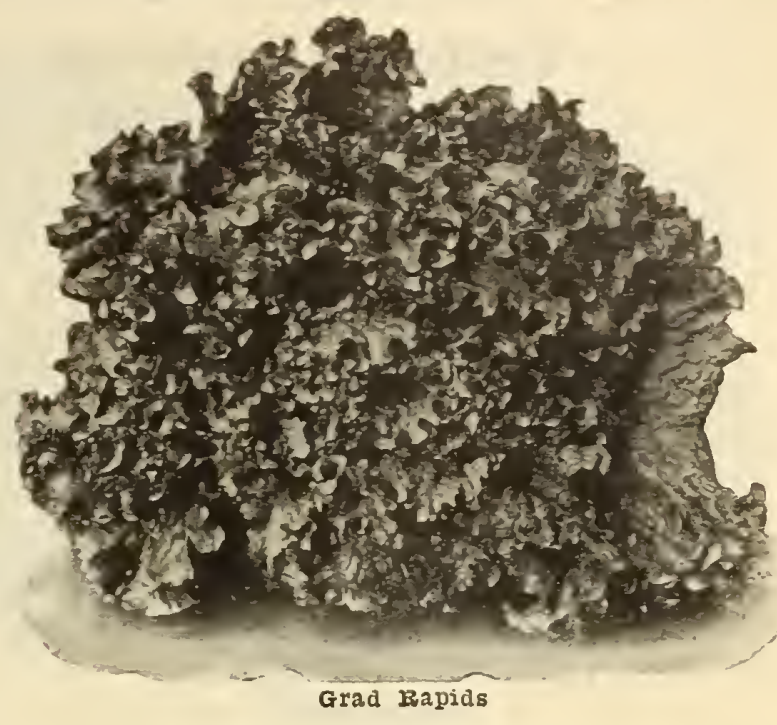

\section{Selected Grand Rapids}

Especially Adapted for Greenhouse Calture in Winter; Also a Good Iettuce to Sow Outside

Early in the Spring

Our Stock of This Variety is Extra Fine and is Greenhouse as Well as outdoor Tested for Purity

Grand Rapids does not form a head, but makes large, compact bunches of light, attractively curlcd and fringed leaves. It grows very rapidly and keeps in good market condition for a long time after cutting. The seed slould be sown more shallow than other sorts, otherwise it may not germinate. Our strain of Grand Rapids is extra fine, before sending out. Pkt., 5c.; 1/2 oz., 10c.; oz., $20 \mathrm{c}$.; $1 / 4 \mathrm{lb}$., 65 c.; 1b., $\$ 2.00$.

\section{Iceberg}

A beautiful Lettuce, with large, curly leaves of a bright light green, with a very slight reddish tinge at the edges. Handsome heads, unusually solid because of the natural tendency to the large, strong leaves to turn in, which flavor. Pkt., 5c.; $1 / 2$ oz., 10c.; oz., $15 \mathrm{c}$.; 1.4 b., $50 \mathrm{c}$; $1 \mathrm{~b} ., \$ 1.75$.

\section{Livingston's Crisp-as-Ice}

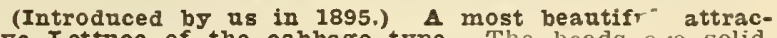
tive Iettrce of the cabbage type. The lieads a se solid, of immense size when well grown, and so exceedingly Iivingston's Crisp-as-Ice. The glossy leaves are thick, nicely crimped and curled; the outside leaves are beautinicely crimped and curled; the outside leaves are beautiheads when cut open, have a rich, creamy yellow heart A superior family and home-market Iettuce, and so hardy as to withstand frost very late in the season. Pkt., 5c.; $1 / 2$ oz., 15c.; oz., $25 \mathrm{c}$.; $1 / 4$ lb., $70 \mathrm{c}$; 1 1b., $\$ 2.25$.

\section{St. Louis Black Seeded Forcing}

One of the best all-round smooth leaved head Lettuces for forcing in cold frames or for planting in the open. Hardy and vigorous grower, heads large, firm, and quality unsurpassed. Leaves broad, smooth and very desirable green color. This variety is one surest to head under all conditions. Unlike many warieties it does not turn brown at approach of cool weather. Grown almost exclusively by the market gardeners of St. Louis. Pkt, 5c.; 1/2 oz., 10c.; oz., 15c.; 1. 1b.,50c.; 1b., \$1.75.

\section{All Heart}

This excellent variety of Lettuce is in favor of both private and market gardeners. It is a ver reliable, hardheading variety of cabbage-lettuce and will give satisfaction wherever grown. It rarely fails to make a large, solid head and is adapted for both Spring and Summer use It withstands heat and forms large heads, leaves closely vellowish-green: weart, even before it is half crown oz., 15c.; oz., 20c.: $1 / 4$ lb., 65c.; $1 \mathrm{~b}$., $\$ 2.00$. 


\section{Lettuce (Continued)}

\section{Livingston's "Bon Ton"}

This fine variety is of the Simpson Lettuce type, but comes almosi absolutely uniform and true. It has a beautiful light oreen outer head, changing to a rich cream shade at the heart. The leaves are just enough wrinkled to make them beautiful, yet not enough so as to render it difficult to prepare them for the table. 'Pkt., 5c.; $1 / 2$ oz., $15 \mathrm{c}$; 0 o., 20c.; 1/ lb., 65c.; lb., $\$ 2.00$.

\section{Unrivalled}

A selection from Big Boston. Heads are large, solid and of a light green color, shading to cleamy white at the center of the head. The quality is fine, having a rich buttery flavor. The Unrivalled is very similar in appearance to Big Boston, but does not have the led tinge at the outer edge of the leaf. Plit., 5c.; 1/2 Oz., 15c.; oz., 20c.; $1 / 4$ lb., 65c.; lb., $\$ 2.00$.

\section{California Cream Butter}

Extra fine sort of this type, forming splendid large, cumpact heads in cool weather. Heads round and solid; outside green; within the leaves are a rich, creamy yellow color; most delicious and buttery in taste. Pkt., $5 \mathrm{c} . ; 1 / 20 z$. $10 \mathrm{c}$; $0 z_{.}, 15 \mathrm{c}$; $1 / 2$ lb., $45 \mathrm{c}$; $1 \mathrm{~b}$., $\$ 1.50$.

\section{May King}

This remarkable variety has proven itself capable of satisfying the most exacting requirements that could be made on an early outdool Lettuce. It is not easily affected by cold or wet weather, grows very quickly and produces, even in poor soil, splendid globular heads, very early in the Spring. Plit., 5c.; 1/2 oz., 10c.; oz., 15c.; 1// lb., $15 \mathrm{c}$; lb., $\$ 1.50$.

\section{Prize Head}

Large heads; even the outer leaves are crisp and tender; light green, tinged with brownish red. Superb flavor: very hardy: very fine for home use; too tender to ship any sreat distance. Pkt., 5c.; oz., $15 \mathrm{c}$.; $1 / 4 \mathrm{lb}$., $45 \mathrm{c}$.; $1 \mathrm{~b}$., $\$ 1.50$.

\section{Deacon}

This Lettuce does not grow as large as some sorts, lout has few outside leaves; grows very solid and of delicious buttery flavor. Center of head blanches to bright yellow shade; very crisp and tender, remaining so for a long time, even in hot weather. One of the fin

\section{Wonderful (New York)}

This splendid mammoth heading and long-keeping variety has been grown to weigh 6 lbs. to the head; frecolor vcly sweet, tender and crisp. Long-standing, perfect heads may be cut from the same bed for many, perPkt., 5c.; 1/2 oz., 10c.; oz., 15c.; $1 / 4$ lb., 50c.; lb., $\$ 1.65$.

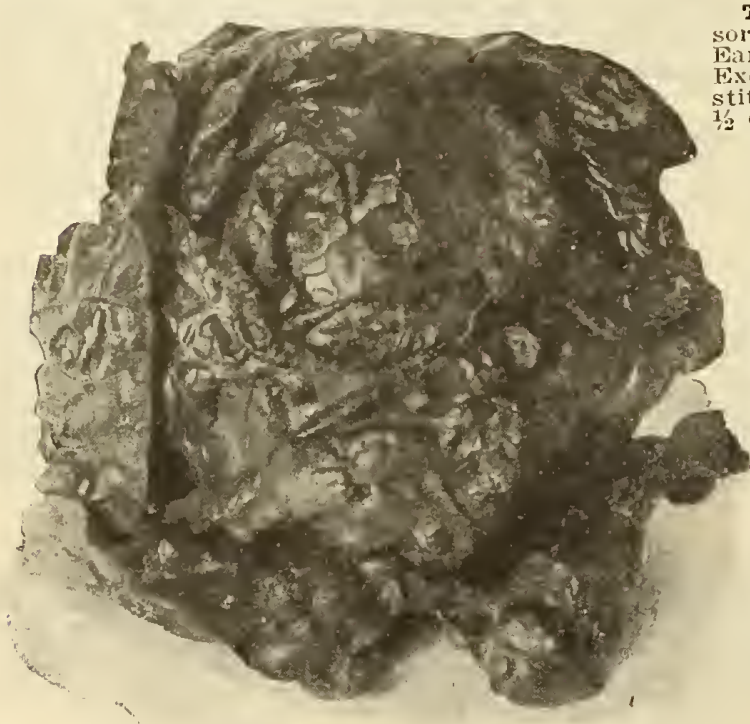

Trianon Cos.-This variety is the finest of the Cos or blanching orts, The long, narrow leaves, which form solid heads, like Warly Jersey Wakefield Cabbages, blanch and become snowy white. Excels in quality and crispness. The leaves, when blanched, are tiff like Celery, and can be eaten in the same manner. Pkt., 5c.:

Is very popular among market gardeners, and fine for the home table. Forms a large, loose head. Its nearly white, curly leaves are large, thin, very tender and of goor quality. Plit., 5c.; 1/2_oz., 10c.; oz., $15 \mathrm{c}$.; $1 / 4$ lb., $50 \mathrm{c}$.; lb.,
$\$ 1.75$.

An early head-lettuce for forcing or open ground. Heads are large, solid and of a desirable light green. Leaves are licious. Pkt., 5c.; 1/2 oz., 10c.; 0z., 15c.; 1/4 lb., 45c.; 1b.

Mammoth Black-Seeded Butter-Heads large, solid, blanching to white at center; leaves smooth, thick, brittle, tender and extra fine flavored. Long standing. Pkt., 5c.; oz., $10 \mathrm{c}$.; Oz., $15 \mathrm{c}$.; $1 / 1$ lb., $45 \mathrm{c}$.; 1b., $\$ 1.50$.

Improved Salamander-Large, compact heads; color light green, shading to white at the center; leaves thick, smooth, tender and of fine quality. Pkt., 5c.; 1/2 Oz., 10c.; oz., 15c."

lb., $45 c_{\text {. }}: 1 \mathrm{lb}, \$ 1.50$

Cabbage, or Phila. Butter-This old reliable variety is very tender, has large, solid, greenish white heads and stands the heat extremely well. Pkt., 5c.; $1 / 2$ O\%, 10c.; oz., 15c.; $1 / 1$ 1b., $45 \mathrm{c}$.; 1b., $\$ 1.50$.

\section{Celery Lettuce}

\section{Livingston's Lettuce Mixture}

\section{One Sowing Produces Salad for the Season}

Contains a grand assortment of decidedly distinct and excellent Lettuces. They mature early, medium and late: some curled and crimped, others produce heads. Colors range from almost pure white, through delicate shade of green and yellow to rich golden. All are delightfully fresh, crisp, tender and of excellent flavor. All sizes, from the small early to the mammoth Summer varieties. Liberal Pkt., 5c.; $1 / 2$ oz., 10c.; oz., $15 \mathrm{c}$.

\section{Special Lettuce Collection $10 \mathrm{c}$}

One full-sized packet each of the following: Selected Big Boston, best head Lettuce; Early Curled Simpson, best curled Lettuce; Deacon, finest "butter head" Iettuce-for 10 cents.

Mr. O. I. Ieed, of Pueblo Co, Colo., writes under date of Oct. 13th, 1918: "Last July I ordered head lettuce seed (Wonderful) of you. Scarcity of labor and other unfavorable conditions prevented it having a fair chance. But with all these drawbacks I am now cutting very fancy stock. I ncver had a crop heading more uniformly or more solidly. "I expect to plant head lettuce very extensively next spring, and wish to know if you can supply a few pounds 


\section{Musk Melons or Cantaloupes}

Melon Almizcleno o Cantain Zucker Melonen

A rich, sandy soil and good seed are absolutely necessary for success in raising the best II uskmelons. The seed should not be planted until the ground sas become dry and warm: plant in hills has become dry and warm; plant well-jot6 feet apart each way old, well-rotwith the soil in each hill and in liberal quantity. Put six to ten seeds in the hill, and when danger from insects is past, leave three or four of the strongest plants only:. MIusk or Cantaloupe I elons may be also sown in rows, that are made about 6 feet apalt, and when are mant ap thinned to stand in hills 5 to 6 feet apart, just before in hills 5 to 6 feet apart, just before insures a good stand of plants in spite of the bugs. Cultivate often and not deep. One ounce of seed will plant 60 hills; 2 to 3 pounds will sow an acre.

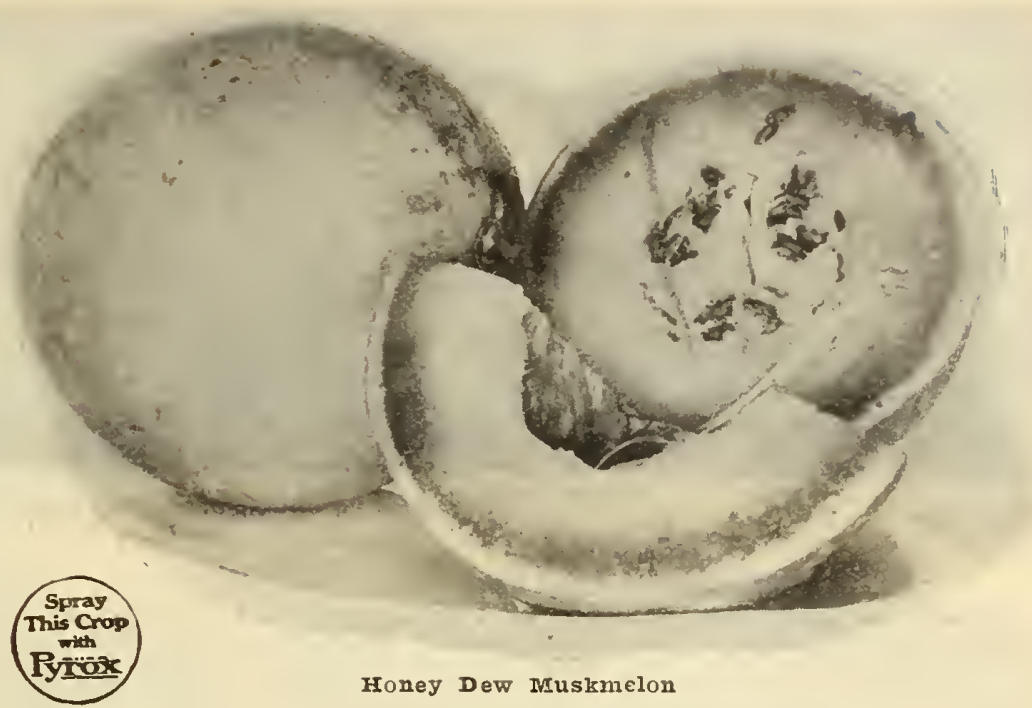

\section{Livingston's Ohio Sugar \\ A Green-Fleshed Tip Top}

Iivingston's Ohio Sugar Melon is an absolutely distinct and very superior Melon. It is the result of caleful hybridizing and painstaking selection and breeding. It is one of the sweetest and most luscious green-fleshed cantaloupes now on the market. It is of that desirable size in demand in all markets; round, inclined to oval in shape heary in proportion to size because the flesh is deep. It heary in proportion to size because the flesh is deep. green Because of its firm flesh and solidity, it is a splendid shipper. Seed cavity is small. It is no lottel. to se lect a good ohio sugar Melon. They are all good. sweet and deliciously clear to the rind. It is the rarest exception that an under-quality Melon is found. The flesh is an attractive green of exquisite texture, susary, juicy, tender, and entirely free from any stringiness. Handsome tender, and entirely free from any stringiness. Handsome and uniform shape; market and home-garden
duces good Melons on a great variety of soils.

The vines are of luxuriant and vigorous growth, yielding bountifully through the season. Pkt., 10c.: oz., 25c. $1 / 4$ lb., 75 c.; 1b., $\$ 2.50$.

\section{Delicious Gold-Lined}

The shape is ideal, being slightly oval, and it is heavily netted over the entire surface. The flesh of the entire Mielon is noticeably thick, fine grained and sweet. The color is green with a gold margin next to the seed cavity Attractive both as to outward appearance and when cut. Pkt., 10c.; oz., 15c.; 1/4 lb., 50c.; lb., \$1.75.

\section{Extra Early Hackensack}

Produces two weeks earlier than the well-known Hackensack; heavily netted, and has light green flesh of most delicious flavor: a splendid Cantaloupe melon. Its shape and solidity admit of its being packed very closely in crates for shipment, and it will keep in good condition for several days after picking. Large, fine form. Plit.

\section{Texas Cannon Ball}

It is slightly larger than the Rocky Ford Cantaloupe. is perfectly round, heavily netted, with no libs, and has the thickest flesh of any melon grown. Flesh is green in color and of good flavor. It has never been used as a shipping melon to any extent, yet the rind is tough and is a good keeper. Pkt., 5c.; oz., 10c.; 1/2 1b., 30c.; lb., $\$ 1.00$

\section{Acme, or Baltimore Nutmeg}

Has a beautiful, heavily netted, green slin; good size shape is oval, slightly ribbed; flesh thick, green, ver finely flavored, smooth. Pkt., 5c.; o\%., 10c.; 1' lb., $30 \mathrm{c}$ lb., $\$ 1.00$.

\section{Osage, or Miller's Cream}

A favorite salmon-fleshed variety. Large, oval, slightly ribbed and netted; skin is very dark green. Flesh is very thick and sweet flavored, most delicious to the rind. The whole crop is very even and fruit extra heavy, owing to this thickness of the flesh. A great favorite for both market purposes and the home garden especially. Pkt. 5c.; oz., 15c.; 1. 1b., 35c.; 1b., \$1.25.

\section{Honey Dew Musk Melon \\ A Delicious New Melon}

1 ts name has been well chosen, as it is about as sweet as Honey. The average size is about six inches in diameter, and they weigh five to six pounds. The skin is smooth with little netting, and of creamy yellow when ripe. The flesh is a beautiful green next to the outside rind shading to light green at the center. It is very thick, melting, fine grained and can be eaten almost to the rind, and the seed cavity is quite small. Pkt., 5c.; 0z., 15c.; 1's lb., 50 c.; 1b., $\$ 1.75$.

\section{Livingston's Rose Gem}

1 fine green-fleshed shipping MTisk Melon named and introduced by us in 1896. In shape it is more oval than the original strain, which gives it additional strength to stand long-distance shipping. One of the best and most profitable extra-early melons in existence for market gardeners and shippers, being especially adapted to basketshipping. Pkt., 5c.; 0z., $10 \mathrm{c}$; $1 / 41 \mathrm{~b} ., 25 \mathrm{c}$; $1 \mathrm{~b} ., 85 \mathrm{c}$.

\section{Burpee's Netted Gem}

This vely early Cantaloupe Melon is one of the most delicious in the whole list. Small and round in shape. Firm, green flesh. Sweet and luscious clear to the rind. Pkt., 5c.; 0z., 10c.; $1 / 4$ lb., 30c.; lb., $\$ 1.00$.

\section{Rocky Ford}

An improved Netted Gem Melon with sweet, green flesh. In the hands of the Rocky Ford (Colorado) growers it has made that state famous in Eastern Markets for melons of unequaled quality. Plkt., 5c.; oz., 10c.; $1 / 41 \mathrm{~b} ., 25 \mathrm{c} . ; 1 \mathrm{~b}$. $85 \mathrm{c}$.

\section{Rocky Ford Pink Meat}

Is quite similar in appearance to an Fien Gem tylue of Focky Ford, being beautifully netted, but the flesh is pink. Its shipping qualities are excellent, quality all that can be desired, and we believe is destined to become popular. Pkt., 5c.; 0z., 15c.; 1/4 1b., 45c.; 1b., $\$ 1.50$.

\section{Davis Grand}

It is salmon-fleshed and is remalkably uniforin in size the color and flavor of flesh are very fine. It sets fruit near the roots, has a more vigorous vine and therefor resists disease better than most sorts. Fruits average about 6 inches in diameter. Plet, 5c; oz, 10c. 1/ $1 \mathrm{~b}, 25 \mathrm{c}^{\circ}$ lb. $85 \mathrm{c}$.

\section{Banana}

Very odd; 18 to 21 inches long. Yellow flesh, blending from briglit green to rich salmon. Fragrant, and one of the most delicious of melons. Early. Plit., 10c.; 0z., 15c.; $1 / 4$ lb., $50 \mathrm{c}$.

All Prices in This Catalogue are Subject to Change Without Notice 


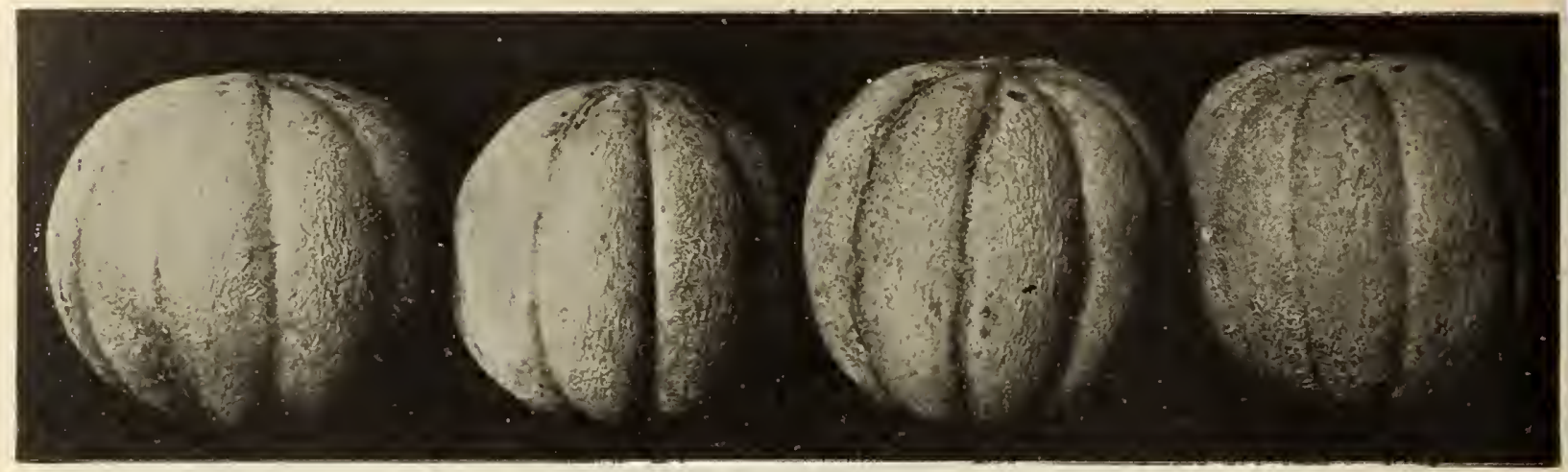

A Row of Iivingston's Tip Tops

\section{Livingston's Tip Top}

TIP-TOP IN QUALITY-TIP-TOP IN APPEARANCETIP-TOP IN PRODUCTIVENESS-Introduced by US in 1892 - This splendid melon has "held its own" for many years against all introductions in the melon line, and no yellow-fleshed melon of which we have any knowledge compares with it in good qualities. The testimony of all who have used Tip-Top is that every melon produced, whether big or little, early or late, is a good one-sweet, juicy, finest flavor, firm (but not hard) fleshed and eatable to the outside coating. Its appearance on the market is very at-
tractive sells on sight. Customers soon learn tractive sells on sight. Customers soon learn
them out and will have no other variety. Fruit to pick them out and will have no other variety. Fruit nearly round, evenly ribbed, moderately netted, very productive. Pkt., $5 \mathrm{c}$.; oz., $15 \mathrm{c}$; $1 / 4$ lb., $45 \mathrm{c}$; $1 \mathrm{~b} ., \$ 1.50$; 5 lbs., $\$ 6.25$.

\section{Hoodoo}

The vine is quite vigorous, resisting bllght better than most other sorts, and is very productive. The fruits vary slightly in shape, averaging nearly round, quite like the Netted Gem. The netting is distinctire in being exceptionally dense and fine, and it extends over practically the entire surface. The rind, although thin, is so very firm that the melons arrive in distant markets in perfect condition. Flesh very thick, highly colored, of finest texture, and delicious flavor. Pkt., 5c.; oz., 15c.; 1/4 lb., 35c.; lb., $\$ 1.10$.

\section{Perfection}

(Princess)-Medium size. Dark green skin heavily netted; flesh a rich orange color; very sweet. Pkt., 5c.; oz., $15 \mathrm{c}$; $1 / 4$ lb., $35 \mathrm{c}$.; 1b., $\$ 1.10$.

\section{Burrell's Gem}

(Ordway's, or Osage Gem)-A superior new orangefleshed shipping melon. Of splendid flavor, sreet and aromatic, oblong in shape, smoothly rounded ends closely netted and slightly ribbed, dark green skin. The rind is thin, but rough; flesh exceptjonally deep rich salmon-orange color. Fruits average 6 by 4 inches Very fine for marketing. Pkt., 5c.; oz., 10c.; $1 / 1$ 1b., 30c.; ib., $\$ 1.00$.

\section{Paul Rose (Petoskey)}

A successful cross of the Osage with the Netted Gem, which combines the sweetness of the one with the fine netting of the other. A large size Netted Gem with deep orange flesh. Early as the Netted Gem. Adapted to shipping in baskets. Originated with an extensive grower of Northern Michigan. Pkt., 5c.; 0z., 10c.; $1 / 4$ lb., 30c.; lb., $\$ 1.00$.

\section{Emerald Gem}

Ripens early: medium size; nearly round: flesh a delicate light salmon color, very thick, fine-grained, and very few melons can compare with it in superb flavor. The rind is thin, dark green, ribbed, slightly netted. One of the best for home use. Pkt., $5 \mathrm{c}$.; oz., 15c.; 1/4 lb., $35 \mathrm{c}$.; $1 \mathrm{~b}$., $\$ 1.25$.

\section{Surprise}

Fruit medium to large size, oval, distinctly ribbed, covered with slight patches of netting: skin light yellow. Flesh salmon color. Pkt., 5c.; oz., 10c.; 1/4 lb., 30c.; 1b., $\$ 1.00$.

We can also offer Early Green Nutmeg, Jenny Iina, Iong Island Beauty, Hackensack, Dwarf or Bush, and Ix. Ea. Green Citron. Pkt., 5c.; oz., 15c.; 1/1 1b., 35c.; 1b., \$1.25.

\section{sandas Water Melons wassermelonen}

A light, sandy soil, with good exposure to the sun, is the best situation to plant Water Melons. The ground should be prepared deep, but receive shallow cultivation. Hoe often and very thoroughly. If extra large Water Melons are desired, for exhibition purposes, leave but one or two on a single vine. Plant in hills 8 to 10 feet apart each way, with a very generous shovelful of well-rotted manure mixed with the soil in each hill. If commercial fertilizer is used, it should contain a large percentage of ammonia and potash. Plant eight or ten seeds in each hill, and finally, when danger from insects is past, thin out to three strong plants. O wing to the large size of water-melon seeds, the ounce size packets are about right for small gardens. One ounce of seed will plant 20 to 30 hills; four or five pounds will plant an acre.

\section{Halbert Honey}

A very sweet, long, dark green variety. Fruits average 18 to 20 inches long, have a thin rind and deep red meat of delightfully delicious flavor; pulp entirely free from stringiness; seeds white. One of the finest for the home garden. Pkt., 5c.; oz., 10c.; $1 / 4$ lb., 25c.; 1b., $85 \mathrm{c}$.

\section{Ice Cream-True White Seeded}

The Great Kitchen-Garden and Home-Market Watermelon-This old standby has too thin a rind for shipping unless packed in straw. Few varieties, if any, surpass a True Ice Cream Watermelon for quality and productiveness. Ours is the original type, very carefully selected and is fancy stock. Of good size, medium early, fruit oblong: rind light mottled green; bright flesh, and solid to the ccnter; melting and delicious. Pkt., 5c.; oz., $10 \mathrm{c}$; $1 / 4 \mathrm{lb}$., $25 \mathrm{c}$. lb., 75 c. By express, not paid: 5 lbs., $\$ 2.50$.

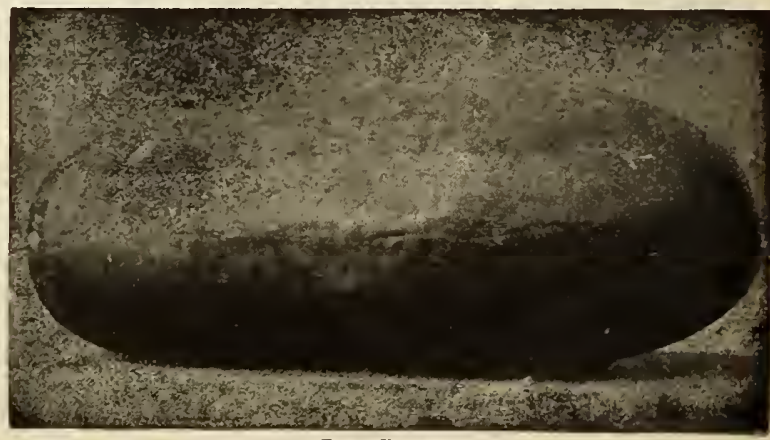

Ice Cream 


\section{Kleckley Sweets}

\section{A Great Melon for Home and} Near-by Markets

This splendid Water Melon has certainly become very popular wherever it has been thoroughly tested. It is of superb, luscious flavor. While the skin is per. haps too thin to admit of the relons being shipped rerr great distances to market, it is most desirable to plant for home use or local markets. The Melons themselves are very large, oblong in form, with dark green skin, thin rind, which is very brittle. and ard splendid 18 to 20 inches in length by 10 to 12 inches in diameter of handsome appearto 12 inches in diameter; of handsome appearlb., 75 c. By express, not paid: 5 lbs., $\$ 3.00: 10$ lbs., $\$ 5.50$.

\section{Irish Grey (New)}

This melon was offered last season for the first, by Southern Seedsmen and we believe is worthy of a place. The vine is very vigorous and holds up well producing fruit until late summer. The rind is greenish grey in color, thin but very tough. Flesh is beautiful red and free from stringiness. Shape and size similar to Tom Pkt., 5c.; oz., 10c.; 1/4 lb., 25c.; 1b., 85c.

\section{Cole's Early}

Tery hardy: a sure cropper for Northern states. Delicate in texture of flesh, which is dark red; rind green, striped with lighter shades, thin and very brittle; of medium size, and nearly round; matures early; especially good for home use. Pkt., 5c.; oz., $10 \mathrm{c}$; $1 / 4 \mathrm{lb}$., $25 \mathrm{c}$.; lb., $80 \mathrm{c}$.

\section{Chilian}

A new white-seeded Melon of fine quality, with a reputation already established in the Pacific states, and will, no doubt, become very popular elsewhere when it is better known. Fruits medium size, nearly round or slightly oblong, skin rich, deep green, indistinctly mottled and fine grained, firm and sweet, quality second to none. A fine grained, firm and sweet, quality second to none, A 5 c.; oz., 15c.; $1 / 4$ lb., 30c.; 1b., $\$ 1.00$

\section{Livingston's Orange}

The peculiarity of this fine Melon is that when well ripened the inner core separates from the rind. Frequently one can lift the entire heart of the Melon out of only The inner portion of the Melon quite resembles a n only Melon is of a beautiful pink shade and fine quality. It grows to a medium size, is productive and, taken altogether, is a very desirable variety. Crop short. Packets $10 \mathrm{c}$. each; oz., $20 \mathrm{c}$.

\section{Kolb's Gem}

Probably the most extensively grown for long distance shipping of any Watermelon ever originated. The flesh is bright red and of good flavor. Melons large, of very thick, oval blocky form; skin handsomely marked in stripes of light and dark green. One of the most productive and best keeping Melons. Pkt. 5c.; oz. 10c.; 1/4 1b., 20c. lb. $65 \mathrm{c}$. By express, not paid: 5 lbs., $\$ 2.50$.

\section{Georgia Rattlesnake, or Striped Gypsy}

Very large, long, smooth and distinctly striped; flesh bright scarlet, very crisp and sweet. Pkt., 5c.; oz., 10c.; $1 / 4$ lb., 20c.; lb., 65c.

\section{Alabama Sweets}

Large, dark green Melons of oblong shape and fine quality; skin fairly netted with lighter green stripes. Flesh bright red, of delicious flavor. A good shipper. Pkt., 5c.; oz., $10 \mathrm{c}$.; 1/4 1b., $20 \mathrm{c}$; 1 lb., $65 \mathrm{c}$.

\section{Peerless}

One of the best for home gardens and market gardeners, who deliver direct to customers. Medium size;

$20 \mathrm{c}$. 1 1b. $65 \mathrm{c}$. 


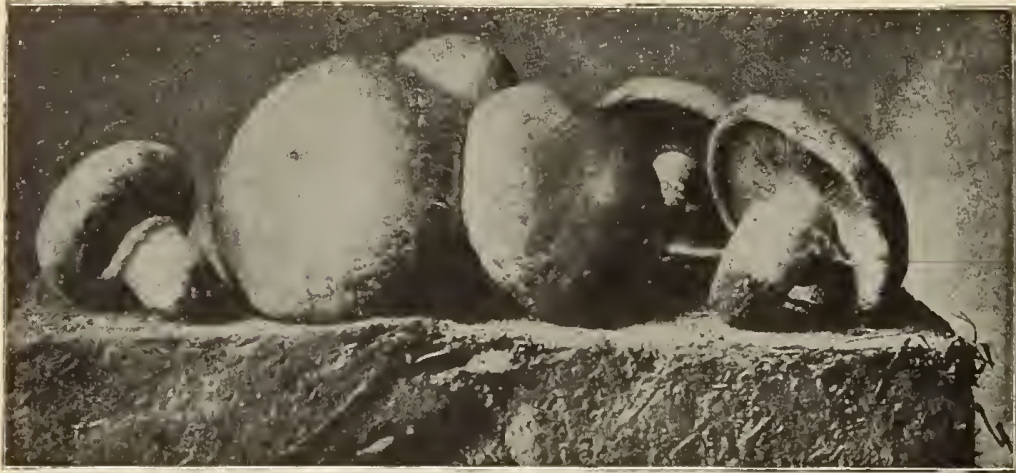

Mashroom Spawn

\section{seta Mushroom Spawn champignoobrat}

Mushrooms will usually do well almost anywhere if a fairly uniform temperature can be maintained. One pound of Spawn is sufficient for a bed $2 \times 6$ feet. We leceive fresh Spawn several times a year from the best makers.

\section{English Milltrack Spawn}

(Iivingston's Sure Crop)-Lb., 25c,, postpaid By express or Parcel Post, at buyer's expense: 5 lbs., 85 c.; 10 lbs., $\$ 1.60 ; 25$ lbs., $\$ 3.75 ; 50$ bs. $\$ 7.00$.

\section{American Pure Culture Spawn}

Produced by the new grafting process from selected and most prolific varieties. Produces a crop very uniform in size and color. Per lb., 35c., postpaid. By express or Parcel Post at buyer's expense: 5 lbs., $\$ 1.10 ; 10$ lbs., $\$ 2.00$ 25 lbs., $\$ 4.75$.

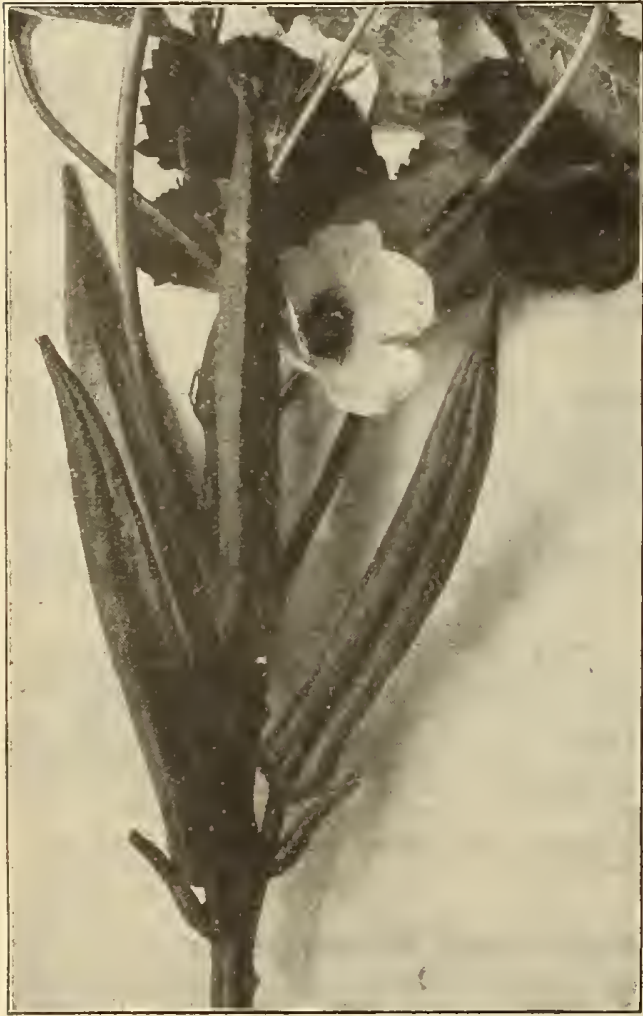

Perkins Mammoth Okra

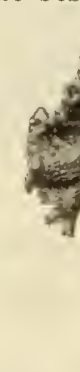

Chinese-A griant leaves double the size leaves double the size quick, almost rank growth, insures tenderness, mildness. and freedom from bitter flavor 10c.; $1 / 4$ 1b., 20c.; 1b., $65 \mathrm{c}$ of you for the senf Mustard mostaza

Used as a condiment; the green leaves are used as a salad, or cut and boiled like spinach. Cultivate same as Curled Cress or Pcpper-Grass. One ounce of seed will sow 50 feet of drill.

Fordhook Fancy-The plants of vigorous growth, have beautiful dark-green curled leaves. It is most productive from early Spring sowings, and stands well even during the hot Summer months. By making several sowings a few weeks apart, a continuous growth of fresh, tender leaves may be had throughout the season. Pkt., 5c.; oz., 10c.; 1/4 lb., 30c.; lb.,

Southern Giant Curled-Is highly esteemed in the South, where the seed is sown in the Fall and plants used early. in Spring as a salad. Seeds brown. in Spring as a salad. Seeds brown. Pkt., 5c.; oz., 10c.; 1/4 lb., 25c.; 1b., $75 \mathrm{c}$.

Mr. Eugene A. Iown, Cheming County, New York, writes as follows: "I was ceived from you last year and will orde. soon for 1919. Pkt., 5c.; oz., 10c.; $1 / 4$ lb., 20c.; 1b.,

White English-Leaves are light green mild and tender when young: seed light vcllow in color. Pkt.. 5c.: 0\%., 10c.: 1/4 1b., 25c.: 1b., 75 c.

\section{Okra or Gumbo}

Very wholesome. The pods, when young, make fine soup. Plant seed after the ground is warm and dry in drills 3 feet apart, thinning the young plants to 1 foot apart. Make early and late sowings to secure a supply throughout the season. Easy to grow in any good garden soil. One ounce of seed will sow 40 feet of drill.

White Velvet-Distinct in appearance; the large pods are perfectly round, smooth, and attractive velvety white, of superior flavor and tenderness. Plant dwarf, of compact branching growth; very prolific. Plkt., 5c.; oz., 10c.; 1/4 1b., 20c.; 1b., 65c.

Perkins' Mammoth-Plant dwarf; is very attractive. Produces beautiful, long, slender, deep green pods, which rcmain tender a long time. in extra choice variety. (See illustration alongside.) Pkt. 5c.; oz.

Rleckley's Favorite-Plants are of compact growth, with many close joints. At each leaf joint develop handsome, smooth, white pods which average 6 inches long, by 1 inch in diameter. They are exceptionally fleshy and tender. Pkt., 5c.; 0z., 10c.; 1/4 1b., 15c.; lb., 50c.

Prices Quoted in This Catalogue are Subject to Change Without Notice

G. S. Seavey \& Son, Penobscot Co., Me., writes, Dec. 13, 1918: “Your seed brought great results for us last year, and we are calling for prices early so we can be sure of getting seed from you this year."

David Bowers, Delaware County, Ohio, writes: "All my order has arrived in fine shape. Thanks for promptness.'

F. Stine, Marion Connty, Iowa, writes: "I have been getting seeds of you for the last forty years and they always give good satisfaction 


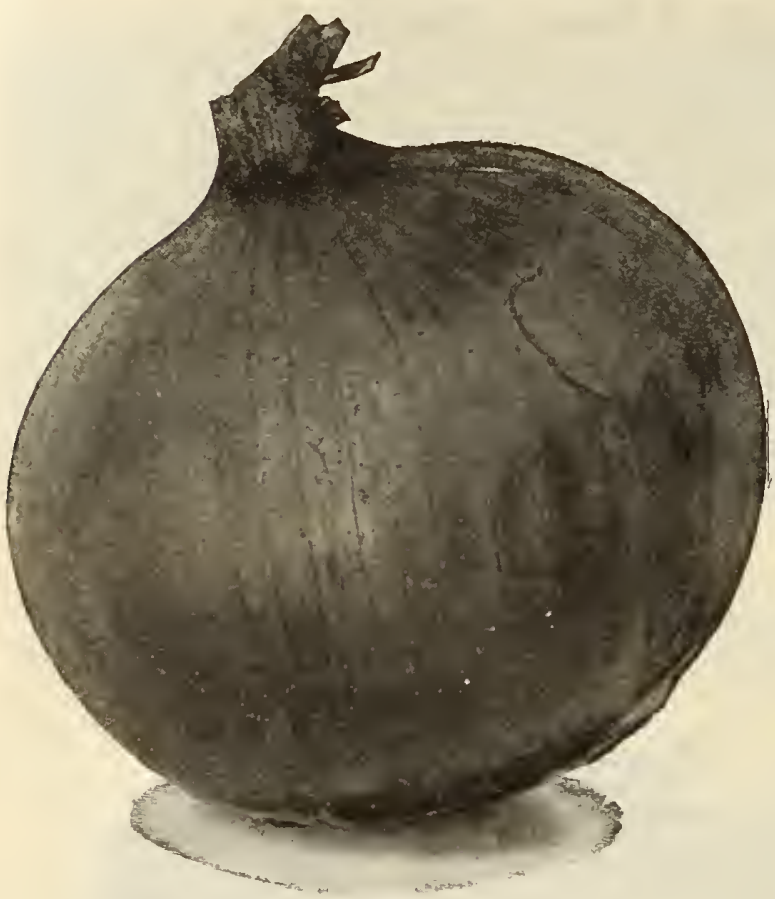

Mammoth Prize-Taker

\section{Mammoth Yellow Prize-Taker}

Enormous size-15 to 16 inches in circumference. Is hardy and a good keeper for such mild flavor. It ripens up firm and very fine grained. Skin rich yellow, flesh white. Has produced more bushels of marketable Onions to the acre than any other variety. Our stock is American grown. Pkt., 5c.: 1/2 o.. 15c.; oz., 25c.; 1//4 lb., 80c.; lb., $\$ 2.75$.

Mammoth Silver Ring-Of attractive shape, with silverwhite skin and flesh of most agreeable flavor. Matures quite early. Matures a larger size than other flat varieties. Pkt., 5c.; $1 / 2$ oz., 10c.; oz., $25 \mathrm{c}$.; $1 / 4$ lb., $85 \mathrm{c}$; ; 1b., $\$ 2.75$.

Extra-Early White Barletta Onion-The very earliest Onion in cultivation. One of the best for pickling, being naturally quite smali. Pure white, mild and delicate. Pkt., $5 \mathrm{c}$; ; oz., $30 \mathrm{c}$.; $1 / 1 / \mathrm{lb}$., $85 \mathrm{c}$; ; lb., $\$ 3.00$.

NOTE-If Onion Seeds are wanted in larger quantitles than quoted herein, ask for our Special Wholesale Prices.

\section{Onion Seeds (Continued)}

\section{Extra-Early Red}

Medium size, very uniform in shape; smaller than Large Red Wethersfield, but two weeks earlier: good keeper; desirable for early market and planting in the North. Pkt., 5c.; oz., $20 \mathrm{c}$.; $1 / 4$ 1b., $65 \mathrm{c}$.; 1b., $\$ 2.10$.

\section{Australian Brown}

This variety has become very popular because of its good keeping qualities. The bulb is medium sized; nearly spherical, being slightly flattened; reddish brown in color and very solid: rather strong flavored. Plit., 5c.; $1 / \mathrm{oz}^{2}, 15 \mathrm{c}$; oz. 25c.; 70c.; lb., $\$ 2.25$.

\section{Philadelphia White Silver Skin}

A good-sized white variety when full grown, and makes a most beautiful, firm, round, nearly white Onion set, for which it is very extensively grown the country over. Pkt., 10c.; $1 / 2$ oz., 15c.; oz., 25c.; $1 / 4$ lb., 80 c.; 1b., $\$ 2.75$.

\section{White Portugal, or Silver Skin}

Matures early: rather flat in shape; mild flavor; excellent for Winter: very much esteemerl for pickling when small. Pkt., 10c.; $1 / 2$ oz., 15c.; oz., $25 \mathrm{c}$; $1 / 4$ 1b., $80 \mathrm{c}$; $1 \mathrm{~b}$., $\$ 2.75$.

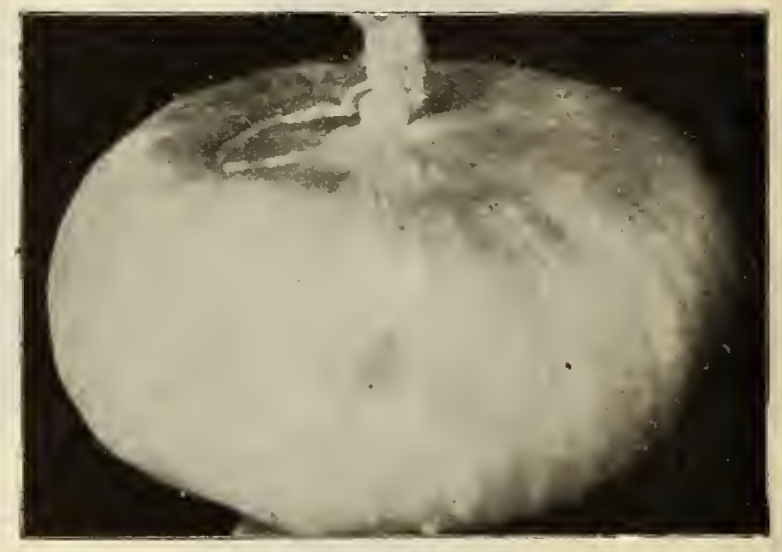

Silver Skin

\section{Indiana Silver Skin}

This is a strain of pure white Onion that produces round, hard Onion sets, for which we highly recommend it to you. The bulbs when fully matured are flat and one of the best keeping white varieties. Pkt,, 10c.; $1 / 2$ oz., 15c.; oz., $25 \mathrm{c}$.; $1 / 1 \mathrm{lb}$., $80 \mathrm{c}$; ; lb., $\$ 2.75$.

\section{Onion Sets}

White Multipliers-Pure silvery-white, enormously productive, frequently 20 bulbs in a cluster from a single bulb. of excellent quality and size for bunching green, or can be ripened for pickling onions. Remarkably good or can be ripened for pickling Onions. Remarkably good lbs., $\$ 2.25 ; 25$ lbs., $\$ 5.50$.

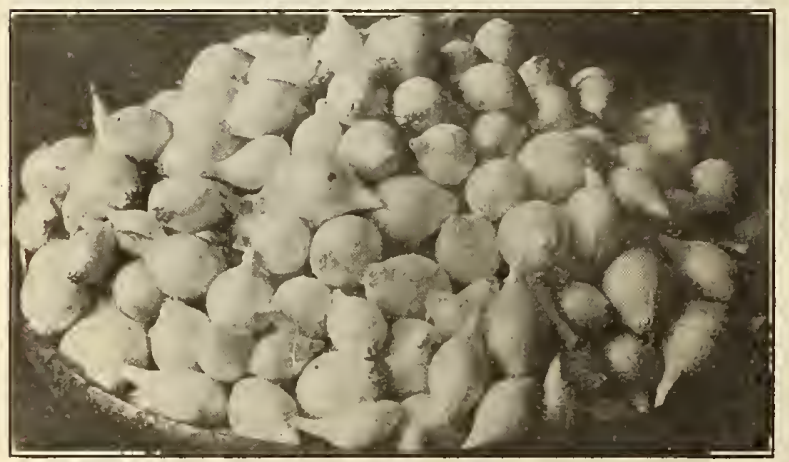

White Bottom Onion Sets

Early green Onions are obtained much earlier by setting out sets than by sowing seed. Some of the latter, however, should be sown to follow the crop grown from the Onlon Sets. Plant both Onion Sets and seed as soon as

the ground is warm and dry in the spring.

Our Set Prices are based on the present market rates It is impossible for us to make fixed prices. Lowest market prices on large or small quantlties will be given on application at any time. A pound of Sets is equal to about a quart measure.

\section{Standard Onion Sets (Bottom Sets)}

Are grown from seed sown very thick in broad, shallow furrows, and covered about half an inch deep. These are the little Onion Sets so much planted for first early Onions. One 'bushel weighs' 32 pounds.

White Bottom Sets-1/2 1b., 20c.; 1b., 35c.; 5 lbs., $\$ 1.25 ; 10$ lbs., $\$ 2.00 ; 100 \mathrm{lbs}$., $\$ 16.00$.

Red Bottom Sets-1/2 1b., 15c.; lb., 30c.; 5 lbs., 85c.; 10 lbs., $\$ 1.60 ; 100$ pounds $\$ 14.00$.

Yellow Bottom Sets-1/2 1b., 15c.: lb., 30c.; 5 lbs., 85c.; 10 lbs., $\$ 1.60 ; 100$ lbs., $\$ 14.00$. 


\section{Perejis Parsley Petersilio}

Parsley is used for seasoning soups and stews, for salads, and is also very universally used for garnishing, also for ornamental borders in the flower garden: succeeds best in a rich, mellow soil. As the seeds germinate very slowly, three or four weeks sometimes elapse before it makes its appearance. It should be sown early in the Spring. One ounce of seed will sow about 150 feet of drill.

\section{Livingston's Exquisite}

One of the main features in any variety of Parsley is the ornamental effect of its leaf when used for garnishing. This is a very strong point in our Livingston's Exquisite, with its very elegant and closely curled leaves of beautiful dark green, while the flavor is all that could be desired. As a pot plant for Winter decoration it is simply "exquisite." The finest strain of Curled Parsley that has ever come under our notice. Pkt., $5 c . ;$ oz., $15 \mathrm{c}$; $1 / 4$ 1b., $50 \mathrm{c}$; $1 \mathrm{~b} ., \$ 1.75$.

\section{Fine Double Curled}

Dwarf, beautifully" curled; very fine variety. Pkt., $5 \mathrm{c}$.; oz., $10 \mathrm{c}$; $1 / 4 \mathrm{lb}, 30 \mathrm{c}$; 1 b., $\$ 1.00$.

\section{Plain}

Much used for soups and stews; rather stronger in flavor than other varieties. Pkt., 5c.; 0z., 10c.; 1/4 1b., 20c.; lb., than
$65 \mathrm{c}$.

\section{Hamburg, or Turnip Rooted}

A rooted variety the fleshy roots resemble Parsnips, and are used in soups and sters. The flesh is white and someWhat similar to Celeriac (Root Celery). The roots may be dug and carried through the Winter lik
Pkt., 5c.; oz., 10c.; $1 / 4$ lb., 30c.; 1b., $\$ 1.00$.

See our Vegetable Collections inside Front Cover Page.

\section{and}

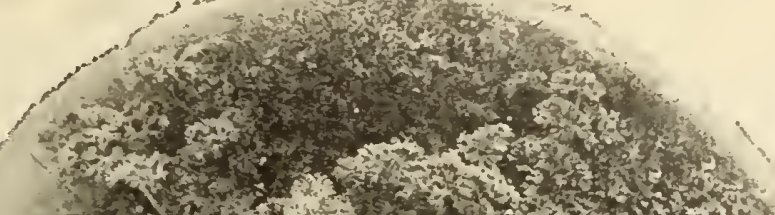

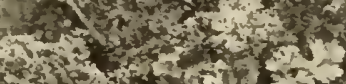

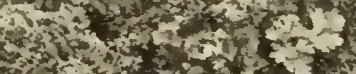

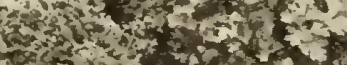
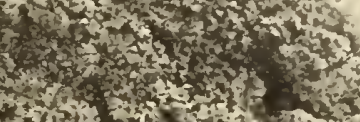

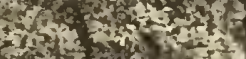

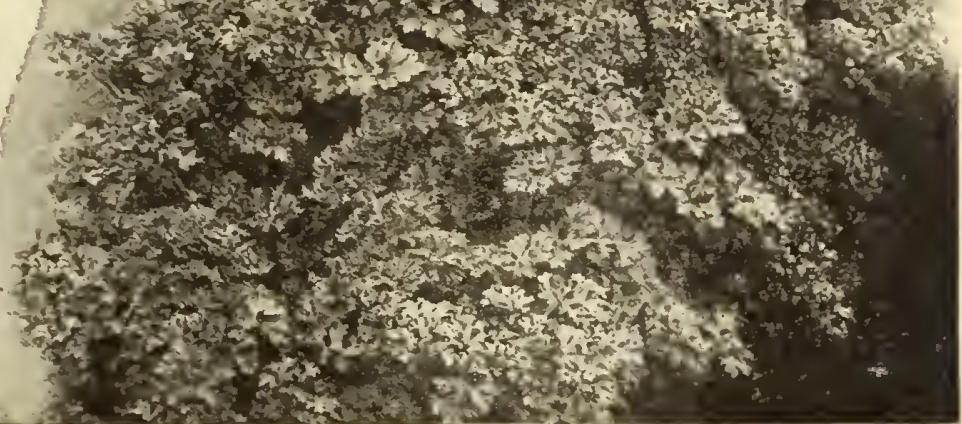

Champion Moss Curled

\section{Champion Moss Curled}

A vigorous, compact sort, very fine for garnishing and flavoring. Owing to its uniformly deep green color and attractive foliage, it is one of the best for either market or home use. More densely crimped and curled than some

Mr. Albext Tilson, Sandusky Co, Ohio, writes as follows: "I received my Seeds in excellent condition last Friday and was well pleased with them. I thank you for your early shipment."

Mrr. C. F. Carrood, Shelby Co., Ind., writes as follows: I have been buying Seeds from you for a number of years and I continue to do so because they always grow."

\section{chiriva Parsnips pastinake}

Sow early in the Spring as the weather will permit in drills 15 inches apart and half an inch deep, in rich, wellmanured ground, well dug. Cultivate similar to Carrots, and thin to 6 inches apart in the rows. The roots improve by being left in the ground until Spring, securing enough in pits or the cellar for Winter use. One ounce of seed to 200 feet of arill, 5 or 6 pounds for an acre.

\section{Large Sugar, or Hollow Crown} (Improved Guernsey)

\section{Long White Dutch}

Roots are very long and smooth; one of the best var1-

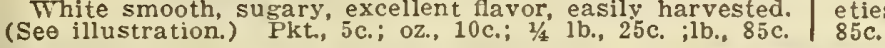

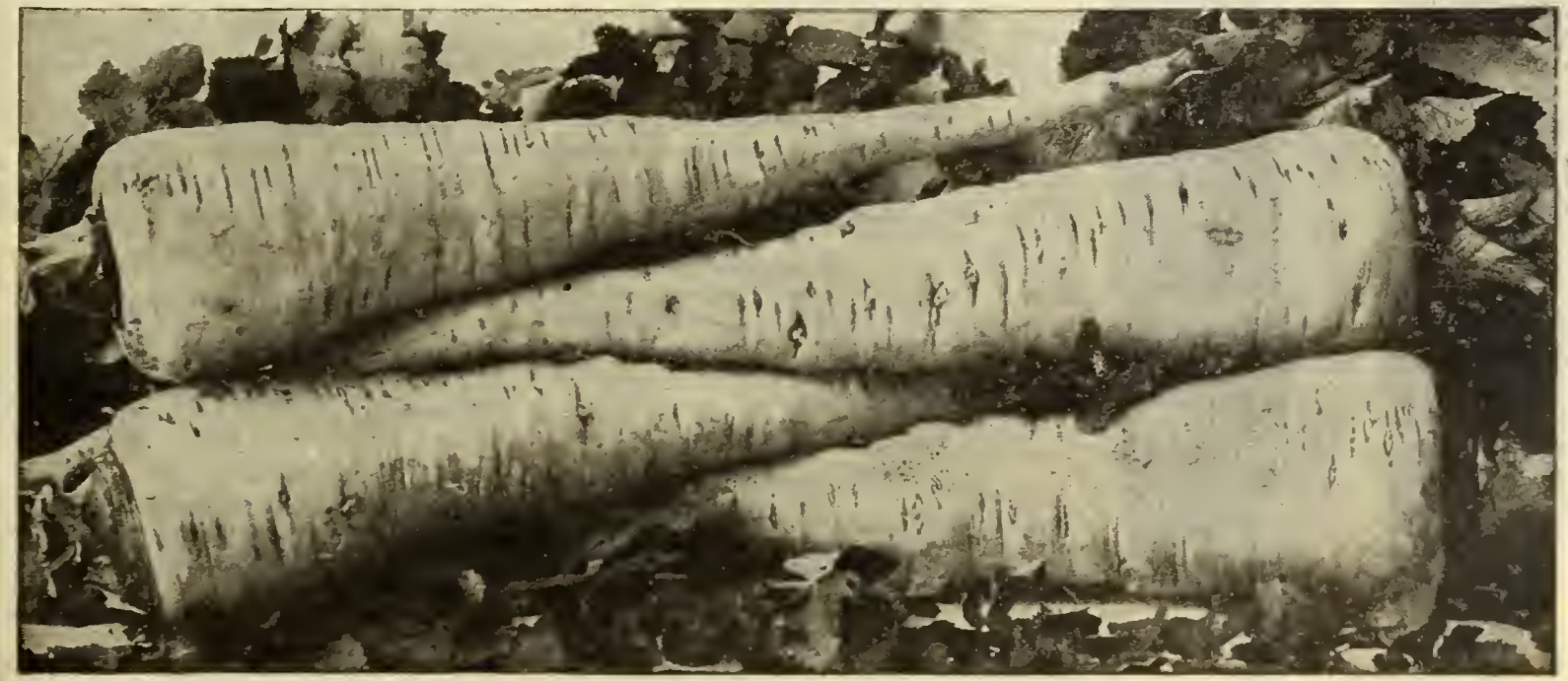




\section{chicaros o Guisantes Garden Peas Irsben}

Peas thrive better if the ground has been manured for a previous crop, but if the ground is poor and requires enriching, use well-rotted manure; and for the dwarf varieties you can hardlv make the soil too rich. When grown as a market crop, Peas are seldom staked or bushed, but are sown in single rows 3 to 4 inches deep, the depth depending on the time of sowing, nature of the soil, as well as the variety. Wrinkled varieties are not so hardy as the smooth sorts, and if planted early should have dry, warm soil, and not planted deep, or they are liable to rot in the ground. These wrinkled varieties are. not planted deep, or they are liable to rot in the ground. These wrinkled varieties are, feet apart, according to the kind, soil and manner of culture desired. When grown in the kitchen garden it is best to sow the seed in double rows, 6 to 8 inches apart, the tall sorts requiring brush. Two pounds sow 100 feet of row; $1 \frac{1}{2}$ bushel for an acre.

\section{Pea Prices}

Our Pea Prices include postage up to and including two pounds. If any of the larger amounts are wanted sent by mail it will be necessary to remit extra to cover postage at the Parcel Post rates.

\section{Livingston's Prolific Early Market}

None of the numerous Extra-Earlies compare with Livingston's Prolific Early Market in length of pod, number of peas in a single plants yield 40 to 50 fully developed peas as the result of one seed sown. The quality is the very best, one of the sweetest and finest flavored of the earliest smooth varieties. Vines grow about 30 inches in height. This sort is the most inches in height. This sort is the most sown, either by the market gardener, canner or in the kitchen garden. Large pkt. $15 \mathrm{c}$.; $1 / 2$ lb., $25 \mathrm{c}$.: $1 \mathrm{~b}_{3 .} 45 \mathrm{c}$

\section{Livingston's First-in-Market}

Excellent variety, very profitable for the gardener and shipper, because it ripens unifornily, so that almost every pod may be gathered at one picking.

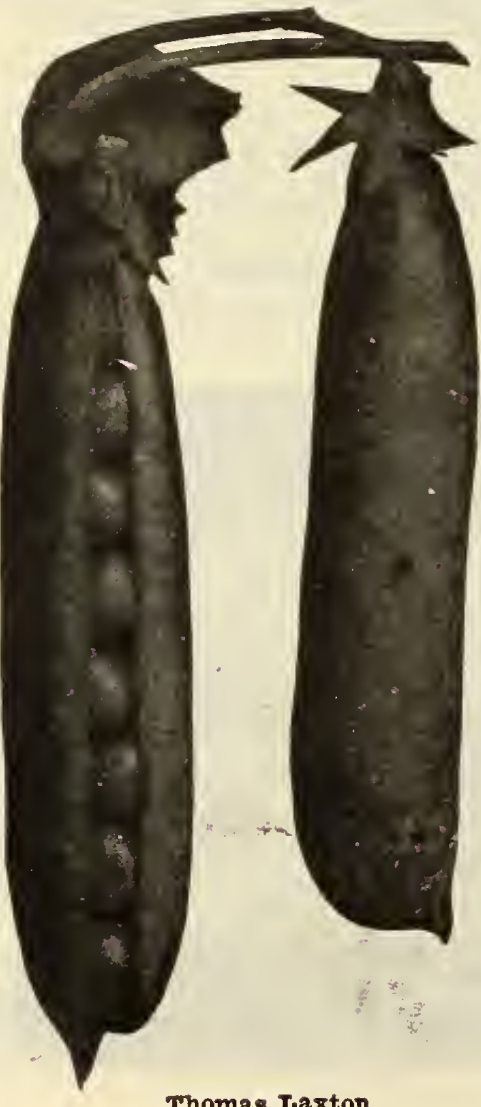
The pods are handsome straight and full of medium-sized round Peas of superior quality; it is immensely productive for such an early sort. Pkt., 15c.; $1 / 2$ lb., 25c.; 1b., 45c.; 2 lbs., 80 c.; 7 lbs., $\$ 1.90$.

\section{Laxtonian}

This is a giant podded, early dwarf Pea-the same size and quality as Gradus, but requires no supports. It is really a dwarf, Early Telephone in size, quality and appearance and all lovers of peas will be well satisfied with it, we are quite sure. Pkt., $15 \mathrm{c}$; $1 / 2 \mathrm{lb}$., $30 \mathrm{c}$; lb., 55c.; 2 lbs., $\$ 1.00$; 7 lbs., $\$ 2.60$.

\section{Nott's Excelsior}

This fine extra-early dwarf wrinkled Pea is very popular. Foliage dark green and rather heavy, suggesting health and vigor. On good soil grows about one foot high. Pods one-third larger than American Wonder and afe all ready to pick at once; a great yielder. Pkt., 15c.; 1/2 1b., 20c.; 1b., 35c.; 2 lbs., $60 \mathrm{c}$.

\section{Thomas Laxton}

The vine grows about 3 feet high, much like that of the Gradus, or Prosperity, but more hardy and greatly more productive. Pods large, long, with square ends, similar to, but larger, longer and handsomer than those of the Champion of England and fully as uniChampion of England, and fully as univery large, fine colored and unsurpassed very large, fine colored and unsurpassed in splendid quality. Pkt., 15c.; $1 / 2$ lb: 14 ibs., $\$ 4.25$; 56 lbs., $\$ 15.50$.

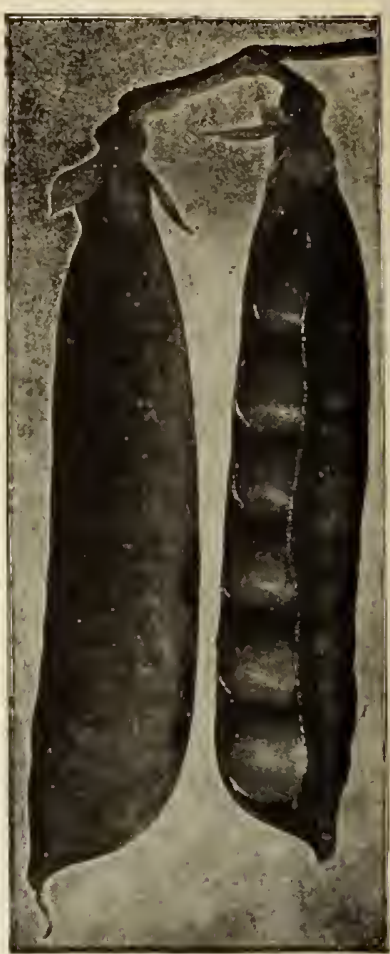

Alaska

\section{Livingston's Selected Extra-Early Alaska}

This fine Pea has become a standard extra-early market variety, and is the earliest of all blue Peas; grows about 30 inches tall; very uniform in maturing the crop. Of good quality and retains that desirable green color after cooking. Our strain is especially fine. Pkt., 15c.; 1/2 1b., 20c.; lb., 30c.; 2 lbs., $55 \mathrm{c}$; 7 lbs., $\$ 1.30 ; 14$ lbs., $\$ 2.25 ; 56$ lbs., $\$ 8.50$.

\section{Little Marvel}

This Pea has been rightly named. It is an early wrinkled Pea with all the good qualities of American Wonder Premium Gem and Nott's Excelsior and some of its own besides. It grows about 15 inches tall and bears heavily. There is no earlier wrinkled Pea and the quality satisfies everybody. Our sales increase yearly because Lit never disappoints. If you are not already using this sort, order it this year. for it is a dandy. Pkt., 15c.; $1 / 2$ lb. $30 \mathrm{c}$. lb., 55c.; 2 lbs., $\$ 1.00 ; 7$. lbs., $\$ 2.60 ; 14$ lbs., $\$ 4.50$.

\section{Premium Gem}

A very fine Extra-Early dwarf Pea of Little Gem type, on which it is a decided improvement; pods are larger and more productive. Pkt., 15c.; 1/2 lb., 25c.; 1b., 45c.: 2 lbs., 80c.; 7 lbs., $\$ 1.90: 14$ lbs.. $\$ 3.50$.

Wm. Rommel, Midalesex Co, $\mathbf{N}$. J., writes, March 11, 1918; "I am a market writes, March 11, 1918: "I am a market gardener selling to retail private trade. Last vear we had your Premium Gem but not enough. Also your Early Sugar Corn was very fine."

All Prices Quoted in Phis Catalogue are Subject to Change without Notice. 


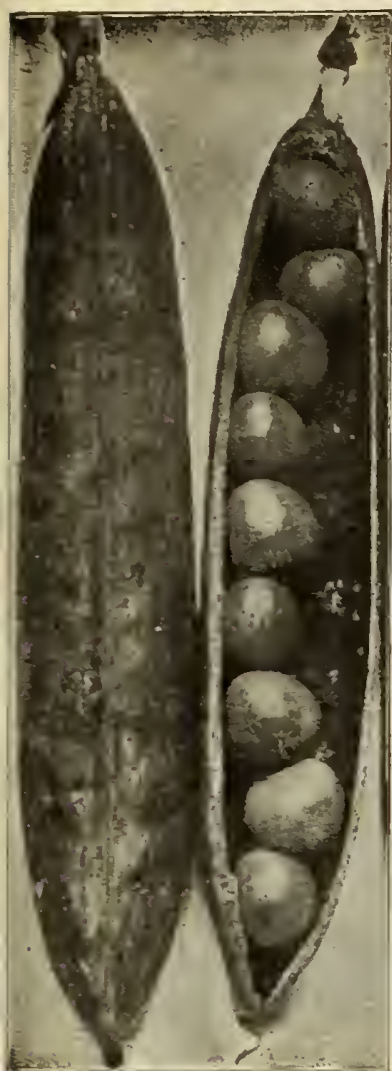

Gradus or Prosperity

\section{Pioneer}

A new large podded early Wrinkled Pea of great promise. The vines are extremely vigorous, growing 15 to 18 inches high, dark green and produce a wonderful crop of dark green pods which are filled with big Peas of delicious flavor. It is one of the earliest Wrinkled Peas, coming about the same season as Gradus, but a heavier cropper. At this time we have the promise of a good delivery on this variety and we hope to fill all orders in full. Pkt., 15c.; 1/2 1b., 30c.; 1b., 50c.; 2 lbs., 90c.; 7 lbs., $\$ 2.50$; 14 lbs., $\$ 4.30$.

\section{Peter Pan}

A very promising new early sort with big Dark Green pods and peas. Produces large pods filled with peas of highest quality. It has vigorous growing large dark foliage standing about 15 to 18 inches in height. The Peter Pan Pea is the "last word" in this class of large podded dwarf growing dark green foliage, pods and Peas. Pkt., 15c.; $1 / 2$ lb., 30c.; 1b., 50c.; 2 lbs., 90c.; 7 lbs., $\$ 2.50$.

\section{Sutton's Excelsior}

A fine wrinkled Pea, quite hardy and may be planted with the hard-seeded varieties. The plants are dwarf (about 15 inches high), of vigorous growth and productive. ity is all that could be desired. Sutton. produces larger and broader pods than most early varieties, and it matures within a few days of Nott's Excelsior. It is a desirable variety for home and market use. Pkt., 15c.; $1 / 2$ 1b., 30c.; 1b., 55c.

\section{Gradus or Prosperity}

(See illustration.) This extra fine variety combines earliness with large size in a green wrinkled Pea. In earliness the Gradus follows closely after the First Earlies, being only two to three days later than Livingston's First-in-Market. In height they grow about $2 \frac{1}{2}$ feet. The pods are long and straight; and well filled with luscious sweet peas of superb quality. It produces most uniformly large pods, measuring 4 to $4 \frac{1 / 2}{2}$ inches in length, and well filled with large, handsome Peas. Pkt., 15c.; 1/2 1b., 25c.; 1b., $45 \mathrm{c}$ : 2 lbs., 80c.: 7 lbs.. \$1.90; 14 lbs., $\$ 3.50 ; 56$ lbs., $\$ 13.00$.

\section{Livingston's Home Collection of the Three Best Peas for the Private Garden}

The varieties contained in this collection are all superior sorts-sweet, tender and delicious. It contains early, medium and late sorts, and will supply the table with a succession of luscious Peas for a long period.

Prolific Early Market-For length of pod, number of Peas to the pod, and number of pods to the vine, it is a wonder.

Gradus-Produces most uniformly large pods, medium early.

Potlatch-A large dark podded sort. 8 to 9 Peas to the pod; fine quality.

Ono 15c. packet each of 3 Best Peas, 400; I lb. each, \$1.10, not prepaid.

\section{McLean's Advancer}

The leading Pea for second early. Excellent flavor, very productive. It is a wrinkled variety, grows about two feet in height Has long pods, and well filled to the end. Ripens so uniformly that the vines can usually be picked clean in two pickings. Pkt., 15c.; 1/2 1b., 20c.; 1b., 35c.; 2 lbs., 60c.; 7 lbs., $\$ 1.50$; 14 lbs., $\$ 2.75$; 56 lbs., $\$ 10.00$.

\section{Alderman}

The Alderman is a late wrinkled variety growing four to five feet high and bearing freely, large pods of a dark green color. These pods each contain eight or nine large dark green Peas of unsurpassed flavor. Pkt.; $15 \mathrm{c}$; ; $1 / 2$ 1b., $25 \mathrm{c}$; ; lb., $45 \mathrm{c}$.; 2 lbs., 80c.; 7 lbs., $\$ 1.90 ; 14$ lbs., $\$ 3.50$.

\section{Potlatch}

A variety of great value, growing 15 to 18 inches high, with very large pods. measuring up to 6 inches in length. Vines and pods are a rich, dark green, and pods contain 8 to 9 immense Peas. The plant is a vigorous grower, the pods being borne in pairs. It is a great producer and the quality of Peas which shell out in surprising. Pkt., 15c.; 1/2 1b., 25c.; lb., 45c. 2 pribs., 80 c.: 7 lbs., \$1.90; 14 ibs., $\$ 3.50$; 56 lbs., $\$ 13.00$.

I. H. Pearson, Perry Co., O., writes: "Enclosed find $\$ 1.00$ for which send us your 'Great Dollar Vegetable Collection. Please send Sweet Peas-your own selection. We have bought your True Blue Dollar collections nearly every year and find them very good."

See Our Dollar Collection Offer inside Front Cover
Improved Stratagem

nes are strong, vigorous and covered with immense pods, many of which
measure nearly $5 \frac{11}{2}$ inches in length and containing as high as ten large, richly flavwrinkled Peas. The quality is excellent. Pht., 15c.; 1/2 1b., 25c.; lb., 45c.; 2 lbs.,

Carter's Telephone-The favorite late variety for the market gardener. Extra large pods. Vine large, coarse leaves, heisht about 4 feet. The pods are

Champion of England-An old variety, but considered by many the best tall ing sort. To do its best it needs support. A prolific bearer of large pods, ( 2 lbs., 80c.; 7 lbs., $\$ 1.90 ; 14$ lbs., $\$ 3.50$.

's Prolific Giant-Podded sugar. Iivingston's Prourcer Peas. in size, pro3 to 4 feet in height. The pods are gigantic in size, broad, sweet and tender extremely for cooking pods and all. Pkt., 10c.; $1 / 2$ lb., 20c.; 1b., 35c.; 2 lbs., 60 c. ; 7 Ibs., $\$ 1.25$; $15 ; 56$ lbs., $\$ 8.00$.
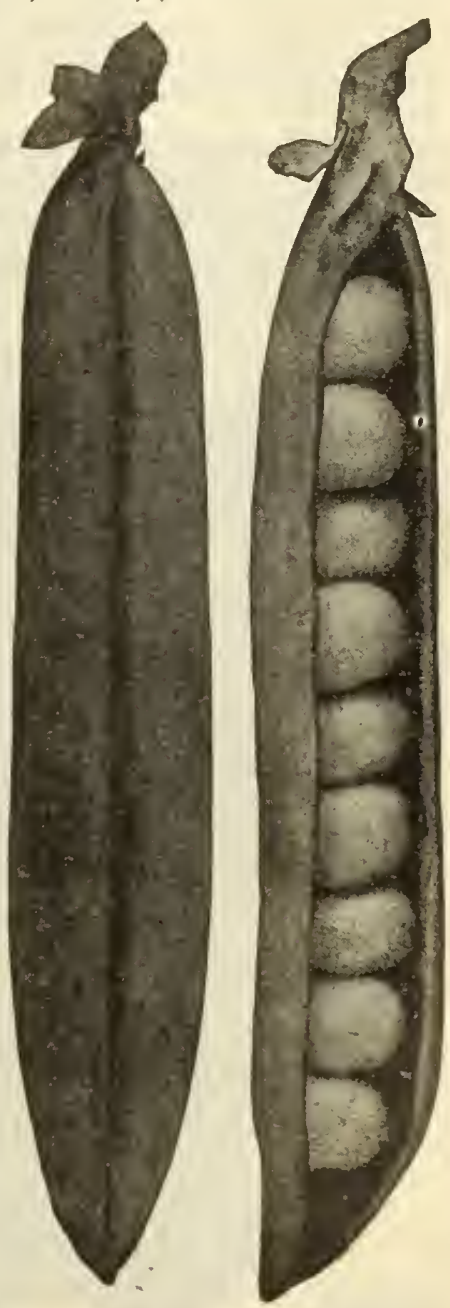

Potlatch 


\section{Pimento Choice Peppers preffor}

Peppers should be started in a hotbed or cold frame and transplanted about the end of May into a sunny corner of the galden, in rows about 2 feet apart, with the plants about the same distance between them in the rows. They can also be sown in open ground in a prepared seed bed when all danger from frost has passed and the weather has become settled and the soil warm. When the little plants are about 3 inches in height, transplant as above into the rows where they are to remain. Some very rich fertilizer stirred into the soil when the plants are about 6 inches high, will be found crop. The peppers intended for mangoes should not be grown near the hot varieties, as if so they will partake of their fiery nature. One ounce of seed will produce about 1500 plants.

\section{Livingston's Ohio Crimson}

The Sweetest and Biggest Mango Pepper

(Introduced by us in 1906.) Habit of growth, robust and stocky, and a sure cropper. The fruit is extra large. In weight Livingston's Ohio Crimson is much heavier than other varieties, owing to thicker flesh. In flavor it is the mildest we have ever known as the flesh, and even the seeds may be eaten from the hand without any of the fiery sensation. Growers tell us their customers prefer it to others for making mangoes. Pkt., 15c.;

\section{Sweet Salad Pepper}

(Pimento)-Also Known as Perfection-This Pepper is especially desirable for canners. It is also fine for the home garden, both green and ripe. It is so smooth and uniform in shape that the skins can be easily slipped off after burning over a hot fire for a few seconds or by boiling a few minutes in hot water. The meat is from two to three times as thick as that of others. Quality very sweet and delicious and entirely free from pun-
gency. Color when ripe a beautiful scarlet red, Very productive, yielding heary crops until cut off by frosts. It is largely, grown by canners for pimentos, pickles and pulp. Pkt., $10 \mathrm{c}$; $1 / 2$ Oz., $25 \mathrm{c}$.; oz., $45 \mathrm{c}$.; $1 / 4$ lb., $\$ 1.40$; $1 \mathrm{~b}$., $\$ 5.00$.

\section{Royal King}

A new thick-meated Pepper of the Ruby King type. See specialty pages for description. Pkt., 15c.; 1/2 oz,, 25c; oz., $45 \mathrm{c}$.;

\section{Tomato Shaped Pepper (Fimento) Very Thick-Meated and Mild}

This very popular variety used extensively by the Spanish people in their Pimento salads. It is a thick meated variety of mild flavor, being brilliant red in flesh, and very productive. Pkt., $10 \mathrm{c}$; $1 / 2 \mathrm{Oz} ., 25 \mathrm{c}$; $\mathrm{oz}$., flesh, and very prod

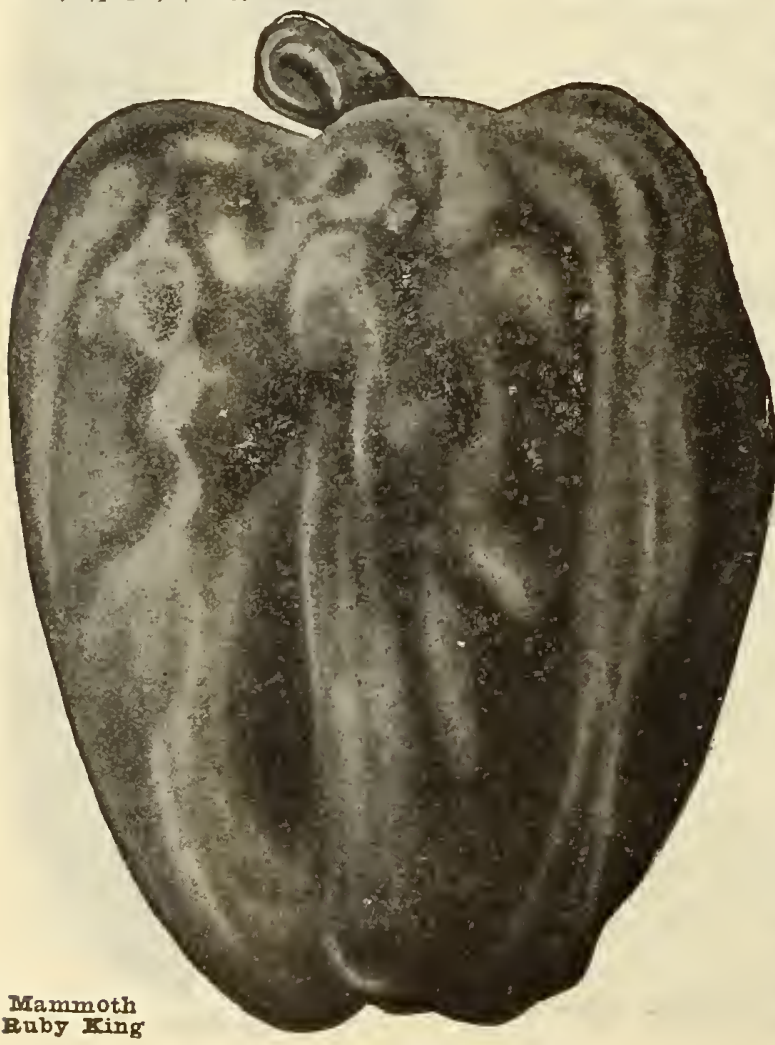

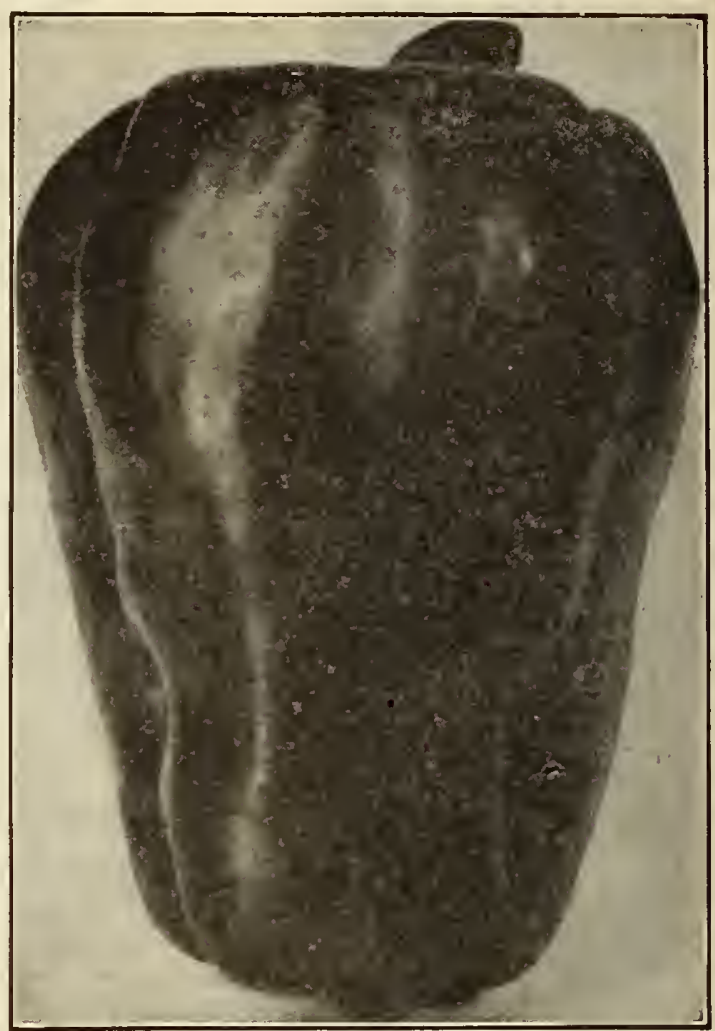

Ilving'ston's Prollfic Yellow Pepper

\section{Livingston's Prolific Yellow Pepper}

\section{VERY EARIY, VERY PRODUCTIVE, VERY MIID}

Introduced by Us in 1914. (See lllustration above.)

Immensely productive, of bright yellow fruits of the most convenient size for stuffing. Comes into bearing much sooner than the mammoth sorts, and is the surest crop of all. It may be used for stuffing while yet green. We secured a small amount of the seed of this variety some years ago from on $\theta$ of our gardener customers and after carefully selecting it so as to produce fruits true to type, we offered it for the first time in 1914 .

On account of the mildness and thick walls of Livingston's Prolific Yellow Pepper, it is one of the finest for use in salads or pickles. Pkt., 10c.; $1 / 2$ oz., 30c.; oz., 50c.; 1/4 1b., $\$ 1.75 ; 1 \mathrm{~b}$., $\$ 6.00$

\section{World Beater}

Said to be a cross between Ruby King and Chinese Giant. The shape is like Ruby King, only the blossom end is broader. and the size nearly equal to Chinese Giant. The plant is a strong, vigorous grower and very prolific. The fruit is a beautiful scarlet in color and exceedingly mild. The flesh is thick and firm, making this variety an excellent shipper; very popular in the South. Pkt., 10c.; $1 / 2$ oz., $25 \mathrm{c}$; $02 ., 45 \mathrm{c}$; $1 / 4 \mathrm{lb}$., $\$ 1.50 ; 1 b ., \$ 5.50$.

\section{Neapolitan}

This is the earliest of the large mild red Peppers grows about about four inches long and three inches in diameter. Worthy of a place in every garden. Pkt., 5c.; $1 / 2$ oz., $25 \mathrm{c}$; oz., $45 \mathrm{c}$.; $1 / 4 \mathrm{lb}, \$ 1.50$.

\section{Mammoth Ruby King}

Our Mammoth Ruby ring Pepper is one of the largest and finest mild Red Peppers in cultivation Not only is it very productive for so large a Pepper but its splendid size and productive for so large a Pepper, but its splendid size and ket, and for the kitchen garden it is a special feature. The plants are vigorous, stocky and dwarf; very bushy, growing about 2 feet in height. They are well branched; thickly set With large fruits, some 5 to 6 inches long by about 3 inches thick. When ripe they are of a beautiful bright, glossy red color, and are always remarkably mild and pleasant to the taste. They can even be sliced and mild and pleasant to the gar (like Tomatoes or Cucumbers) and are most appetizing. gar (like Tomatoes or Cucumbers ), and are most appet
Pkt., $10 \mathrm{c}$; $1 / 2$ oz., $300^{\circ}$.; oz., $50 \mathrm{c}$.; $1 / 4$ lb., $\$ 1.75 ; 1 \mathrm{~b} ., \$ 6.00$.

Susie A. Weinkert, Guernsey Co., Ohio, writes, Jưly 11, 1918; as follows: :We have been using your seeds for over 20 years and they are superior to all of the others we know anything about." 


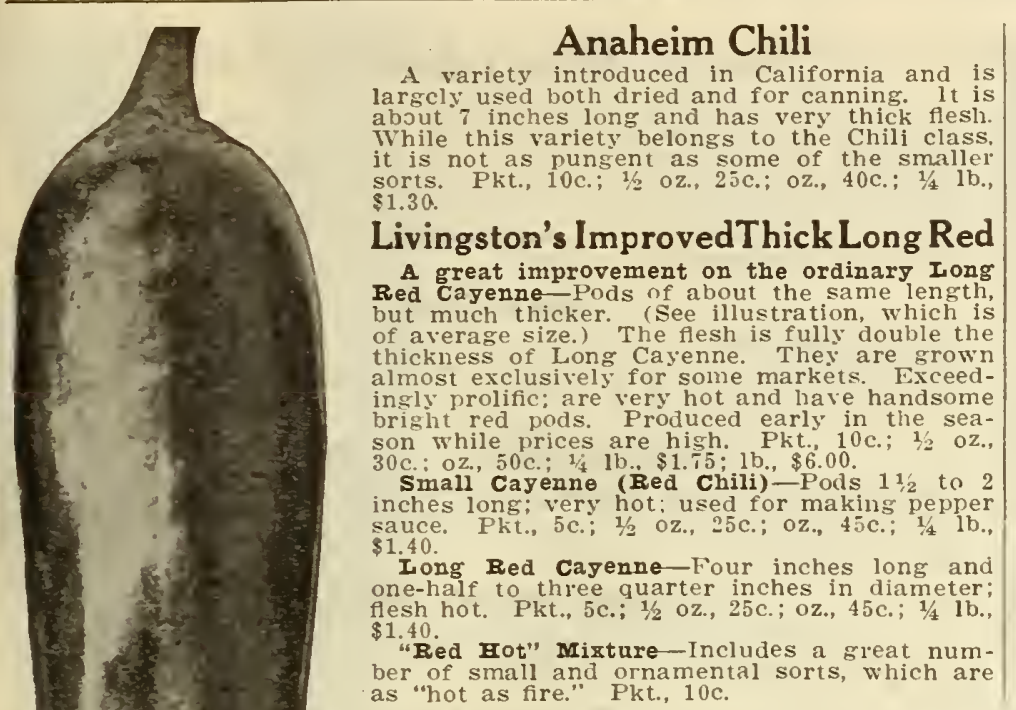

\section{Chinese Giant}

It is of mammoth size, splendid shape, beautiful rich, glossy bright red flesh and mild flavor. Its strong, bushy plants, which are loaded with the splendid large fruits, begin bearing quite early. Has few sceds, hence necessarily high in price. Pkt., 15c. 1/2 oz., 35c; oz., 65c.; 1/4 lb., \$2.25.

\section{Large Bell, or Bull Nose}

An early variety and of mild flavor except in hot, dry seasons. The skin is quite thick and fleshy; of medium size; is quite $25 \mathrm{c}$; Oz., $45 \mathrm{c}$.; $1 / 1$ lb., $\$ 1.50$; $1 \mathrm{~b}$., $\$ 5.50$.

\section{Sweet Mountain}

Very similar to Bell or Bull Nose; sweet and mild flayored; used for stuffing. Pkt., $\$ 5.25$.

Mixed Mango Peppers-A choice mixturc, containing a verv large number of varieties suitable for stuffing and mangoes. Pkt., 10c.

\section{calatazass Livingston’s Prize Winning Pumpkins}

Pumpkins are not so particular in regard to soil as Melons or Cucumbers, but in other respects are cultivated in a similar manner. Sow in the month of IIay, when you plant your corn. Make hills, the same as ynu do for Squashes, but aboot 8 to 10 feet apart each way. It is vreferable to grow Pumpkins in the field, and not in the garden, as they always nix with the Squashes and other vines. You can sow some amongst your late corn, putting in a few seeds, say every third or fourth hill This will sive you plenty for the table, and your stock the coming Winter. One ounce of seed will plant 15 hills; 3 to 4 lbs. plant an acre.

\section{Small Sweet or Sugar}

This is the small, sweet Pumpkin that has made the New England States famous for their pumpkin pies. It is a very fine-grained, most deliciously sweet-flavored sort. Splendid

keeper. They average about 10 inches in diameter. Deep Improved Thick Iong orange-rellow color. Pkt., 5c.; 0z., 10c.; 1/4 1b., 30c.; lb., $\$ 1.00$ Red Pepper

\section{Large Sweet, or Kentucky Field}

Large, round,. flattened, hardy and productive. One to two feet in diameter. It has thick flesh of extra fine quality and is a splendid sort for canning, family and market use; and uscd largely for stock feeding. Pkt., 5c.: oz., 10c.; 1/4 1b., 25 c.; 1b., $75 \mathrm{c}$

\section{Common Yellow Field}

Yankee Cow Pumpkin, or Connecticut Field-The common Yellow Field Yankee Cow very largely cultivated by our farmers for stock feeding, and used some for canning; very productive. Pkt., $5 \mathrm{c}$. : 0z., $10 \mathrm{c} . ; 1 / 4$ b., $20 \mathrm{c}$.; 1b., $65 \mathrm{c}$, Japanese Fie-Crooked neck; quality fine; very productive; ripens early; Japanese Fie- Pkt., 5c.; oz., $15 \mathrm{c}$.; $1 / 4$ lb., $35 \mathrm{c}$.; $1 \mathrm{~b}$., $\$ 1.10$.

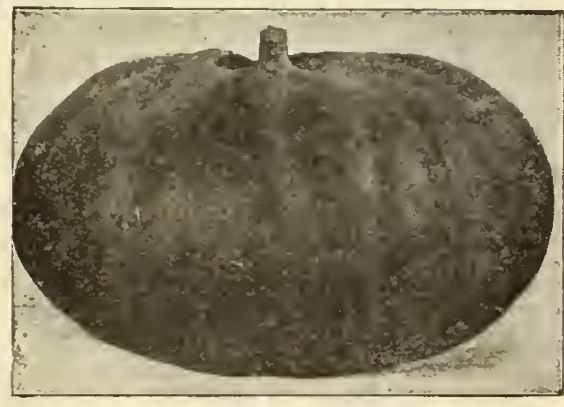

Large Sweet Cheese
Tivingston's Pumpkin MixtureLivingstom furnishes Pumpkins for One sowing fispecially offered to the season. Especially offered to those who wish to grow a grand colLarge Pkt., 10c.: oz.. 20c.; 1/4 lb., $50 \mathrm{c}$

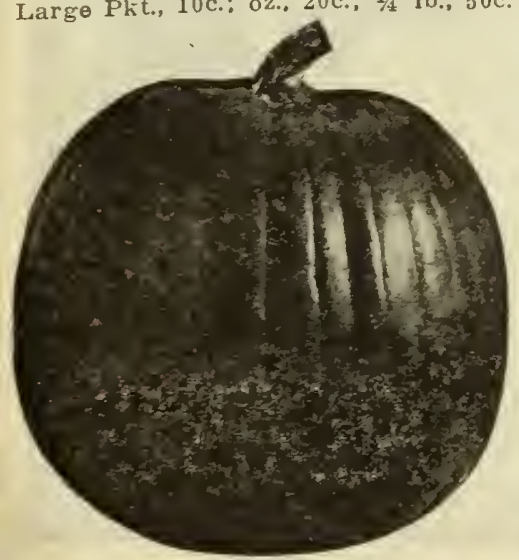

Small Sweet or Sugar

\section{Large Sweet Cheese}

Best for canning. Has heavy, thick, sweet meat; large, round, flattened variety with creamy-buff skin. An excellent keeper, and very productive; good quality. Pkt., 5c.; oz., 10c.; $1 / 4$ 1b., $25 \mathrm{c}$.; $1 \mathrm{~b} ., 75 \mathrm{c}$.

Genuine Mammoth, or True Potiron-(King of the Mammoths)-Of immense size, with depressed ends, slightly ribbed, of ten 3 feet in diameter and sometimes weighs over 200 lbs.: skin salmon color: flesh bright yellow; fair quality; great exhibition sort. Pkt., 5c.; oz., $15 \mathrm{c}$.; $1 / 4 \mathrm{~b}$., 35c.; lb., $\$ 1.25$

Winter Iuxury-The fruits are of medium size, nearly round and very thick meat; flesh is light yellow: excellent for pies. Pkt., 5c.; oz., 15c.; 1/4 1b., 35c.: 1b., $\$ 1.25$.

Tennessee Sweet Potato-Bell shape: medium size, thick flesh; skin creamy white, fine grained, sweet, delicious. Very fine for pies. Pkt., 5c.; oz., 10c.; lb., 30c.; 1b., \$1.10.

\section{Ruibarbo Rhuburb, or Pie Plant Rhebarber}

Requires a deeply cultivated and thoroughly manured soll. Sow the seed early in the Spring, in rows 1 foot apart: the second year aftel planting, plants can be removed in Autumn to the permanent place in the garden allotted to victoria-In general use for market and home garden. Plit., 5c.; oz, $10 \mathrm{c}$. $1 / 4$ 1b., $25 \mathrm{c}$.; 1b., $85 \mathrm{c}$.

Charles Haukins, Philippine Islands, writes, January 21, 1918: "Have the honor to report the seeds that you sent to me on Nov, 4, 1917, have all germinated well.

Martin W. Schnette, Cuyahoga Co., O., writes: "I received all seeds ordered and find everything just as ordered and have radishes and lettuce coming up. I thank you for your prompt service," 


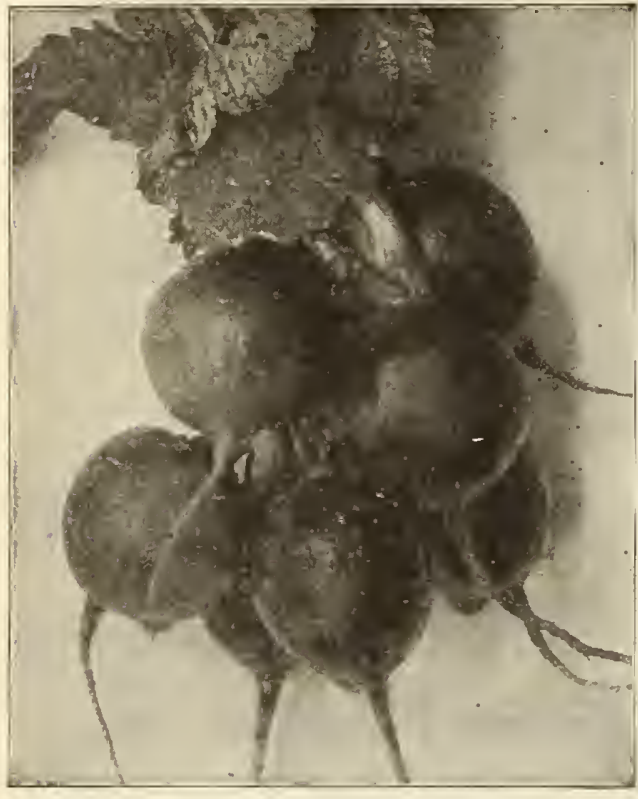

Scarlet Globe Radishes

\section{Rabanitos Radishes radieschen}

All varieties thrive best in light, sandy loam. For early use, sow in the hotbed in February, giving plenty of ventilation, or outside in the garden, in drills, as soon as the soil is warm and dry, covering the seed about half an inch deep. Sow every two weeks from March until September for a succession of crisp Radishes for continued use. Radishes must grow rapidly to be crisp, mild flavored and tender. We drill; 8 to 10 ponnds for an acre.

\section{Rosy Gem}

One of the earliest, perfectly globular: rich brilliant scarlet at top, blending into pure white at bottom, tender and crisp; adapted to greenhouse culture; desirable for market or home garden. Pkt., 5c.; oz., $15 \mathrm{c}$; $1 / 4$ lb., $50 \mathrm{c}$.; , 1b., $\$ 1.75$.

\section{Non Plus Ultra (or Fireball)}

The earliest forcing Radish in cultivation. A pretty little round Radish; deen, rich scarlet in color: tops rery small: crisp, tender, white flesh; a little earlier than Scarlet Globe, but not so large. Pkt., $5 \mathrm{c} . ;$ oz., 15c.; $1 / 4$ lb., 50c.; 1b., $\$ 1.75$.

\section{Early Scarlet Turnip}

Quite early, small, round Radish; skin, rich scarlet. A great favorite with market gardeners and especially so for kitchen gardens. Pkt., 5c.: oz., 15 c.: $1 / 4$ 1b., 50c.: 1b.. $\$ 1.65$.

\section{Crimson Giant}

A variety combining earliness and great size. It grows much larger than other extra-early varieties, but does not become pithy, even when fully twice as large in diameter and a week older; beautiful crimsoncarmine; turnip-shaped; flesh firm, crisp and tender. We recommend it for outdoor garden planting as well as for greenhouse forcing. Pkt., 5c.; oz., 15c.: $1 / 1$ 1b., 35c.; 1b., $\$ 1.26$.

\section{Scarlet Globe}

This splendid globe Radish is the very finest early strain of the round. bright red Radishes. Nothing can surpass its table excellence or its beauty. The skin is a bright scarlet; flesh pure white, crisp, tender and of delicious quality. Fine for market gardeners as first-early forcing Radish. Pkt., 5c.; oz,. 20c.; $1 / 4$ lb., 65c.; 1b., $\$ 2.00$.

\section{Model White Box}

Short top, of rapid growth; perfect turnip shape; extra fine quality, remaining solid and juicy for a long time; is especially suitable for growing under glass in frames. Pkt., 5c.; oz., 15c.; $1 / 4$ lb., $35 \mathrm{c}$; ; 1b., $\$ 1.10$.

\section{Early Snowball}

One of the quickest growing besides being one of the prettiest round varieties in the whole list; white as snow, smooth as glass, very crisp and extremely tender. Pkt., 5c.; oz, 15c.; 1/4 lb., 50c.;

\section{Early Golden Yellow Oval}

A very fine olive-shaped variety. Flesh is white and tender. Fine for forcing or out-door culture.

\section{Brightest Long Scarlet}

(Cardinal White-Tipped) - Resembles Early Long Scarlet ShortTop in shape and size. but of a lighter shade of scarlet: extraearly; white tipped; a rapid seller. $\$ 1.00$

\section{Early Long Scarlet Short-Top}

Admirable for forcing; the leading outdoor quick-growing variety both for private and market gardens: the average length is 6 to 8 inches: grows about half out of the ground straight uniform: tops small: bright scarlet in color, brittle and crisp. Pkt., 5c.; oz., $15 \mathrm{c}$.; $1 / 4$ lb., $35 \mathrm{c}$.; ib., $\$ 1.25$.

\section{Half-Long Deep Scarlet}

Color deep, rich red. Shape half-long, tapering. Flesh pure white, crisp, tender, brittle, not becoming pithy for a long time. Pkt.. 5c.; oz., 15c.; 1/4 1h., 50r.; lh., $\$ 1.65$.

\section{Scarlet Turnip White Tip}

Handsome, bright scarlet, with white tip. Similar to the Sparkler. Pkt., 5c.; oz., 15c.; 1/4 lb., 35c.; lb., $\$ 1.25$.

\section{French Breakfast}

of quick growth, very mild and tender; of an oval form, scarlet tipped with white. One of the best real early sorts for home garden. Popular with many growers. Pkt.,

\section{Improved Chartier}

A distinct and exceedingly attractive sort; a clear rose colored long Radish, shading, into pure waxy white at the tips, attains large size. Perhaps one of the best Farly Summer Radishes for the open Summer Radishes for the open for use or market early; keeps crisp for use or market early; keeps crisp a long time. Should not be sown $5 \mathrm{c}$; oz., 10c.; $1 / 4$ lb., 30c.; 1b., $\$ 1.00$.

\section{Saxa}

This variety is of a beautiful scarlet color, round as a marble and having a very small top and tap root. It comes so quick that it has been placed on the dining table in three weeks from the time of sowing seed. The flesh of Saxa is very crisp, brittle and juicy, and remains in fit condition for the table for a long time. It is adapted to sowing in open ground as soon as it can be worked and it is a fine sort for greenhouse crops, for which it was especially developed. Pkt., 10c.; 1/2 oz., 15c.; oz., $25 \mathrm{c}$; ; 1/4 lb., 70c.; $1 \mathrm{~b}$., Wood's Early Frame

earlier than the Early Long Scarlet Shortfirst sowing outside, as it is quite hardy.

\section{Cooper's Sparkler}

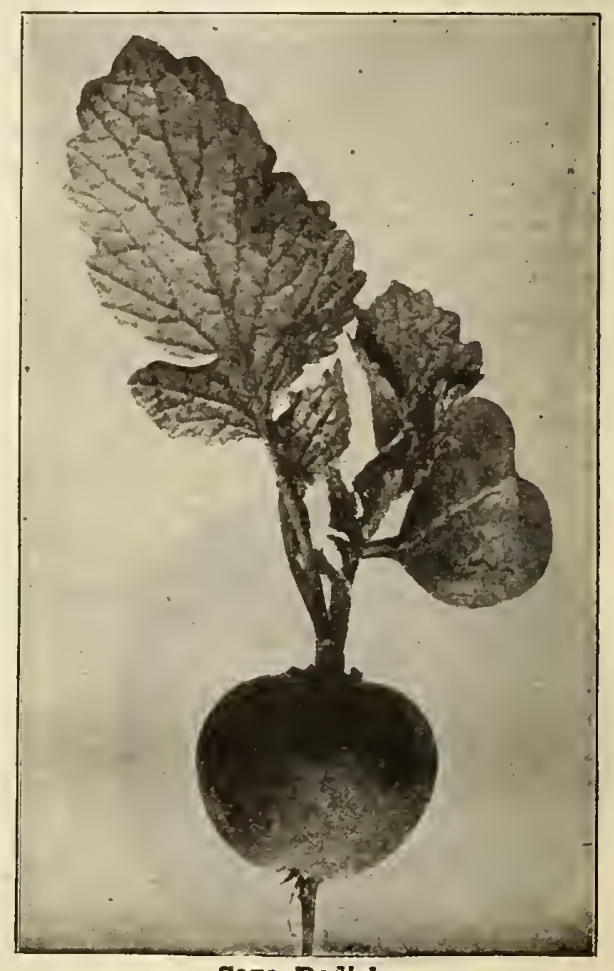

Saxa, Badish 


\section{Squashes spelse-zarbisse}

Plant after weather has become firmly settled and the ground is warm and dry in hills 5 to 6 feet apart for bush varieties, and 6 to 8 feet apart for running varieties. Hills should be thoroughly manured. Slightly elevate the hills and place 7 to 8 seeds in each, finally leaving but three plants. Press the seeds down firmly before covering, and plants. Press inches. One ounce of the Bush varieties for 40 hills, or of inches. One onnce of the Bush varieties for 40 hills, or of of the Bush sorts, or 4 to 5 pounds of the large-seeded winter kinds are needed for one acre.

\section{Livingston's Pie}

Rich Sweet Flavor. Makes Good Pies Without Eggs. The color of the skin is similar to that of the Golden Pusset Apple Flesh yellow and very thick. Quite early, surprisingly productive and a rapid and hardy grower. The very finest for pies, making good ones even when eggs are not used. Size, 8 to 10 inches in diameter. Large Pkt., $10 \mathrm{c}$; 0z., 15c.; $1 / 4$ ib., 50c.; 1b., $\$ 1.75$.

\section{Giant Golden Summer Crookneck}

The largest and best of all Summer Crookneck Squashes. of a dwarf, bushy habit and very productive; bears early and all Summer; true Crookneck type; rich golden yellow color; thickly warted. Its cooking qualities are unexcelled. One of the best varieties for the market or table use. Pkt., 5c.; oz., 15c.; 1/4 1b., 50c.; 1b., \$1.75.

\section{Mammoth Yellow Bush Scallop (Golden Custard)}

Decidedly the best strain of Yellow Scalloped Summer Squash Double the size of the old sort retaining all its good points. Pkt., 5c.; 0z., 15c.; 1/4 lb., 50c.; 1b., $\$ 1.75$.

\section{Fordhook}

Convenient size for family use. Flesh dry and sweet, and seems incapable of rotting. The thin, hard stem and roots furnish absolutely no food for the squash borer. Maturing early, it is a sure cropper and immensely proMay. be used at any stage of growth. Pkt., 5c.; oz., 15c.; $1 / 4$ ib., $50 \mathrm{c}$.; lb., $\$ 1.75$.

\section{Boston Marrow}

Oval form, thin slin. Color a rich orange: of good size, excellent flavor and keeps well. Pkt., 5c.; 0z., 15c.; 1/4 lb. 35 c.; lb., $\$ 1.15$.

\section{Essex Hybrid}

Hard shell; solid, thick-fleshed; fine grained, rich flavored; prolific, and of the best quality. Flesh rich orange color. Turban shape. Pkt., 5c.; oz., 15c.; 1/4 1b., $35 \mathrm{c}$.; 1b., $\$ 1.25$.

\section{Hubbard}

The Standard Winter Squash-It is of good size, often weighing 9 to 15 pounds. Color bluish green. Flesh fine grained, sweet and of excellent flavor. Has a very hard shell and will keep until Spring. Plkt., 5c.; oz., 20c.; 1/4 Ib., $65 \mathrm{c}$. ; $1 \mathrm{~b} ., \$ 2.00$.

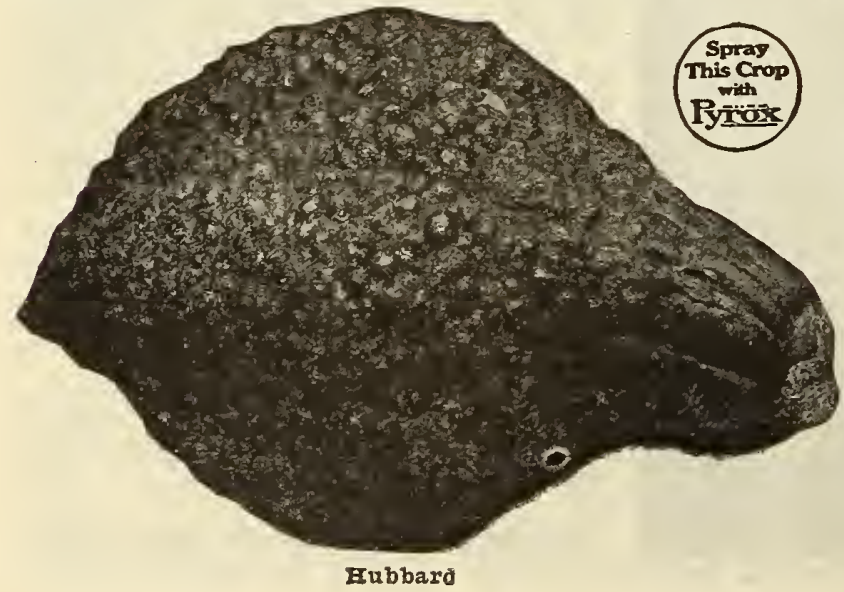

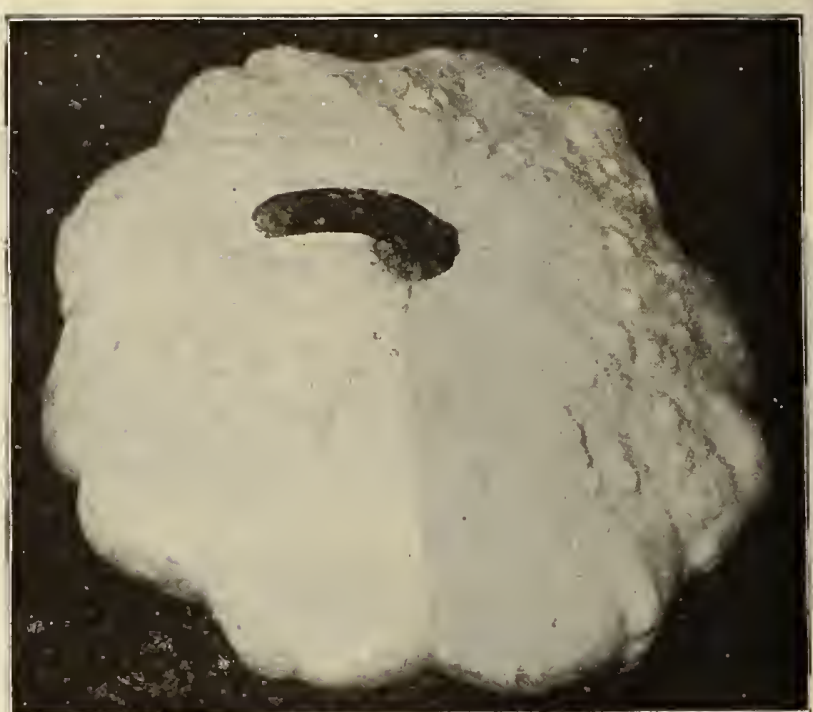

Early White Bush, or Patty Pan

\section{Early White Bush, or Patty Pan}

Bears fruits ready for use very early in the Summer. of true bush and very productive, should be eaten when young and tender. Pkt., 5c.; oz., 10c.; 1/4 1b., 30c.; 1b., \$1.00.

\section{Mammoth White Bush Scallop}

Excellent large strain. Nearly as early as the common sort: creamy white; splendid for market or home garden: good shipper. Pkt., 5c.; oz., 15c.; 1/4 1b., 35c.; 1b., \$1.15.

\section{Livingston's Improved Cushaw}

Very beautiful in appearance, being a distinct mottled green and white striped. Flesh yellow, solid fine grained, very sweet, and excellent for pies; also good for baking. They are hardy, and bugs seldom eat them, especially when other varieties are near. Can be grown among corn, same as pumpkins, and yield as good crop, but the better way is to grow them separately on good rich soil in hills 10 to 15 feet a part each way. Pkt., 5c.; oz., 20c.; 1/4 1b., $65 \mathrm{c}$; ; lb., $\$ 2.00$.

\section{Chicago Warted Hubbard}

Large size, dark green color, distinguished by a dense covering of knots (warts), a sure indication of splendid quality; thick flesh. Pkt., 5c.; 0z., 25c.; 1/4 1b., 70c.; 1b., $\$ 2.25$.

\section{Golden Hubbard}

Color bright, rich, orange-red; showy and attractive. Shell hard and warty. Flesh deep golden yellow, fine grained and of splendid flavor; cooks dry. Pkt., 5c.; oz., 25 c.; $1 / 4$ 1b., 65 c.; lb., $\$ 2.00$.

\section{Gregory's Delicious}

The result of years of selection and crossing, the Hubbard having been prominently used in its make-up. Greer when matured. Flesh thick, dark orange in color; dry, sweet and of rich flavor. Is best as Fall and Winter variety, improving with age. Pkt., 5c.; oz., 15c.; 1/4 lb., 50 c.; 1 b., $\$ 1.75$.

\section{Mammoth Chili}

Targest of all Squashes-Oblong, jiroductive: profitable for stock. Pkt., 5c.; Oz., 15c.; 1/4 lb., $35 \mathrm{c}$; ; lb., $\$ 1.25$.

\section{Livingston's Squash Mixture}

One sowing will produce Squashes for the season. This mixture contains a great variety of Summer and Winter Sorts, just suited for growing for exhibition or table use. Large Pkt., 10c.; oz., 15c.; $1 / 4$ lb., $35 \mathrm{c}$. 


\section{salli Salsify or Oyster Plant kaferwurzel}

When properly cooked it is a good substitute for oyster flavor and is very nutritions. A most palatable regetable; the cultivation is precisely the same as directed for Parsnips and Carrots. Salsify will keep finely through the Winter, in the ground where sown, in exactly the same manner as Parsnips. The roots are perfectly hardy; in fact they are best after the frost has touched them.

When cooking, boil the roots in small piece of codfish, which should be discarded when the salsify is done, boiled with them strengthens the oyster flavor; when cold, mash and fry as patties or fritters. This vegetable is also good stewed, plain boiled, and also as a salad, sliced raw in vinegar with pepper and salt. Sow early in drills 18 inches apart and cover firmly one inch deep; thin to three inches apart in the drills. One onnce of seed will sow fifty feet of drill; eight pounds is suffeient to plant sn acre.

\section{Mammoth Sandwich Island}

This splendid variety will average nearly twice the size of the White French Salsify. Grows very uniform. Mild and delicious in flavor. A popular sort with all growers. (See illustration.) Pkt., 5c.; oz., 25c.; $1 / 4$ 1b., T0c.; 1b., $\$ 2.50$.

\section{Espinaca Spinach spinat}

Spinach will succeed finely in any ordinary soil, and its cultivation is a very simple miatter. It is grown both as a spring and Summer crop. To winter over for Spring use, plant the seed in August or September, in drills 12 to 14 inches apart. At approach of cold weather, cover lightly with straw or any handy litter. Uncover the plants when they begin to make a new grow th in the Spring. For Summer use sow in Spring. Thin to 3 or 4 inches. One ounce of seed for 50 feet of drill; 12 to 15 pounds for an acre.

\section{Bloomsdale Savoy}

This is a very early variety and one of the best to plant in the Fall for Spring use. The plant is of upright growth, with thick, glossy, dark green leaves, which are crumpled or blistered like those of Savoy Cabbage. It is quite hardy but will run to seed quickly as soon as warm weather comes. Suitable for home use and is used also by the Southern Trucker. Pkt., 5c.; oz., 10c.; 1/4 lb., 20c.; 1b., 65 c.

New Zealand-A distinct type of Spinach. The plants grow in branching form with thick, succulent leaves. The leaves and stems can be gathered at any time after they are well grown and the plants will start out into new growth. Thrives juring hot weather and in any soil. Plkt, $5 \mathrm{c}$. $0 \mathrm{z}, 10 \mathrm{c}$. $1 / 1 / 2$ lb., 30c.; 1b., $\$ 1.00$.

Victoria-An excellent sort, whether grown for home use or market. It may be sown with equally good results either in the Spring or during late Summer and Fall. The plants are fit for use early and remain in good marketable condition much longer than most other kinds. The leaves are very thick and juicy and, when prepared properly, develop a delightfully distinct, mild flavor. Pkt., 5c.; oz., 10c.; 1/4 1b., $25 \mathrm{c}$.; $1 \mathrm{~b}$., $75 \mathrm{c}$.

Prickly Seeded Winter-A fine variety with triangular, oblong or arrow-shaped leaves. Hardiest of all, therefore best for Fall sowing where Winters are severe. Pkt., 5c.; Oz., 10c.; 1/4 1b., 20c.; lb., $70 \mathrm{c}$.

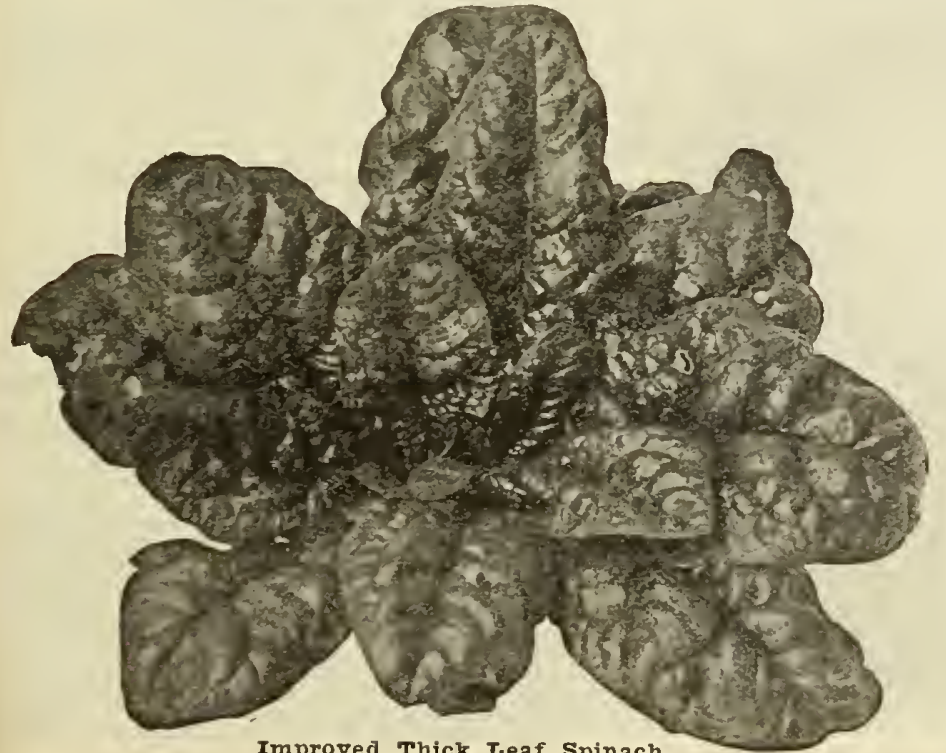

Improved Thick Ieaf (Viroflay)-The market gardener's favorite for Fall or Spring sowing. A great favorite in all parts of the country as it furnishes an abundance of heavy, broad, dark green leaves of finest quality and appearance. The leaves are attractively curled, and on account of their firmness and substance they remain in prime, salable condition for a long time. Also excellent for home use. Pkt., 5c.; oz., 10c.; $1 / 2$ lb., 20c.; 1b., 70c.

"Iong Season"-Of flat spreading, but compact growth, this sort is especially noticeable for its short-stemmed, dark green leaves, which are heavily crumpled and savoyed. For marketing during the warm summer months, it is unsurpassed. Stands longer before going to seed $10 \mathrm{c}$; $1 / 4$ 1b., $25 \mathrm{c}$; $1 \mathrm{~b}$., $75 \mathrm{c}$.

T. O. Hommert, Queens Co., N. Y., writes, Dec. 2, 1918: "Received your catalog and sample seeds this spring. Wish to state that the seeds upheld your trademarks "True Blue Seeds" for the results were as advertised. I am sorry to say that I had already placed my order for seeds when your catalog arrived, but have used same to make up my order for this coming Spring, check up the prices and place my first order for "True Blue Seeds" as soon as possible."

Mr. Geo. Gregory, Jackson Co., Mich, writes as follows: "I enclose order for Seed. I can say I have been very much pleased with your seeds in the past. They have been true to name and of Improved Thick Leaf Spinach high vitality. Will send an order later on." 


\section{zuben Turnips жrabos}

First-early' varieties of Turnips should be planted just as early in the Spring as the ground is dry and warm. Sow them in drills, beds, or later broadcast, or among corn. The Ruta-Baga varieties, and also the early sorts, will do better if planted in drills; make the drills at least 18 inches apart, and thin out the plants when well up to six inches apart. Cultivate often and thoroughly. We call especial attention to the fact that the Ruta-Baga varieties should be planted as soon as possible after the middle of June, as they need a longer season than the earlier sorts of Turnips. One ounce of seed sows 100 feet of drill; one pound an acre.

\section{Extra-Early Purple-Top Milan}

The earliest of the flat Turnips, with a beautiful purple top. They are mild and sweet. Pkt., 5c.; 1/2 oz., 20c.; oz., $30 \mathrm{c}$; $1 / 4$ lb., $85 \mathrm{c}$.; 1b., $\$ 3.00$.

\section{Extra-Early White Milan}

Similar to Purple-Top Milan, excent it has pure white skin and flesh. Pkt., 5c.; $1 / 2$ oz., $20 \mathrm{c}$; oz., $30 \mathrm{c}$; $1 / 4$ lb., $85 \mathrm{c}$. lb., $\$ 3.00$.

\section{Early Snowball}

Medium-sized round Turnip, pure white, very fine flavor. Pkt., 5c.; 1/2 oz., 10c.; oz., 15c.; 1/4 1b., 35c.; 1b., $\$ 1.25$.

\section{Early White Egg}

An early variety. Flesh white, firm, fine grained, mild and sweet. A fine Turnip for Winter use. Pkt., 5c.; 1/2 oz., 10c.; oz., 15c.; $1 / 4$ lb., 35 c.; lb., $\$ 1.25$.

\section{Early Flat Dutch, or White Strap-Leaved}

A standard flat variety; good size; pure white; small top, few leaves; good early or late. Plst., 5c.; oz., 10c.; $1 / 4$ 1b., 30c.; lb., $\$ 1.00$.

\section{Long White, or Cow Horn}

Long; grows rapidly, partly above ground; slightly rooked; productive: white, fine grained, very sweet. Used for plowing under to improve the soil. Pkt., 5c; $1 / 2$ oz. $10 \mathrm{c}$.; oz., $15 \mathrm{c}$.; $1 / 4$ lb., $50 \mathrm{c.;}$ ib., $\$ 1.75$.

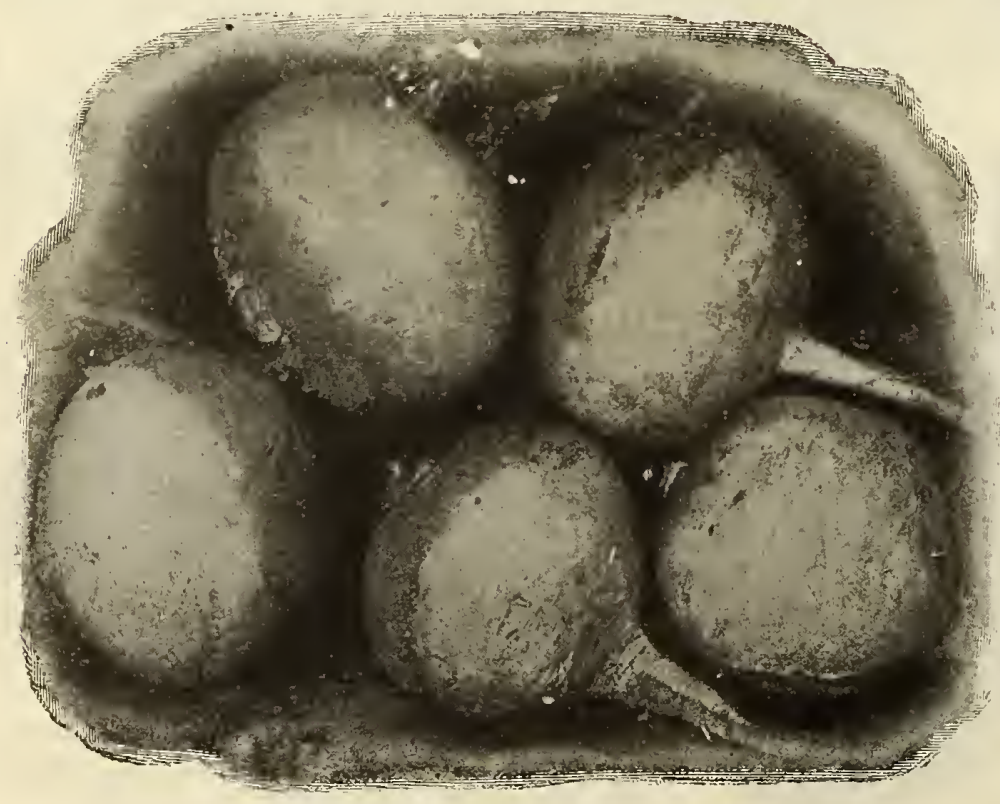

Parple-Top White Globe Turnips

\section{Purple-Top Strap Leaf}

A popular variety for family or market use; white, purple above ground; flesh fine-grained; good for Winter use or late planting. Pkt., 5c.; oz., 10c.; $1 / 4$ lb., 30c.; lb., $\$ 1.00$.

\section{Seven Top}

Cultivated extensively for the tops, which are used as greens. Pkt., 5 c.; 1/2 oz., 10c.; oz., 15c.; 1/4 1b., 35c.; 1b., $\$ 1.25$.

\section{Purple-Top White Globe}

A variety of decided merit. Globular shape and of superior quality, either for the table or stock; heavy yielder. Pkt., 5c.; oz., 10c.; $1 / 4$ lb., 30c.; 1b., $\$ 1.00$.

\section{Large White Globe (Pomeranean)}

Similar to Purple Top White Globe, except in color, which is pure white; firm, sweet flesh. Pkt., 5c.; $1 / 2$ oz. $10 c_{\text {. }}$ oz., 15c.; 1/4 1b., 50c.; lb., $\$ 1.75$.

\section{Yellow Globe, or Amber}

Sweet; large; fine for table or stock. Pkt., 5c.; $1 / 2$ oz., $10 \mathrm{c}$.; Oz., $15 \mathrm{c}$; ; $1 / 4$ lb., $35 \mathrm{c}$.; 1b., $\$ 1.25$.

\section{Golden Ball, or Orange Jelly}

Rapid grower; globe shaped; is bright yellow. The best of the yellow sorts for table use Keeps well. Pkt. $5 \mathrm{c}$; $1 / 2$ oz., 10c.; oz., 15c.; $1 / 4$ lb., $35 \mathrm{c}$; ; ib., $\$ 1.25$.

\section{Ruta-Baga}

(Swedish or Russian Turnips)

Ruta-Bagas are more especially adapted to sections north of Ohic. They require a longer season for maturing, hence should be sown earlier than Turnips, or about June 15.

\section{Improved American (Purple Top)}

Very hardy and productive; flesh yellow, sweet and solid; good for stock or table use. Pkt., 5c.; $1 / 2$ oz., 10c.; oz., 15c.; 1/4 1b., 50 c.; 1b., $\$ 1.75$.

\section{Large White Russian, or Swede}

Grows very large; excellent for table or stock; flesh is firm, white and solid; the best keeper of any white variety. Pkt., 5c. 1/2 oz., 10c.; oz., 15c.; 1/4 lb., 50c.; lb. $\$ 1.75$.

Mr. T. W. Jennet, Baldwin County, Ala. "I could get my seeds all of them at Mobile, but they do not come true to name. I found last year that many varieties I got of you came much better. I gave your Catalogue to one of my neighbors, a gardener, and advised him to send to you if he wanted good seed that would come up." 


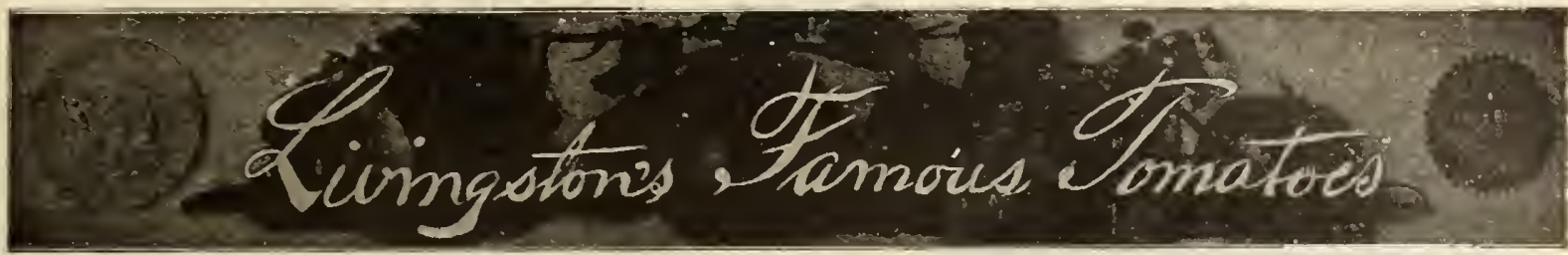

New Varieties of Merit and the Growing of Large Quantities of Seed Our Specialty

\section{We Grow More High Grade Tomato Seed than any Other Seed House in the World}

Tomatoes occupy continually the center of the stage in our establishment. It is only natural that it should be so. Few seedsmen in the world can make as positive a statement in connection with a crop as we make it

We make it a point to know and study all sorts. Thls is one of the reasons why we can speak authoritatively about the merits of the various sorts introduced. The descriptions given in this catalog may be relied upon. They tell the truth as we learn it from our annual extensive trials. Neither larger nor more thorough trials of tomatoes are made any" where than those on our "True Blue" Seed Farms. Thy enable us to "keep posted" for the benefit of our customers, ence. We give here a complete list of our introductions and no doubt you'll find some old, familiar sorts that have "made good" with you among these varieties.

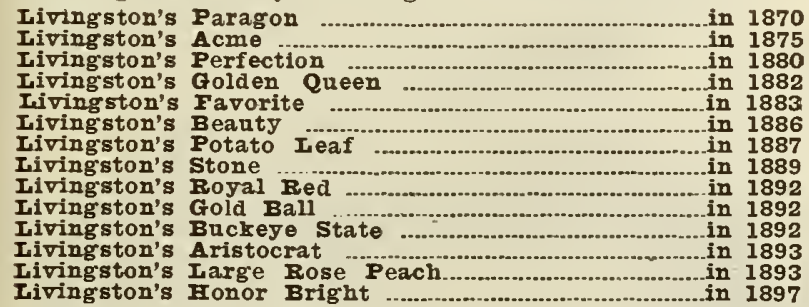

Iivingston's Dwarf Yellow Prince in 1898 Livingston's Aristobright

Iiving'ston's Royal Colors

Livingston's Dandy Dwarf

Iivingston's Multicolor

Iivingston's Frincess

Iiving'ston's Granduz

Iivingston's Dwarf Stone

Livingston's Purple Dwarf

Livingston's Globe

Living'ston's Hummer

Livingston's Coreless .........

in 1900

1901

in 1901

in 1901

in 1901

in 1901

in 1902

in 1903

Tomato Culture For very early fruit, the seed

Tomatoes grow splendidy trained to stakes or trellises, and the fruit is much improved, not only in appearance, among gardeners who grow the early market, and at private places throughout the country; especially is this desirable where neatness and at the same time economy of space in the home garden is desired. The usual method the plant up with plant to a stake 5 to 7 feet high, tying pruning quite freely as the vine advances in growth, By this method plants may be set much this method plants may be set much closer than in the attractive appearance generally, grow the clusters of the fruit in paper sacks, as is commonly practiced by grape growers. These paper sacks or bags should be put on about 2000 plants will be produced from one ounce of seed is a safe estimate.

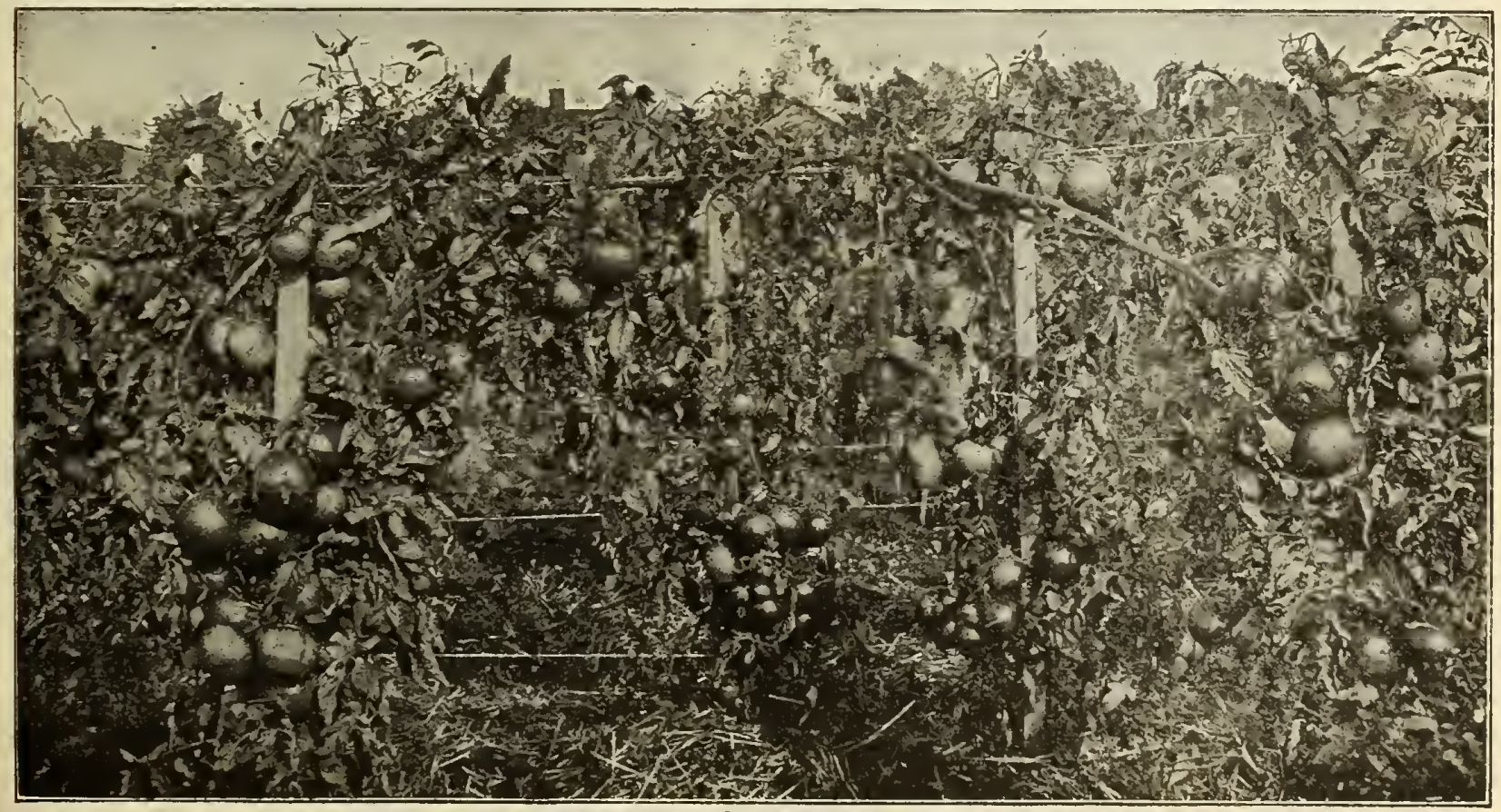

A Good Method of Staring Tomatoes 


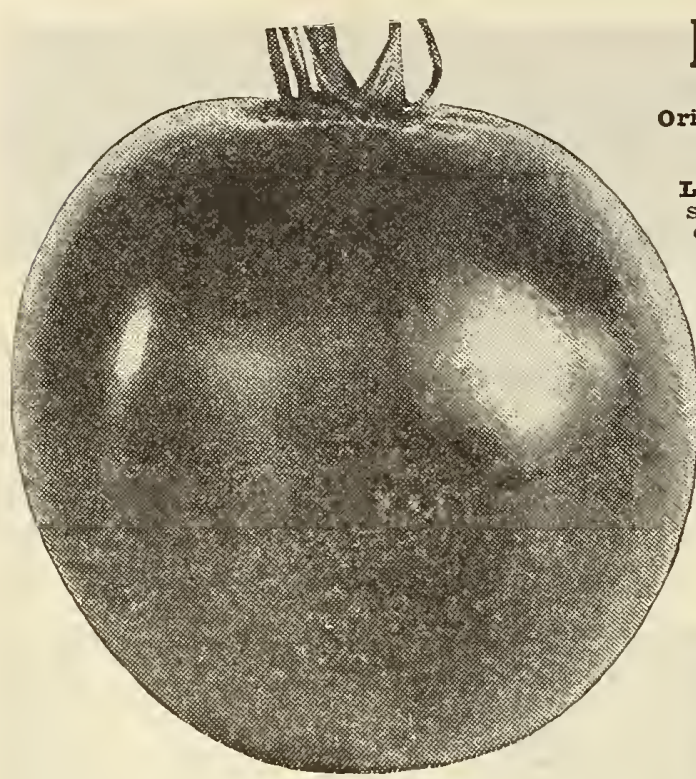

\section{Livingston's Globe Tomato}

Originated With Us and Introduced in 1905. The Finest Farly Purple Tomato in Existence. Very Distinct in Shape, Firm Fleshed, of Delicate Flavor. Almost Blight Proof.

Iivingston's Globe is an extra good all-round sort, of a distinct globe shape, with quite a large percentage of elongated fruits, on account of its shape, one that permits of a great number of slices to be made from each fruit. We class it with the first earlies, both in greenhouses as well as in the field. The fruits are of large size, and a good marketable size is retained throughont the season. It is always smooth, of firm flesh and few seeds; ripens evenly; color, a fine glossy rose, tinged with purple, and without the slightest tinge of yellow at any stage of ripening. It is an exceedingly productive variety. In quality there is nothing more to be desired, being mild, pleasant and of delicious flavor. There is no better variety for green house growing or for early growing on stakes or trellises. Its blight-proof qualities are remarkable. May be picked quite green, will carry to distant markets in excellent shape and ripen up uniformly. Pkts., 5c. and 10c.; 1/2 oz., 30c.; oz., 50c.; 1/4 1b., \$1.75; lb., $\$ 6.00$. Special prices in la 1 ger quantities.

M1. R. Baily Carson, of Peoria Co., Ill., writes, under date or Oct. 11th, 1918: "In my humble opinion, your Livingston's Globe is far and away the best Tomato ever produced for the home garden.

Iivingston's Globe

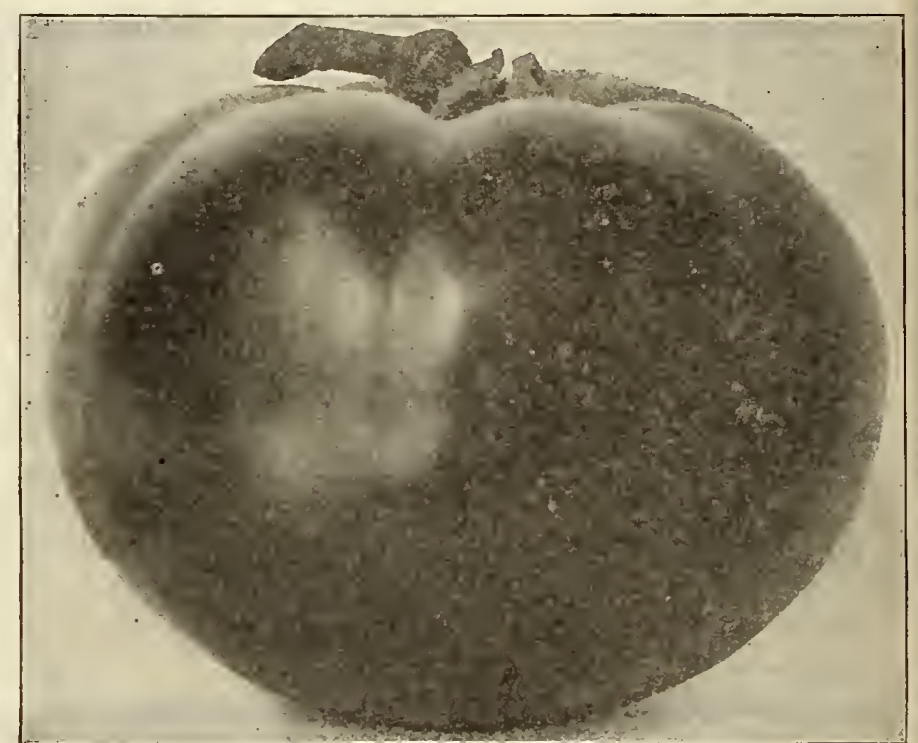

(Introduced by $U s$ in 1875.) As a shipping sort for growing in Southern States it is one of the best. This was the first perfectly smooth, large purple Tomato introduced. Todar, after all these years, it is still the leading sort with extensive growers in the South, particularly in Texas. It is a smooth, uniform, medium-sized, early, purplefruited sort, very prolific. Fruits in clusters of four or five, are of medium size and free from craclis are solid and stand long-distance shipment; quality fine Pkt., $5 \mathrm{c}$ and $10 \mathrm{c} . ; 1 / 3$ oz., $25 \mathrm{c} . ;$ oz., $40 \mathrm{c} . ; 1 / 1 \mathrm{~b}$. $\$ 1.25 ; 1$ b., $\$ 4.25$.

\section{Livingston's New Manyfold}

(Introduced in 1917.) A fine new Livingston variety. An early bright red sort, producing its fruit in large clusters. See it in colors on outside cover and fully described on page 7. Pkt., 15c.: $1 / 4 \mathrm{oz}$. $50 \mathrm{c}$; $1 / 2$ oz., $90 \mathrm{c}$; Oz., $\$ 1.60 ; 1 / 4$ 1b., $\$ 5.00 ; 1 \mathrm{~b}$., $\$ 17.00$.

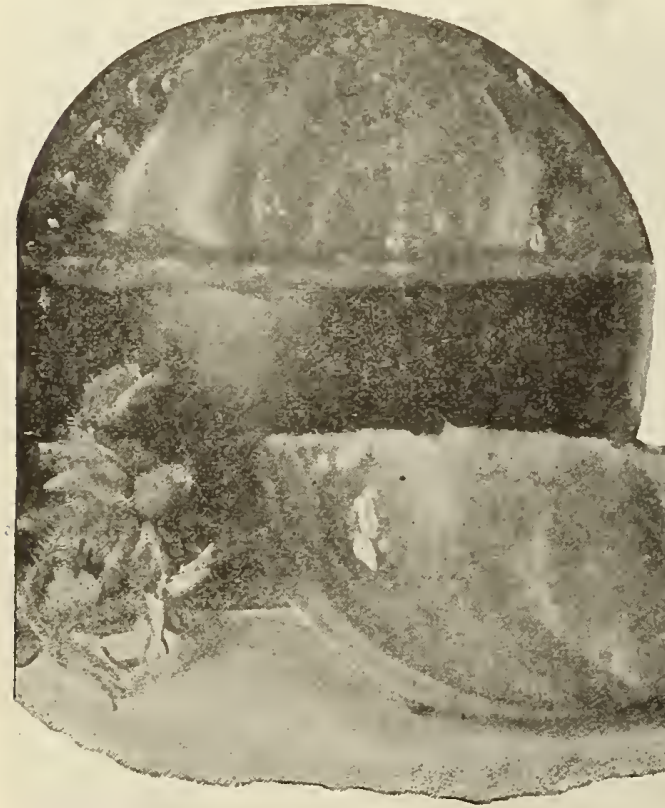

Livingston's Stone

\section{Livingston's Stone}

THE GREATEST OF AII CANNING TOMATOES The Iargest, Bright Red, Perfectly Smooth, High-Yielding, BestKeeping, Finest-Flavored Main-Crop Variety in Existence. Introduced by Us in 1889 .

Iivingston's Stone is always of good size, deep through from stem to blossom-end and very firm. Skin is bright scarlet, perfectly smooth and strong enough to stand shipping and long distance hauling to perfection. Flesh is very, solid and of finest flavor. Seed cells are small and few. Livingston's Stone is now recognized by all as the greatest canning Tomato. We alone supply enough seed to the leading Tomato growers and canners every year to produce millions of plants. Order direct from us to get seed of our growing. Pkts., $5 \mathrm{c}$. and $10 \mathrm{c}$.; $1 / 2$ oz., $30 \mathrm{c}$.; oz., $50 \mathrm{c}$.; $1 / 4 \mathrm{lb}$., $\$ 1.75 ; 1 \mathrm{~b}$., $\$ 6.00$.

\section{Livingston's Beauty}

The greatest of all Purple-Colored Fome Market Sorts. Strong Grower. Very Productive. Iarge, Smooth and Early. (Introduced by Us in 1886.) Although introduced by us so many years ago, this is still one of the most popular purplecolored Tomatoes. The plants make a strong growth, are hardy and bear plentifully. The fruit is produced in clusters of 4 to 6 , is large, of perfect shape, and retains its size until late in the season. It ripens early, has firm flesh of excellent quality, and the seed cells are very small. For home market it is excellent. May be picked quite green; will ripen up nicely, look well and keep in perfect condition for several
days. Pkts., 5c. and 10c.; 1/2 oz., 25c.; oz., 45c.; 1//4 lb., $\$ 1.50$ lb., $\$ 5.50$

All Prices Quoted in This Catalogue are Subject to Change Without Notice. 


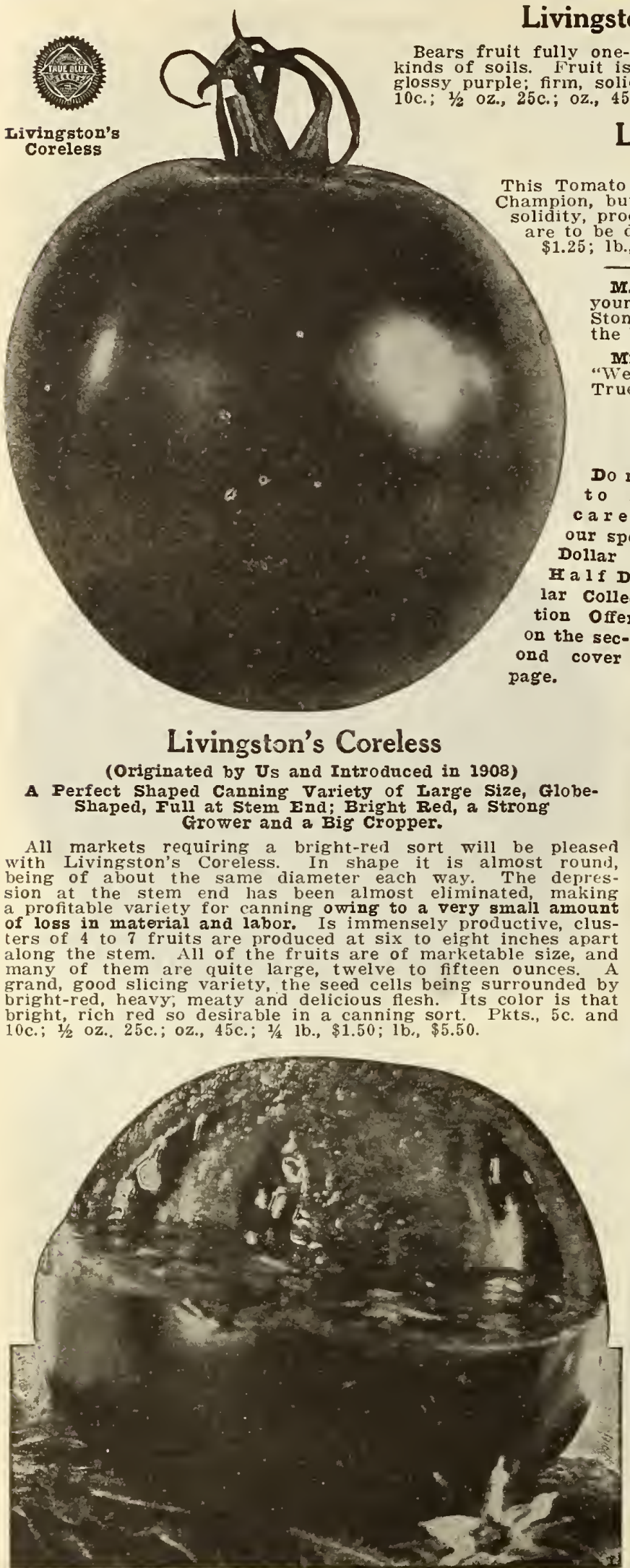

\section{Livingston's Dwarf Aristocrat}

(Introduced by $U_{s}$ in 1893.)

This Tomato in habit of growth and foliage resembles the Dwarf ampion, but the color is a beautiful rich, glossy red. The size are to be desired. Pkts., 5c. and 10c.; $1 / 2$ oz., $25 \mathrm{c}$; ; oz., $40 \mathrm{c}$.; $1 / 4 \mathrm{lb}$ $\$ 1.25 ; 1 b ., \$ 4.25$.

M. A. Hull, Iogan County, Ohio, writes: "I have used your Manyfold Tomatoes for my early Tomatoes, and your Tomato for my late ones for two years and find them Mrs, Elizabeth Becker, Trumbull County, Ohio, writes: We always are sure of a good garden when we plant your "True Blue Seeds. Your Tomato seeds are fine."

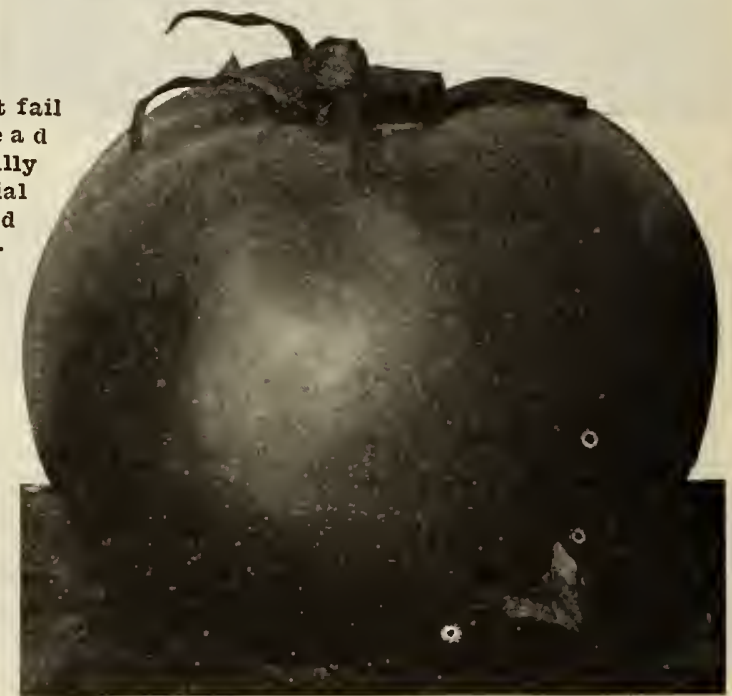

Livingston's Dwarf Stone

\section{Livingston's Dwarf Stone}

(Introduced by Us in 1902)

The advent of Dwarf Stone marked a new epoch in Dwarf Tomatoes. The fruits are larger than those of Dwarf Champion and nearly as large as those of our Standard Stone.

It is very prolific. Fruit smooth; ripens evenly, and medium early. The color is bright red. You may set the plants of Livingston's Dwarf Stone as close as $18 \times 24$ inches and still produce an abundant crop. Pkts., 5c. and 10c.; $1 / 2$ oz., $30 \mathrm{c}$; oz., $50 \mathrm{c}$; $1 / 4 \mathrm{lb}$., $\$ 1.75$.

\section{Livingston's Magnus}

One of the Finest for Growing on Stakes

(Introduced by $U_{s}$ in 1900.) This distinct variety, of the color of Livingston's Beauty, is one of the most valuable additions to the Tomato family. It is large, early, thick, heavy and solid, and one of the most handsome varieties in cultivation. Tivingston's Mast in tion of fine, lar fe fruits. while well adapted to maincrop planting, it also takes first rank for early market purposes. The form is perfect, uniform, large and attractive: quite deep through from stem to blossom end. The flesh is very firm. A robust grower, with short joints, setting its clusters closer together than most varieties, and is a very heavy cropper. It has the broad foliage which prevents sunburn in hot secthe For stakint ing in greenhouses, is fully equal to any for such purposes. Pkts., 5c. and 10c.; $1 / 2$ oz., $25 \mathrm{c}$.; 0z., $45 \mathrm{c}$.; purposes. Pkts., 5c. and 


\section{Tomatoes (Continued)}

\section{Livingston's Golden Queen}

(Introduced by $U \mathrm{~s}$ in 1882, "Queen of all the Yellows." of superior flaror, it is solid, always smooth, entirely free from ridges, large in size, ripens early. Fine for slicing. Pkts., 5c. and 10c.; $1 / 2$ oz., 25 c.; oz., 45 c.; 1/4 1b., $\$ 1.40$.

\section{Livingston's Gold Ball}

(Introdnced by 0 s in 1892.) Beautiful canary-yellow; flesh thick, fine quality; handsome color; very productive. Pkts., 5c. and 10c.; 1/2 oz., $20 \mathrm{c}$; oz., $35 \mathrm{c}$.

\section{Livingston's Dwarf Yellow Prince (Introduced by 08 in 1898)}

A very choice Dwarf-growing yellow Tomato. Very early. Flesh is solid and the flavor is desirable. Of large size and beautiful shape. When sliced with red or purple sorts it is highly ornamental. Pkts., 5c. and 10c.; $1 / 2$ oz., $25 \mathrm{c}$.; oz. is highly orname $1 / 41 \mathrm{~b}$., $\$ 1.25$.
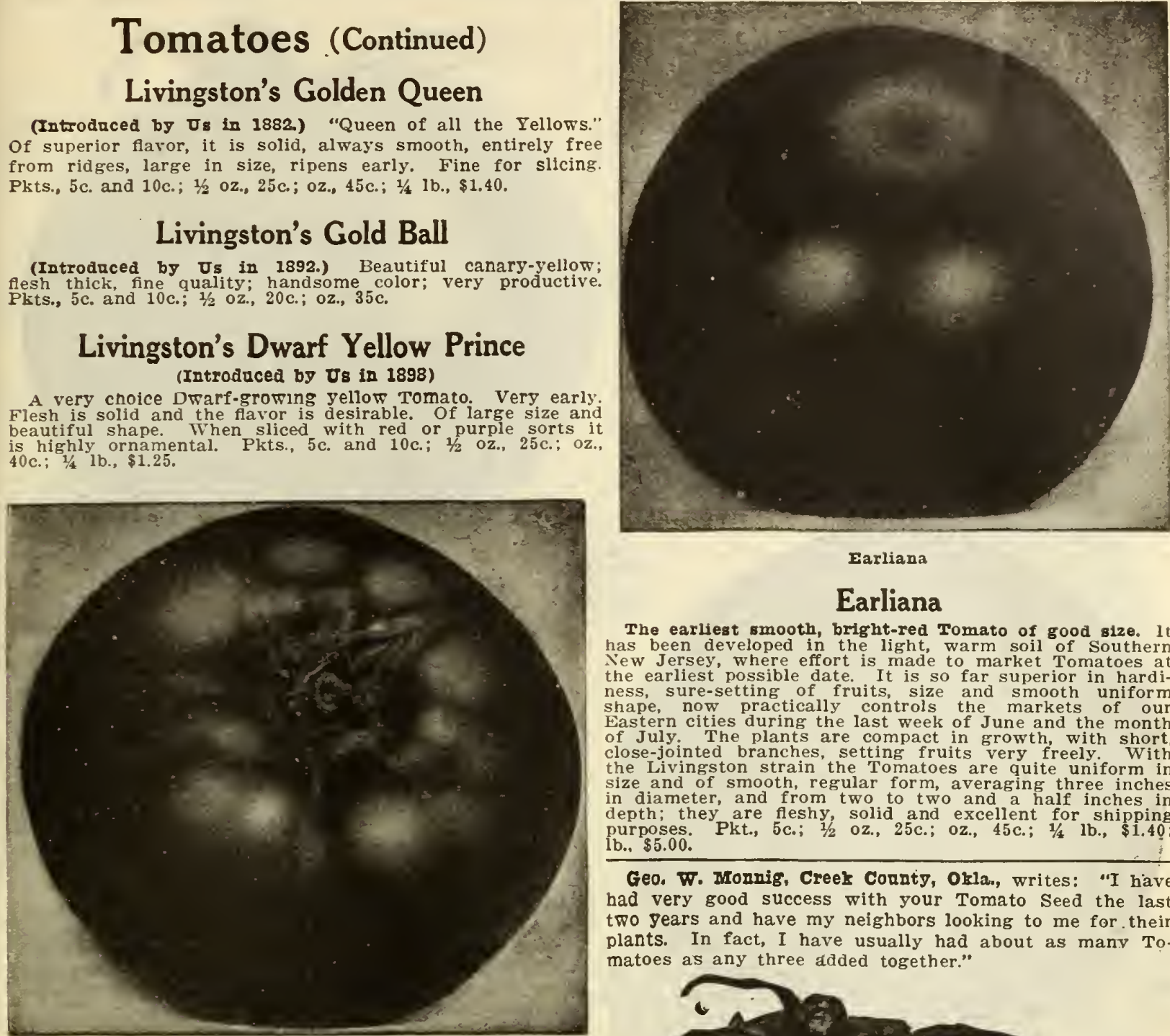

Earliana

\section{Earliana}

The earliest smooth, bright-red Tomato of good size. It has been developed in the light, warm soil of Southern New Jersey, where effort is made to market Tomatoes at the earliest possible date. It is so far superior in hardiness, sure-setting of fruits, size and smooth uniform shape, now practically controls the markets of our Eastern cities during the last week of June and the month Eastern cities during the last week of June and the month close-jointed branches, setting fruits very freely. With the Livingston strain the Tomatoes are quite uniform in size and of smooth, regular form, averaging three inches in diameter, and from two to two and a half inches in depth; they are fleshy, solid and excellent for shipping purposes. Pkt., 5c.; $1 / 2$ 0z., 25c.; 0z., 45c.; 1/4 lb., $\$ 1.40$ : lb., $\$ 5.00$.

Geo, W. Monnig, Creez County, Oklan, writes: "I have had very good success with your Tomato Seed the last two years and have my neighbors looking to me for their plants. In fact, I have usually had about as many Tomatoes as any three added together."

June Pink

\section{June Pink}

\section{A Pink Earlana}

Ripens as early as Earliana. It is an enormous bearer, clusters of six to eight large fruits being borne close to the main stem. A large percentage of the fruit being produced very early. The fruit is of medium size, uniform, smooth and attractively shaped. Excellent for shipping. In color it is a bright, pleasing pink, and in markets where a pink Tomato is desired, it is a great seller. Pkt., 5c.; 1/2 oz., 25c.; oz., 45c.; $1 / 4$ lb., $\$ 1.50$; lb., $\$ 5.50$.

\section{Chalk's Early Jewel}

A little later than Earliana-A heavy cropper, larger size, fine flavor. Brightest scarlet; ripens up to stem without green core. Flesh thick, bright scarlet, solid, sweet flavor. One of the largest cropping, medium early, varieties we grow. Comes in ahead of Livingston's Stone, almost as large. Pkt., $5 \mathrm{c}$; $1 / 2$ oz., $25 \mathrm{c}$; oz., $45 \mathrm{c}$.; $1 / 4$ lb., $\$ 1.50 ; 1 \mathrm{~b}$., $\$ 5.50$.

Jesse Prather, Payne Co., Okla., writes, Feb. 19: "Please send me your seed catalogue by return mail and oblige. I want to get your kind of Tomatoes. they are the best I ever saw."

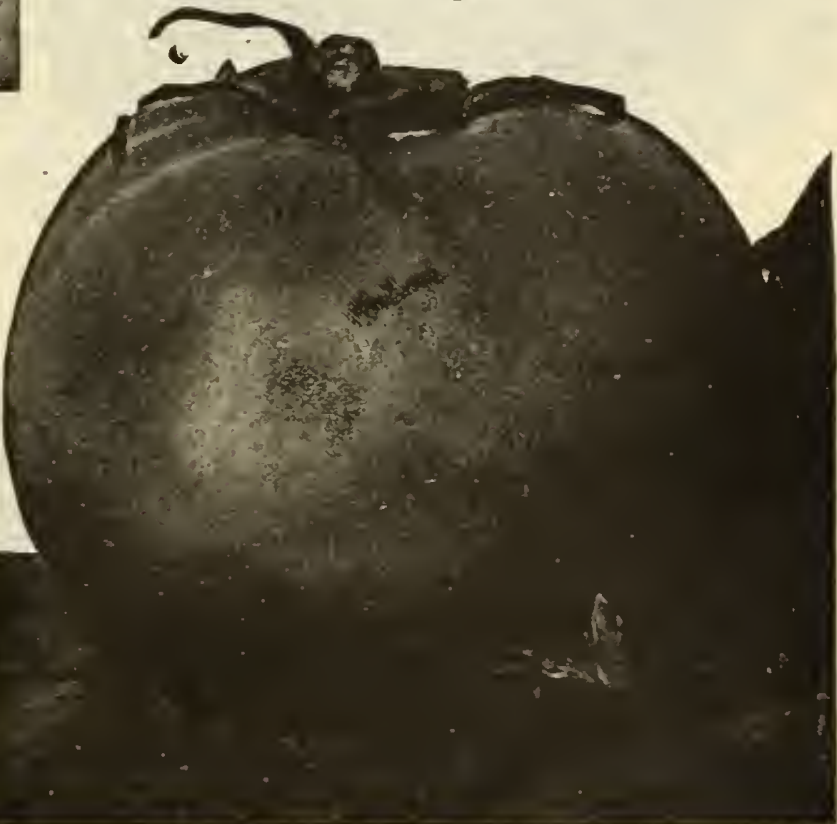




\section{Tomatoes (Continued)}

\section{Matchless Tomato}

A fine, smooth main crop Tomato, of rich cardinal red color, with solid flesh of finest quality. Grows to good size which it maintains throughout the season. Very similar to Livingston's Stone. Pkt., 5c.; $1 / 2$ oz., 30c.; oz., $50 \mathrm{c}$.; $1 / 4$ lb., $\$ 1.60$; 1b., $\$ 5.75$.

\section{Trucker's Favorite}

A purple fruited sort of excellent quality, highly esteemed in many Eastern and Southern markets. Grows to uniformly large size which is maintained until late Fall. Fruits are invariably smooth, solid and the flesh is of finest color throughout. Unexcelled for slicing or cooking. Plants are very thrifty, free from rust or blight and bear continually until killed by frost. Pkt., $5 \mathrm{c}$.; $1 / 2$ oz., $25 \mathrm{c}$.; oz., 45c.; $1 / 2$ lb., $\$ 1.45$; Ib., $\$ 5.25$.

\section{Dwarf Giant}

A new dwarf sort of good size and various other unique characteristics. It is very prolific, producing fruits in clusters around the hase of the plant. Tomatoes are smooth and of regular size and shape. Of the same color as Ponderosa-the originator calls it a "Dwarf Ponderosa." Pkt., 10c.; 1/2 oz., 25 c.; oz., $45 \mathrm{c}$.; $1 / 4$ Ib., $\$ 1.50$.

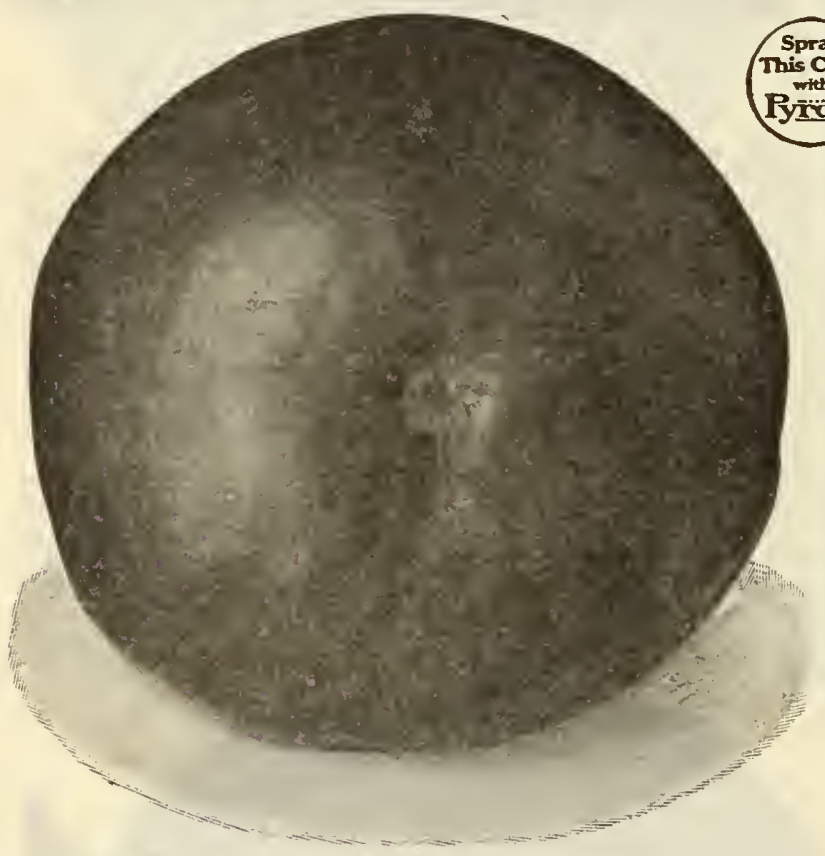

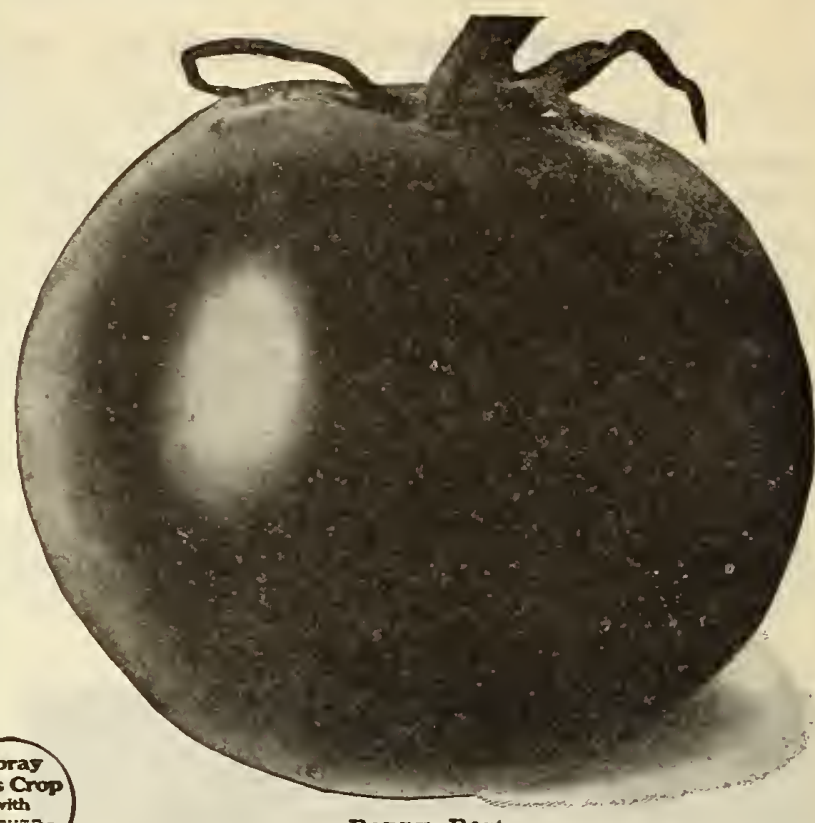

Bonny Best

\section{Bonny Best}

Best Red for Greenhouses

One of the finest bright red sorts for growing in greenlouses, and a good one to follow Earliana in the open field. It has been highly recommended by U. S. Dept. of Agriculture as well as big growers and shippers throughout the country. Bonny Best is a favorite Tomato of medium size. They are of bright scarlet color, always smooth and of remarkably uniform size and shape. A splendid sort for market and shipping. Pkt., 5c.; $1 / 2$ oz., $25 \mathrm{c}$; oz., $45 \mathrm{c}$.; $1 / 4$ 1b., $\$ 1.50 ; 1$ b., $\$ 5.50$.

I. I. Wright, Fayette Co., Ky., writes, Oct. 1, 1919, as follows: "I have fed the town on Livingston's Beauty Tomato. Such a crop I have never seen as I had, and fine in size. A hundred people have asked me the name of them. I think you will have a good trade in them from this town this Spring."

\section{All Prices Quoted in This Catalogue are Subject to Change Without Notice}

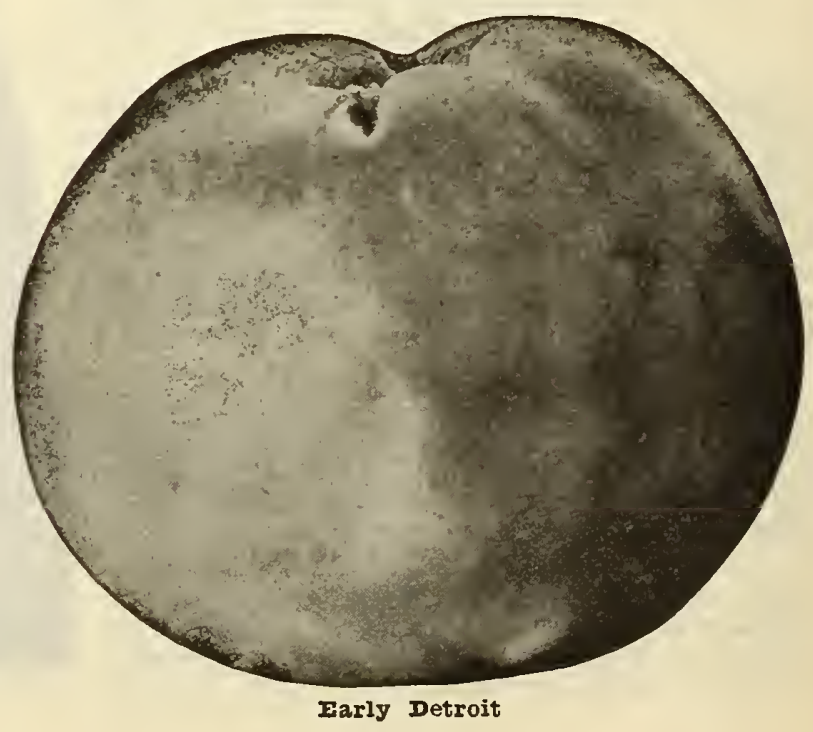




\section{Tomatoes (Continued)}

\section{Red Rock}

Red Rock is, as the name indicates, a scarlet fruited sort of large size. We class it as a late variety, but if started quite early will mature most of the crops before frost. A good general purpose sort and used as a canning variety by some. Plkt., 5c.; $1 / 2$ oz., $30 \mathrm{c}$; oz., $50 \mathrm{c}$. 1. 1b., $\$ 1.60$; lb., $\$ 5.75$.

\section{John Baer}

An extra early red fruited sort of merit. The fruits are large, nearly round, smooth and of good quality. It s a good rariety for market gardeners and for shippers Pkt., 5c.; 1/2 Oz., 30c.; oz., 50c.; 1/4 lb., \$1.60; lb., $\$ 5.75$.

\section{Odd Tomatoes}

Purple Peach-Resembles some peaches so closely in size, Pape and ceneral appealance that at a short distance away it could be taken for peach. Color purple, blended away it could be taken for peach. Color purple, blended ith orange amber: very productive. Pkt., $5 \mathrm{c}$. ; $1 / 2$ oz., $25 \mathrm{c}$. Yellow Peach-Like Purple Peach, ex

Golden Husk or Winter cherry-This delicate husk-enreloped Tomato is uncqualed for making preserves and pies. Have a strawberry flavor and are very productive. Fruit a handsome golden color, the size of large cherries.

Pht., 5c.; 1/2 Oz., 25c.

Purple Husk-Beautiful; very productive. More acid than Golden Husk. 1 to 2 inches in diameter. Pkt. $5 \mathrm{c}$ $1 / 2$. Oz., $25 \mathrm{c}$.

M. A. Hull, Iogan Co., Ohio, writes, April 4, 1918:

"Your Stone Tomatoes that I got last year were far superior to anything I ever raised; also those Manyfold are very fine; had better luck with all your seeds than have had from any other house.

Wilmer F. Short, Kent Co. Dela., writes: "Last year used the Livingston Stone and found it all $\mathrm{O} . \mathrm{K}$. I always grow ten acres of tomatoes for the Canning Factory, and find the Stone all right.

Rebeca White, Gadsden Co., Fla., writes as follows: Your seeds are wonderful. My garden last year was a urprise to myself. Especially fine were my Tomatoes." John Wm. Watson, Fulton Co., New York, writes as follows: "I had the best Tomatoes last year that I have ever raised in this climate, "Livingston's Perfection." I am enclosing $\$ 1.00$ for small order. I hope that you can ship it at once."

\section{Greater Baltimore}

A mid-season red variety, very heavy, due to its extreme firmness and very thick meat. Fruit ripens evenly: free from ridges and cracks. A good canning sort. Pkt. 5 c.; $1 / 2$ oz., 30 c.; Oz., 50 c.; $1 / 4$ lb., $\$ 1.60 ;$ lb., $\$ 5.75$.

C. B. Carpenter, Iabette Co., Kans., writes as follows: i ordered my Tomato seed from you last year. The seeds came well but the hot, dry weather got away with about all except the Manyfold, which stood the heat and drougth remarkably well. I would like my order filled soon, as we grow Tomato plants in hot beds for the public. Many people go wild over your Glube Tomatoes, and we think they are fine."

\section{Small Fruited Tomatoes}

Excellent for Preserves, Pickles and Pies

Red Currant-Smallest of all sorts. Pkt., $5 \mathrm{c}$; $1 / 2 \mathrm{oz}$. $25 \mathrm{c}$.

Red Pear-Pkt., 5c.; $1 / 2$ oz., 25c.

Yellow Cherry-Pkt., $5 \mathrm{c}$. ; Oz., $25 \mathrm{c}$

Red Cherry - Pkt., 5c.; $1 / 2$ oz., $25 \mathrm{c}$.

Yellow Pear-Pkt., 5c.; $1 / 2$ oz., $25 \mathrm{c}$.

Yellow Plum-The finest of the small varieties. Pkt. 5c.; $1 / 2$ oz., $30 \mathrm{c}$.; oz., 50c.

Mixed Small TomatoesAbove 6 sorts. Pkt., 10c

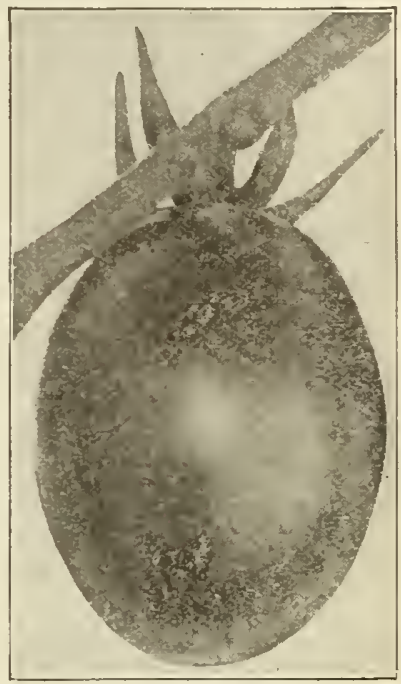

Yellow Plum

\section{GROW BUMPER CROPS}

INOCULATE YOUR ALFAIFA, CIOVERS, COW PEAS, SOY BEANS, VETCHFS AND ALI OTHER IFGUME CROPS WITH

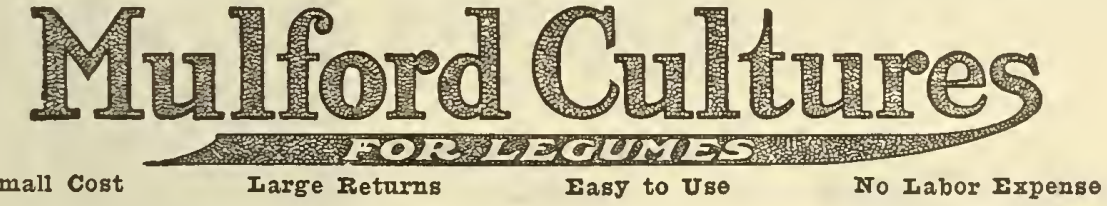

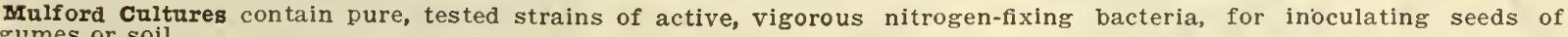
egumes or soil.

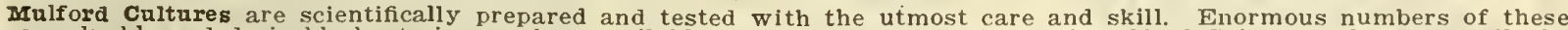

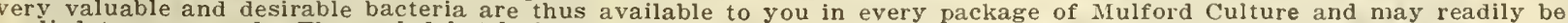
applied to your seed. The sealed bottle insures purity.

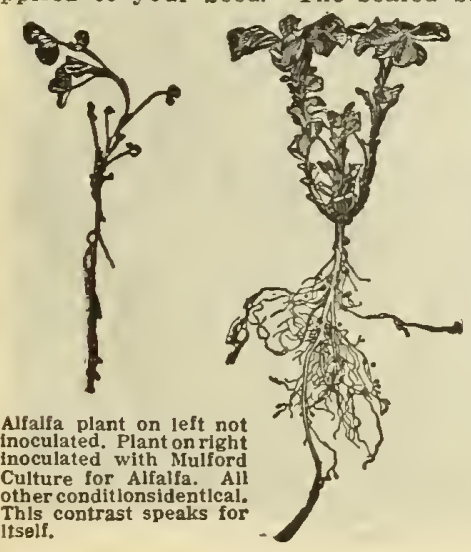

Iegumes offer the best-known means of maintaining soil fertility and rejuvenatng over-cropped and worn-out fields. They add both humus and nitrogen to your soil and thus increase your yield of wheat, cotton, corn and other non-legume crops.

The U. S. Department of Agriculture and many State Agricultural Experiment Stations recommend inoculation of legumes with nitrogen-fixing bacteria to induce a prompt "catch" and increase your yield.

Mulford Cultures are only prepared for

ALFALFA ALSIKE CLOVER VETCH

CRIMSON CLOVER BURR CLOVER VELVET BEANS

SIVEFT CLOVER

RED CLOVER SOY BEANS

SOY BEANS

SWEFT PEAS

GARDEN PEAS

GARDEN BEANS
LIMA BEANS

LESPEDEZA

BEGGAR WEED

and others

Always specify on your order what crop you want to inoculate, as there is a different strain of bacteria for each legume.

PRICES: 5-Acre Size

1-Acre Size

Small size (Supplied only in four yarieties, for

Garden Peas, Garden Beans, Lima Beans and and Sweet Peas).

These prices include delivery. 


\section{Livingston's Re-Cleaned Clover Seeds}

Partles wishing large quantities will do well to get samples and prices before placing their orders. We handle it on a close margin and supply the finest grades. It is impossible to tell how low our prices are without seeing samples, which will be sent free on application. A bushel of Clover Seed is 60 pounds. Pound prices are postpaid. In larger quantities, by Parcel Post, express or freight, purchaser pays the transportation charges. For Parcel Post rate, see page 3.

All prices on Clover and Grass Seeds are subject to market changes and would suggest that you write for prices before ordering.

Medium, or Common Red-The most important and valuable of the clover family. Makes the best of hay. Sow 10 lbs. per acre. Lb., $80 \mathrm{c}$., postpaid. By freight or express, not prepaid: $10 \mathrm{lbs}$., $\$ 6.75 ; 50$ ibs., $\$ 32.70$; 100 lbs., $\$ 63.35$.

Mammoth Clover-Valuable with other grasses for mixed hay. Ripens about with Timothy. Being a rank grower it is used largely for plowing under. Sow 10 lbs. per acre. Lb., 80c., postpaid. By freight or express, not prepaid: 10 lbs., $\$ 6.75 ; 50$ lbs., $\$ 32.70 ; 100$ lbs., $\$ 63.35$.

Crimson Clover-Should be sown in July, August and September of each year. Can be sown with corn, or any cultivated crop. Sow 10 to $15 \mathrm{lbs}$. per acre. Cover lightly. Use only American grown seed. The Spring following it can be cut for soiling May 1st; for ensilage, May 1 to 15; for seed, about third week in June. Lb., 40c., postpaid. By freight or express, not prepaid: 10 lbs., $\$ 2.65 ; 50 \mathrm{lbs}$., $\$ 12.45 ; 100$ lbs., $\$ 23.35$.

White Dutch Clover-Good in permanent pastures, especially for cattle; valuable for bees, and the best variety for lawns. Sow in spring at the rate of $5 \mathrm{lbs}$. per acre when sown alone; $1 / 2$ the quantity when sown with other grasses. Lb., 85c., postpaid. Bv freight or express, not prepaid: 10 lbs., $\$ 7.50 ; 50$ lbs., $\$ 36.00 ; 100$ lbs., $\$ 70.00$.

\section{Sweet Clover or Bokhara}

Melilotus Alba (White), Melilotus Officianlia (Yellow) are Biennial; Melilotus Indica (Yellow), Annual.

Are the varieties in general use. The white-flowered variety (Melilotus Alba) is the one we handle unless otherwise mentioned. It is the strong. est grower and by far the best.

When young it resembles Alfalfa, but when mature it often stands 5 to 8 feet high and blooms from June to October. The roots of all varieties are large and much branched and penetrate the ground several feet. Being the Biennial, all top and roots die at the end of the second year if the plant ripens seed.

If cut before seed is ripe, or if pastured so that seed is not matured, the plants lasts over several seasons.

Is found growing under very varied conditions of both soil and climate. It, however, prefers a limestone soil and has been largely used to reclaim old, worn-out, abandoned lands. It is of great value for this purpose.

Apart from its value as a nitrogen gatherer and humus producer sweet Clover is rapidly coming to the front as a hay and pasture crop its feed value is nearly equal that of Alfalfa, and in a short time stock eat it as readily as they do Red Clover and seem to thrive on it equally well. For hay cut just before it comes into bloom, and is handled as you would Alfalfa. It is also used extensively as a Bee pasture, the small white blooms yield much fine honey.

Sow clean hulled seed at the rate of 15 to $20 \mathrm{lbs}$. per acre, from April Sept. 15th, with or without a nurse crop.

Price-Lb., 65c., postpaid. By freight or express, not prepaid: 10 lbs.,

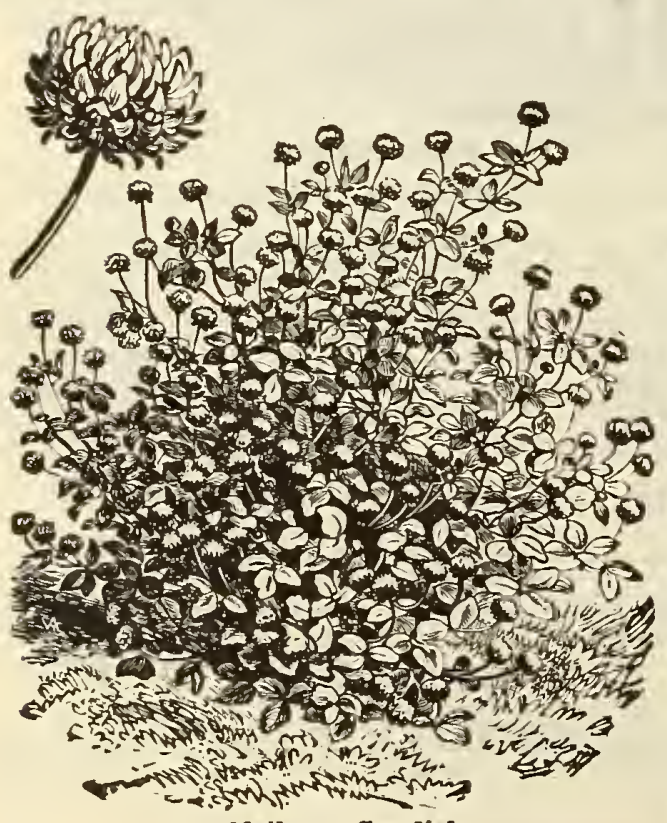
$\$ 4.30 ; 25$ lbs., $\$ 11.00 ; 50$ $\$ 40.00$.

\section{Alsike, or Hybrid (Swedish)}

Hardest of all clovers. On rich, moist soil, yields large quantities of hay or pasturage. Will thrive in soils which are so wet that the Common Red Clover would not live. Unlike some of the other clover, which have tap roots, Alsike has many fibrous roots, hence is not injured by freezing and thawing of the ground. Esteemed highly by bee-keepers. Sow 5 lbs. per acre. Lb., $15 \mathrm{c}$. , postpaid. By freight or express, not prepaid: 10 lbs., $\$ 6.40$; 50 lbs., $\$ 31.25 ; 100$ lbs., $\$ 61.70$.

Prices Subject to Market Alatie or Swedish change

Notice-Do not forget to include innoculator with your order for clover and increase your chances for bumper crops. See page 49 for description and price.

A Satisfied Castomer for 31 Years Mr. Ellsworth Fay, Iicking Co., Ohio, writes: "Will it be possible for you to furnish me select seed of your Livings ton's Mangus Ponderosa Tomato and Livingston's Golden Surprise Corn? Have planted your seeds since 1888 and have no reason to eliminate them from my garden."

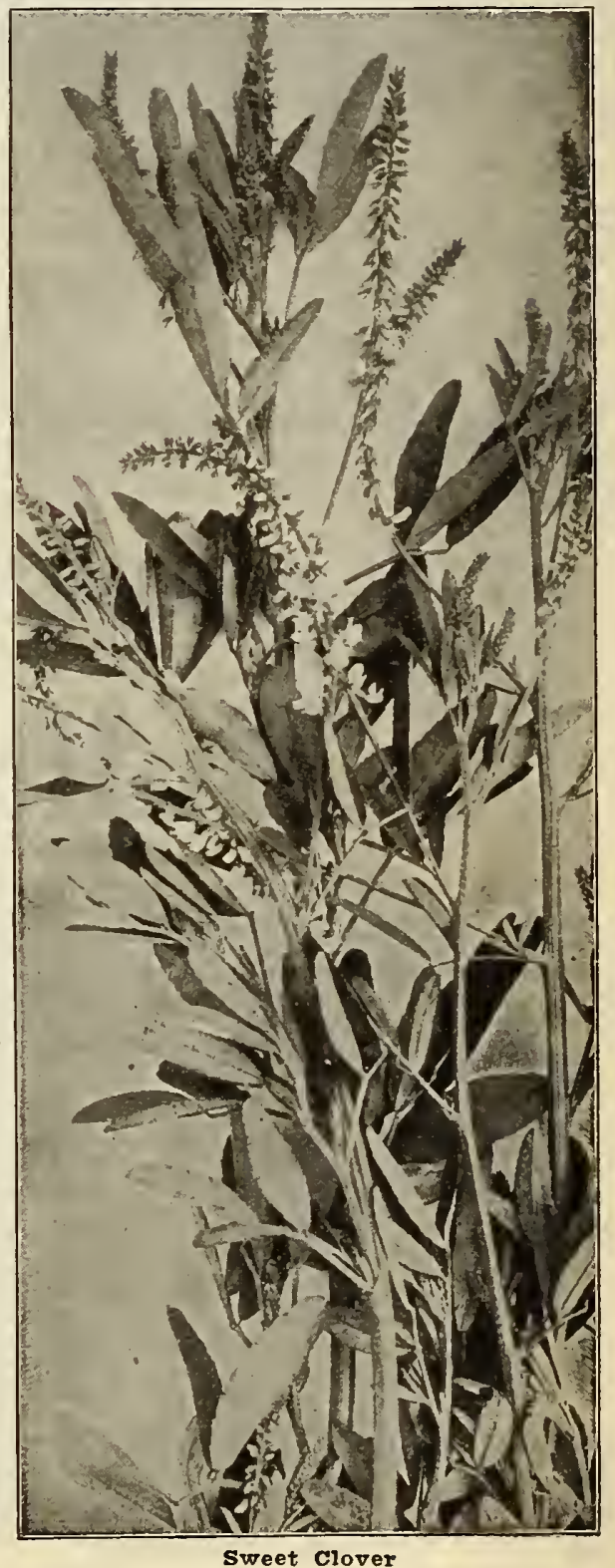




\section{Alfalfa or Lucerne (Medicago sativa)

\author{
The Greatest Feed on Earth
}

Alfalfa is being more generally grown as experience is teaching our farmers the proper methods to follow. Different soils do not now seem so difficult to overcome, especially where they can be properly drained, pulverized sweetened and inoculated.

Alfalfa does not thrive on acid or sour land, nor will it a its best witbout inoculation on any kind of soil.

Treat your land to liberal dressing of fine ground lime or more liberally to fine ground limestone well worked into the soil some three months to a year before seeding to Alfalfa.

Sow from 10 to 15 lbs well inoculated seed per acre using vitrogen. From Auril 1st to June $15 \mathrm{th}$ for the uring sowing either drilled or sown broadcast. ear broadcast cover lightly with a light drag or with single stroke of a harrow.

Alfalfa naturally prefers a deep sandy or gravelly subsoil. Roots from 2 to 15 feet deep, and a good stand on properly selected land should yield from 3 to 4 cuttings a year. We make a specialty of extra high grade seed that tests 99 ner cent, pure or better. Get our samples and prices before ordering. Prices: Lb., 60c., postpaid. By freight or express, not prepaid: 10 lbs., $\$ 4.60$; 50 lbs., $\$ 2.75 ; 100$ lbs., $\$ 43.35$.

\section{Re-Cleaned Grass Seeds}

Our Grass and Cover Seeds are selected with special reference to their quality. Purchasers may rely upon our best exertions to furnish them with fresh, pure seed and free from noxious weeds.

Prices on Grass and Clover Seeds are changing almost daily, AND WE CAN ONIY GIVE PRICES SUBJECT TO FIUCTUATIONS. No charge for bags at prices quoted below. Pound prices are postpaid. In larger quantities by Parcel Post, Express or Freight, purchaser pays the freight. See page 3 for Parcel Post Rates. Owing to the European War, prices on imported seeds are more unsetor for larger quantities, write for special rates.

\section{Best Grasses}

Awnless Brome Grass (Bromus inermis)-Will stand long droughts and still produce heavy crops in dry secn a wider range of temperature than any other grass. Sow from 25 to 30 lbs, per acre. (Bu. 14 lbs.) Lb., $45 \mathrm{c}$., postpaid. By express or freight,

\section{Kentucky Blue Grass}

(Poe Pratensis)-Also called June Grass. This famous grass is well known in all sections and where the land is suitable is one of the most profitable of all for pasture. It generally grows well on any stiff or loamy soils in Central and Northern States, and succeeds fairly well in some sections of the South where lime is present in the soil. Kentucky Blue Grass is at its best in the Spring and Fall months. It grows very slowly at the start, but when once established forms a close, compact turf, making a fine pasture, and is most excellent for lawns. It issown at the rate of 1 to 2 bushels for pasture, and 4 to 5 bushels for lawn purposes per acre. Price: Lb., 45c., postpaid. By freight or express, not prepaid: $10 \mathrm{lbs}$., $\$ 3.60$; 50 lbs., $\$ 17.00 ; 100$ lbs., $\$ 32.00$.

Creeping Bent Grass (Agrostis stolonifera)-Excellent for pasture when mixed with other grasses. Succeeds well in most sections and thrives in moist land. Sow 40 lbs. per acre. (Bu., 14 lbs.) Ask for prices.

Rhode Island Bent Grass (Agrostis canina)-Valuable for lawns. Sow 35 to 50 lbs per acre for lawns, 20 to 30 lbs. for pasture. (Bu., 12 lbs.) Ask for price.

Crested Dog'g Tail (Cynosurus cristatus)-May be sown on lawns; forms a close turf, remaining green for a lons time: valuable for sheep pasture: succeeds on dry, hard and gravelly soil. Height 1 to $1 \frac{1}{2}$ feet. Sow 25 lbs. per

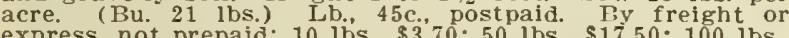
express, not prepaid: 10 lbs., $\$ 3.70 ; 50$ lbs., $\$ 17.50 ; 100$ lbs., $\$ 34.00$.

Meadow Fesctu (Festuca pratensis)-Thrives in all soils; excellent for permanent pastures: starts early. productive. Sow 25 to 35 lbs. per acre. (Bu., 24 lbs.) Ask for prices.

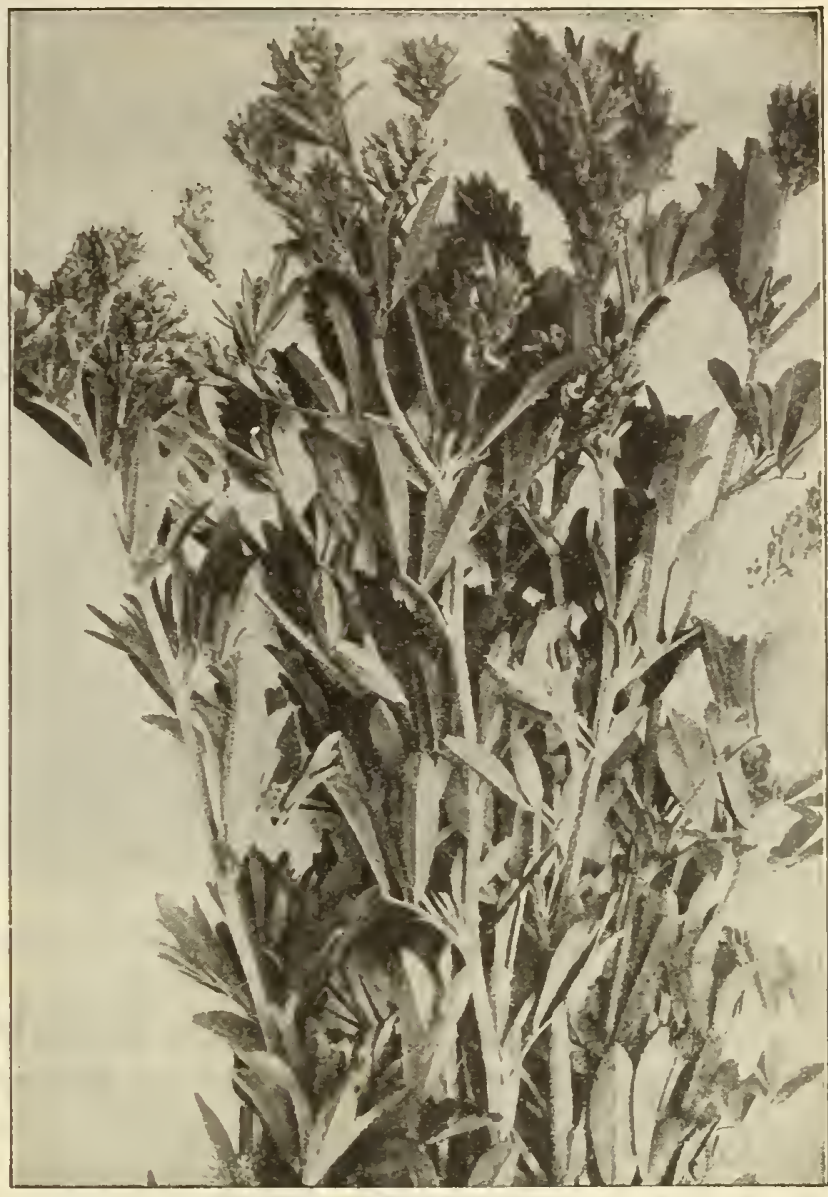

Alfalfa Plant

Orchard Grass (Dactylis glomerata)-Extremely hardy and widely known. One of the earliest to start in the Spring; grows rapidly; furnishes an abundance of pasture the entire season. "Sow 20 to 30 lbs. per acre. (Bu,, 14 lbs.) Lb., 50c., postpaid. By freight or express, not prepaid: 10 lbs., $\$ 3.60 ; 50$ lbs., $\$ 17.00 ; 100$ lbs., $\$ 32.00$.

Perennial Rye Grass (Lo11um perenne)-Very nutritious; valuable for meadows or permanent pastures; rapid grower. Sow 25 to 35 lbs. per acre. (Bu., 24 lbs.) Lb., $40 \mathrm{c}$., postpaid. By freight or express: $10 \mathrm{lbs} ., \$ 2.30 ; 50$ lbs., $\$ 10.50 ; 100$ lbs., $\$ 20.00$.

Sheep Fescue (Festuca ovina)-Grows naturally on light, dry sandy soils and mountain nastures: considered valuable mixed with other grasses for permanent early Spring pasture. Sow 15 lbs. per acre. (Bu., about 12 lbs.) Ask
for prices.

Red Top Grass-(Agrostis Vu1gaHs)-Particularly well suited to low and wet situations, but will do well on all classes of soil. Affords splendid pasturage and a fair crop of hay, ripens about with timothy, forms a firm sod and is a valuable grass for lawns and on lands subject to overflow and wash. (Bu., 14 lbs.) Fancy clean seed. Lb., $40 \mathrm{c}$, postpaid. By freight or express, not prepaid: $10 \mathrm{lbs}$.
$\$ 2.60 ; 50$ lbs., $\$ 12.50 ; 100$ lbs., $\$ 23.50$.

Timothy (Phelum pratense)-As a crop to cut for hay, Timothy is probably surpassed by no other grass now cultivated. If sown alone it requires 8 to 12 pounds per acre. of our specialties. Write us for, latest prices, whether you want a bag or a carload. (Bu., $45 \mathrm{lbs}$.) Prime Seed: Lb., 30c., postpaid. By freight or express,
not prepaid: 10 lbs., $\$ 1.75 ; 50$ lbs., $\$ 7.75 ; 100 \mathrm{lbs}$., $\$ 14.50$. Choice Seed: Lb., $30 \mathrm{c}$., postpaid. By freight or express, not prepaid: $10 \mathrm{lbs}$., $\$ 1.90$; 50 lbs., $\$ 8.00 ; 100 \mathrm{lbs}$., $\$ 15.00$.

Wood Meadow Grass (Poa nemoralis)-Adapted for pasture or pleasure grounds; of early growth; thrives under trees. Sow 25 to 30 lbs. per acre. (Bu., 14 lbs.) Ask
for nrices. 


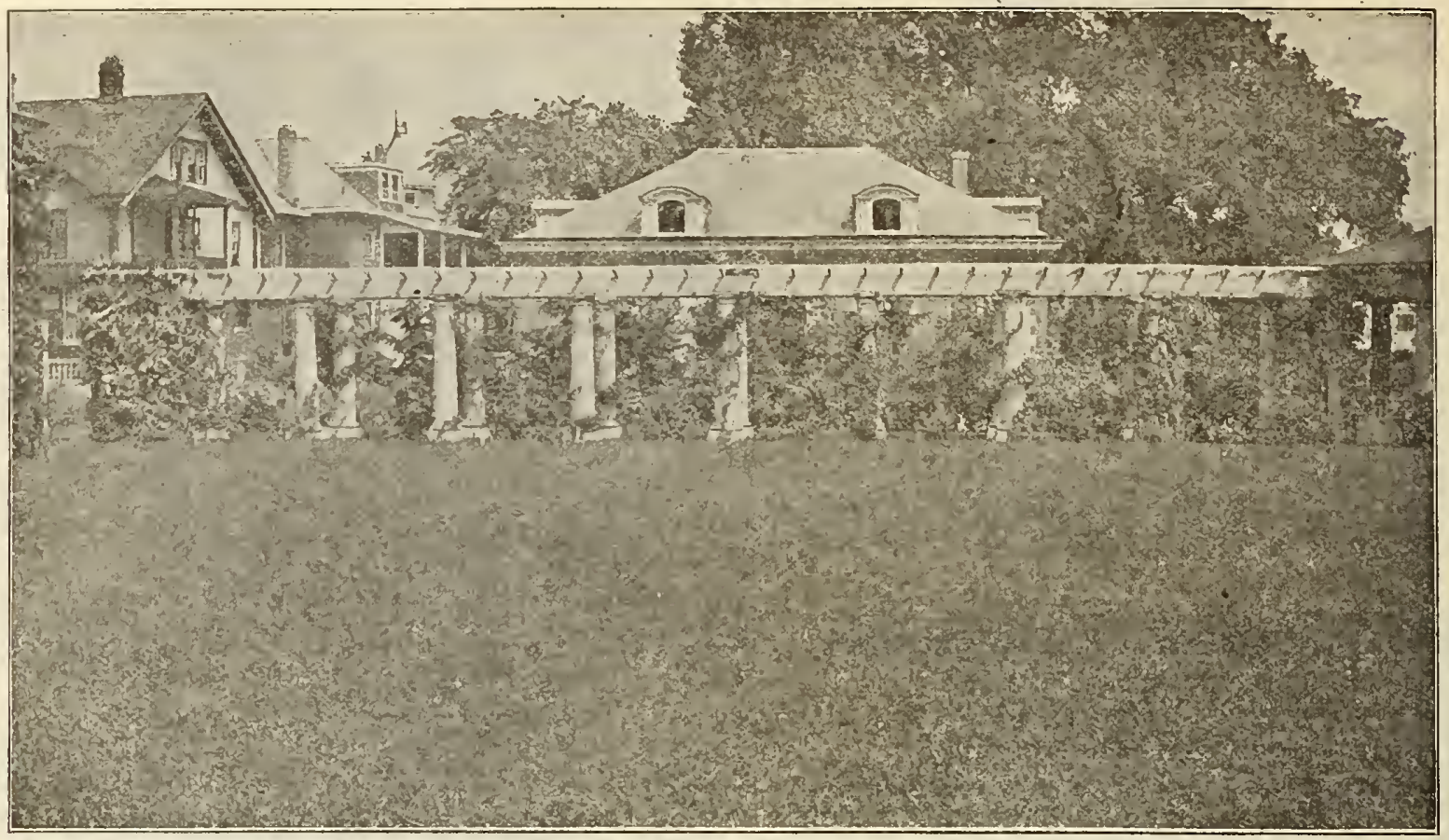

\section{The Lawn Problem Solved by the Use of Livingston's Lawn Grass Seed SOWN IN SPRING OR FALL}

\section{Livingston's Capitol Lawn Seed}

It contains only the highest grade of grasses suitable for the purpose of making a beautiful, durable, lasting lawn. It greminates quickly and roots deeply. This enables it to withstand the intense heat of summer and the hard cold of winter, showing a beautiful rich green. It contains no annual grasses for making a quick show, to the detriment of a permanent lawn, but has only those which are lasting and hardy. When a lawn is once established from our seed, it lasts for years. From six to eight weeks' time is all that is required to form a close, thick turf of rich, velvety green TVe have made the formation of lawns a careful study, and many of the finest lawns and grass plots all over the United States were made from Livingston's Capitol Lawn Grass Seed. For a perfect and enduring lawn of closely interwoven, firm, elastic turf, which will flourish under varied conditions of soil and climate and show a luxuriant rich green growth throughout the year, plant Livingston's Capitol Lawn Grass Seed. It is the cheapest as well as the best lawn grass seed offered. While $14 \mathrm{lbs}$. of lawn grass seed is usually considered a bushel, this will weigh $20 \mathrm{lbs}$. to the bushel. We sell by the pound instead of quart. This method is very much to the advantage of the purchaser, as a pound of grass seed measures over $1 \frac{1 / 2}{2}$ quarts. Lb., $55 \mathrm{c}$; 3 lbs., $\$ 1.50$, postpaid. By express or freight, not prepaid: 5 lbs., $\$ 2.00 ; 10$ lbs., $\$ 3.75 ; 25$ lbs., $\$ 8.75 ; 100$ lbs., $\$ 30.00$.

\section{“Quick Grower” Lawn Seed}

We prepare a special mixture that will give quicker results than our Capitol Lawn Seed, yet it makes a good lasting lawn. If you have tried others and failed, give this a fair trial, and we feel sure you will be pleased with the results. $1 \mathrm{lb}$. to $300 \mathrm{sq}$. ft. Lb., $55 \mathrm{c}$. : 3 lbs. $\$ 1.50$ postpaid. By express or freight, not prepaid: 5 lbs., $\$ 2.00$ 10 lbs., $\$ 3.75 ; 25$ lbs., $\$ 8.75 ; 100$ lbs., $\$ 30.00$.

\section{Shady Place Mixture}

On nearly all lawns there are shaded, bare, and unsightly spots on which the owners have difficulty in getting a stand of grass. For such places this mixture is adapted. It is composed of grasses which naturally grow in shaded places. They are the finest and most costly of all grasses. If the soil is covered with moss or seems "sour" and out of condition, rake off the surface and apply hydrated lime at the rate of $100 \mathrm{lbs}$. to 1,000 square feet; this will sweeton the soil. Lb., 75c.; 3 lbs., $\$ 2.10$, postpaid. By express or freight, not prepaid: 5 lbs., $\$ 3.25 ; 10$ lbs., $\$ 6.25 ; 25$ lbs., $\$ 15.00$.

\section{Tennis-Court Mixture}

A mixture composed of low-growing hardy grasses suitable for grounds of this kind. Lb., 75 c.; 3 lbs., $\$ 2.10$, postpaid. By express or freight, not prepaid: 5 lbs., $\$ 3.25$; 10 lbs., $\$ 6.25 ; 25$ lbs., $\$ 15.00$.

\section{Golf-Link Mixture}

We make a mixture of grasses suitable for the purposes of golf links, so it will stand rough usage. We can also prescribe for links located on poor or rich, dry or wet soils, telling which grass will best suit each location.

\section{Kentucky Blue Grass}

Many prefer plain Blue Grass to a mixture, and it cannot be denied that it produces a beautiful and lasting lawn. It takes longer, however, to get established. For fuller description see page 51. Fancy clean seed. Lb. 55 c.; 3 lbs., $\$ 1.50$, postpaid. By express or freight, not prepaid: 5 lbs., $\$ 2.00 ; 10$ lbs., $\$ 3.75 ; 25$ lbs., $\$ 8.75$.

\section{Mixed Grasses}

For Meadows and Permanent Pastures-We are prepared to furnish seeds adapted to all soils, all situations and all purposes-for light, medium and heavy soils. By light soils we mean that which is more or less of a sandy or gravelly nature; the heavy, clay and heavy loams, while

the mcdium is between these two. A light, wet soil may be considered same as for heavy soils; a dry, heavy soil, same as the light soils. Write us what you want, giving nature of soil, number of acres, etc., and we will, with pleasure, give you estimate and terms.

PRICSS SUBJEST TO MARRET CHANGES. Write for prices on larger quantities.

SPECIAL QUOTATIONS. We are always pleased to quote special prices to parks, institutions, golf clubs, and others who require Lawn Grass Seed in large quantities. On request will send booklet on lawns. 


\section{Sand or Hairy Vetch}

One of the Newer Leguminous Plants of Value

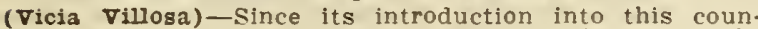
try this plant has made a splendid reputation for itself, especially as a crop to turn under. It succeeds on almost all soils, even poor sand soils produce quite good crops, though it is much more vigorous on good land. It is rery hardy and remains green all Tinter. It should be sown during tugust and September, and we advise that it be sown with rye-the rye helps to hold it up. It is much hardier than scarlet Clover and is giving excellent returns in the Northern and Northwestern states where the Winters are very severe and where many forage plants Winter kill. It is equally valuable in the South for a hay crop. Every gardener, dairyman and farmer should use this wonderful soiling plant.

T'here conditions of soil, time of sowing, and rainfall have been favorable, it will make from 10 to 15 tons of green top to turn-under by the first to the 15th of Mlay

The root system is quite heary and like all leguminous plants bear to a greater or less extent nitorgen gauls or hodules according to season, land and inoculation.

If the crop is to be used for hay, it will be well to sow 45 to 60 ibs of Tetch, and with it $1 / 6$ bu. Rye per acre. Write for circular giving fuller culture directions.

If you want any considerable quantity, write for special quotations.

Tetch is largely gromn in Europe, and on account of the war seed is scarce.

Price-Oz., 5c.; 4 ozs., 20c.; lb., 60c.; Postpaid. By express or freight, not paid: 10 lbs., $\$ 450 ; 25$ lbs. $\$ 11.00$ 50 lbs., $\$ 21.50 ; 100$ lbs., $\$ 2.00$.

\section{For NITROCULTURE INOCULATOR, See Page 49}

\section{Tree 羿 Hedge Plant Seeds}

\section{Osage Orange-The best of all hedge plants. Oz., 10c.} 1/4 lb.p $30 \mathrm{c}$.; postpaid.

\section{Catalpa (Speciosa)}

A rapid grower and makes the best timber trees. Pkt., 5 c.; oz., $20 \mathrm{c}$; $1 / 4$ lb., 50c., postpaid.

\section{Russian Mulberry}

Easy grown; hardy; tine tor hedges; makes fence posts in five years; fruit good. Pkt., $10 \mathrm{c}$; $0 \mathrm{z} ., 30 \mathrm{c}$; $1 / 4 \mathrm{lb}$., $85 \mathrm{c}$., postpaid.

\section{Black Iocust}

A very rapid grower, as ience posts or ties may be cut in 10 years from planting seed, and will last a lifetime. Oz.. 10c.; $1 / 4$ 1b., $40 \mathrm{c}$., postpaid by freight or express, 10 lbs., $\$ 10.00 ; 25$ lbs., $\$ 23.75 ; 50$ lbs., $\$ 45.00$.

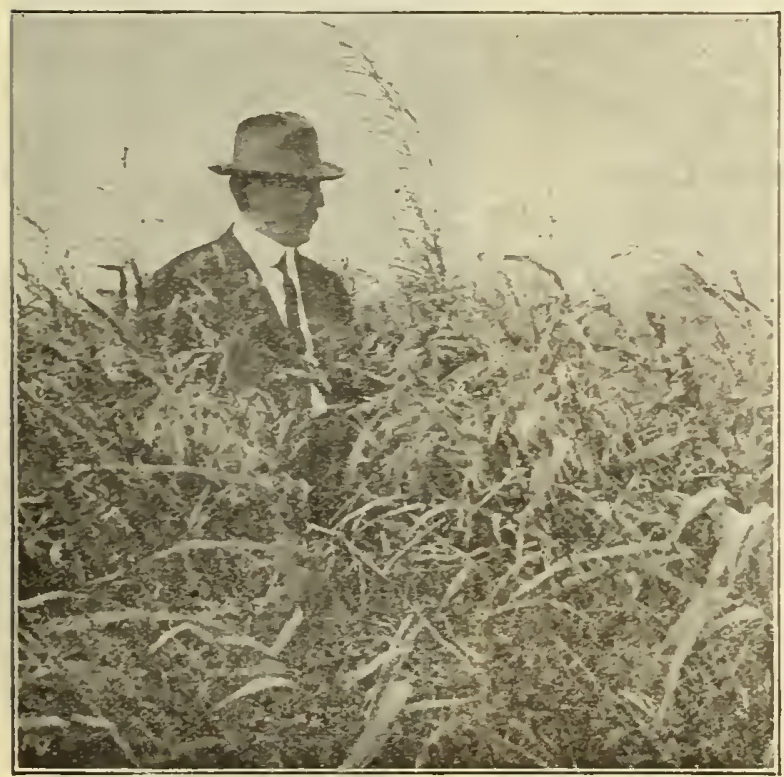

Photograph supplied by Southwest Trail sedan Grass

\section{Spring Vetches}

A good forage plant; also used for plowing under. Sow 50 to 75 lbs to the acre broadcast like wheat or barley Prices: Oz., 5c.; 4 ozs., 15c.; lb., $25 \mathrm{c}$; ; postpaid; by ex press or freight. not paid: 10 lbs., $\$ 1.60 ; 25$ lbs., $\$ 3.75 ; 50$ bs., $\$ 7.00 ; 100$ lbs., $\$ 13.00$

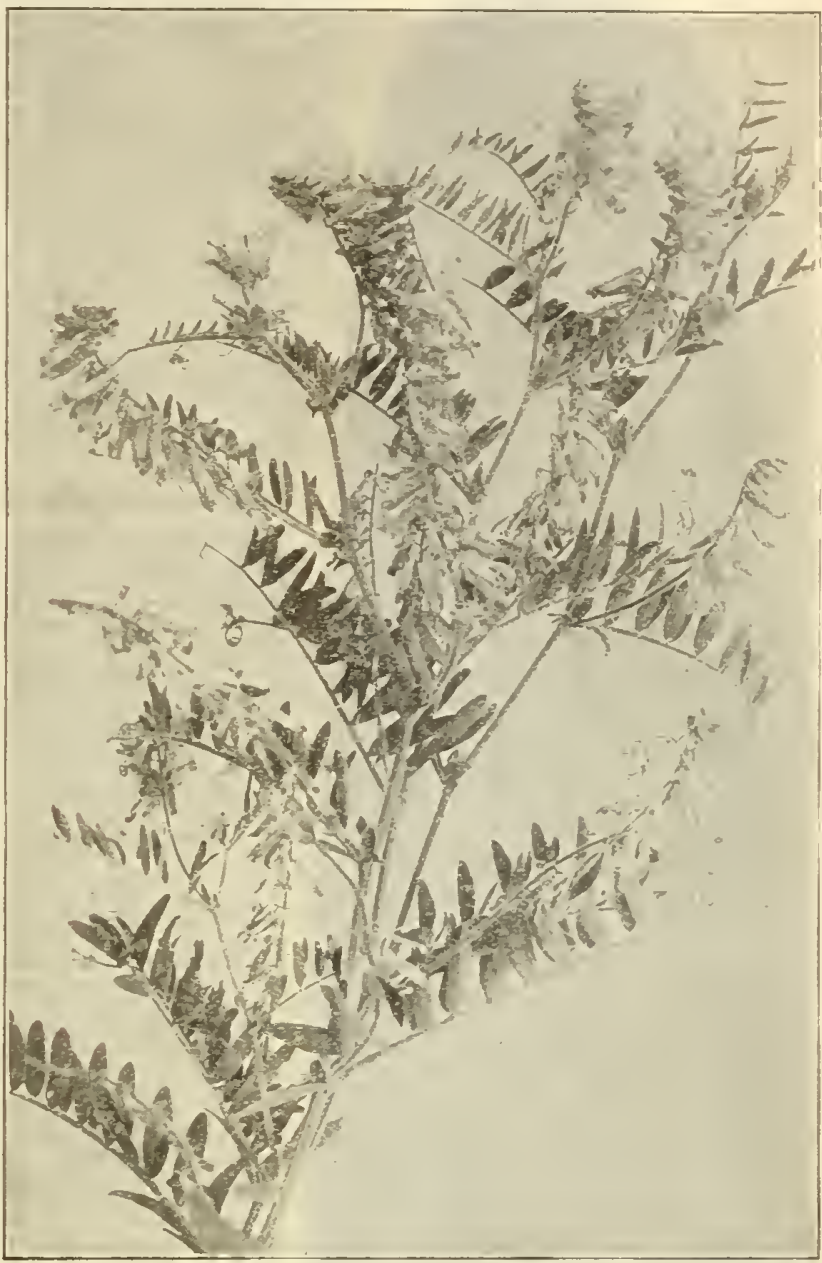

Plant Flairy Vetch

\section{Sudan Grass}

A New Forage Crop of Immense Value to the South and Midale West

The dry region has no other satisfactory hay crop and Sudan Grass will be of great value there.

sudan Grass is strictly an annual and dies each year like Millet. This makes it fit into any system of rotation.

Sudan Grass grows 5 to 9 feet tall. The stems are very small, rarely thicker than a lead pencil

The plant stools freely when given plenty of room, and often produces 100 stems from one crown. The tendency to stool is greater after the flrst cutting, and the hay is iner from the second cutting.

Sudan Grass is not very particular as to soil but does best on rich loam, fairly well drained.

In seeding Sudan Grass, a firm seed bed is best and should not be sown until the soil is well warmed up. The best tool for seeding is the cominon grain dill, and seed should be covered from half inch to one inch. When drilled W rows 18 to 24 inches apart, 4 to 6 pounds are requiled. used. Price-Large Pkt., 10c.; 1 lb., 40c., postpaid; by used. Price-Large Pkt., 10c; ; lbor., $\$ 2.15 ; 25$ lbs., $\$ 5.00$ 50 lbs., $\$ 9.50 ; 100$ ibs., $\$ 18.00$. 


\section{Livingston's Thoroughbred Field Corn Seed}

Prices of all Farm Seeds quoted in this Catalogue are subject to market changes. The prices given are those ruling at the time this Catalogue is published, January Ist. But we reserve the right to change prices without notice.

Fifty-six pounds of Field Corn Seed will plant five and one-half to seven acres, according to variety and whether the hill or drill method of planting is followed. Livingston's Thoroughbred Field Corn Seed only costs you 70 to 80

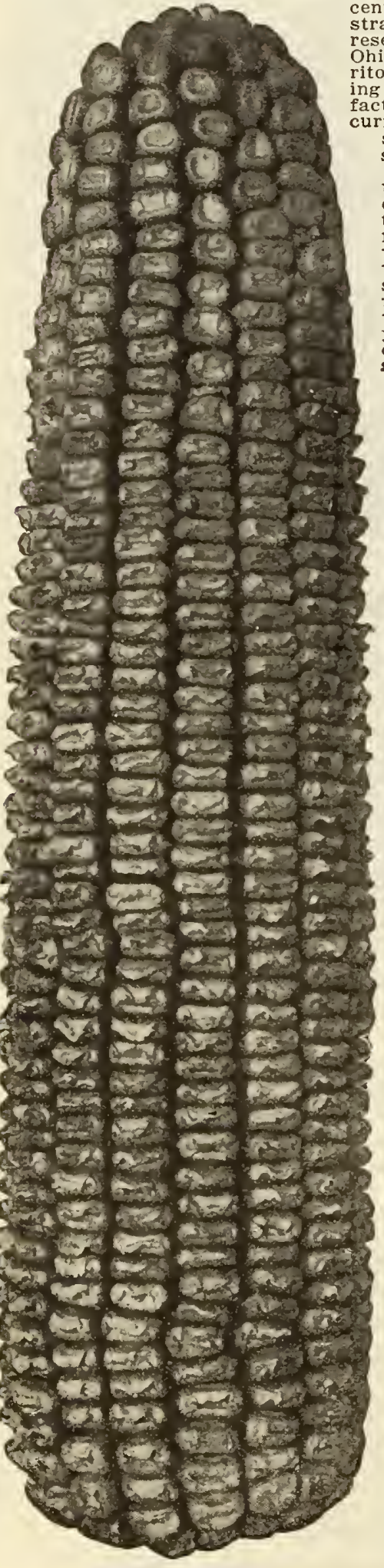

Golden Surprise strains are pure and each a distinct type-no two resembles one another, and all grown in Central Ohio. Situated, as we are, in the very best territory in this country, for growing and perfectfact that our facilities and opportunities for securing and supplying the most thoroughbred seed firm.

All our Field Corn Seed is well matured, thoroughly cured, and shelled with the greatest care. We test all varieties before sending the seed to our customers, that there may be
no doubt as to the vitality. To avoia delay when ordering late in the season, it would be well for you to mention your second choice, or state whether we shall send you a sort adapted vided we are sold out of your first choice when your order arrives. Field corn seed on the ear can only be supplied while our present stock lasts.

\section{Livingston's Golden Surprise}

The Iarge Amount of Corn Produced on Such Small Cobs Surprises Everyone. Entirely Distinct. Stalks Short and Strong. Ripens in 90 to 100 Days. Ears Medium Size. Deep Grained, Small Cob. A great Feeding Corn.

variety of great merit offered and named by us in 1898, and, as anticipated, it has met With great favor wherever it has been tested. Corn consists of plain statements and simple Oacts. illustration is from a plotograph, and will give you an accurate idea of the ears. The Corn as a whole, is indicative of its name, and is indeed a genuine surprise to all who grow it. Beautiful in its rich golden color and even size from butt to tip of the ear. Profitable in its depth of mrain and small per cent of waste in cob. Convenient in its short fodder growth and easy break maturity, and, all points considered, the best early Corn up to date.

Golden Surprise was not offered to the general public until after ten years of the lection careful, critical observation and sefor years in various localities in comparison with well-known $\mathrm{rts}$, we find it equal in average bulk to any on the market but in depth of grain and weight of shelled Corn per growth is vigorous, medium and strong stalk, with broad leaves, which makes it a valuable fodder Corn. For prices, see below.

\section{Neller's Cattle Corn}

This very desirable strain of Corn was brought into Licking County, Ohio, from an adjoining county some thirty or more years ago by a local cattle breeder. And as it was especily well adapted to cattle feeding, befor cattle feeding, but for general use as Our attention was directed to this corn our time since, and eirht Jears aro when good seed corn was so hard to procure we introduced it to our trade through our retail store. Seven years ago we catalogued this variety and reports from all directions to isfactory and we look upon it as one of our very best strains for general growing; quite uniform in shape and style of ear and a sure cropper.

The corn is a good strong yellow in color, but not chaffy set on a small dark red cob. Ears have 12 to 16 rows and often 12 inches long and well-grained over the ends; fodder an average in size and leafage In this 10cality will ripen in 90 to 100 days.

Prices Shelled-Targe Plt., 10c: 1b., 25c.; 2 lbs., 40c., postpaid. By express or freight, not prepaid: $7 \mathrm{lbs} ., 60 \mathrm{c}$; $14 \mathrm{lbs}$., $\$ 1.10 ; 56 \mathrm{lbs}$. 4li 100 lbs., $\$ 7.00 ; 68$ lbs., Ear, $\$ 5.00$.

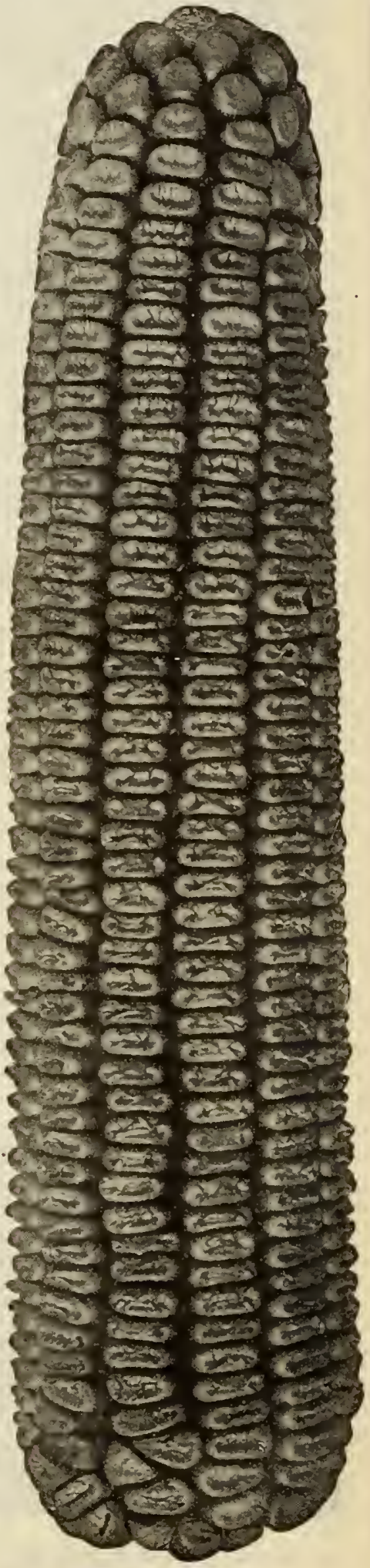

Neller's Cattle Corn 
NOTICE Do not forget that our field corn is all grown in Central Ohio, and fully acclimated. This should not be overlooked in deciding where to place your order.

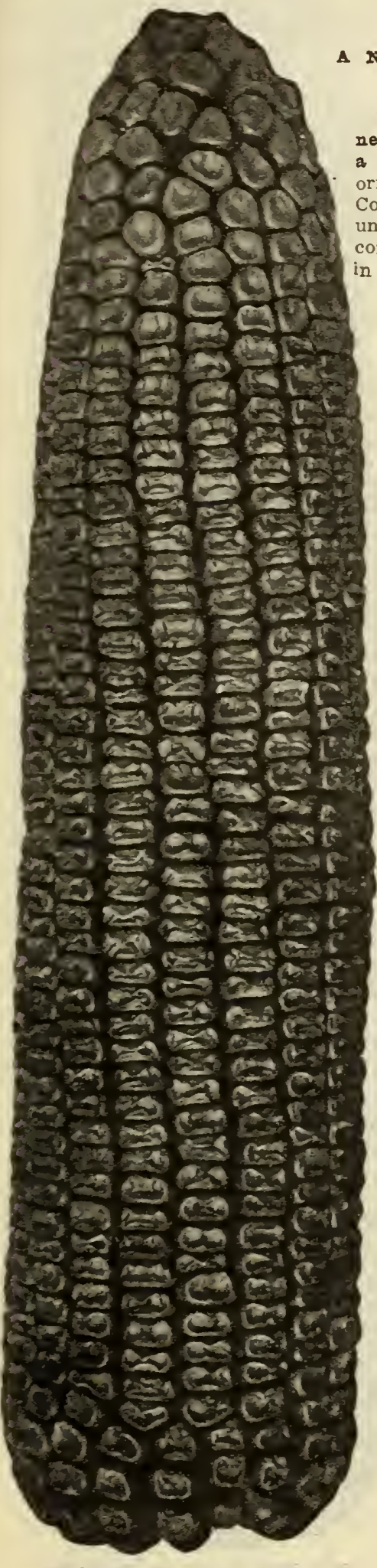

Kilbury's Yellow Hybrid

New and Very Desirable Variety. Earliest Iarge-Eared Corn in Caltivation. Handsome, Uniform Ear.

This splendid Corn is one of the most valuable new rarieties which has come ander our notice for a long time. (See illustration.) The following is originator's description: "Kilbury's Iellow Hybrid Corn is deep in color, with red cob, which tapers uniformly from butt to tip, with deep grains well Ears large, from 9 to 12 inches ground, husks easy; does not fall off in handling. The earliest large Corn on the market. Plant any time in May; it has matured planted as late as June 15 th. This corn has been successfully grown for 20 years on black loam and clay soils, and is well adapted to both."

After careful examination of this Corn, both growing in fields and after being harvested, we believe it to be all that Mr. Kilbury claims. It is the result of careful selection from hybrids, of Leaming and Clarase, but is much larger than either of the parents. It is a large, medium early Corn; safe to plant in localities no colder than Ohio. If you want the earliest big-eared Corn grown, with large, heavy, deep grains and small cob, a yellow corn, plant Kilbury's Yellow Fybria. For prices see below.

\section{Johnson County White Dent}

This variety is a cross between Boone Co. White and Forsythe Favorite and developed and introduced by $L$. B. Clore and has had 25 years of careful, painstaking and intelligent selection and breeding. For the corn-growing belt, we are quite sure there is no White Corn grown today of equal merit. The Corn has become famous for yield and quality and especially valuable where one Wishes to grow show stock.

The shape of the ear is cylindrical to within about 2 inches of the tip, then slightly tapering. Tips fill well over the end and a large per cent of the ears are entirely covered with grains; the butts are Well rounded out with a medium sized shank, kernels very uniform wedgeshaped, pure white, and white cob; ears average about 10 inches in length with the circumference about three-fourths of the length.

Of strong and vigorous habit of growth and well covered with broad bladesvery valuable for ensilage The length of season is about 120 days This corn has been successfully grown as far north as Ft. Wayne, Ind., and Marion, Ohio. corn-growing valley's in latitudes of lumbus and south.

Prices, shelled-Large Pkt., 10c.; 1b., 25 c.; 2 ibs., 40c, postpaid. By express, or freight, not prepaid: 7 lbs., 60c.; 14 Ibs. $\$ 1.10 ; 56$ ibs., $\$ 4.00 ; 100$ ibs., $\$ 4.00$; 68 1bs., Ear, $\$ 5.00$.

As corn prices are made before corn conditions are fully known, those wanting larger quantities will please write for special quotations.

Al1 Pricer subject to Market Changes.

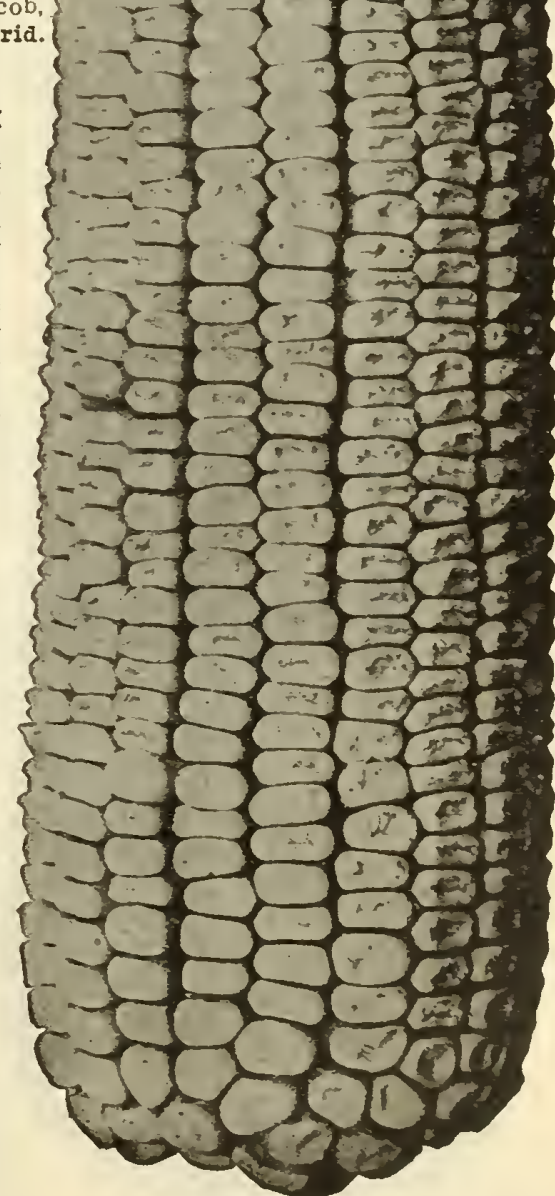

Johnson County White Dent 


\section{Corn (Continued)}

The splendid varieties of Corn described and priced in this catalogue have all been grown especially for seed, and will be found well cured and true to name-in fact, first-class in every respect. We would ask our customers to place their orders as early as possible while our stocks remain unbroken. Frices of Field Corn by Packet and Pound include postage. On large quantities, by Farcel Post, express or freight, purchasers must pay the transportation charges. Seo page 3 for Parcel Post Rates.

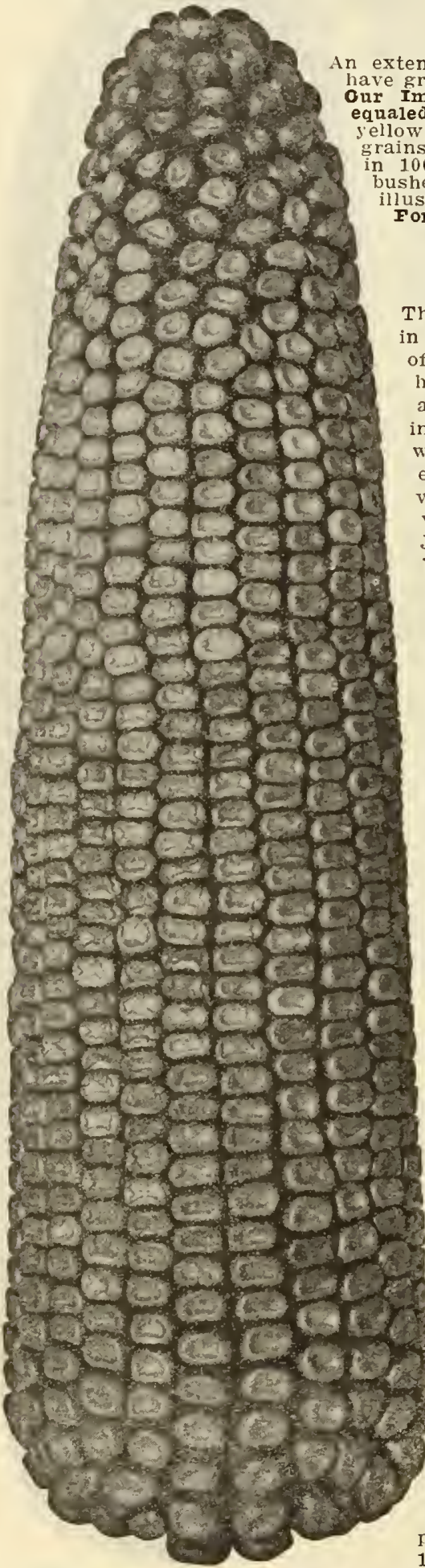

True Yellow Leaming Field Coru

\section{True Yellow Leaming}

\section{The Standard Variety for Quality} ject to prices subextensively grown, large. Yellow Dent variety, which we ar Improved sold with the greatest satisfaction for years equaled, by any other now offered. It has pure. glossy ellow ears growing low, on very strong, heavy stalks; rains square and deep; ripens quite early- frequently bushels per acre Adapted to rich soils. ustration.) or prices, see below.

\section{True Yellow Clarage}

Best Second Early. Sure to Ripen. This variety has been grown extensively in this locality for over 50 years, and is one of the surest cropping varieties ever grown here. Ripens between Pride of the North and True Yellow Leaming. Ear medium in size, very uniform its entire length and well filled out at both ends. Husks very easily; of rich golden yellow color and very productive. In favorable seasons will ripen planted as late as the first of July. Highly recommended as one of the best in points of early maturity, productiveness and very rich in feeding qualities. (See illustration.)

For prices, see below.

\section{White Cap Yellow Dent}

An old popular variety. This old farorite has been known for many years as a good yielder on all kinds of land. A very strong and hardy strain and recommended for thin soils. The ears are large and well covered, cob is both red and white. The grain has white cap, is well dented and of good depth with lemon colored body. Can be planted safely in any part of Ohio and similar latitudes. For prices, see below.

\section{Pride of the North}

A very early Yeliow Dent Fiela Corn, and can be successfully grown farther North than can any other Dent variety. It ripens very readily, even in New England. It also matures perfectly in 90 days and is very frequently safe from frost in 75 days. Very hardy, ears of uniform size; too small for a main crop, but right size for stock feeding; cob small, kernels set closely on cob and are long and compact. This variety is planted quite largely for early crop to feed stock while yet green; and is also planted late when larger varieties could not possibly mature before the frosts.

UNIFORM PRICES FOR AII VARIETIES IISTED ABOVE:

Prices, shelled-Large Pht., 10c.; lb., 25c.; 2 lbs., 40 c., postpaid. By express or freight, not prepaid: 7 lbs., 60c.; 14 lbs., $\$ 1.10 ; 56$ lbs., $\$ 4.00 ; 100$ lbs., $\$ 7.00$; 68 lbs., Ear, $\$ 5.00$.

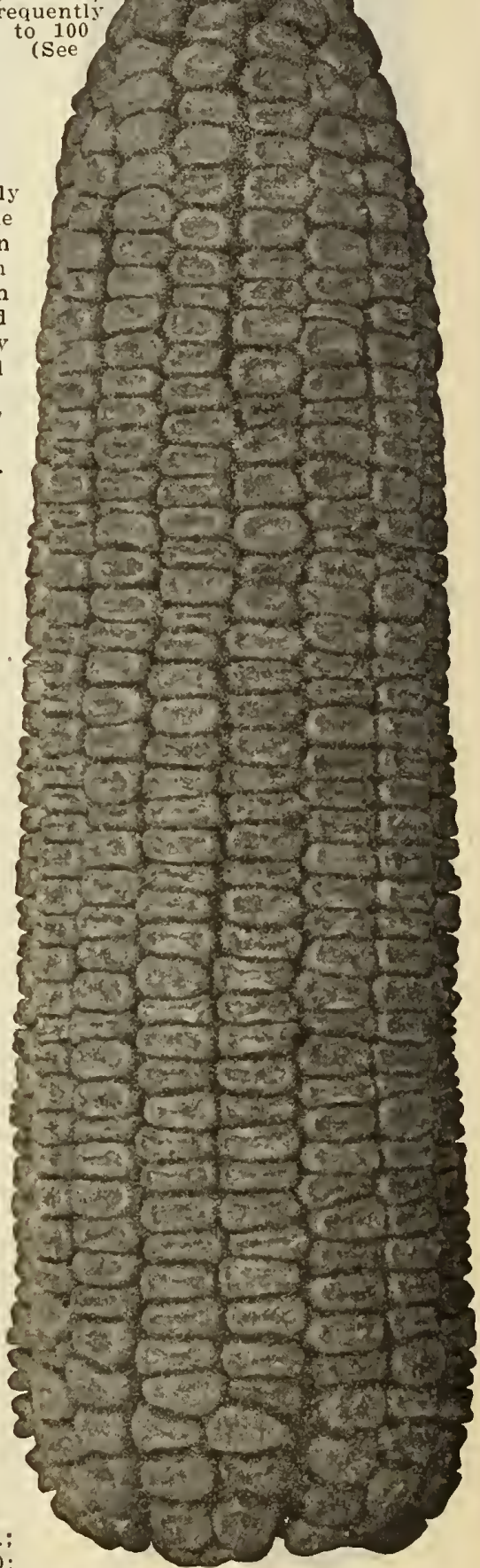

True Yellow Clarage Field Corn 


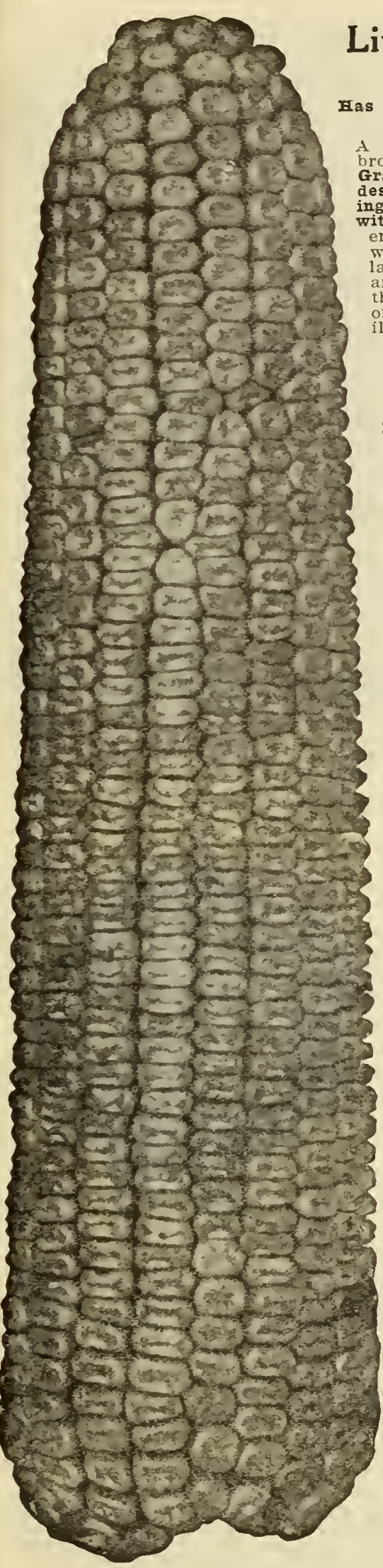

Mammoth White Dent
Livingston's Mammoth White Dent Field Corn

Eas been Grown Continuously on One Farm for

A very large White Dent Field Corn. Has a

Groad, very deep, pure white kernel and cob.

desirable for white cornmeal, and those desir-

ing a large white corn cannot fail to be pleased

this splendid variety. As a grain crop or for

we consider it the equal of any variety

large

round this city and many others throughout

ne of the best large Thite Dent sorts. (See

llustration.) For prices see below.

\section{Reid's Thoroughbred Yellow Dent}

See illustration to the left, from our own photo.)

If any seed grain can truly be called pedigreed, the Reid's Yellow Dent Field Corn. is certainly entitled to be known as such, as its history dates many years back. It he hith painstaking care to what is at the present time one of the best larieties of size, remarkably uniform, and one of bright yellow color, with solid, deep grain and small red cob. Has flom 18 to 24 rows of liernels on the cob, 50 to 60 grains in the row and is well flled over the ends, and especially the butt, a great favorite with huskers. Best of any by action report of 1901 gave the Reid's Yellow Dent an average of 100 bushels per acre, while the Agricultural Students' Union of per cent above all other varieties. Prices, Shelled-Large Pkt., 10c.; $1 \mathrm{~b}$. $25 \mathrm{c} . ; 2$ lbs., 40c., postpaid. By expres. lbs., $\$ 1.10 ; 56$ lbs., $\$ 4.00 ; 100$ lbs., \$7.00;

\section{Fodder and Ensilage Corn Varieties}

Red-Cob Insilage Corn

A Southern type of large, white corn, with strong, leafy stalks and short joints. Farmers growing the Red-Cob Hnsilage for the first time tell us they mous yield of fodder. Price, 14 lbs. $\$ 1.00$; 56 lbs., $\$ 3.75$; $100 \mathrm{lbs}$., $\$ 6.60$.

\section{Popping Corn}

Iivingston's Tom Thumb or Japanese Fulless

A new dwarf growing Pop Corn, heavy yielder, attractive ears peculiar in form. For full description and il$10 \mathrm{c}$; $1 / 2$ lb., $20 \mathrm{c} .2^{2}$ lbs., $50 \mathrm{c}$., postpaid. By express or freight, not prepaid: 5

\section{Queens Golden}

grow six or more feet high With large ears produced in abundance. Pops perfectly, is a favorite with many for feeding small chicks. Prices, Pkt., postpaid . 20 c.; 1 b., $25 \mathrm{c}$; 2 lbs., 40 c., prepaid: 5 1bs., 85c.; 25 lbs., \$3.75.

\section{Selected White Rice}

Our stock of this variety is ehoice, having been selected very carefully for many years. Very productive, excellent quality; very crisp and delicious. 2 los., 40c., postpaid. By express or freight, not prepaid: 5 lbs., $85 \mathrm{c}$; 25 Al Prices Subject to Market Change,

\section{西}

.
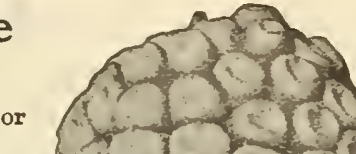

\section{.

$$
\sum_{5}^{2}
$$
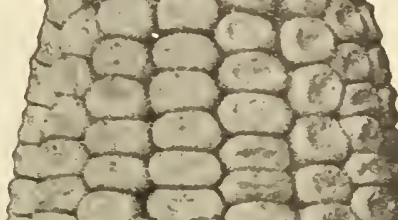

\section{西}
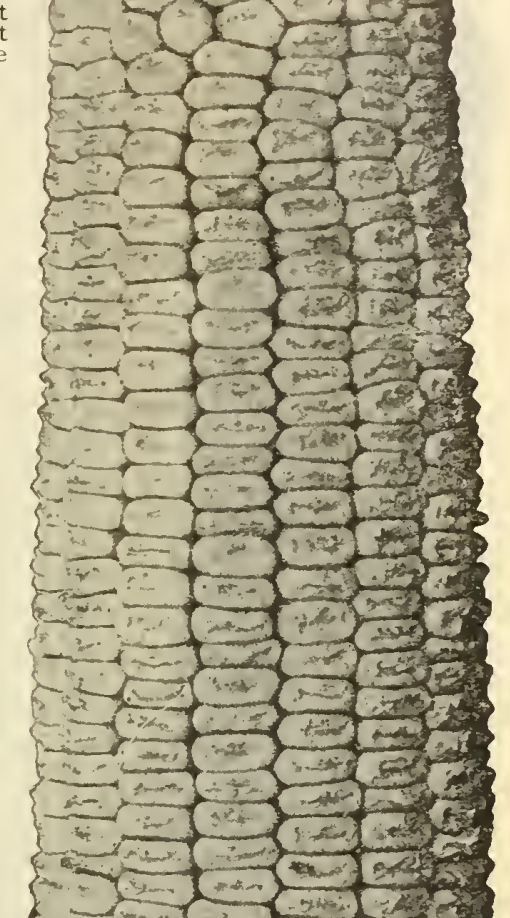


\section{Miscellaneous Farm Seeds}

Our grades of Farm Seeds are away above the average quality, and this makes a big difference in the value-the low, trashy grades being costly at any price-and yet our prices will be found very little, if any, above those quoted by others. The man in charge of this department, having been with us more than thirty years, is thoroughly posted and will take pleasure in giving customers any information desired. The prices quoted below are Net Cash, free on cars, this city, purchaser paying all transportation charges, except when quoted postpaid. At the prices given here we make no charges for bags or cartage. The prices quoted are subject to market fluctuations. Should any article seem, high, or when customers are in need of large quantities, we will be pleased to submit samples and quote, on application, the lowest price that the market will justify at the time. Please state quantities when writing for prices.

Frices on Farm Seeds are subject to important market changes. Ask for Samples and Frices before placing your order.

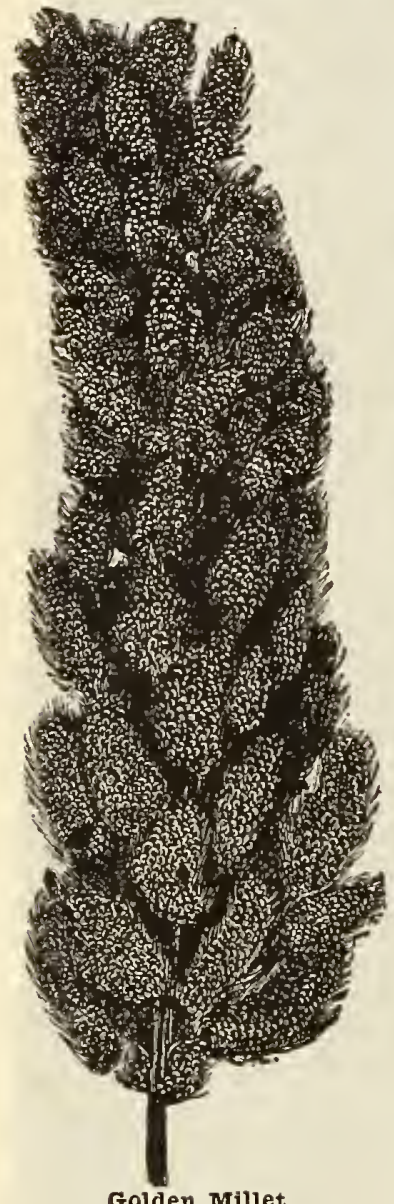

Golden Millet

\section{Millet (Golden)}

True Southern cultivated Tennessee grown stock is far superior to Western grown stock; will grow in any climate or soil, and where conditions are favorable its yield is very heavy; often from two to seven tons per acre of most nutritious feed. It is of special importance, however, to secure the true Southern grown stock.

True Southern grown produces a heavy and luxuriant growth, has very large heads which ripen evenly, and if cut while in bloom or before seed ripens it is quickly produced, cheap and valuable food, that is eaten readily by all our farm animals.

Have the land well plowed and thoroughly pulverized before sowing. Sow for hay not less than $50 \mathrm{lbs}$. per acre at any time between May 1st and July 1st. If sown broadcast cover with single stroke of harrow or light board drag, or it may be sown with a grain drill set to sow one bushel per acre, having the hoes hooked up so as not to cover seed over one inch deep. We prefer putting seed in with a drill. (Bu., 50 lbs.) Write for price in larger lots.

Large Pkt., 10c.; 1b., 20c. postpaid. By freight or express, not prepaid: 10 lbs. $\$ 1.00 ; 50$ lbs., $\$ 4.75 ; 100$ lbs. $\$ 8.75$.

\section{Hungarian Millet (Grass)}

For good, low ground or rich high land, Hungarian becomes even more valuable than German Millet. It is one of the earliest annual hay crops and can be sown later than any of the Millets. Is often sown as a catch crop after early Potatoes or other early maturing crops.

Hungarian is not so large and coarse as Golden Millet. It is very leafy and much finer in the straw, and if cut for hay before seed is ripe enough to grow or just as it goes out of bloom it is considered nearly equal to Timothy, and under favorable conditions should yield from two to four tons per acre of good, nutritious hay that is relished by dairy cows, young cattle or horses.

Hungarian Grass is generally looked upon as being much better feed for horses than Millet.

Sow from May 15th to July 15 th on well prepared soil at a rate of three pecks to one bushel per acre. (Bu. 50
lbs.)

Large Pkt., 10c.; 1b., 20c., postpaid. By freight or express, not prepaid: 10 lbs., $\$ 1.00 ; 50$ lbs., $\$ 4.50 ; 100$ lbs.,

Write for prices In large lotg on all Millets.

\section{Cow, or Southern Peas}

There is 110 surer or cheaper means of improving and increasing the productiveness of soils than by sowing Cow Peas. They put plenty of nitrogenous vegetable matter into the soil at a small cost. For hay they are most valuable. For ensilage they are unsurpassed. When it is desired to turn the entire crop under as a soil improver it is better to do so after the vines are partly dead. A good picking of the dried peas can be made before plowing under. Cow Peas can be sowed in May or June, after the ground is warm, or about the close of the corn planting. at a rate of one-half to one bushel per acre. $(60 \mathrm{lbs}$. to bushel.)

\section{Whip-Poor-Will}

An early bunch-growing variety; a great favorite in the North and West; is quite prolific. Write for price.

Black-Is quick to mature. Well adapted for Northern sections. A vigorous grower and a great yielder. Write for price:

Black-eye-A prolific vine-growing variety of merit: seed of ten sold for table use. Write for price.

Market Price on Cow Peas changes often. Write for prices on larger quantities when ready to buy.

NOTICE-Owing to going to press earlier than usual and crop not harvested, it is impossible to name prices on Soy Beans and Cow Peas. Kindly write for prices on Soy Beans

\section{Sunflower}

Mammoth Rus8 ia $\mathbf{n}$ - Immense yielder-125 bushels of seed to the acre has been grown at less expense than corn. Very highly rec$\mathrm{mm}$ ended for poultry. Best eggproducing food known. Good feed for horses as well (See illustration.) Choice Stock $10 \mathrm{c} .{ }^{2}, 1$, $1 \mathrm{~b} ., 25 \mathrm{c}$., $10 \mathrm{c}$; 1 p a $1 \mathrm{~d}$." $25 \mathrm{c}$, freight or express: freight or express: lbs., $\$ 4.00 ; 100$ lbs. $\$ 15.00$.

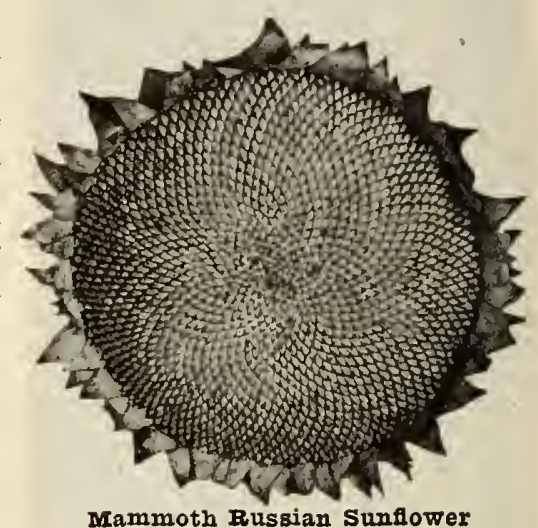

\section{Buckwheat}

Should be sown about the middle of June, using from 1 to 3 pecks of seed per acre. (50 lbs. to bushel.)

New Japanese-This new sort has proven to be much earlier and more productive than any other variety. Grains very large and of rich brown color. It excels all in yield and earliness. $1 \mathrm{lb}$., $25 \mathrm{c}$., postpaid. By express or freight, not prepaid: $10 \mathrm{lbs},, 85 \mathrm{c}$.; $50 \mathrm{lbs}$., $\$ 3.25 ; 100 \mathrm{lbs}$., $\$ 6.00$.

Silver Hull-A very good and popular variety. The grain is of light gray color, rounder than the common variety: has a much thinner hull. 1 lb., $25 \mathrm{c}$., postpaid. By express or freight, not prepaid: 10 lbs., $90 \mathrm{c}$.; 50 lbs., $\$ 3.50$; 100 lbs., $\$ 6.25$.

\section{All Prices Subject to Market Changes}

Mrs. T. Wolford Incas Co Ohio, writes as follows: "You. Hil find a small order for this year. We liked every "You will find a small order for this year. We liked every fine; had wonderful Potatoes. The Banner and Seneca Beauty were best. It was very drv with us." 


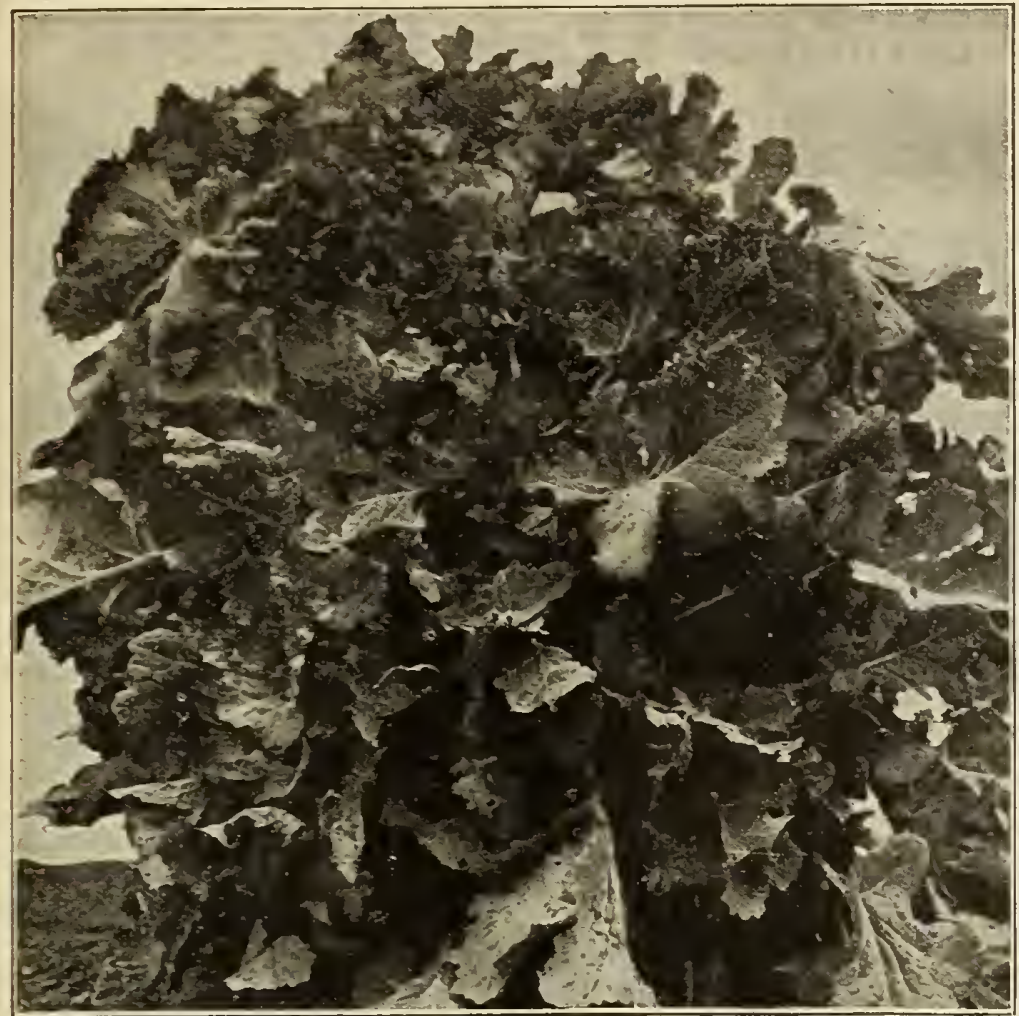

\section{Dwarf Essex Rape}

Best Quick-Growing Pasture for Sheep and Hogs

There is but one variety of Rape that has proven profitable in the United States, and that is the Dwarf Essex. No other plant known that will give so much pasUnder favorable conditions it Under favorable conditions it is ready for pasture in six weeks from time of sowing September at the rate of 3 to 5 lbs. per acre. Land should be prepared same as green mips. It is grown for pasture and have free access to salt. One acre of good Rape will furnish food for a flock of twelve sheep for 45 to 60 days. Our stock is the True Dwarf Essex, and not the worthless annual. Weight per bushel, 50 lbs. Price-Packet, 5c.; $1 \mathrm{lb}$., 35c., postpaid. By express or freight, 10 lbs., $\$ 2.20$ $\$ 19.00$. Write for prices on larger lots.

\section{Broom Corn}

Improved Evergreen-The best variety for general cultivation on account of the color and quaTity of brush. Ripens early, grows about 8 to 10 feet high; brush of good length, fine and straight, and always of green appearance when ripe. Our stock is select, having been saved by professional growers for their own planting. (46 lbs. to bushel.) $1 / 4$ lb., $15 \mathrm{c}$. $1 \mathrm{~b} . \mathrm{l}^{3} \mathrm{3} \mathrm{c}$.. $\$ 1.60 ; 25$ bs., $\$ 3.50 ; 100$ lbs., $\$ 12.00$.

Iowest market prices on large or small quantities will be given on application as long as stocks last.

All prices subject to market change.

Plant of Rape

\section{Soy Beans}

The Soy Beans have attracted much attention in recent years on account of their great value as a food, being much richer in protein than flaxseed, oilmeal, bran or oats, and can be used to balance a feed ration to good advantage; are used extensively in silage with corn, cane, etc. By its use dairymen can make a combination that is wholesome, economical and a completely balanced food for milch cows. They also equal or surpass clover as a soil enricher, gathering nitrogen from the air; are used by fruit men as a cover crop with good results. Mlay be used for silage or feed in matured state.

\section{Medium Early Green or Guelph Soy Bean}

One of the oldest and best known sorts, which has become quite a favorite north of the Ohio river both for seed and forage crop. Grows 24 to 28 inches high; stems medium stout, $1 / 4$ to $3 / 8$ inch in diameter, branches of ten filling the space between $3-$ foo rows. The leares very dark green, large and full in center, while long. Color of seeds, bright green.

Write for price.

Ito San-This is one of the best for northern part of the state; it grows erect from 25 to 30 inches tall, branches are fine; leaves, medium size; seeds medium sized, straw colored, orbicular in shape, distinguished by a brown spot beside the hilum or point f attachment to the pod. Matures in 100 to 115 days.

Write for price.

Ebong-Plant slender, not upright. much branched, leafy. Height, 30 to 40 inches. Ripe about September 15 th. Seeds rather small, flat and black. A good hay bean; not desirable for seed.

Write for price,

Mammoth Yellow-Latest maturing variety. Plants rather coarse, height 3 to $5 \mathrm{ft}$, ripens in 130 to 150 days. Good yielder, excellent to plow under as green manure and ensilage.

Write for price.

Ohio Grown Stock-To be sown north of the Ohio River. Price same as Eariy Green. (60 lbs. per bushel.)

NOTICE-Owing to going to press earler than usual and crop not harvested, it is impossible to name price on soy Beans and Cow Peas. Kindly write for prices before ordering.

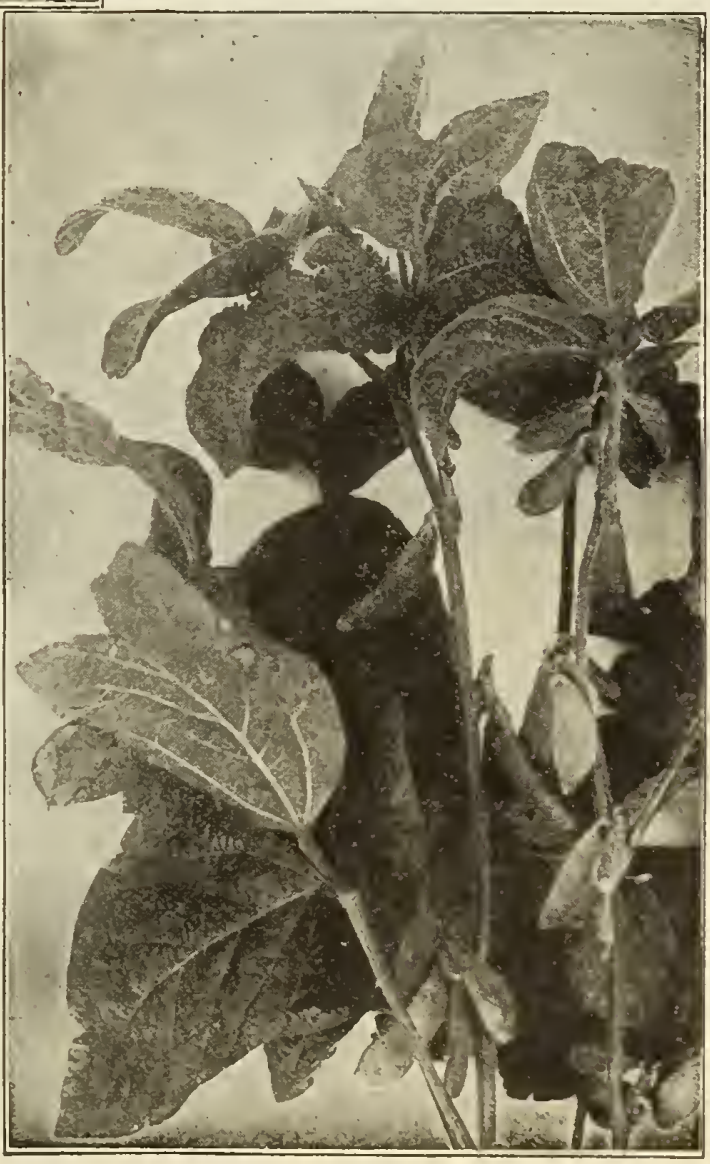

Soy Bean Plant 


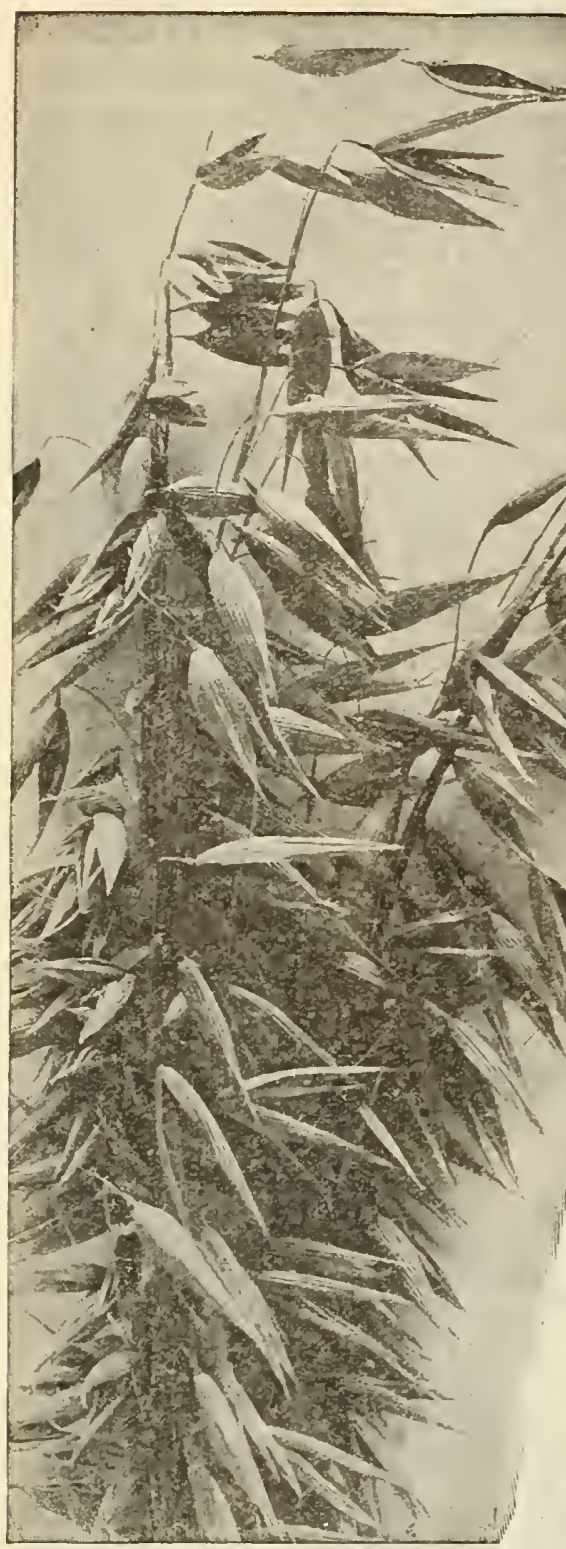

\section{Livingston's Finest Grain Seeds}

\section{Selected Seed Oats}

We have always realized the importance of supplying growers with the best selected Seed Oats, and we can truly say that our efforts in this direction have resulted in our customers obtaining increased yields by sowing our superior stocks and strongly advise that those customers who wish to secure the best yields use our northern grown years of ex growers leaves

Prices subject to market fluctuations.

Items on this page are shipped at buyer's expense except as noted.

\section{Regenerated Selected Swedish Oats}

(See illustration)-Originated and introduced by Garden Seed $\mathrm{Co}$ of England, are now well acclimated and have given excellent satisfaction. Weighs from 32 to 40 lbs. per measured bushel. The straw is heavy and strong and not liable to lodge. Heads are large upright and bushy Grains are white, large, thick and plump, and bushy desirable for feeding. Their strong root development enables them to withstand drought better than many varieties; ale quite early and less liable to damage by rust than many sorts.

Price-Lb, 20c., postnaid. By freight or express, not prepaid: 10 Ibs., 60c.; 50 lbs., $\$ 2.65 ; 100$ lbs., $\$ 4.50$. Bags free.

\section{Silver Mine Oats}

This Oat has reputation of long standing and is noted for its heavy and reliable yielding properties. It is very hardy and produce beautiful white kernels very desirable for the manufacture of rolled oats. The heads are large and sprangled and borne low down on the stalk, which is stiff, bright and clean, and seems to prevent lodging. We have handled this very reliable Oat for a number of years. Many farmers will sow no other sort, as they offer all the desirable points namely. Large, pluinp, white grain, good straw, medium early and good vielder. Price-Lb., 20c., postpaid. By freight or express, not prepaid: 10 lbs.. 60 c.; 50 lbs., $\$ 2.65 ; 100$ lbs., $\$ 4.50$. Bags free.

\section{New Victory Oats}

Is an Oat introduced from sweden and grown by us on our kirkersan and are much pleased with them. and offer them to our customers with full confidence that they will give satisfaction.
The head is large, well spread and filled with large, plump, rather barley-shaped, white grain. Straw is quite stiff and of good length. Stools freely, especially when sown thinly. This Oat being of new blood thinly. This a oat-growing country leads us to predict for them a successful future. 50 lbs., $\$ 3.00 ; 100$ lbs.. $\$ 4.50$. Bags free.

\section{Spring Wheat}

Marquis (New)-Is similar to Red Fife; quite early; beardless: yellow chaff, very plump, flinty kernel; said to be one of the best. Lb., 25c., postpaid. By express or freight: 10 lbs., $90 c$ : 50 lbs.. $\$ 3.50: 100$ lbs., $\$ 6.50$. and well filled: stools freely; kernels very hard. Lb., 25 c., postpaid. By express or freight: $10 \mathrm{lbs}$., $90 \mathrm{c}$; ; $50 \mathrm{lbs}$., $\$ 3.50 ; 100 \mathrm{lbs} ., \$ 6.50$.

\section{Barley}

The Best Nurse Crop for Sowing with Alfalfa

Beardlegs a Beardess-Barley needs a rich land, more sandy and lighter than that than any other grain. It should be cut before fully ripe (unless intended for seed), as it is then of better quality and less liable to shell. Use about 100 lbs. per acre. Lb., 20c., postpaid. By freight or express: 10 lbs., 75c.; 50 lbs., $\$ 3.00 ; 100$ lbs., $\$ 5.75$.

\section{Spelz or Emmer}

A valuable rgain recently introduced from Russia. It is adapted to dry sections and poor soil, often yielding 50 bushels or more of grain per acre. The straw and grain of Speltz have feeding value equal to barley and are relished by all kinds of stock. Sow in the Spiring, 50 lbs. per acre. Large Pkt., 10c.: Lb.. 20c., postpaid. By freight or express: 10 lbs., 75c.; 50 lbs.,

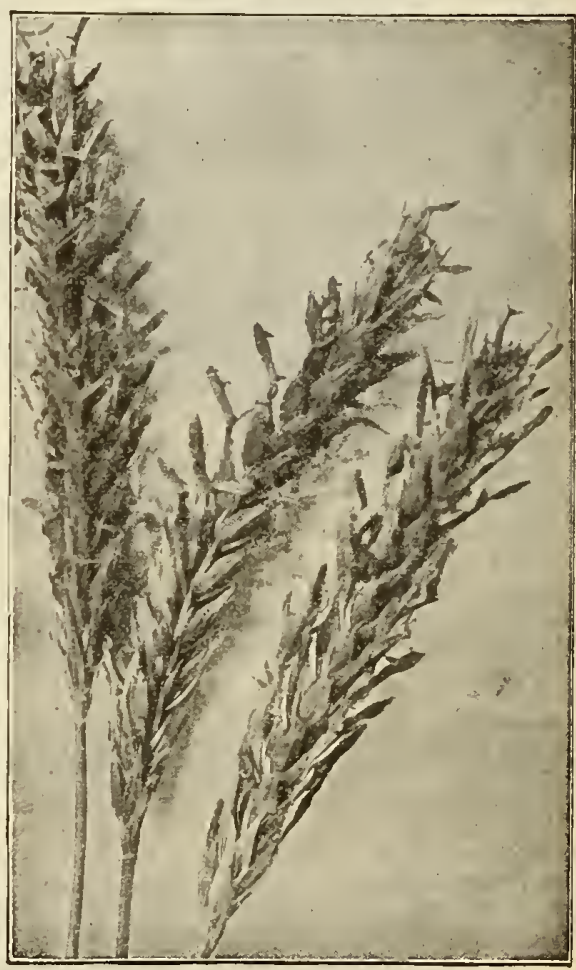

Beardloss Barley 


\section{Various Types of Sorghum, The Great Dry Land Forage Plants}

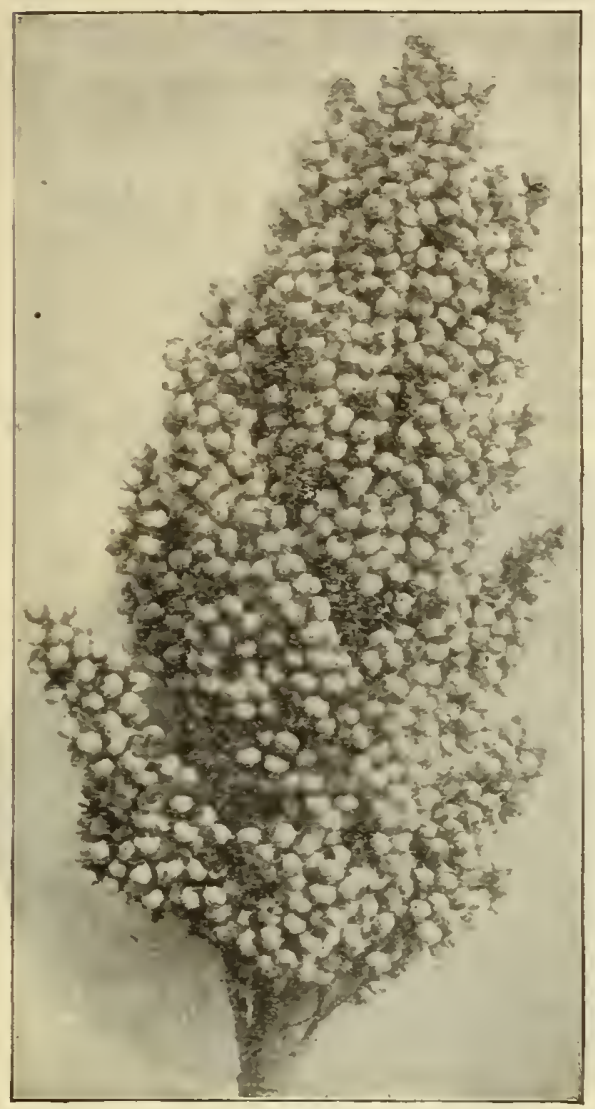

Feterita

Feterita

An Extra-Early Strain of White Kaffr Corn

Introduced 1912 , has again proved its worth planted on both muck and upland on nur own farms, and recommend it with full confidence to all Poultry men and for use wherever Kaffir Corn can be used It is twenty to thirty days earlier than Kaffir Corn, heads equally as large, withstands drought as well or better. One seed produces anywhere from 3 to 10 stalks, each bearing a full-sized head, all stalks are well covered with large blades from the ground up and after the heads are removed there is from two-thirds to three-fourths as much stover left as would be furnished by any average crop of corn. Seed planted after April $16 \mathrm{th}$ ripe and harvested on our lands Sept. 21 st. It is one of the surest croppers and one of the best foods for poultry and pigions. Owing to its earliness the best of its class for latitudes south of Chicago.

Prices-Pkt., 5c.; 1 lb., 20c., postpaid; freight or express, not prepaid: 10 lbs.

\section{Canada Field Peas}

Every year there is more inquiry for Field Peas. They stand in the front rank as a fodder, especially for hogs. They can be fed green or dry. They will grow on land that will not produce clover. Sow oats, sow 1 bushel of each. Sow the peas first and plow under 4 or 5 inches; then oats on top and harrow in. Price-By freight or express, not prepaid: 15 lbs., larger quantities, write for prices, stating quantity you can use.

\section{Peanuts}

\section{Improved Large Virginia}

A very profitable variety to grow and is easily cultivated, very erect; the largest pods and kernels with fewcr imperfect pods than any variety: The vines make valuable forage for stock. (Bu. 22 lbs.) By mail, large Pkt., $10 \mathrm{c}$; 1/4 1b., $15 \mathrm{c}$, postpaid; by freight or express: 5 lbs., $\$ 1.25 ; 10$ lbs., $\$ 2.00$.

\section{Sweet Spanish Peanut}

The earliest variety grown. Pods are small, remarkably solid, Well filled, and of an extra fine quality is leld per acre very large. Large express: 5 lbs., $\$ 1.25 ; 10$ lbs., $\$ 2.00$.

\section{Kaffir Corn}

A Great Fodder Crop. The Finest Grain for Poultry and Pigeons

50 lbs to bushel) Feten by all domestic animals. whether fed in the grain or ground and cooked. For grain sow at rate of 5 to 1bs. per acre, and cultivate the same as corn. Average yield, 50 bushels per acre. For hay, lbs. per acre, and cut when seed is coming to , dough stage. Makes valuable hay. rielding from to 10 tons per acre. Oz., $5 \mathrm{c}$.; 1 lb., 20c. postpaid.

\section{Sorghum or Sugar Cane}

For Fodder-Sow first to 15 th of June, 100

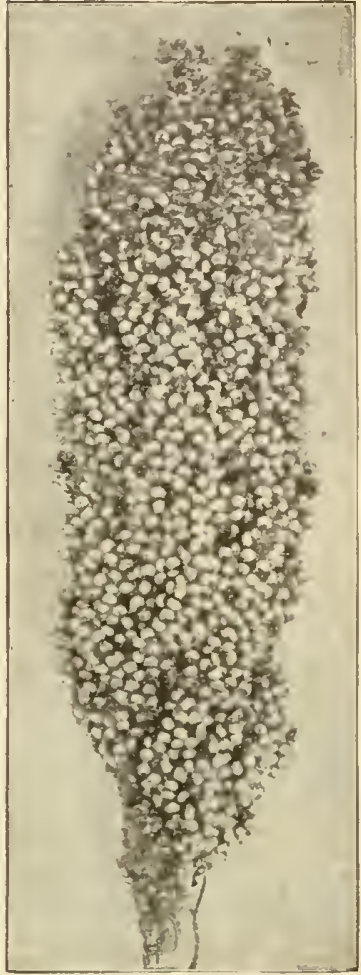

Kaffir Corn bs seed per acre, and harrow to cover 1 to 2 inches. Harvest after first frost. Cut with self-binder or mower, and after three dav's of sun put up in large cocks and feed from field or store in long, 8-foot wide ricks near feed lot. Yield, 8 to 10 tons per acre. Cows and all stock do as well when fed on it as on grass.

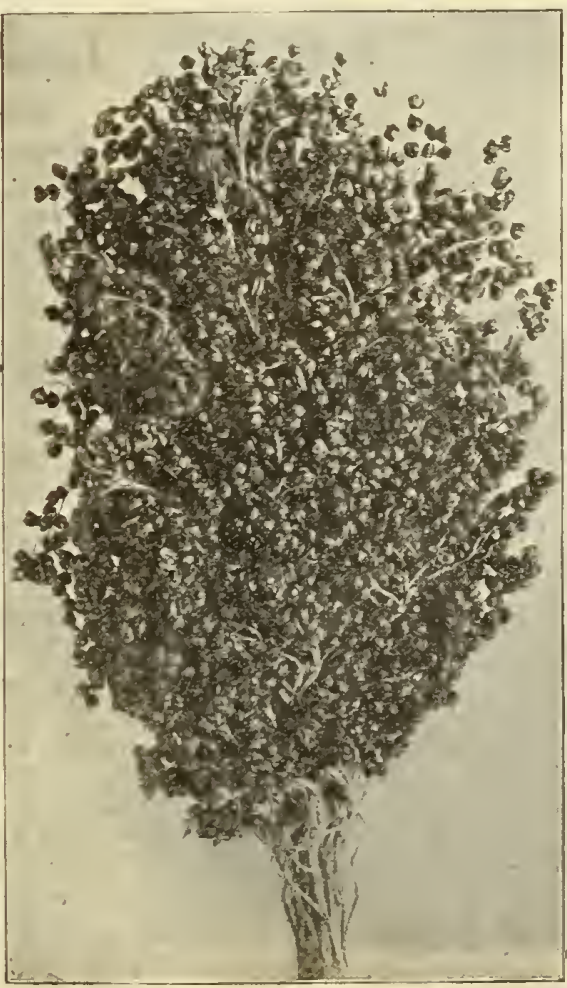

Sorghum or Sugar Cane
For syrup, plant in hills and

Early Amber Cane-The earliest and makes the finest guality of forage or syrup. Oz. c., 1 lbs., 20c., postpaid. By reight ol" express, not prepaid lbs., $\$ 5.25$.

Early Orange Cane-A strong grower stalks heavier and a little later than Amber. Oz. freight or express, not prepaid: 10 lbs., 70c.; 50 lbs., $\$ 2.75 ; 100$ lbs., $\$ 5.25$.

Write for prices on larger quantities, stating amount you can use. Will send samples gladly if you so desire.

Items on this page are sent at buyer's expense except as noted.

Owing to frequent change in price of items on this page, kindly ask for price on larger quantities than here quoted.

All Prices Subject to Market Changes

W. C. Clou, Tuscarawas County, writes: "I have used your seeds for over 20 years and always found them very satisfactory." 


\section{Patatatas Livingston's Superior Seed Potatoes rartorealn}

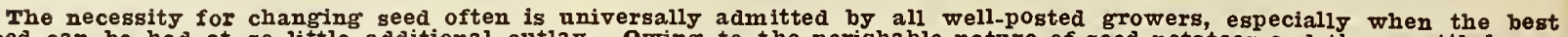

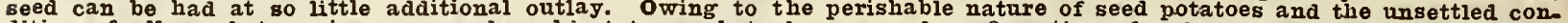
dition of all markets, prices are made subject to market changes and confirmation of order on receipt of same.

\section{Special Instructions}

Owing to the perishable nature of seed potatoes and the unsettled condition of markets, all prices are made subject to market changes and confirmation of order on receipt of same, and will fill orders just as soon as the weather, in our judgment, will permit. However, we cannot become responsible for changes in the weather by which the potatoes might be damaged while en route. We will ship at any date our customers may designate, when requested to do so, regardless of the weather, if customers wish to take their own risk. When ordering late, please state whether we shall return the money or send some other kind of equal value, provided we cannot supply the sort ordered. Please give plain and explicit shipping direc-

Order Seed Potatoes Eariy. We would most earnestly request our customers to send in their orders early. We then book and fill them in the order received. By so doing you take very little risk in getting what you want, as compared with waiting until the last moment.

\section{Seed Potatoes by Express or Freight}

By the $100 \mathrm{lbs}$, or fractional part prices, buyers pay the freight or express charges. No charges for bags.

\section{Seed Potatoes by Mail}

Prices for small quantities of any of our Seed Potatoes, unless otherwise quoted: Lb., $25 \mathrm{c}$., postpaid.

All transportation charges must be paid by the bryer, C. 0 . D.

\section{Extra Early Ohio Potato}

Some early varieties will yield edible potatoes about as soon as the Extra-Early Ohio but their tops will be green for days after the Extra-Early Ohio have fully ripened. The Extra-Early Ohio is fully two weeks ahead of the Early Rose, and is a general favorite with potato growers and marketmen alike. The sprouts are very strong, the vines grow erect and are easy to cultivate. Maturing early, it brings for Potatoes. The tubers grow compact in the for Potatoes. The tubers grow compact in the nearly every Potato is of marketable size; has few eyes, which are even with the surface. With heavy manuring, close planting and good culture, a very large and profitable crop can be expectedPrices-Choice Northern Grown Seed: 10 lbs. $\$ 1.00 ; 25$ lbs., $\$ 1.75 ; 50$ lbs., $\$ 3.00 ; 100$ ibs., $\$ 5.50$. Special prices will be quoted on larger quantities.

\section{The Seneca Beauty Potato}

Very Smooth, Uniform Size, Almost Blight-Proof, Productive, Splendid Quality, Fine Keeper

A grand, good, medium-late Potato, and too much has not been said in its praise. Its beautiful and distinct appearance sells it in any market and its fine table qualities please all. The tubers are large and smooth, with few eyes close to the surface, and of a beautiful pink color. Uniform in size and shape, scarcely any small ones. Vines rank and healthy, and loaded with beautiful blossoms. Good keeper and a heavy cropper. Prices-Choice Sorted Northern Grown Stock: 10 lbs., 75c; 25 lbs., \$1.50; 50 lbs., $\$ 2.80 ; 100$ lbs., $\$ 5.25$.

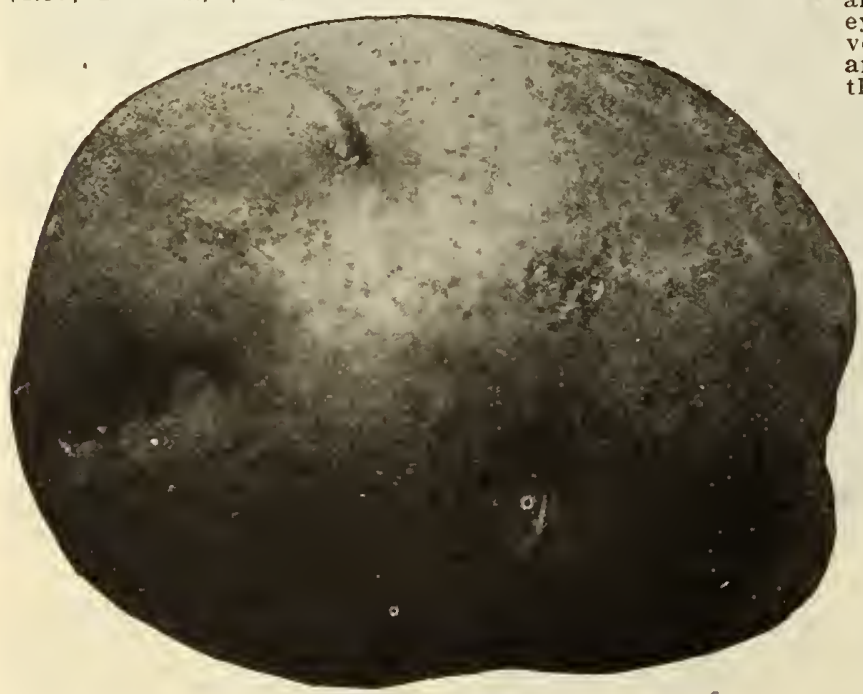

Extra-Early Cobbler

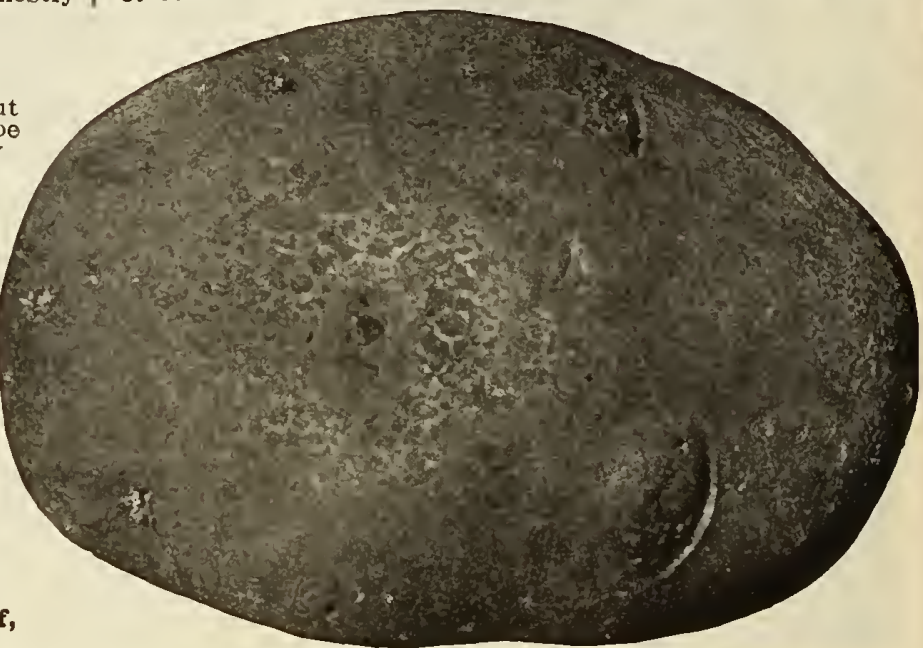

rivingston Banner

\section{Livingston's Banner Potato The Best Main Crop Variety}

The Banner is a seedling and is one of the finest main crop white Potatoes on the market. No Potato ever made so good a record in so short a time with all classes of growers and on all kinds of soils. None surpass it in unirorm, handsome appearance. Its slightly rusty skin is of a light, cream-white color. Its shape is a little oblong and slightly flattened (cooking through easily). The eyes are very shallow. The size is ourge and desirable very few being under marketable size. Always smooth and regular in form; grows strong and vigorous from the very sprout. Is also a great drought resister. As near blight and scab proof as any variety we have ever known. The flesh is very white and whether boiled or baked is of the same delicious tasty quality. Medium late. Choice Sorted Northern Grown Stock. Prices: 10 lbs., 75 c.; 25 lbs., $\$ 1.50 ; 50$ lbs., $\$ 2.80 ; 100$ ibs., $\$ 5.25$. Write for special prices in large quantities.

\section{Extra Early Cobbler (Irish Cobbler)}

One of the most reliable first-early Potatoes ever sent out. It ripens almost with the Early onio and is so uniform that every hill seems to ripen at one time. The yield is very large for an early variety-equal to some of the late ones. Form, oval and round; skin lightly netted, creamy white and having few eyes, which are quite shallow-some even with the surface Flesh pure white and of the finest quality-not exceered bv any earlv variety. Keens perfect untli Spring, when it starts large, strong and vigorous sprouts. Its strong growth, earliness, uniformity, large yield, fine quality and very handsome appearance have brought the Extra-Early Cobbler right to the front as a profitable variety for home or market use.

Prices-Choice Sorted Northern Grown Stock: 10 lbs., $\$ 1.00 ; 25$ lbs., $\$ 1.75 ; 50$ lbs., $\$ 3.00 ; 100$ lbs., $\$ 5.50$. Aul Prices Subject to Market Changes.

Clifford Funderburg of Indiana, writes on April 19th, 1918: "The potatoes reached me today. I have never seen finer seed." 


\section{The Flower Seed Department}

O

UR list of flower seeds will be found to contain all varieties of real merit. Many times varietles are listed which are of no value whatever in the garden or are so difficult to grow that unless one has every facility for propaga. tion, disappointment is sure to follow the purchase of seed. We want our seeds to glve satisfatcion and prefer not to have a very extended list, rather than to cause disappointment in any of the varieties prucured. Cultural directions will be found on most of our seed packets. We will also give free to customers, on application, a very instructive and helpful leaflet-"Annuals from seeds."

Anntrals are those flowers that bloom and ripen their seed the first year, then die. Among these are Asters, Balsams; Mignonette, Sweet Peas, Nasturtiums, Morning Glories and many other very brilliant and fragrant sorts.

Biennials from seed, generally bloom the second year, then die. Some varieties, if planted early, bloom the first season; therefore are treated as Annuals.

Perennials are those that endure our Northern Winters with little or no protection and live and bloom several years in succession. A large majority of the Perennials will bloom the first year if started early in the Spring. Hollyhocks, Columbine, Larkspurs, Foxglove, Poppies, etc., are in this popular class.

Discounts on Packet Flower Seeds For 25 cents select 6 Five-cent, or 3 Ten-cent Pkts. For 50 cents select Dackets to the amount of 65 cents. For $\$ 1.00$ select Packets to the amor In PACKETS.

T. Collections of seeds in Packets cannot be included when taking advantage of these discounts.

\section{Asters}

The Aster is, perhaps, the most popular annual flower grown in this country, and justly so on account of its ease of culture, season of bloom and lasting qualities both in the garden and as a cut flower. Seed can be sown in the house in shallow boxes (cigar boxes are good), and in the hot bed in March or in cold frames the first of April and later (about May 1st) in the open ground. Transplant the smaller varieties about eight inches apart in the row and such varieties as Semple's Branching, fifteen inches apart, the rows to be twelve inches apart. The richer the ground the better your flowers will be and water is very necessary.

\section{American Beauty}

1399-A variety of recent introduction and one that promises to become one of the leading sorts. The plants are of very strong, vigorous growth, averaging from two to three feet in height. The flowers are of remarkable size, having the widest petals of any Aster. Type of flowers is similar to the Semples variety but the flowers are much larger and are produced on stiff stems of ten measuring more than two feet. The large flowers are bright carmine rose and are almost identical in color with the well-known American Beauty Rose. Pkt., 15c.; 2 Pkts., 25c.

\section{Lavender Rochester}

1495-The magnificent flowers are' more double and more Chrysanthemum-like than those of the original Lavender Pink Rochester. The long, narrow petals fall over one another in a charming cascade of color, forming a wonderful shaggy mass that cannot be equaled for richness of effect. In addition to their great diameter they have a most remarkable thickness, making them truly massive. Vick's Lavender Rochester is an exquisite shade of clear light lavender. Pkt., 10c.

\section{Autumn Glory}

1494 -Pure sea-shell pink. While similar in color to Semple's Pink, it has a better and more substantial flower, a deeper and longer keeping color, larger and stronger type of plant. Its most distinctive characteristic and chief claim for recognition, however, is the fact that it is later in season than any of the other varieties. The flowers are very double and are borne on stems of unusual length. Pkt., 10c.

\section{Shell Pink Rochester (See Illustration Alongside)}

1493-In this Aster we have another color added to the already popular Rochester type. The color as the name indicates, is of a soft shell-pink, one of the most popular colors in Asters. The flowers are large and are supported on long, stiff stems. The long, narrow petals are twisted and curied, making a very rich effect. Pkt., 10c.

\section{Sensation}

1398-This new sort is the darkest red of all Asters. The plant averages about 18 inches high and is of the true branching type. Stems are long and stiff, making it ideal for cutting. The flower is very double and averages about three inches in diameter. On account of the deep, velvety-red color of Sensation, it is exceptionally fine for either bedding or border. Pkt., 10c.

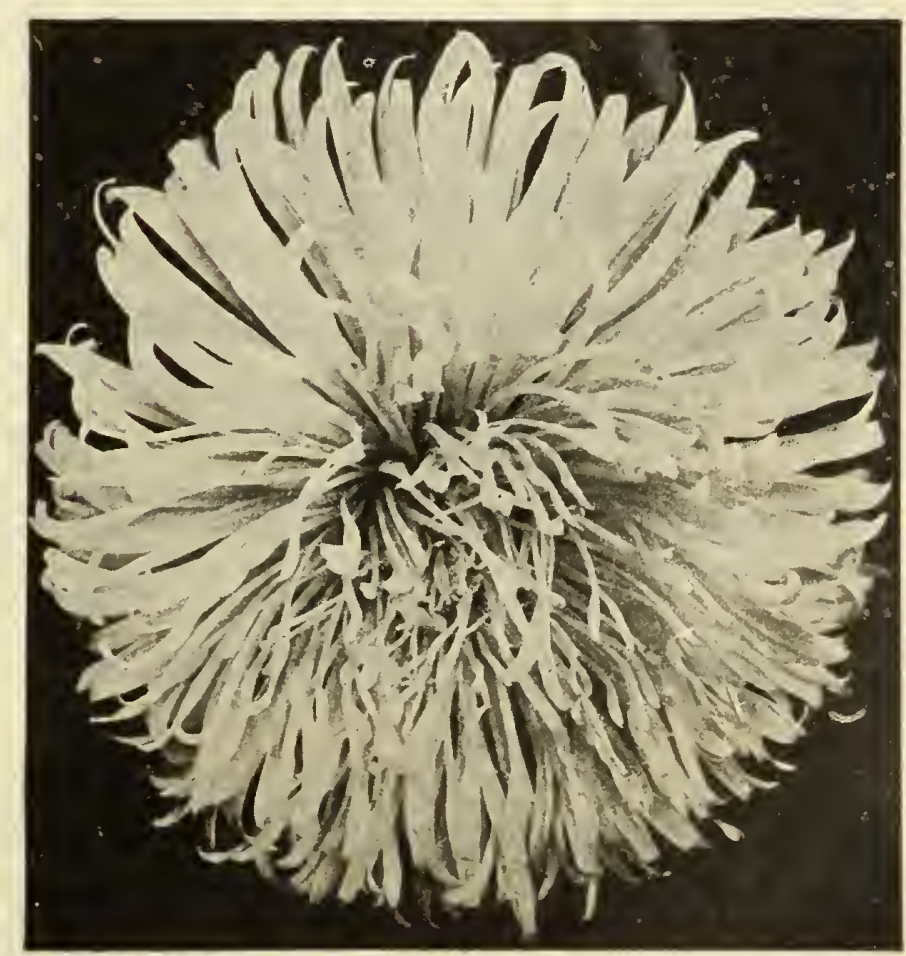

Shell-Pink Rochester Aster 


\section{Asters (Continued)}

\section{Semple's Giant Late Branching}

Without question, the finest Aster grown. It has size, vigor, fine stems, beauty of form and varied color to recommend it and, while not so early as many of the other varieties, it stands at the head of the list both for the home garden and as a florist's flower.

1400 Semple's Giant Finest Mixed Colors-All shades and colors. Pkt., 10c.; $1 / 4$ oz., 40c.

1401 Semple's Glant Iavender. Pkt., 10c.

1402 Semple's Giant Royal Purple. Pkt., 10c.

1403 Semple's Giant Pure White. Pkt., 10c.

1404 Semple's Giant Crimson. Pkt., 10c.

1405 Semple's Giant Shell Pink. Pkt., 10c. $40 c$.

Collection of Semple's Giant Asters, 5 above sorts,

\section{Mikado Pink}

In type Mikado Pink belongs to the Comet class. Petals are narrow, very long and gracefully reflexed. The outer petals show to their full cxtent, while gradually toward the center they bend and curl across each other, forming a perfectly double fower. 1381 -Pkt., $10 \mathrm{c}$

\section{Mikado White}

A magnificent new Aster, same as Mikado Pink, except in color, which is pure glistening white. except in color

\section{Pink Enchantress}

A new variety of upright growth. The flowers are very double and are produced on good stems. The color is of late branching and produces its flowers on long stems; is a mid-summer variety. 1492-Pkt., $10 \mathrm{c}$.

\section{Peerless Pink}

The introducers of this variety state that it is midway between Crego and the Late Branching varieties and of beautiful shade of pink. It blooms a little ahead of the Late Branching and produces its flowers on long stems. 1406-Per Pkt., 10c.

\section{Queen of the Market}

About two or three weeks earlier than most other Asters. They bloom profusely and are of graceful habit. Their shape is very similar to Semple's Giant Branching Aster. The perfect flowers are borne on long stems and in great variety of colors, making them extremely useful for cutting. A favorite sort. Height $1 \frac{1}{2}$ feet.

1440 Mixed Colors-All colors in finest mixture. Pkt. $10 \mathrm{c} . ; 1 / 4$ oz., $30 \mathrm{c}$

Separate Colors-1441 Scarlet, 1442 Pink, 1443 Crimson, 1444 Pure White, 1445 Dark Blue, and 1446 Iight BlueEach color, Pkt., $10 \mathrm{c}$. $50 \mathrm{c}$

Collection Queen of the Market Asters, 6 separate colors,

\section{Daybreak}

Flowers are very large and double, beautiful shell-pink color. A grand Aster for cutting purposes, growing 2 feet high. 1384-Pkt., 10c.; $1 / 4$ oz., $75 \mathrm{c}$.

\section{Snowdrift}

A white Aster of Comet type and one of the earliest of all. In bloom same time as Queen of the Market. 1485Pkt., 10c.

\section{Invincible}

A very popular Aster in many parts of the country. It is a mid-season variety, very similar in form to the late branching, but flowering a couple of weeks earlier. 1435 White, 1436 Light Rose, 1437 Iavender, 1438 Purple, 1439 crimson-Each $10 \mathrm{c}$. per pkt.; set of tive varieties, $40 \mathrm{c}$.

\section{Purity}

Double flowers of a glistening pure white; similar to Daybreak in form and habit. $1386-$ Pkt., $10 \mathrm{c}$; $1 / 4$ 0\%. $75 \mathrm{c}$.

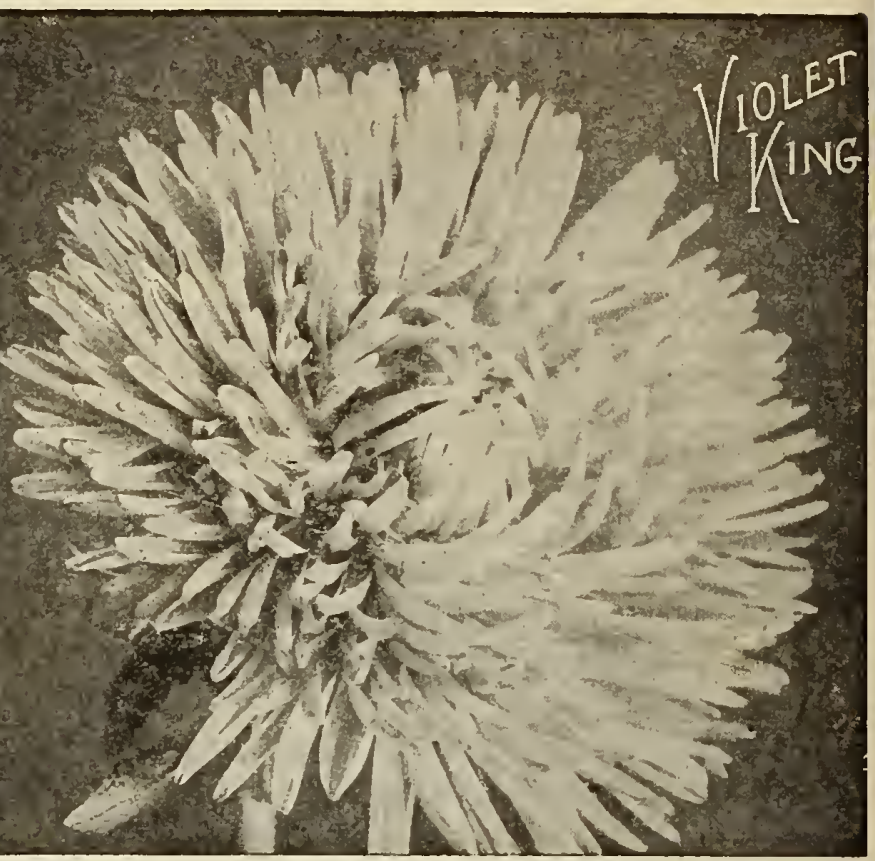

\section{Violet King}

The habit of growth of this Aster is similar to the Branching type, growing vigorously about $2 \frac{1 / 2}{2}$ feet high; has long stiff stems. In form the flower is entirely new and distinct from any other variety; round, full and very large, many of the flowers measuring from 4 to 5 inches in diameter. Petals somewhat resemble the quilled varieties, but are much longer and broader. 1380-Pkt., 10c.; $1 / 4$ oz., 75c.

\section{Crego Pink}

A large variety of a most beautiful shade of pink unlike any other Aster. It comcs into bloom just ahead of the late branching Asters and being of Comet type affords variety in the garden. 1409-Pkt., 10c.

1408 Crego white-Similar to above, only white. Pkt., $10 \mathrm{c}$.

1407 Crego Purple-A new color added to this popular type recently. Pkt., 10c.

\section{Vick's Early Blanching}

The habit of growth is identical with its parent, the Late Branching Asters. Plants branch freely, are vigorous in growth. They produce flowers on long, stiff stems and luxurious foliage. The shape of the flower is round, and the size extraordinary large. A very valuable flower for commercial growers and the home garden.

The new Aster comes in two dainty and desirable colors -pink and white. Our stock of seed is true and comes direct from the original producer. 1410 White, per pkt. 10c.; 1411 Pink, pkt., 10c.; 1412 White and Pink Mixed, pkt., $10 \mathrm{c}$.

\section{Giant Comet Asters}

An ideal class for cut flowers, being not only most profuse bloomers, but each individual flower is borne on a stiff stem and resembles an exquisitely curled and twisted Japanese Chrysanthemum. Height 2 to $2 \frac{1}{2}$ feet.

1430 Giant Comet Crimson, 1431 Giant'Comet Iight Blue, 1432 Giant Comet Rose Pink, 1433 Giant Comet Dark Blue, 1434 Giant Comet, the Bride, 1428 Giant Comet, Mixed Colors, 1429 Giant Comet Snow White at 10c. per pkt.

Collection Giant Comet Asters, 5 separate colors, 40c. 


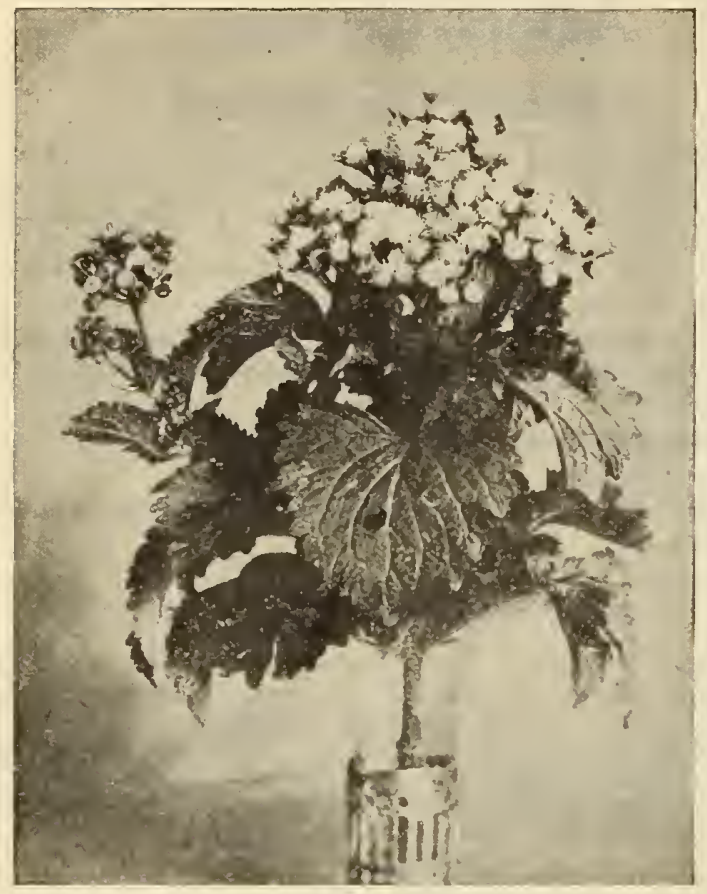

Ageratum Perfection Blue

\section{Ageratum (Floss Flower)}

Very showy plants: bloom profusely the whole summer: fine as cut flowers. Splendid for borders, ribbon beds, etc. Half-hardy annuals. (See illustration.) 1312 Perfection Blue-Splendid large heads of deep amethyst blue. Compact growth, 9 inches high. Deepest colored of all Ageratums. Fine border. Pkt., 10c.; 1/4 oz., 1314 Princess Victoria Iouise-A very pretty dwarf sort. Bushes 5 to 6 inches high. splendid combination with Sweet Alyssum. The color is a bright blue, with white enter. Pkt., 10c.; 1/4 0\%., 35c.

1316 Iitle Blue Star-Exceedingly dwarf, bushy growth not over 4 or 5 inches high. Densely covered with clusers of bright blue flowers. Very fine for edging. Pkt., 25c

1318 Imperial Dwarf Blue-s inches. Pkt., 5c.

1319 Imperial Dwarf white-8 inches. Pkt." 5c.

1320 Mexicanum-Lavender-blue-1 $1 / 2$ feet. Pkt., $5 \mathrm{c}$.

\section{Sweet Alyssum}

One of the sweet-scented flowers that should always be in every garden. An easily grown annual; fine for beds, edgings or for cutting. In bloom all summer and through the greater part of Fall.

1325 Sweet Alyssum (Maritimum)-One of the most popular of our hardy annuals, both for cutting and for edgings. The pure white flowers are noted for their exquisite fragrance. Blooms continually from earliest Summer until hard frosts. Pkt., 5c,; oz., $40 \mathrm{c}$

1327 Iittle Gem, or "Carpet of Snow"--A dwarf, very compact-growing variety, that, while only 6 inches in height, each plant will carpet a circle from 20 to 30 inches in diameter. From early Summer until very late futumn the plants are a solid mass of snow-white flowers of delicious fragrance. Pkt., 5c.; $1 / 4$ oz., $25 \mathrm{c}$.; oz., $75 \mathrm{c}$.

1329 Saxatile Compactum (Golden Saxatile, or "Basket of Gold")Fine for perennial variety; its howers are a most brilliant

\section{Amaranthus}

1333 Fine Mixed-Foliage brilliantly ornamental, producing a striking effect in the border as a background, or as a center of beds. Of the easiest culture. Annuals. Three feet. Pkt., $5 \mathrm{c}$; ; oz., $40 \mathrm{c}$.

\section{Asparagus}

1372 Plumosus Nanus (Climbing Lace Fern)-One of the prettiest house plants. Its foliage is indispensable for bouquets, and lasts a long time after cutting. Half hardy perennials. Pkt. (10 seeds), $15 \mathrm{c}$; 25 seeds, $30 \mathrm{c}$; 100 seeds, $\$ 1.00$.

1374 Sprengeri (Emerald Feather, or Abyssinian Parlor Fern)-This is one of the most beautiful plants for either pot culture or hanging baskets Useful for bouquets. Grows freely all the year; $a$, popuiar house plant Pkt., (15 seeds), $10 \mathrm{c}$.

\section{Giant-Flowered Antirrhinum \\ (Snap Dragon)}

he of the most beautiful and useful bor. Its very oraceful flowers are borne stems and in the greatest diversity of colors. The spikes to

Rose-Delicate Rose-Pink. Plit., 10c assort

Dwarf Mixture-Contains the very choicest colors. 1:

1306 Dwarf perennial plant, covered with pretty white flowers Arabis Alpina

\section{Asperula}

\section{Aquilegia or Columbine}

Exceedingly showy, early blooming, hardy plants; always fav. the graceful, long-spurred range of colors and shades has been largely increased. Hardy 1356 New Long-Spurred "Rose Queen"-A beautiful variety, producing in great profusion very graceful, large do 1365 Chrysantha-This beautiful variety is a clear yel. , being an unusual color in Columbines, and of the long. nearly all summer. One of the best and very hardy. 368 Coerulea-The true Rocky Mountain variety, a lorado. A splendid plant for the hardy border. Pkt., 10c Double Varieties Mised-A very choice assortment 1362 Single Varieties Mixed-All the best sorts and col-

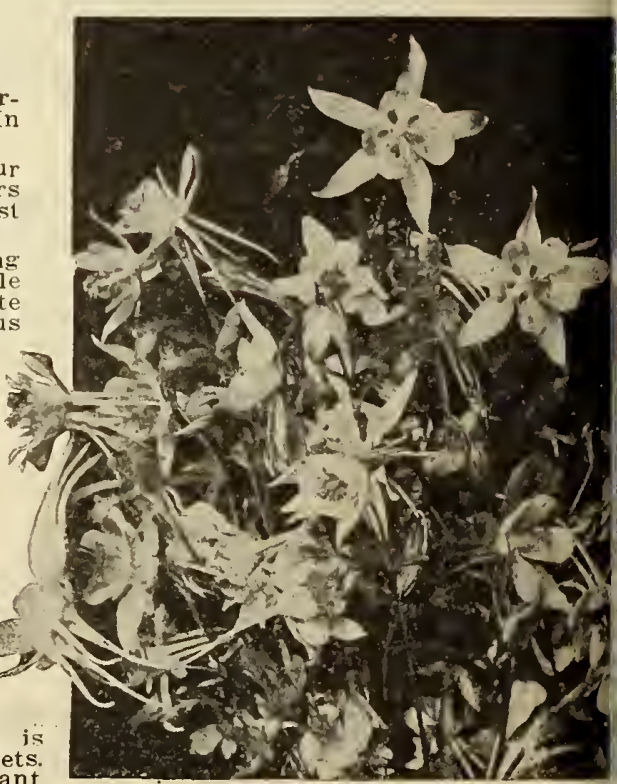

Aquilegia 


\section{Double Balsam}

1500 Iivingston's Premium Balsams, Finest Mixed-r) strain is unsurpassed. The large, double flowers are as tine as the most elegant Camellia. The size, fine form, varied and brilliant colors of our Premium Balsams are greatly admired. Pkt., $10 \mathrm{c}$; $1 / 4$ oz., $40 \mathrm{c}$.

1504. Double Camellia-Flowered, Finest Mixed-A very choice assortment of all the best varieties and colors in these favorite Balsams. Pkt., $5 \mathrm{c}$.; $1 / 40 \mathrm{Oz}, 25 \mathrm{c}$.

1515 Double Mcixed Balsams. Pht., 5c.; oz., 50c.

\section{Balsam Apple and Pear}

1518 Mormordica, Mixed-Tery curlous vine with ornamental foliage. Its large, golden-yellow fruit open. when ripe and shors its brilliant blood-red inside. Hardy annuals. 10 feet. Balsam Apple and Pear Mixed. Pkt., $5 \mathrm{c} . ; 1 / \mathrm{s}$ oz., $15 \mathrm{c}$

\section{Begonias}

1523 Finest Mixed-Our strain contains a great $\vee$ ariety of colors, both in flowers and foliage. A superior assortment. Pkt., 10c.

1524 Vernon-An elegant variety, with bright orangecarmine flowers and rery dark leaves. Start the seed early in the house or greenhous. Plit., 10 C.

1520 Tuberous Booted, Best Double Mixed-Prize strain Pkt., $25 \mathrm{c}$.

1521 Tuberous Rooted, Best Single Mixed-Prize Strain! Pkt., $25 \mathrm{c}$.

1522 Begonia Rez (Ornamental-leaved Varieties) - A collecton of house plants $w$ ithout some of these elegant plants seems incomplete. The leathery leaves are bronze, red, silver and gold. Finest sorts. Pkt., 25c

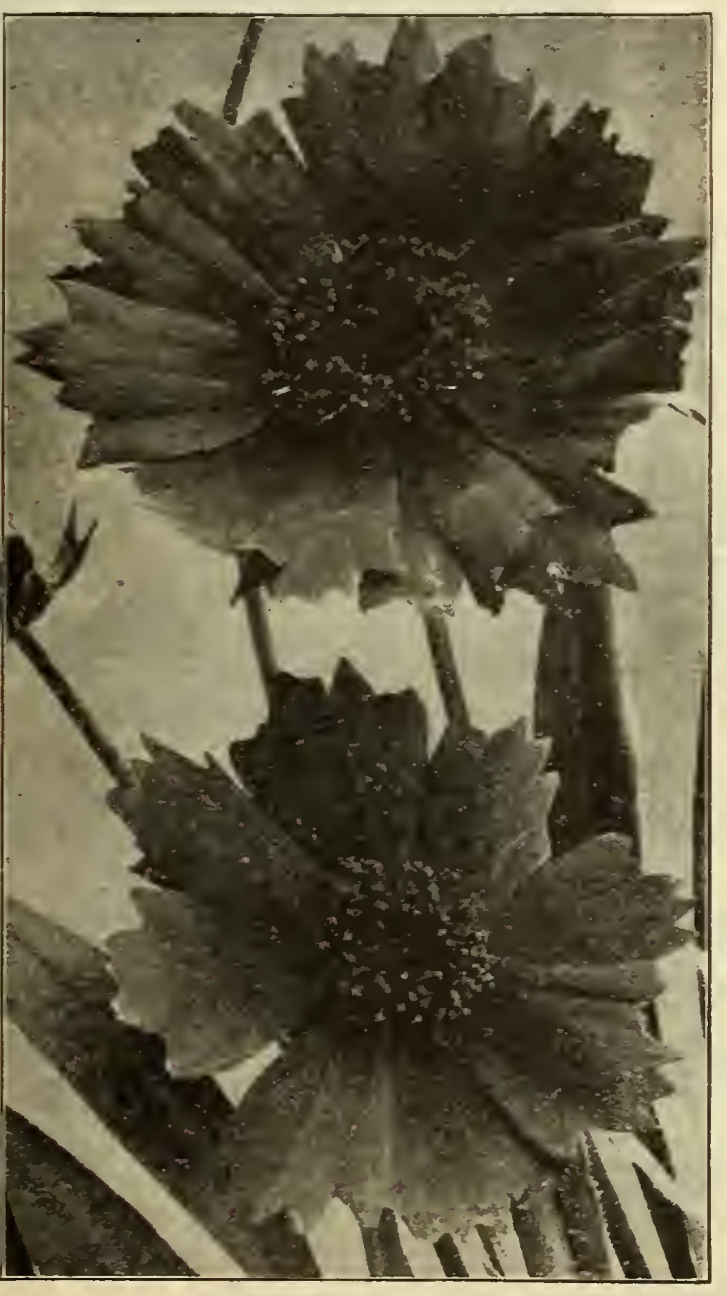

Calliopsis

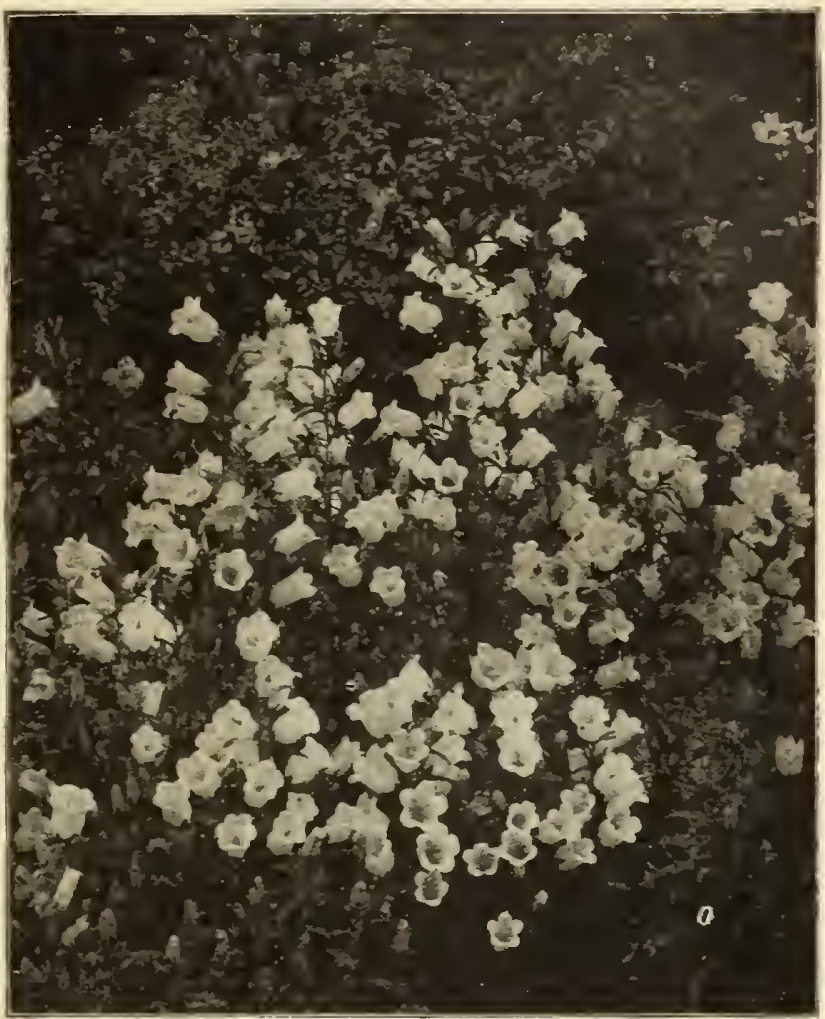

Canterburg Bells

\section{Campanula (Canterbury Bells)}

This old-fashioned flower is a farorite with all. Stately and showy, and of the easiest growth. Hardy biennials.

1560 Livingston's Prize Mixture - An elegant mixture of all the finest classes and colors of single and double and "Cup and Saucer" varieties. Pkt., 10c.; 2 pkts., 15c.

1561 Calycanthema "Cup and Saucer"-Our mixture includes all the best colors and varieties. Pkt., 5c.

1563 Finest Double Mixed. Pkt., 5c, 1564 Finest Single Mixed. Pkt., 5c.

1566 Pyramidalis-The Chimney Bell-flower, a hardy perennial flowering in late summer. Finest mixed. Height, $31 / 2$ feet. Pkt., $10 \mathrm{c}$.

1568 Carpatica-Beautiful free-flowering, hardy perennial; fine for groups and edgings. Blue and White mixed. 9 inches. Pkt., 5c.

\section{Calliopsis, or Coreopsis}

One of the easiest grown annual flowers; can be used with fine effect anywhere-in beds, horders or masses. Blooms all the time. Sow the seed thinly when weather becomes warm and soil dry. 1 to 2 feet.

1530 Hrbrida Superba-Very showy new hybrids in great variety of color, varying from pale yellow to rich orange and velvety brown. 1 foot high. Pkt., $10 \mathrm{c}$.; $1 / 4$ oz., $25 \mathrm{c}$.

1532 Golden Wave (Drummondii)-Bushy compact plants covered with very large bright golden-vellow flowers with brown centers. Pkt., 5c.; $1 / 4$ oz., $15 \mathrm{c}$.

1534 Coronata-Showy, large, pure yellow flowers. Fkt., 5c.;

1536 Mixed Tall sorts-All choice sorts. Pkt. 5c.; oz $25 \mathrm{c}$

1537 Mixed Dwarf Sorts-For bedding. Pkt., $5 \mathrm{c}$.: oz.. $30 \mathrm{c}$.

1539 California Sunbeams (Grandifiora) - An improved largeflowering strain. Fine light yellow and brown blooms Pkt $5 \mathrm{c}$. 1540 Ianceolata Grandiflora (Farvest Moon)-One of the grandest perennial plants. Fine in masses, or as cut flowers. The individual blooms are very large: and of the richest golden yellow. Pkt., 10c.; 1/4 oz., 20c.; oz., 60c:

\section{Balloon Vine}

\section{"Tove in a Puff"}

1496-Rapid-growing, pretty annual climber. delights in a light soil and warm situation: produces white flowers, follorved by seed vessels that look like small balloons; makes a fine porch screen. 10 feet. Pkt., 5c.; oz., 25c.

Bachelor's Button-See Centaurea page 69. 


\section{Cannas}

Cannas seem to be especially adapted to the American climate as they do well everywhere. They grow nicely from seed, and will bloom the first Summer if started early. It is hard to describe the elegance of a fine bed of Cannas. Soak the seeds in warm water until they begin to swell: then sow them in a box in a sunny window or in the greenhouse. When up to the second leaf transplant singly into pots and set out in the garden when the weather has become warm and settled.

1580 I arge-Flowering French Hybrid Cannas, Mixed-Early flowering, and remarkable for large size and beauty of flower and foliage. This collection contains all that is best in Cannas. Pkt., 5c.; oz., 25c

1582 Dark Leaved Cannas-This mixture contains the very choicest varieties we grow in the dark-leaved Cannas. Pkt., 5c.; oz., $20 \mathrm{c}$.

\section{Calendula (Pot Marigold)}

One of the easiest grown, most showy and free-flowering, hardy annuals, producing a fine effect in beds of mixed borders; blooms ail the time; fine for cut flowers. $11 / 2$ feet.

1526 meteor-Yellow striped orange. Pkt., 5c.

1527 Sulphurea Plena-Sulphur Yellow. Pkt., 5c.

1528 Prince of Orange-Darker than above. Pkt., 5c.

1529 Fine Double Mixed-Contains the choicest sorts. Pkt., 5c.; oz., $20 \mathrm{c}$.

\section{Choice Carnations}

Seeds may be sown under glass in the Spring, or in open ground, but must be protected in the Winter. Half hardy.

1586 Giant Marguerite-The flowers enormous; the colors most varied and brilliant, and they come into full bloom in four months from sowing, and continue until hard frosts. Our strains are semi-dwarf and

strong growers, 1 foot high. Our mixture is splendid. Pkt., 10c.

1587 Marguerite Double White-Pure white, large flowers; stiff stalks. Pkt., 10c.

1588 Marguerite Double Yellow-Pkt., 15c.

1585 Iivingston's "Peerless" Carnation Mixture-All bloom the first Summer. A very choice mixture including all superb sorts. Pkt., (about 75 seeds), $15 \mathrm{c}$.

1590 Chabaud's New Giant Perpetual-Comes into bloom in a little over 4 mouths from seed: extra large size; fine range of colors; is very sweet-scented. Mixed colors. Pkt., 10c.

1594 Red Grenadin-For yielding a quantity of double red flowers, no outdoor Carnation can equal it. Pkt., 10c.

1591 Carnation, Giant of Nice-Blooms in four to flve months from date of sowing the seed. The flowers are 1592 Fine Double Mixed-Pkt., $10 \mathrm{c}$.

Canary Bird Vine 1543-Easy-growing, free-bloomgarden. Bright yellow flowers resembling a canary bird with extended wings. 10 feet. Pkt., 5c.; $1 / 2$ oz., $15 \mathrm{c}$.

Migs May Miller, Fairfield Co., O., writes: "The flowers from your mixed bedding petunias and mixed Phlox last

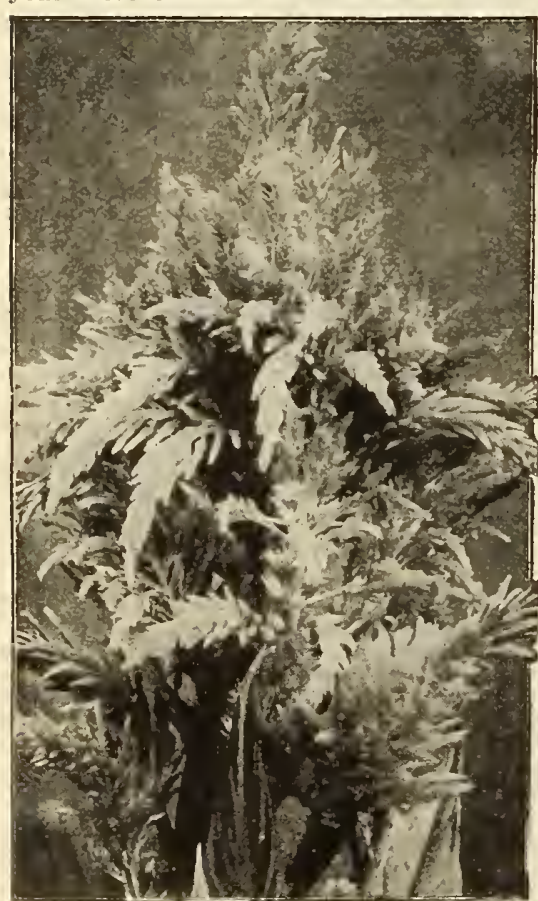

Celosian Ostrich Plume

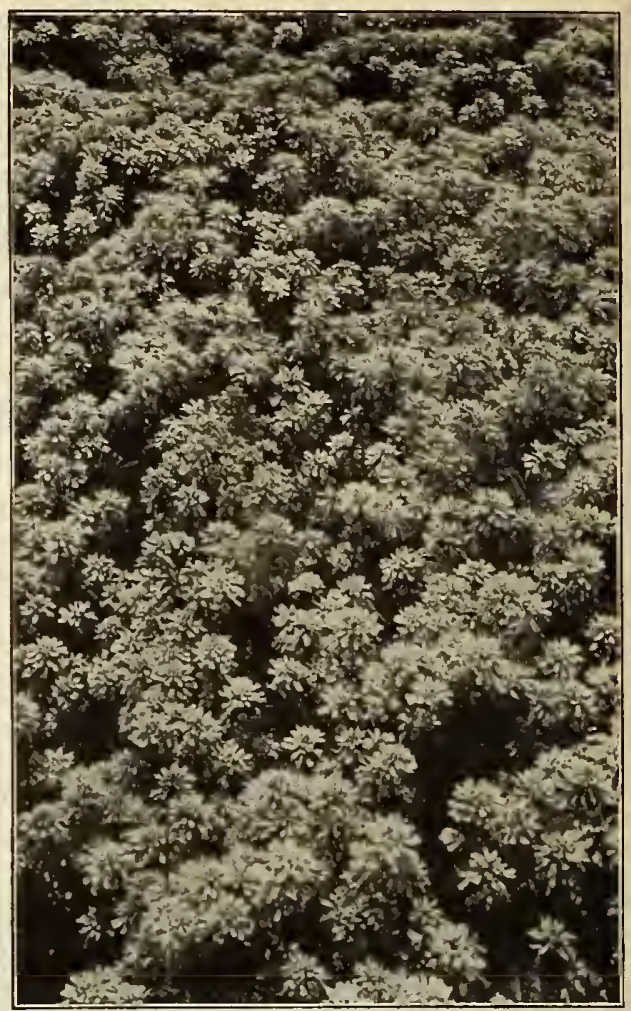

Candytuft

Candytuft (Iberis)

Candytuft is among the most highly prized of Summer lowers, and no garden is complete without a large quantity of it. Grows easily and blooms all the time until frost. plendid for cut-flowers. Hardy annuals. One foot.

1547 Rose Cardinal-Very large umbel of bright rosecardinal flowers, so prolific that a bed presents an unbroken sheet of bloom. Height 8 inches. Pkt., 10c.; $1 / 2$ oz., $40 \mathrm{c}$

1550 Impress, or Giant Hyacinth-Flowered-An improved strain, producing immense trusses of pure white bloom, frequently measuring 4 inches in length by 2 inches through. Fine for bedding and cutting. Height 1 foot. Pkt. 10c. $1 / 4$, 25c. $07,25 \mathrm{c}$

1545 Large-Flowering Dwarf, Mixed

1546 Iarge-Flowering Dwarf, white.

1551 White Rocket-Compact Spikes

es

1553 Odorata-Pure white; most fragrant..................................., 5c.; oz., 25c.

1554 Candytuft, Mixed Annual Sorts-Our mixture contains all of the best varieties and colors. Pkt, $5 \mathrm{c}$; oz, 25c.

1556 Gibraltarica-A dwarf evergreen plant flowering in early Spring and Summer. Much used for rockeries, edging or in the foreground of perennial
borders. A fine little plant worthy of more general cultivation. Lilac, shading to white. Pkt., $10 \mathrm{c}$.

1557 Sempervirens-Similar to the above except pure white. Pkt., 10c.

\section{Celosia, or Cockscomb}

Very attractive annuals. The crested heads of flowers resemble a cock's comb. The plumed heads are like great feathers. (See illustration below.) Sow the seed directly in the garden or start early and transplant. Make fine pot plants.

\section{Ostrich Plume Varieties}

Very graceful. Handsome, pyramidal plants 3 feet high. Each branch gracefully tipped with brilliantly colored plume resembling an ostrich feather. See illustration.)

1600 Thompsoni Magnifica-Mammoth blossoms of vivid scarlet; purple, blood-red, golden yellow, salmon, etc. 2 feet. Mixed colors. Pkt., 10c.; 1/4

oz., 30c Gold Plume-Golden Yellow. Pkt., 5c.

1604 Fire Plume-Fiery scarlet. Pkt., 5c.

Collection, the 3 new Ostrich Plume Celosias, listed above, 15c.

\section{Comb Varieties}

1608 Queen of the Dwarfs-Grows only about 8 inches high. Immense ombs of perfect form; brilliant dark rose. Pkt., 10c. 1609 Glasgow Prize-Large and very showy dark crimson combs. 9 inches.
Pkt.. 10c.: $1 / 8$ oz., $30 \mathrm{c}$. 1610 Empress-Combs of colossal proportions; rich crimson. Pkt., 10c.; 1611 Finest Dwarf Mixed-A choice mixture of all sorts and colors. Pkt., $5 \mathrm{c} . ; 1 / 8$ oz., $25 \mathrm{c}$. 


\section{Centaureas}

The various varieties of this popular annual include such favorites as the Bachelor's Buttons or Corn-Flowers, and Sweet Sultans, old-fashioned flowers of easiest culture. Two feet.

1616 Bachelor's Button (Centaurea Cyanus)-Our strain is especially fine. The true old-fashioned Bachelor's Button of your grandmother's garden. Also called Blue Bottle, Ragged Sailor, Korn Blume, etc. Mixed colors. Pkt., 5c.; 1/2 oz., 20c.; Oz., 35c.

1617 Emperor William-Rich, deep blue Bachelor's Button. Pkt,, 5c.; oz., 20c.

1618 Double Varleties-A comparatively new strain; about three-quarters of the fiowers come double; many choice colors. Pkt., 5 c.; $1 / 2$ oz., $20 \mathrm{c}$.

\section{GIANT-FIOWERING SWEET SUITANS (Centaurea Imperalis)}

The blooms are borne on long stems. Of the easiest growth; very showy the garden all Summer long. (See illustration.)

1620 Giant Mixed Colors-An elegant assortment of colors. Pkt., 5c.; /4 OZ., $25 \mathrm{c}$.; OZ., $75 \mathrm{c}$.

1621 Gfant White-Splendid for bouquets. Pkt., 5c.; $1 / 8$ oz., $25 \mathrm{c}$.

1622 Giant Odorata-Light blue; very large. Pht., $5 \mathrm{c}$.

1623 Giant Suaveolens-The popular yellow. Pkt., 5c.

1627 Iivingston's Choice Mixed Centaureas-A grand mixture of all the above Bachelor's Button and Giant Sweet Sultans. Pkt., 5c.; 1/4 oz., $25 \mathrm{c}$.; oz., $75 \mathrm{c}$.

\section{WHTTE-IEATED CENTAUREAS (Dusty Millers)}

Silver-foliage plants; extensively used for edgings, hanging baskets, etc. 1629 Candidissima-Very thick, broadly cut, slippery white leaves. One oot high. Pkt., $10 \mathrm{c}$.

1628 Gymnocarpa-Leaves fern-like; silvery gray color. Fine for borders. $1 \frac{112}{2}$ feet. Pkt., $5 \mathrm{c}$.

\section{Chrysanthemums}

The annual sorts bloom throughout the Summer, while the perennial varieties are gorgeous in the garden every Fall. The plants grow from I to 3 feet in height.

\section{SEEDS OF ANNUAI VARIETIES}

1632 Double White-Pkt., 5c. 1633 Double Golden Yellow-Pkt., $5 \mathrm{c}$.

1634 Double Sorts Mixed-All the most desirable colors. Pkt., 5c.; 1/4 oz., $15 \mathrm{c}$.

1635 Iivingston's Cholce Mixed Chrysanthemums, Single and Double Sorts-Very desirable for the Summer garden; showy; free-flowering. Pkt., 5c.; $1 / 4$ Oz., $15 \mathrm{c}$.

1654 Tricolor "Northern Star"-Fine hardy annual, with large Daisy-like fowers produced freely on long stems. Pkt., 10c.

\section{SEEDS OF PERENMIAI VARIETIES}

1641 Japanese Hybrds-The best double-flowering varieties. Pkt., $15 \mathrm{c}$.

1642 Frutescens (Marguerite, or Paris Daisy)-Large, ingle white fiowers. Pkt., $5 \mathrm{c}$.

1643 Maximum (Triumph Daisy)-Large, single, pure white, Jellow center. Pkt., $10 \mathrm{c}$.

2433 Shasta Daisy-Pkt., 10c. For description, see page 86 .

1644 Chrysanthemum Inodoram (Bridal Robe)-New; pure white: extra fine, Pkt., 10c.

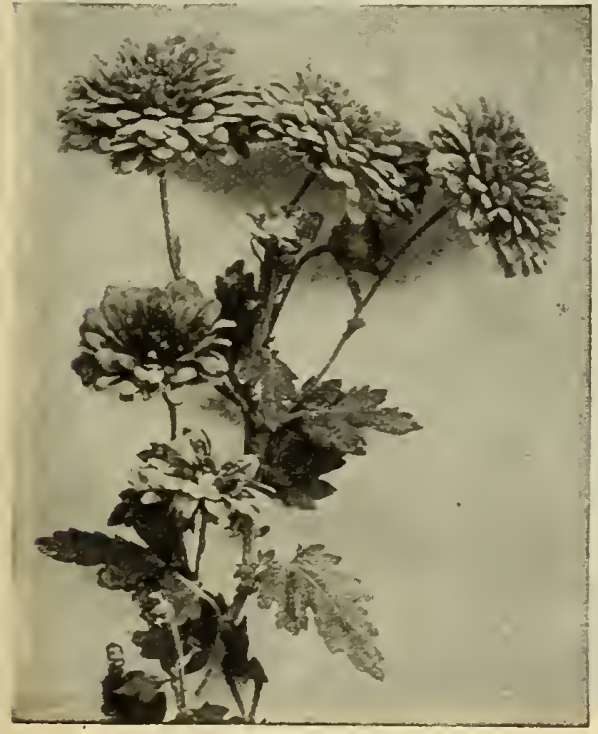

Chrysanthemam, Perennial

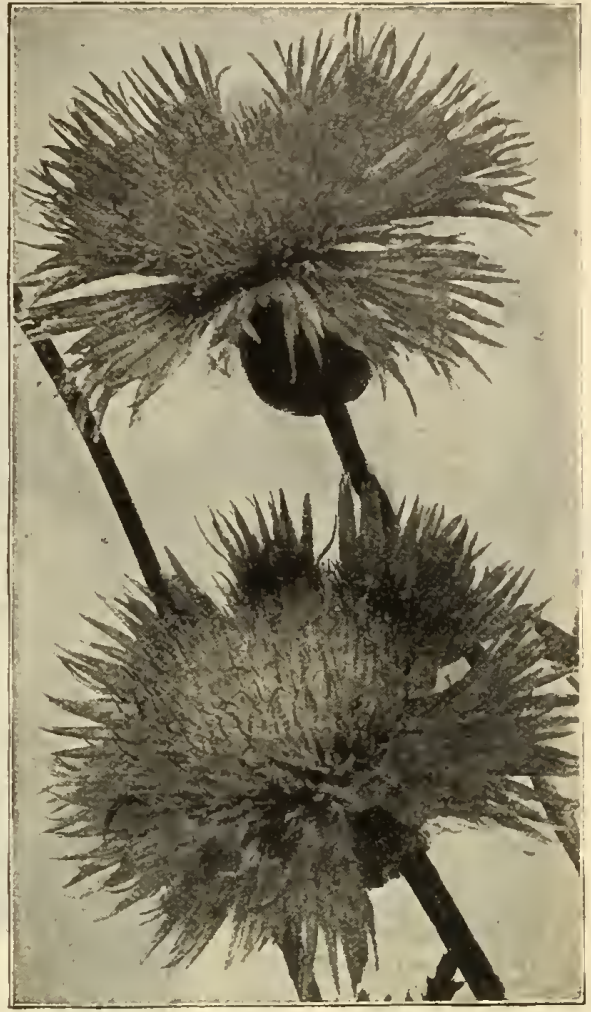

Centaurea Imperialis - Giant-Flowering Sweet Sultan

\section{Cineraria}

A favorite free-fiowering greenhouse plant, with flowers of great richness and diversity of colors. Cinerarias bloom during the Winter and Spring months and can be planted out in summer. The plants thrive best in a mixture of out in summer. The plants

1648 Iivingston's Prize Mixture-Contains only the richest and most beautiful colors; large. Pkt., $25 \mathrm{c}$.

1650 Cineraria Maritima (Dusty Miller)-Silvery white foliage; for edgings, ribbon beds, hanging baskets, etc. 1 foot. Perennial, but usually grown as an annual. Pkt., 5c.; oz., $40 \mathrm{c}$.

\section{Cobaea Scandens}

A fine annual climber, often growing 15 to 25 feet in a season. Has handsome foliage and large bell-shaped fiowers of a beautiful deep violetblue. 1658 - Pkt., $5 \mathrm{c}$.

\section{Coleus}

Beautiful foliage plants, both for greenhouses and bedding out in the garden. The striking colors and brilliant variegated leaves are inuch admired.

1663 Fine Mixed Fybrids-Mixed seed from a very fine collection. Pkt., 10c.

\section{Cyclamen}

These elegant greenhouse plants have the most beautiful foliage and the richest colored fiowers. Seed may be grown in the Spring and Autumn. For large size blooms. substance and brilliant colors, our strains are unsurpassed.

1683 Iivingston's Superb Mixture - Is our best strain; obtained by a continued selection of the choicest varieties of Cyclamen Persicum. The individual fiowers are enormous in size; plants are profuse bloomers The colors are rich and varied Pkt., 25c.

1684 Cyclamen Persicum, Finest Mixed-A choice assortment of varieties and colors. Pkt., 10c.

\section{Cypress Vine}

Ipomoea Quamoclit-This is a beautiful, rapidly growing annual climber, with delicate dark green finely cut fern-like foliage and masses of the most brilliant and graceful star-shaped flowers. The two shades, white and scarlet, are very striking. Planted by the side of a veranda, tree or stake, and trained properly, nothing is prettier. 1686 Pure White-Pkt., 5c.

1687 Bright Scarlet-Pkt., $5 \mathrm{c}$

1689 Finest Mixed-A mixture of pure White and Bright Scarlet. Pkt., 5c.; $1 / 2$ oz., $15 c$.

Inside back cover page contaln our Bargain Flower seed Collections 


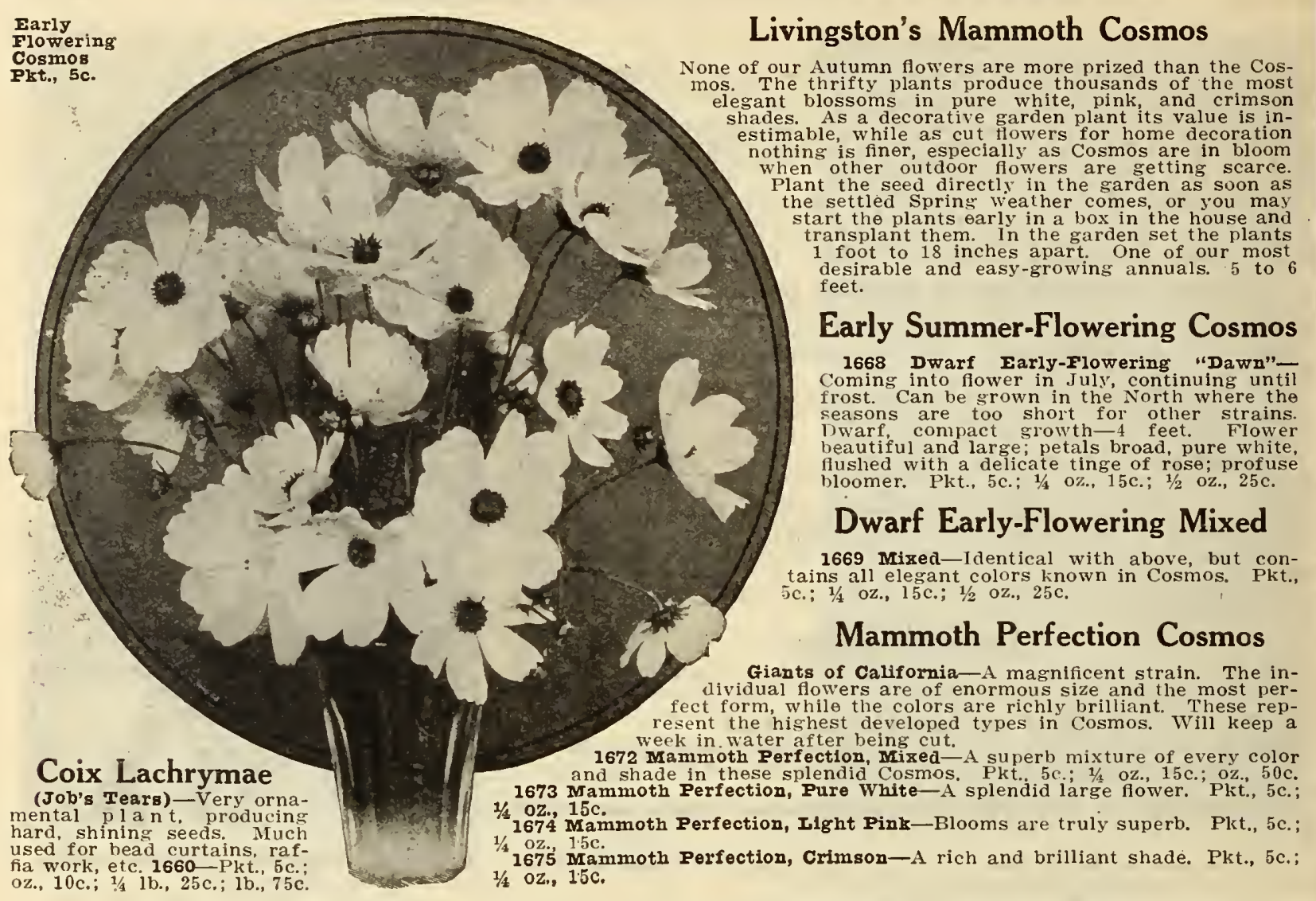

\section{Dahlias}

Dahlias are easily grown from seed and bloom the first season. The earlier they are started the better, which can be done nicely in a box in a sunny window or the greenhouse. Some specimens grown from seed are fully equal to many of the named sorts, and there is always the chance of getting some ontirely new varieties. The single Dahlias are being planted more extensively every year; they are quíck and profuse bloomers, and their colors are especially rich and brilliant.

Do not miss the novelties listed in the front of this catalog.

\section{Seeds from Single Dahlias}

1693 Twentleth Century or Orchid-Flowered-A truly exquisite single Dahlia. Has created a sensation everywhere. Individual flowers are 5 to 8 inches across. Innumerable colors, that have the sheen of velvet. We cannot describe their elegance. Pkt., 10c.

1695 Iarge-Flowering Single Mixed-Splendid assortment of single-flowering varieties. Pkt., $5 \mathrm{c}$.

\section{Seeds of Double Dahlias}

1698 Iarge-Flowering Choicest Double Mixed-This elegant assortment of seed is saved from round, double flowers; many beautiful colors, Pkt., 10c.

1702 Cactus Varieties, Choicest Mixed-Most popular at the present time; distinct and elegant; petals pointed; blooms perfectily double. Pkt., 10c.

1705 Iivingston's Superb Dahlia Mixture-This splendid assortment embraces every variety of Dahlias, both single and double, described on this page, as well as many other fine sorts. Will make an elegant bed at small cost. Pkt., $15 \mathrm{c}$.

Mirś: H. C. Hartwell, Worcester Co., Mass., writes: "Your Foxgloves and Pinks got first prize at our flower contest, blossoms from seed sown last Spring, so there are several people veny anxious for your catalogue, to buy perennial seeds for next. summer's how.

\section{New Gigantic Orchid-Flowered Cosmos 1680 Lady Lenox}

This gigantic Cosmos is the forerunner of an entirely new race of Cosmos. It is of extraordinary size and beauty. Visitors to the fioral exhibitions last Autumn were onraptured with its size and magnificent color Flower 4 to 5 inches in diameter. Color a delightful shel pink, lighting up beautifully at night. 6 to 7 teet high. plendid variets. Plit., $10 \mathrm{c}$; 3 for $25 \mathrm{c}$; $14.4 \mathrm{nz}, 25 \mathrm{c}$.

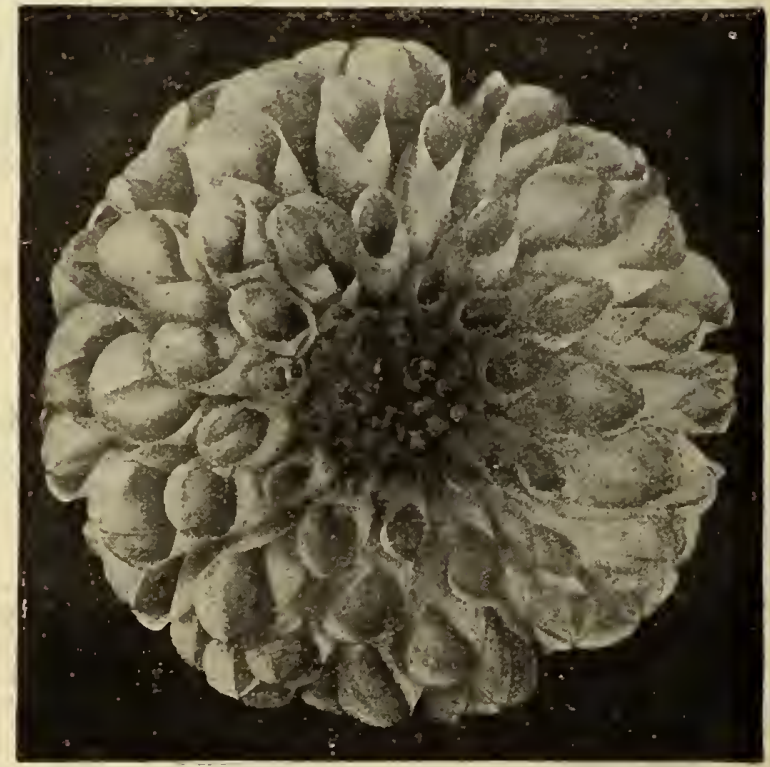

Double Dahlia 


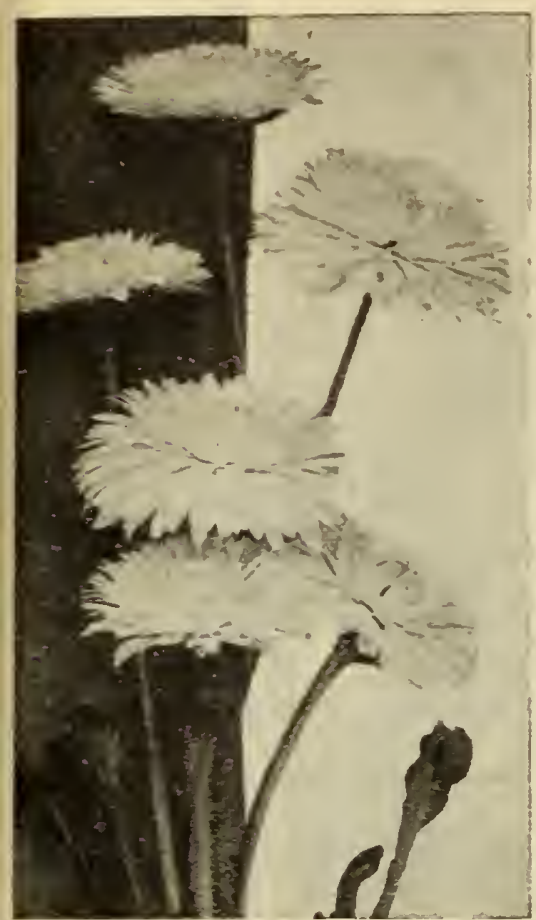

Giant Double Daisies

\section{Giant Double Daisie (Bellis Perennis)}

A charming little plant for pots, edgings and borders. (See illustration.) Sow the seeds very early and plants will bloom the first season and continue to bloom each season if given some protection during Winter. They do best in a rich soil and quite cool stiuation. Especially desirable for cemetery decorations. Perennial. Height about 6 inches.

1710 Giant Iongfellow-A very desirable double sort dark pink; flowers very large. Pkt., $10 \mathrm{C}$

1711 Giant Snowball large and very double pure make fine cut fowers as the stems are very long. Pkt., 10c.

1712 Giant Mixed DaisiesThis assortment includes the Giant Longfellow, Giant Snowmany other finest sorts. Pkt.

1713 Double White-

1714 Double Eose-Clear rose pink. Pkt., $5 \mathrm{c}$.

1715 Fine Double MixedA very choice mixture. Pkt.

\section{Delphinium}

Hardy Perennial Iarkspur-One of our most brilliant and effective hardy garden plants. Of late years the size Persistent bloomers, even in the dryest seasons, 2 to 4 feet. 1726 Sew Giant Flowering Hybrids-These magnificent hybrids, the grandest of Delphiniums in existence, produce splendid spikes of immense flowers. semi-double and double. Flowe spikes are from 2 to 5 feet in length. The colors are very beautiful, ranging from pure white through all the shades of lavender and blue. Mixed colors. Pkt.. 20c.

1732 Formostum - Elegant spikes of the richest dark-blue fowers, with a white center: especially fine for cutting. Four feet. Pkt.. 5c.

1734 Belladonna- Light skyblue flowers, with light centers very fine variety. Four feet Plit., 10c

1735 Zalil-The splendid spikes of bloom are a lovely shade of sulphur-yellow. Four feet. Pkt.

Annua1 Delphiniums.

See Larkspur, page 76.

Mrs. Mary A. Iove, Buchanan Co., Iowa, writes: "I have planted your seed ever since 1815 . They are so reliable, I am afraid to use others. You sent me two neighbors. I know they will send to you for seeds."

J. J. Anderson, of Iake Co. Ohio, writes: "It is a pleasure to me to state that during my several years' dealing with you I have had no cause to complain as to your stock or your prompt and courteous manner of doing business,"

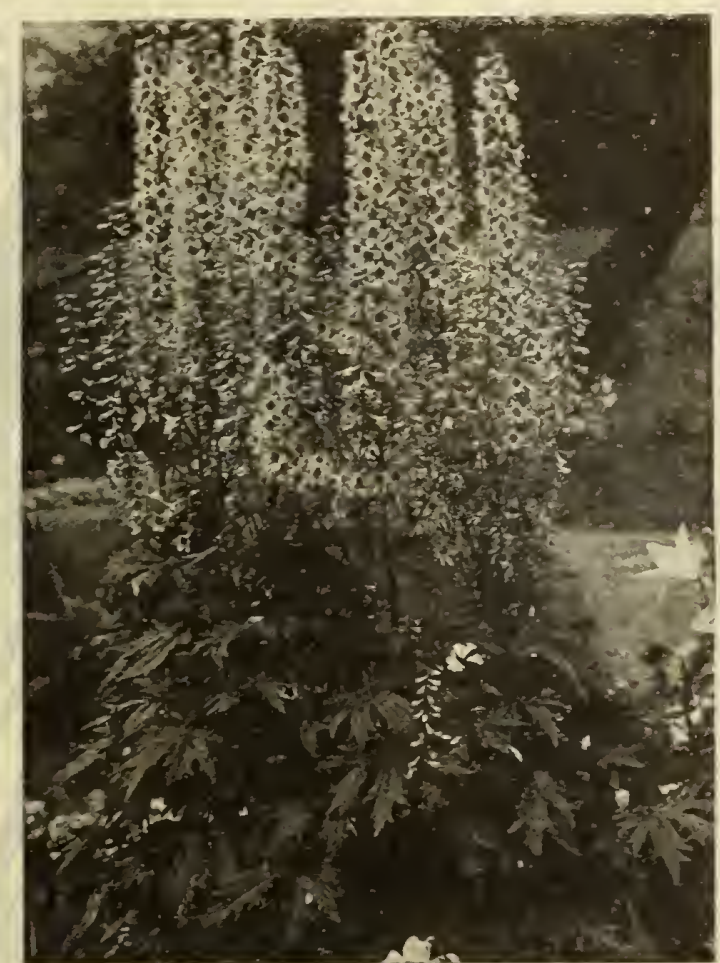

Delphiniam Glant Flowering Hybrids

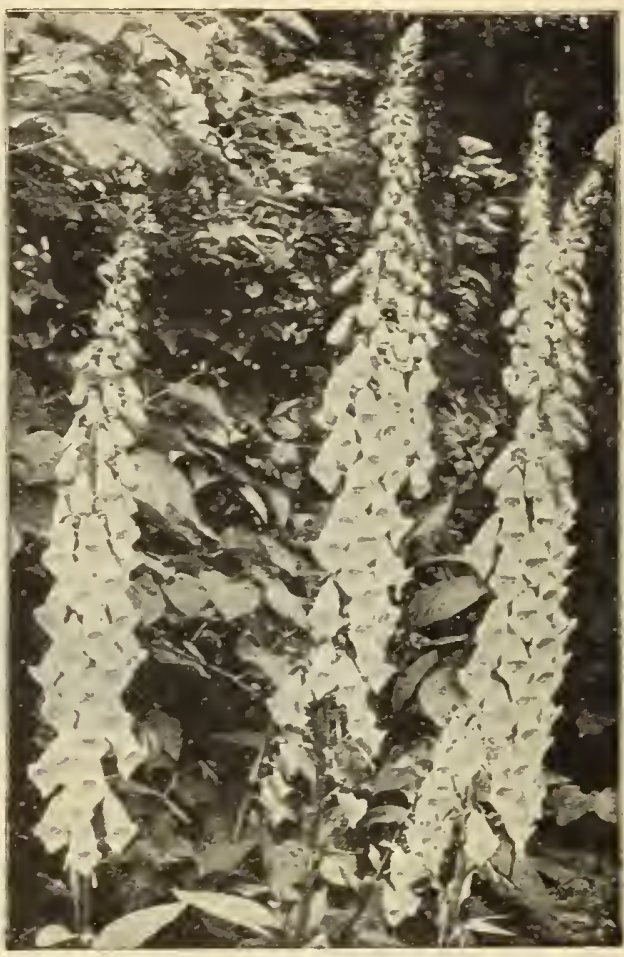

Foxglove (Digitalis)

\section{Digitalis (Foxglove, or Witches Fingers)}

The Foxglove, in common with all the hardy perennials, is being planted more extensively each season. The large tube-like flowers, which are produced so freely in beautiful rdy beds and borders. Being of the easiest growth, and doing tions, they fill in many gaps

1782 Gloxiniaeflora-A beautiful class, with spotted flowers. We offer a mixture of the finest

1784 Grandiflora - A variety that grows about two feet in height. A very fine yellow in or. Pkt., 5c. $1 / 8$ Oz.. $20 \mathrm{c}$.

1786 Monstrosa (Mammoth Fozglove)-A grand strain. The top flowers of the spikes are of enormous size. Our assortment of colors is very fine. Splendid

1788 Purpnrea, Finest MixedThis is the common Fox glove so generally known. Contains many fine varieties. Pkt., 5c.; 1/8 oz. $20 \mathrm{c}$.

\section{Datura (Trumpet Flower)}

Very attractive, bushy plants of easy growth, that during the whole season are covered with shaped flowers. Hardy annual Three feet.

1720 Cornacopia (Horn of Plenty) - A magnificent variety. The blooms average 8 inche long by 5 inches across: the color is white inside, while the outside is most beautifully marbled with royal purple. Pkt. ; $1 / 4$ Oz., $20 \mathrm{c}$.

1722 Finest Double Mixed-A very choice assortment of all the best colors and varieties of this 


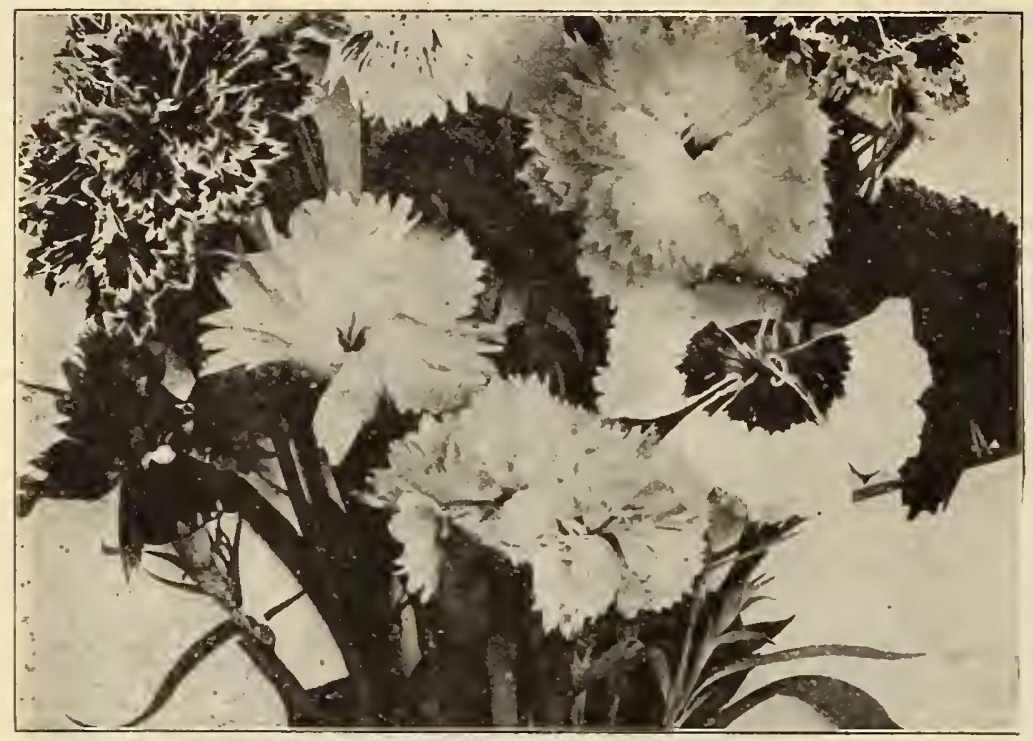

Iivingston's Mixture of Hardy Garden Pinks

\section{Double Annual Pinks}

1740 New Giant Fringed and Ruffled Pinks, Double Marvelous or Japanese Fringed Pinks (Mirabilis Fl. Pl This remarkable and perfectly distinct new strain produces large, perfectly double flowers on stiff, upright stems. The petals are deeply cut into fine strips of threadlike fringes for about half their length, and are twisted in all directions, presenting a novel aspect. In color, they vary greatly, having all shades from pure white to deep
purplish-red. Pkt., $15 \mathrm{c} . ; 2$ pkts., $25 \mathrm{c}$.

1744 Iaciniatas (Double Fringed Pinks)-Magnificent flowers; very large; double. Mixed colors; striped and fringed edges. Pkt., 5c.: $1 / 40 \%$, $25 \mathrm{c}$

1746 Heddewigi (Double Japan Pink)-Flowers very large; perfectly double; many elegant colors and shades, from delicate rose to richest crimson. Pkt., 5c.; 1/8 oz., 20c. rieties of these popular pinks. Our mixture includes a gleat number of colors. Pkt, 5 .

1754 Snowball-Double white, fringed flowers; fine va-

1756 Fireball-A brilliant dark scarlet; plants grow drvarf and bushy; is very fine for bedding or cut flowers. Plit., 5c.: 1/8 Oz., $25 \mathrm{c}$.

1758 Chinensis (China or India Pink) -Our mixture includes all best colors and shades. Pkt., 5c.; $1 / 4$ oz.,

1760 Iivingston's Mixture of Double Pinks-A splendid combination of all the hest rarieties. Prt.

\section{Dolichos}

\section{(Hyacinth Bean)}

A splendid annual climber, with Hracinth-like clusters of
purple and white flowers, which are followed by exceedingly

ornamental seed pods. Is of most rapid growth and stands Summer heat well. Sow the seeds in the garden in May where the plants are to remain.

1796 New White Bush Dolichos-Strong, healthy plants, 18-30 inches tall, according to soil, carry an abundance of elegant flower spikes, 12 to 16 inches long. well above the foliage. Individual flowers measure
about an inch across and resemble a pea flower. As the lowest flowers on stalks drop off, they are followed by ornamental creamy-white seed pods. Bush Dolichos succed anywhere, are highly ornamental planted singly or in rows and bloom continuously from middle of July until frost. Pkt., 10c.

1790 "Daylight"-A splendid variety from Japan. Large snow-white Wistaria-like racemes, that are most fragrant, followed by attractive silver-white seed pods. A very showy and rapid-growing sort. Pht., 5c.; 1,2 oz., $15 \mathrm{c}$.

1792 Purple Soudan-A most decorative climber. The twining stems are of the most intense purple, while the beautiful spikes of bloom are of the richest shade of brilliant rose. Pkt., 5c.; $1 / 2$ oz., $10 \mathrm{c}$.

1794 Finest Mised-Very choice mixture of all the best climbing varieties. Pkt., 5c.; 1/2 Oz., 10c.; Oz., 15c.; 1/4 1b., 50c.

"TrEU BIUE" FLOWER SEEDS give uniformly best satisfaction. We test hundreds of varieties every year in our trial grounds, and know you cannot buy better llower secas, no niutter where ou buy or what you pay. fowering. Should be situation: a sunny Pkt., $10 \mathrm{c}$.

\section{Dianthus or Pinks}

This elegant family contains many of the most valuable and popular flowers in cultivation. All the sorts classed as annuals may be sown directly in the garden as soon as danger from frost is past, and will in a short time become a mass of bloom, and so remain all Summer. Elegant as cut flowers about 1 foot high, and are of easiest culture.

\section{Hardy Garden or Clove Pinks}

This splendid class of hardy perennial Pinks should be in all gardens.

1778 New Double Large-Flowering Grass, or Spice Pinks (Plumarius semperflorens, Fl. Pl.) -One foot high. The flowers, which are beautifully fringed are much larger and more double than the old varieties, while the colors are far richer, including a large variety of colors and markings not known to the old-fashioned Pinks. Many are exquisitely spotted and splashed. They emit a delightful, sweet-scented, spicy odor. Perfectly hardy, requiring only the ordinary culture of the Pinks. They increase in size and beauty every year. Bloom profusely during the Spring and arly Summer. Pkt., $25 \mathrm{c}$.

1772 New Single I arge-Flowering Grass, or Spice Pink, ITized-Same as above, only single. Pkt., $5 \mathrm{c}$.

1773 Plumarius (Pheasant's Eye Pink) - 1 sirgle hard

1774 Double Clove Pink (Plumarius flore pleno)-Double

776 Cyclops Hybrids-Superb, double-flowering red and

$\mathbf{1 7 7 7}$ Livingston's Miztare of Hardy Garden Pinks-1 genificent strain of hardy garden Pinks containing all right and brilliant colors make this mixture one of the

\section{Dimorphotheca Aurentiaca}

1718 Golden Orange Daisy-An extremely showy annual 12 to 15 inches ligh favorite everywhere.

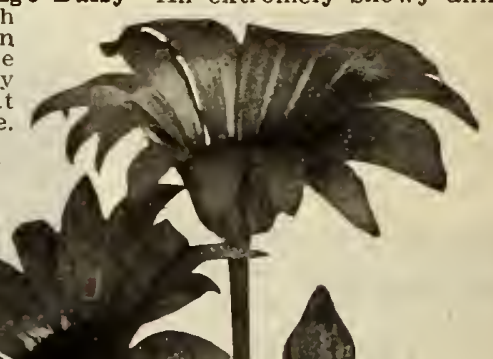




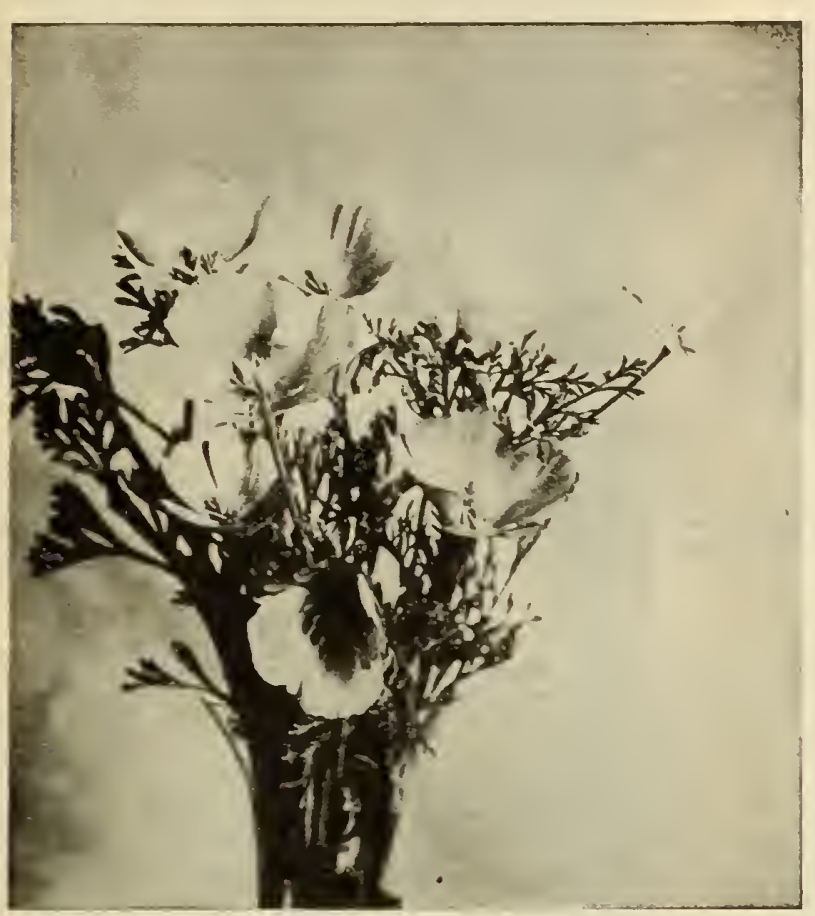

California Poppies

\section{Eschscholtzia (California Poppies)}

Most attractive annuals of the easiest culture, their flowers being very bright and showy. They are splendid for bedding, massing or ribbon-work. The plants grow bushy and about one foot high. They are favorites everywhere. Bloom profusely from spring sown seed.

tration.)

1804 "The Golden West"-Early and continuous bloomer. Magnificent flowers of gigantic size. Color intense shining yellow and orange. The state flower of California. Pkt., 5c.; $1 / 4$ Oz., $15 \mathrm{c}$.

1806 Finest Donble Mixed-A splendid assortment of colors. Pkt., 5c.; $1 / 4$ oz., $15 \mathrm{c}$.; oz., $50 \mathrm{c}$.

1808 Finest Single Mixed-All the best varieties. Pkt. $5 c . ;$ oz., $25 \mathrm{c}$.

1811 Bush Ischscholtzia (Hunnemannia)-A fine new perennial plant; forms a bushy shrub 2 feet high, producing large cupshaped flowers on stems 12 inches long; of clear jonquil yellow and vivid bright orange stamens. Begins to bloom in July from jpring-sown seed. Pkt., 5c.

\section{Gaillardia (Blanket F1ower)}

There are Annual and Perennial Gaillardias. The Annual sorts loom all Summer and Autumn, and are noted for the profusion. size and brilliancy of their flowers; excellent for beds and borders. The Perennial varieties are grand and wonderfully effective in the hardy borders their especial value being constant blooming from July until hard freezing weather. They require no Winter protection, although applications *f $^{*}$ manure increase their strength. If the seed is sown early they will begin flowering at mid-summer. Both classes are splendid as cut flowers. They are of the easiest culture, doing finely anywhere. Height 2 feet.

1830 Finest Single Annual Mixed-A very fine assortment of many brilliant colors. Pkt., $5 \mathrm{c}$.

1832 Tinest Double Annual Mixed (Iorenziana)-All the best double-flowering varieties in richest mixture. They bloom freely all the season. Splendid for bouquets. Pkt., 5c.

1834 Grandifora Hybrids, Finest Mixed-One of the most elegant perennials; is in continuous bloom from June until frost. The enormous flowers are a magnificent combination of red and yellow. Splendid to cut for vases. Pkt., 5c.

1836 Grandiflora Compacta-A compact-growing variety similar in bloom to the Grandiflora Hybrids, but only grows about 15 inches high. Its flowers are of the richest colors, and the stems are long. - A very fine variety. Pkt., 5c.

Chester E. Brown, Harain Co., Ohio, writes as follows: "My garden this year was not as much of a success as it was last, due to the fact that last year's garden was started with "True Blue" seeds and this year with "patronize home trade" seeds. My next year (if I have a garden) will be from "True Blues."

\section{Erigeron \\ Speciosa}

1770 - hardy pernnial, bearing retty blue flowrs for a long pewo feet high Useul in hardy borer. Pkt., 10c.

\section{Echeveria} ren and Chickens are asily grown from seeds.

contains a n shapes and col$1797 \mathrm{M}$ i $\mathrm{x}$ ed

\section{Feverfew}

(Matricaria) 1824 - Free-flow ring an nuals bout 1 foot high: ery compact and Splendid beds and borers; also fine as pots. The double, white blooms are ery useful in bou Pt., $10 \mathrm{c}$.

Don't forget to look for Novelties on Page 7.

\section{Fuchsias (Lady's Eardrops)}

These well-known plants will flower the first season from . if started early. As house plants for Winter they .

826 Best Sorts Mized-Pkt., 15c.

Four O'Clock-Marvel of Peru, page 76.

Forget-Me-Not-See Myosotis, page 79.

Flower seed Collections are on Inside of Back Cover Page

J. P. Poland, Hampden Co., Mass., writes: "I wish to peak particularly of the new Aster 'Sensation,' the seed which I obtained fron you. Everybody admired, them. the others all had the blight. I shall recommend you to

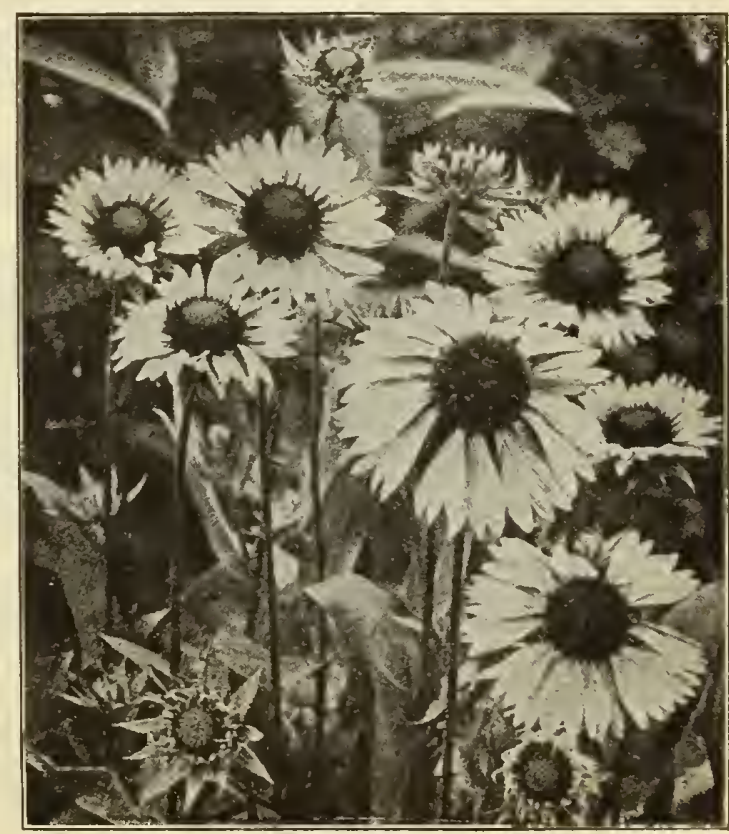

Gaillardia Grandifora 


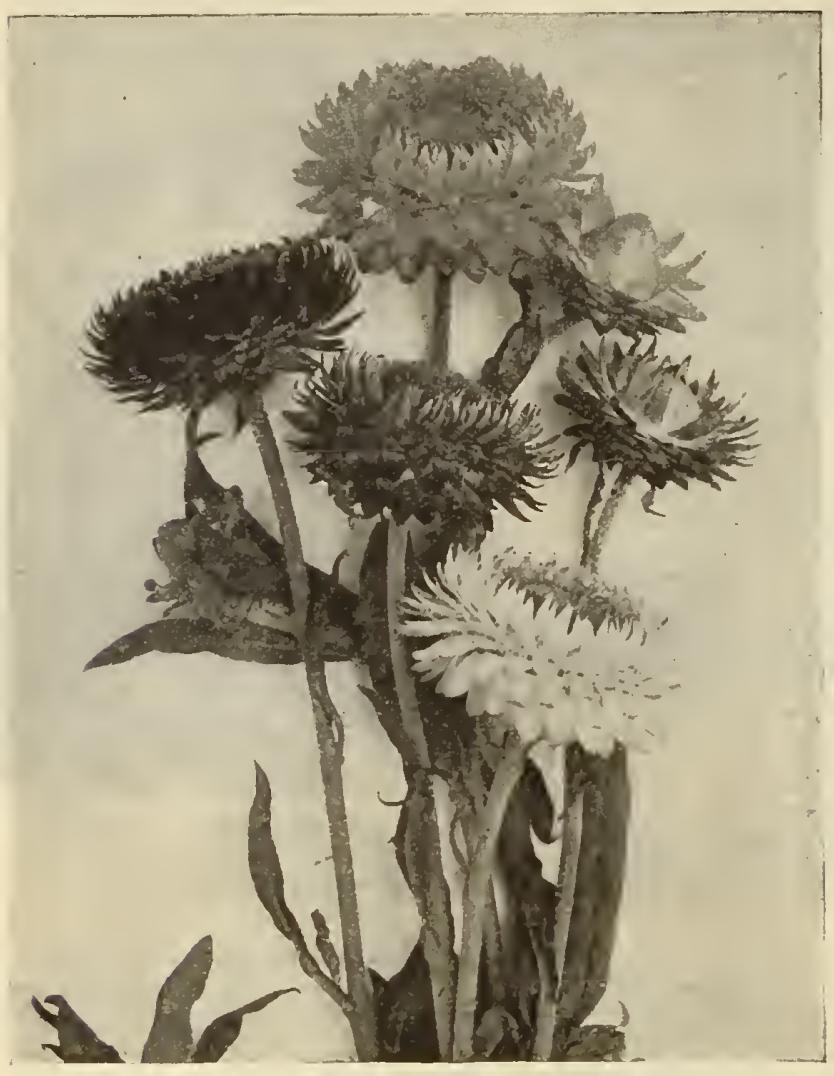

Helichrysun

\section{Hibiscus (Marshmallow)}

Tall growing; especially adapted to backgrounds and shrubbery horders. Of easiest culture, and bloom the entire season. Plants grow $t$ to 5 feet tall.

1890 Africanus-A very choice annual variety. Flowers ellow, with maroon center. Pkt., 5c.

1892 Crimson Eye-The beautiful white flowers. with deep crimson centers, are of immense size, often 6 to 7 inches in diameter. Perfectly hardy. Pkt., 5c.

1994 Mallow Marvels-A robust type of upright habit, producing an abundance of flowers of enormous size in colors. Pkt., $10 \mathrm{C}$.

\section{Heliotrope}

Easily raised from seed. Spring planting gives fine Summer blooming plants. As a bouquet flower it is always a favorite.

1880 Lemoine's Giant Hybrids-Grand flowers, double the size of the older sorts. Bushes compact, about 18 inches high; heads of mammoth blossoms often measure a foot across. Deliciously fragrant. Seed shown in the Spring will produce flowering plants by July, which continue in flower until frost. Mixed, including purple, white, lavender and blue. Pkt., 10c.

1882 Dark Varieties Mixed-All best dark blue and lavender shades in mixture. Pkt., $5 \mathrm{c}$.

1884 All Sorts Mixed-In best assortment; all shades, both light and dark. A. very desirable strain. Pkt., 5c. Hardy Garden Heliotrope-See Valeriana.

\section{Godetia (Satin Flower)}

in attractive and very beautiful hardy annual. In full bloom all summer, so profuse that the foliage is almost hidden by the large wide-open flowers; of shining satiny texture and the most delicate and brilliant colors. Our mixture contains all the best varieties. $1 \frac{1}{2}$ feet. 1854 Irixed-Pkt., $5 \mathrm{c}$.

Chester E. Brown, Fardin Co, Ohio, writes as follows: "My garden this year was not as much of a success as it was last year, due to the fact that last year's garden was started with 'True Blue' seeds and this year with was started with 'True Blue' seeds and this year with 'patronize home trade' seeds. My next year
garden) will be from "True plues."

\section{Gourds}

1862 Bath-Sponge, or Dish Cloth-A most admirable natural dish cloth is furnished by the peculiar spongelike lining of this fruit. Pkt., $5 \mathrm{c}$; $1 \frac{1 / 2}{\mathrm{Oz}}$., $20 \mathrm{c}$; $0 \mathrm{oz}, 35 \mathrm{c}$. 1865 Dipper-Used for dippers; 9 to 12 inches long hold from 1 to 4 pints; will last for years. Pkt., $5 \mathrm{c}$. oz., $25 \mathrm{c}$.

1868 Japanese Nest Egg-Exactly like a hen's egg in shape, color and size. Pkt., 5c.; 1/2 oz., 15c.; oz, $25 \mathrm{c}$.

1871 Snake, or serpent-Has long fruits, sometimes

feet, and striped like a serpent. Pkt., $10 \mathrm{c}, ; 3 \mathrm{pkts} ., 25 \mathrm{c}$. 1872 Sugar Trough-Holds 4 to 10 gallons; hard, thick hells; very light, strong and durable. Pkt., 5c.; oz., 25c. 1860 Gourd Mixture-Contains all of the ahove menioned sorts. Pkt., 5c.; oz., $20 \mathrm{c}$.

\section{Gypsophila Paniculata (Baby Breath)}

\section{An elegant hards perennial plant that should be in} every garden. It is not only pretty in beds, but its delicate little flowers, produced in feathery white panicles, and branching foliage lend a daintiness to bouquets that is most elegant. Its sprays are much used in making up bouquets of Sweet Peas. 1878-Pkt., 5c.

\section{Geraniums}

These popular plants are most easily raised from eed, and if started early will produce flowering plants the first Summer. Start in the house and transplant to the garden as soon as the weather is warm. You will find that the varieties we offer are of very superior quality

1842 Finest Mired-Pkt, $10 \mathrm{c}$.

1843 Iarge-Flowering Double varieties - Splendid strain; seed is saved from the finest double sorts. Pkt., $25 \mathrm{c}$.

1844 Variegated-Ieaved Sorts-Bronze, gold, stlver and tri-colored foliaged varieties, Elegant collection. Pkt., $15 \mathrm{c}$

1845 Iady washington-These are the well-known rich-colored showy Pelargoniunis. Our mixture includes all the best varieties. Pkt., 20c.

1846 Apple-Scented-The old-fashioned favorite apple-scented Geranium. Plit., $10 \mathrm{c}$.

\section{Helichrysum (Straw Flower)}

A hardy annual of the earliest culture; one of our best "Everlasting" flowers, the dried double bloom being very handsome in winter bouquets. Two feet. 1888 Mixed-Pkt., 5c.; $1 / 4$ oz., $20 \mathrm{c}$.

Mr. Charles Adams, Fayette Co., Ind., writes: "The package of Lan'n Seed and F"lower Seed rou mailed us arrived all $O$. K., and we feel that we now have seed that will make is successful."

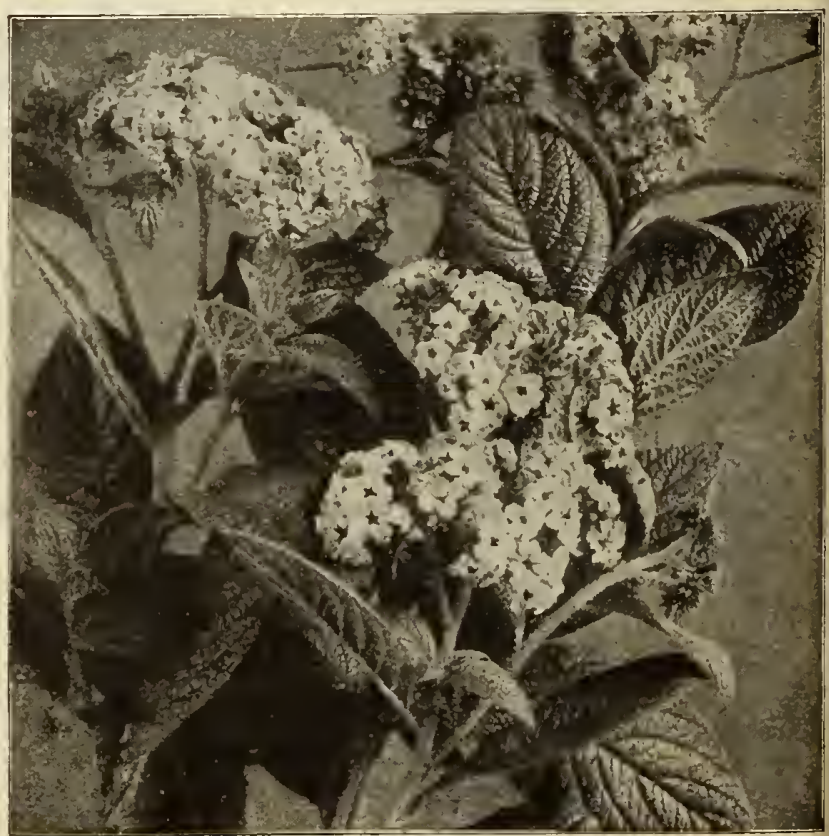

Feliotrope. Pkt., 10c. 


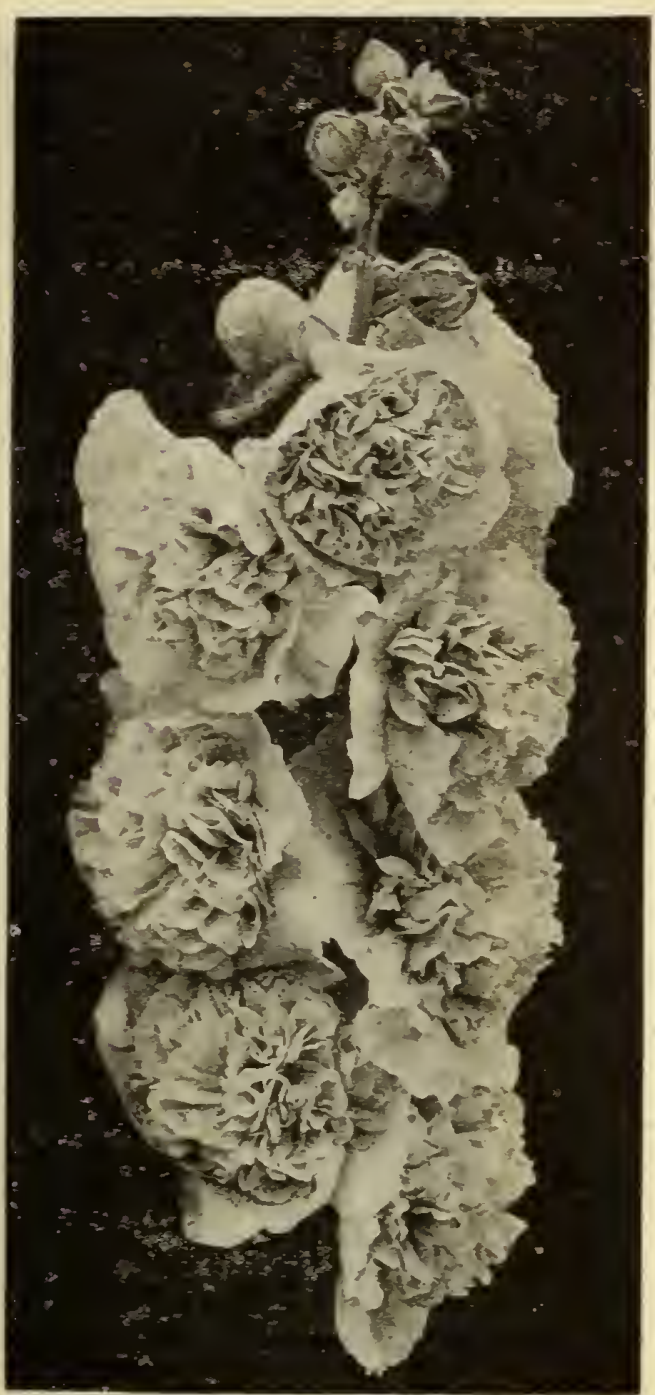

Iivingston's Prize Eollyhocks

\section{Impatiens (Zanzibar Balsam)}

A very pretty plant for house culture, and the garden as well. Its flowers are very rich colored. They are borne in great abundance, and the plants are continuous bloomers. Tender pernnial. Two feet. 1928 - Pkt., $10 \mathrm{c}$

\section{Holstii Hybrids}

Very handsome Zanzibar Balsam discovered in Africa. It forms bushes $1 \frac{1}{2}$ to 2 feet high and resembles above, but surpasses it in its quicker and more vigorous growth and its larger and brighter colored flowers. Seed sown indoors in Spring will form plants ready to set out in May. 1930 - Mixed-Pkt., $15 \mathrm{c}$.

\section{Kudzu Vine}

1936 Pueraria Thunbergiana-This wonderful climber is of Japanese origin and is the most luxurient and rapid-growing vine known in horticulture. It will grow 8 to 10 feet the first year from seed, and after becoming established will produce vines 50 feet higl in a season, sometimes growing 12 inches in a single day. Produces a tuberous root which is perfectly is very luxuriant, quickly forming a dense shade. Unequaled for porches, arbors, trellises, etc. Pkt., $10 \mathrm{c}$; 3 pkts., $25 \mathrm{c}$

\section{Kochia Tricophylla}

1934 Sammer Cypress, or Burning Bush-This splendid annual plant grows very quickly from seed sown in the open ground as soon as the weather permits in Spring. The plants always make attractive globe-shaped bushes, as large sometimes as 3 feet high and 2 feet across. Leaves slender and of a light pea-green color until September, when.ther.turn to carmine and blood-red: at same time ends of shoots are thicklv set with small hright scarlet flowers and produce a very striking effect. Pkt., 10c.: 1\% oz, 20c.: oz., 35 c.

\section{Hollyhocks}

Hollyhocks require a rich soil, but it must be well drained. We seed of the finest quality. Once thoroughly established, they bloom stronger and more brilliantly every year. Seeds sown early, and the oung plants transplanted several times, will bloom the same

\section{Livingston's Prize Hollyhocks}

These are the largest flowering and most perfectly double Holiywe have been abte to procure after many years of selection of We believe our strain to be unsurpassed in every respect. We offer

1896 Double Black, 1897 Double Iemon Yellow, 1898 Double White, Double Rose Pint, 1901 Double Crimson, 1904 Double Scarlet,

\section{Livingston's Prize Mixture}

This is our best mixture. It is composed exclusively of the finest veties. It contains not only the above elegant

\section{Mammoth Allegheny}

Its lovely arranged, fringed and transparent the palest pink to deepest red. In form the flowers are double semi-double and single. Plants are in full bloom from July until

\section{New Annual Everblooming Hollyhocks}

These glorious new hybrids may be grown from seeds and will fower the same year as quickly as any garden annual. The plants the beginning of May in the open ground will commence to flower about the end of July, ten days after Hollyhocks that have been treated as biennials. 1913 Mixed Annual Hollyhocks-Pkt., 10c.;

\section{Humulus (Japanese Hop)}

Splendid climber. Has handsome foliage, which resembles that of

1922 Silver-Ieaf Japanese Hop-Unusually beautiful variety of rapid-groming Summer climbing vine Leaves deep green, beautifully striped and blotched with silvery white and gray. Will reach a height

\section{Ice Plant (Mesembryanthemum)}

very pretty trailing annual that has fleshy, wax-like leaves. which have the appearance of being covered with ice crystals. Splenid for rock-work, vases or hanging baskets. Flowers are white.

\section{Kenilworth Ivy}

1932 Iinaria Cymbalaria A hardy perennial trailing plant suitable for vases, etc. Adapted to shady locations. Easily grown from foliage. Pkt., 10c.

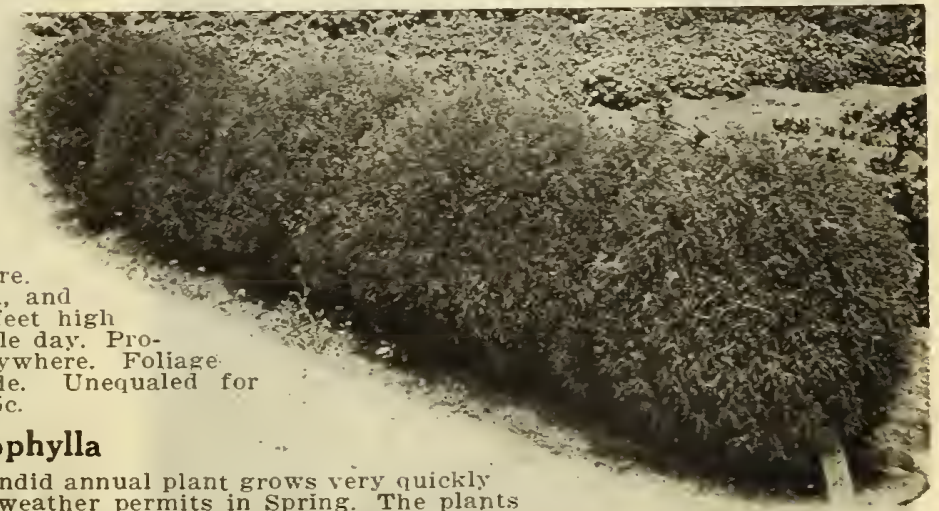

Kochla 


\section{Lantana}

Popular, free-blooming and very rapid-growing plants with flower heads of various colors, which are continually changing; emit a powerful aromatic perfume; plants are completely loaded with blossoms, succeeded by berries, which, when ripe, turn deep blue. Used largely for bedding out in Summer and are also tine $11 / 2$ feet. 1938 mixed-Pkt., 5c.; 1/8 oz., $15 \mathrm{c}$.

\section{Larkspur (Annual Delphinium)}

1945 Azure Fairy-Annual variety of Larkspur and a most beautiful shade of blue. It grows about 12 inches high period. It is very hardy and satisfacperiod. It is very hardy and

1944 Stock Flowered Larkspnr-These tall-growing and branching Larkspurs produce the most brilliantly beautiful in bloom all Summer. Ill colors mixed. Pkt., $5 \mathrm{c}$.

1947 Dwarf Hyacinth-Flowered - Resembles a Dutch Hracinth in style of bloom. Our mixture includes a very fine Povendula vera) True Lavenderrange of colors and shades. Pkt., 5c.; fine for mixed border. Three feet. $1 / 8$ oz., $25 \mathrm{c}$

1949 Giant Hyacinth Flowered-Tall, a superb class. The splendid flowers are very large, very double and of various beautiful colors, shadings and markings; long spikes of bloom like immense hyacinths. Pkt., 10c.; $1 / 8$ oz., $30 \mathrm{c}$.

1951 Double Dwarf Rocket-A most hoice mixture of varieties, that grow about 1 foot in height. Pkt., 5c. 1\% Oz., $15 \mathrm{c}$.

1953 Double Tall Rocket-This wellknown mixture embraces the very choicest colors in the taller growing

Perennial Larkspur-See Dephinium.

(Ievendula vera) True Tavender1957-Pkt., 5c.

\section{Lobelia}

Exceedingly pretty, profuse blooming plants of great value both in the garden and for hanging-baskets, window boxes and vases, especially prized for edgings of beds and borders. Plants grow about 6 inches high, They are treated as annuals and are of the easiest culture.

1958 Crystal Falace Compacta-Best dark blue sort for edgings and carpet bedding. Pkt., 10c.; 1/8 oz., 50c.

1960 Emperor William-A brilliant, compact-growing light blue; a very fine

1962 Gracilis-Fine for hanging-baskets, vases and window boxes. Light blue, a trailing variety. Pkt., $5 \mathrm{c}$.

1964 Mixed Compacta Sorts-A very fine mixture of all the best varieties for edgings and bedding, Pkt., 5c.

\section{Lychnis}

Few plants produce as bright flowers and bloom as continually as Lychnis. A hardy perennial, but fowers the first season from seed if same is sown early. Two feet.

1971 Finest Mixed Hybrids-Plants are compact and bushy; colors include all the most brilliant shades, from pure white to deepest red. Pkt., 5c.

Mrs. A. K. Gossom, Gravin Co., Okla., writes as follows: I have ordered my Sweet Pea Seed from you for ten years, and have never had a failure. My Peas are the talk of the neighborhood."

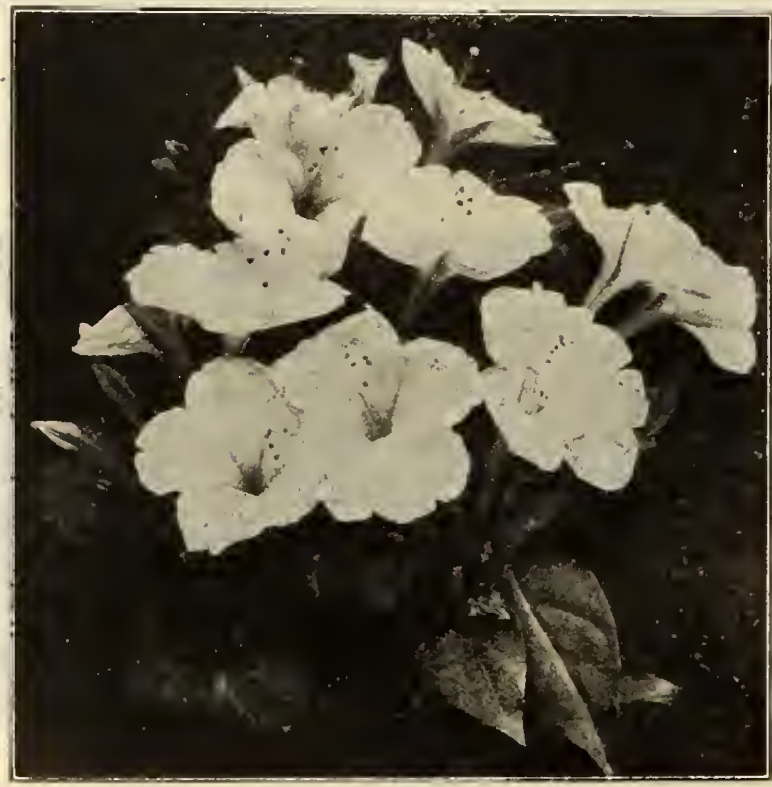
Lavender

If you are intending to plant a flower garden and are undecided as to just what to plant refer to inof this catalogue where you will find our "Rainbow Collection" of annual flowers, at $50 \mathrm{c}$ and also our "Bright Array"

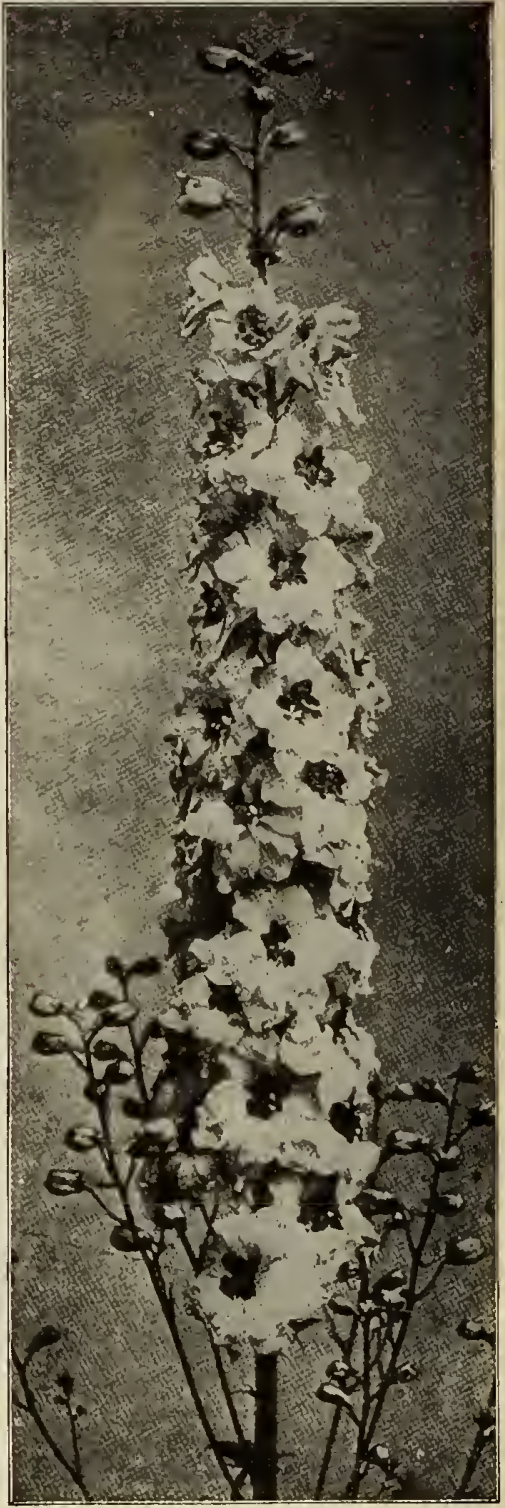

Iarkspur

\section{Marvel of Peru (Four O'clock or Mirabilis)}

This old-fashioned favorite is one of our easiest grown annuals. The plants are bushy, about 2 feet high, and completely covered all Summer with large, showy, very fraglant bloms.

1995 Variegated-The brilliant flowers, in many colors, contrast finely with the golden-hued foliage. Plkt., $5 \mathrm{c}$; 0 z., $20 \mathrm{c}$ 1997 Finest Mixed-An elegant assortment of these oll fashioned favorites. Pkt., 5c.; oz., 15c.; 1/4 1b., $45 \mathrm{c}$.

\section{Maurandya}

Elegant twining, climbing plants, with handsome foliage and flowers. They bloom profusely all summer in the garden, and are also particularly adapted for the house and conservatory. 1999 Blue, White and Mauve, Mixed-Plkt., $10 \mathrm{c}$.

\section{Mimulus (Monkey Flowers)}

Very showy and free-blooming plants, having brilliant and greatly varied blooms. Fine for pots, or in the garden. They do best in rather shaded, moist situations. One foot.

2018 Tigrinus-Striped and spotted varieties; very fine. Pkt., $10 \mathrm{c}$.

2020 Moschatus (Musk Plant)-Fine for hanging baskets, etc. Small yellow flowers. The foliage has a strong odor of musk. Pkt., 5c. 


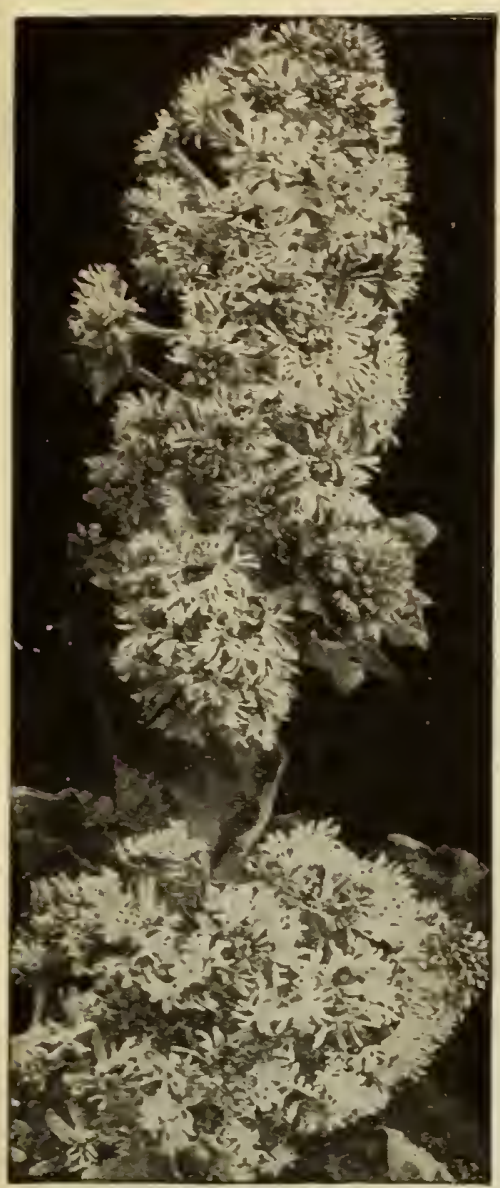

Mammoth Red Goliath IIgnonette, Pkt., 10c.

\section{Mignonette (Reseda)}

Witlout Mignonette in our gardens, something indeed would be missing. Its large deliciously fragrant spikes ot bloom are everyone's admiration. Make successive sowings in the carden from April to July for continuous bloom until frost: and if the plants are thinned out to six inches apart and the tops pinched off when about two inches high, stronger plants, with larger spikes of elegant lonm, will be the result. Height 1 to 2 feet. according to the variety.

2001 Mammoth Red Gollath (See Ilustration)-This is the ideal Mignonette for garden or pot culture. Of strong, stocky growth, luxuriant rich green foliage. Brancling habit; dense in length and $2 \frac{1}{2}$ inches in diameter. Surpasses all others orillancy of color. Strong. delightful fragrance. Pkt., 10c.; 4 oz., 35c.

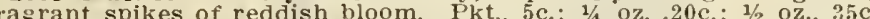

2006 Golden Machet-A distinct variety of the above, having golden-yellow flower spikes. Very sweet and elegant. Pkt., $10 \mathrm{c}$ : $1 / 407 ., 20 \mathrm{c}$. 2007 Defance-Has immense spikes or

2008 Victoria Red-An elegant sort; fine flower-spikes of the most brilliant Pkt., 5c.; $1 / 4$ oz., 20c.; $1 / 3$ oz., 35c.

2009 Golden Queen-A very compact-growing sort; flower spikes golden yellow. 2010 2011 Sweet Mignonette (Reseda Odorata)-The old fashioned, deliciously sweet-

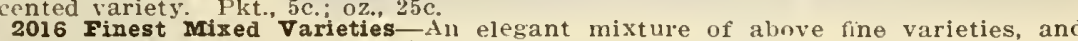
many other choice sorts. Pkt., 5c.; $1 / 4$ oz., $15 \mathrm{c}$; $1 / 2$ oz., $25 \mathrm{c}$

\section{Livingston's Superb Marigolds}

These old-fashioned favorites are annuals of the very easiest cultivation. Both the French and African classes are very effective, the former have the small, velvety flowers, in pretty combinations of yellow, brown, maroon and striped effects; the African sorts are the enormous flowered ones, in very showy orange and lemon shades. (See illustration.) Both kinds are most popular for beds and borders, and planted in large blocks are very attractive. They bloom profusely all summer. Start the seed early in a box in the house or plant directly in the garden when the weather is warm. Fine as cut-flowers, French sorts make nice pot plants.

\section{African Marigolds}

1974 Mammoth Lemon Queen-Flowers very large; rich lemon color: double $19^{-6}$ Mainmoth Orange Prince-Enormous double blooms, of an intense, very

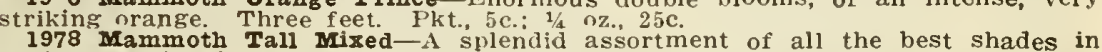
African Marigolds. Three feet. Pkt., 5c.; 1/2 oz., 25c.; oz., 40c.

1980 Mammoth Dwarf Mixed-The flowers are enormous in size, but the plants grow dwarfer. $1 \frac{1 / 2}{2}$ feet. Pkt., $5 \mathrm{c} . ; 1 / 2$ oz., $25 \mathrm{c}$.; $0 z_{.}, 40 \mathrm{c}$

\section{French Marigolds}

1984 Iregion of Fonor (Iittle Brownie)multitude of flowers. In color it is a velvety golden yellow blotched with purple. One foot. Pkt., 5c.; 1/4 oz., 20c.

1988 Tall Double Mixed-A splendid as-

sortment of all the best colors in striking combinations. $2 \frac{1 / 2}{2}$ feet. Pkt., 5c.; $1 / 2$ oz., 25 c.; oz., $40 \mathrm{c}$.

1990 Dwarf Double Mixed-Similar mixture to No. $19 S 0$ in colors, but the plants row much dwarfer. One foot. Pkt., 5c.; $1 / 2$ oz., $25 \mathrm{c}$.: 0z., 40c, See Novelties, Page 7.

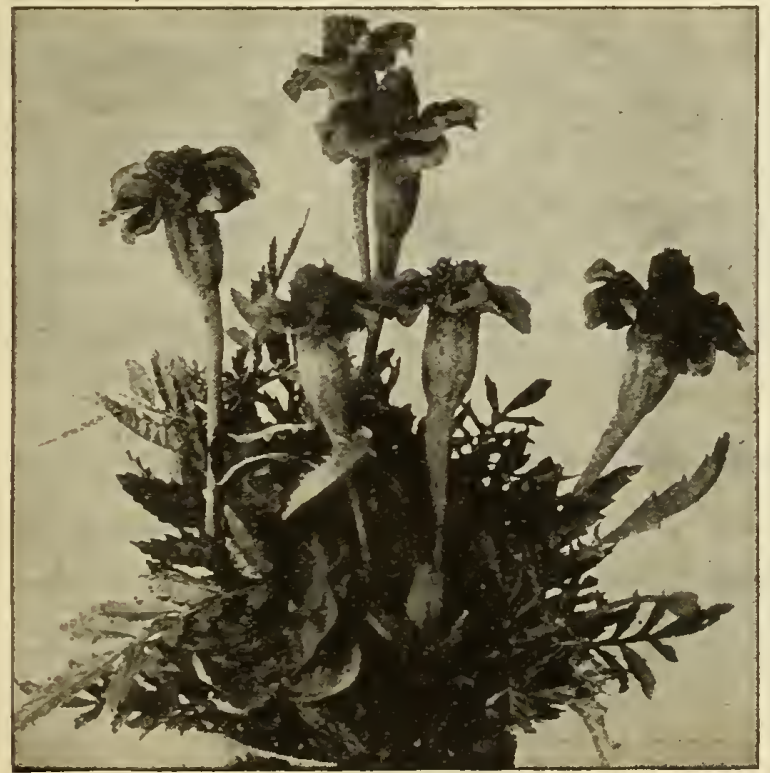

Iegion of Honor (Little Brownle) Marigolds

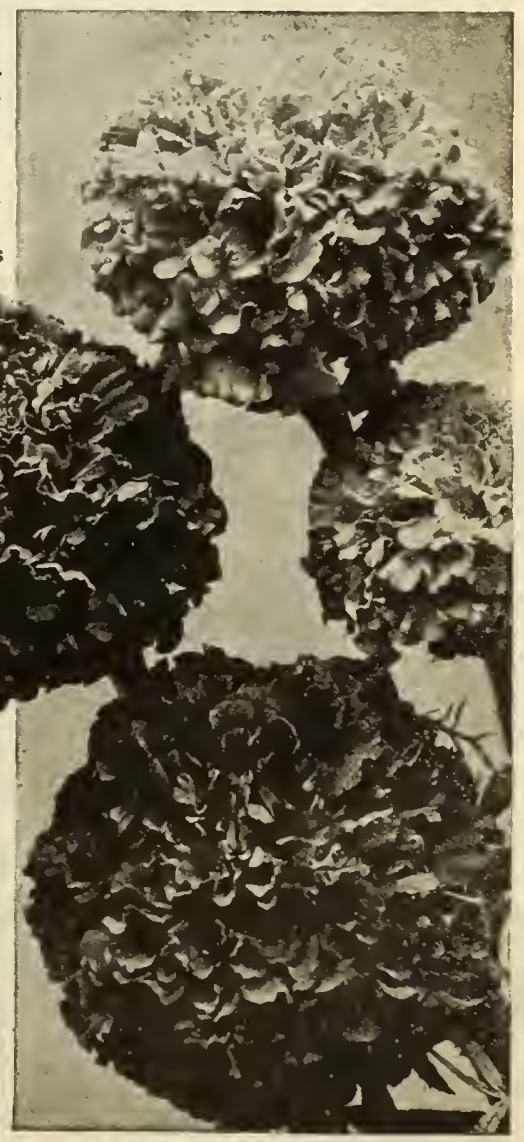

Superb African Marigolds
Livingston's "True Blue" Flower Seeds are grown for us by specialists who have had years of situated where the c 1 i $\mathrm{m}$ a $\mathrm{t} e$ is best suited to their perfect deveropment. You will take little risk in using them. 


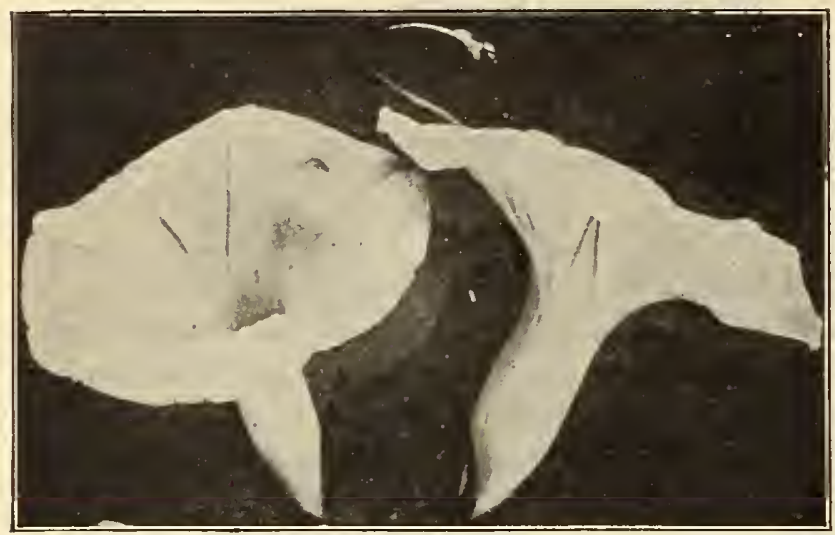

\section{Moonflowers}

(Impomoea Noctiflora-See Inlustration Below)

Splendid annual climbers of most rapid growth, with beauticul and varied flowers; for covering old walls, trellises, arbors or stumps of trees, they are valuable. The seed should be lightly cut at the end and soaked over night before planting.

2038 Northern Iight-The earliest blooming of all the Moonflowers. Its lovely pink flowers are produced by the thousands, all Summer and Fall. Pkt., $10 \mathrm{c}$.

2040 Moonflower, White-Seeded-The variety most generally grown, being large in flower, firm in texture, and very fragrant. It bears in greatest profusion its immense lovely, white flowers, 5 to 6 inches in diameter. with a 5 -pointed star in the center. Pkt., 10c.

2042 Moonflower, Cross-Bred or Hybrid-A variety of great value for the North, as it is in bloom a month earlier than the above. Flowers are pure white, large and fragrant. A very rapid grower; 20 to 40 feet. Pkt., $10 \mathrm{c}$.

2046 Ipomoea Rubro-Coerulea (Heavenly Blue)-The popular climber; has immense blooms of bright sky-blue. Very fine sort. Pkt., 10c.

One Pkt. of each of above 4 Moonflowers, $30 \mathrm{c}$.

\section{Morning Glories}

2024 Giant Imperial Japanese-One of the most valuable and popular annual climbers introduced in years. This strain of mammoth-flowering Morning Glories is most justly celebrated for the veauty of both flowers and foliage. Magnificent in size of bloom4 to 6 inches across. The great variety of rich and delicate colors. tints and markings is wonderful. Our mixture of seed of these is tints and markings is wonderful. Our mixture of se

\section{New Cardinal Climber}

\section{(Ipomoea Ouamoclit F Yhrida)}

A new annual climber of the Ipomoea or Morning lory family.

It is a wonderfully vigorous grower, climbing 20 feet n a season from seed sown in the spring. The foliage is beautifully cut and is very graceful. The flowers are very brilliant, being a fiery scarlet, the individual blooms eing about $11 / 2$ inches across and produced in clusters of to ?. It flowers very profusely the entire summer and bids fair to take a nlace as one of our best annual climbers, having atracted much attention wherever orown. lt snoinld be planted un a warm sunny location in sooi soil and will then give a good account of itself. 1598Pkt., $15 \mathrm{c}$

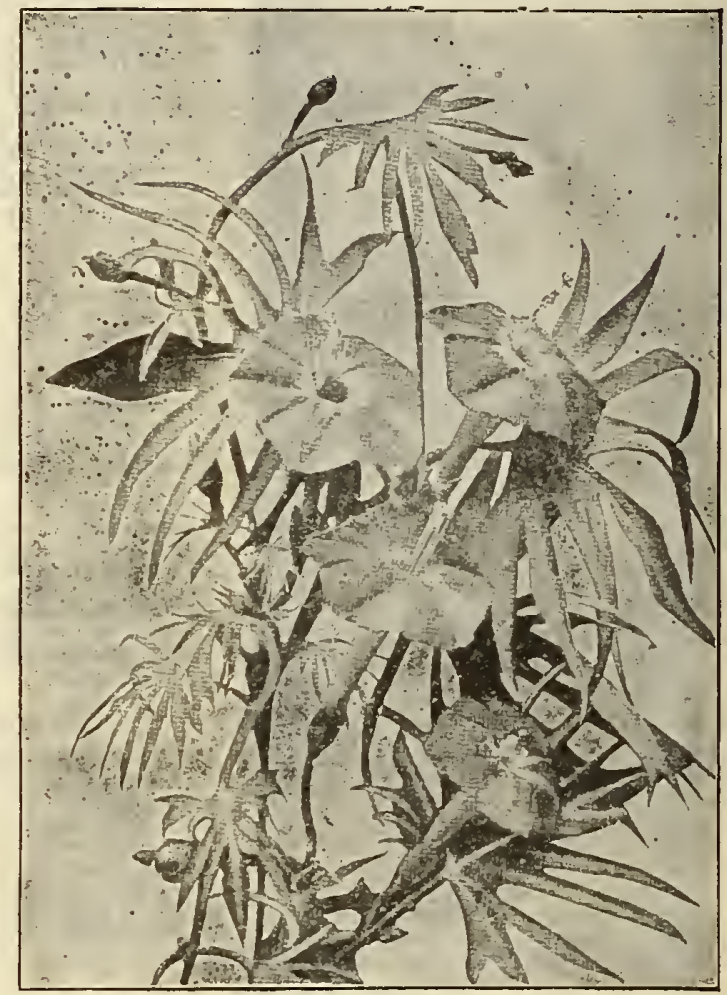

Cardinal Climber

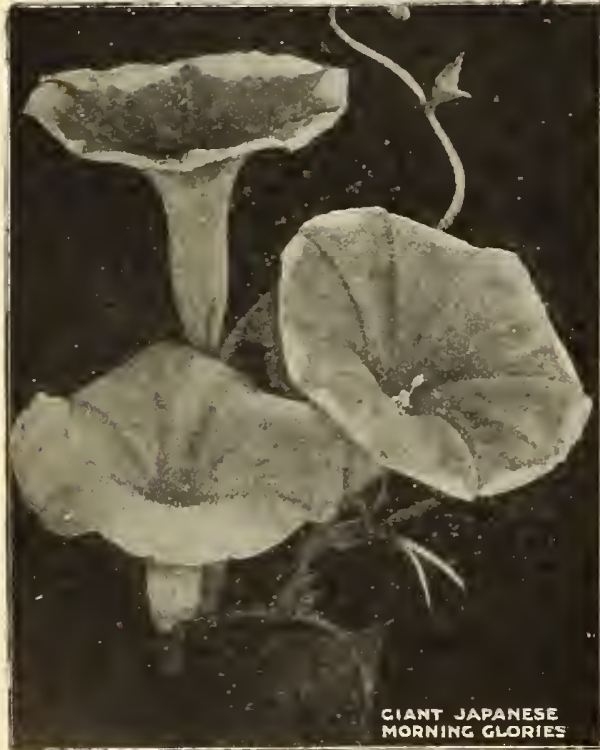

2026 Finest mixed Japanese-Very choice strain; flowers large, and in greatest variety of colors and shades. Pkt., $5 \mathrm{c}$.; $1 / 2$ oz., 10c.; oz., $15 \mathrm{c}$.

2028 Fancy Fringed Japanese-This is a splendid mixture, made up exclusively from the best fringed varieties. The range of color is very great and fringed-edged blooms very beautiful. Plit., 10c.; 1/2 0z., 25c.; oz.

2022 Morning Glories (Convolvulus Major) - These are the old-fashioned favorites that everybody loves. No climber is more useful, as they grow so quickly and cling to anything. Splendid mixed with other vines. especially Nasturtiums. Our mixture contains all the choicest and brichtest colored sorts. Pkt., 5c.; oz., 10c.; $1 / 41 \mathrm{~b}$., $25 \mathrm{c}$.; 1b., $75 \mathrm{c}$.

2030 Brazilian Morning Glories (Ipomoea Setosa)-This desirable climber makes a thick dense grov'th of great lobed leaves, and is brilliant with an endless profusion of immense clusters of rosy-colored flowers, with a satiny-pink star in the center of each. Pkt., 10c.

\section{Dwarf, or Bedding Morning Glories}

Beautiful and showy plants, producing an abundance of richly-colored flowers, which, in fine weather, remain opell all day, Hardy annual. One foot.

2036 Choice mixed-A very large assortment of these richly-colored favorites. Pkt., 5c.: oz., $15 \mathrm{c}$.

R. Blickenderfer, Laclede Co., MLo., writes: "Enclosed find 25c. for your seven varieties of Sweet Peas, Spencer variety. Those we received from you last year did extra fine: they were without doubt the finest in the city.'

Mr. Floyd H. Ferrell, Hocking Co., Ohio, writes: "I have had good success with your seeds last year and I think they are surely True Blue seeds indeed" 


\section{Myosotis (Forget-Me-Nots)}

The Forget-Me-Not is an old favorite, bearing clusters of star-shaped flowers. Succeeds best in id moist, shady situarion, and blooms the first year from seed sown early. Sped sown in Autumn flowers in early spring. Hardy peren-
nial. 2050 Palustris (True Forget-Me-Not)- Reautiful blue; 6 inches. Pkt., 10c.

2051 Alpestris-Bright blue. Plit., 5c.

2054 Semperflorens-Splendid dwarf Forget-Ne-Not; will thrive in sun or shade; covered from ealy to late with beautiful blue flowers. Pht., $5 \mathrm{c}$

2058 Finest Mixed Varieties-A Forget-Mle-.jot Mixture of all the finest sorts. Plit, je.

\section{Livingston's Giant-Flowering Nasturtiums}

Giant Golden Yellow-Mammoth flowers, frequently $3^{16}$ inches in diameter; borne on long, strong stems well above the foliage; exquisitely formed with overlapping crinkled petals and distinct valiet 2066-Tkt., 5c.; 0\%, $20 \mathrm{c}$.

Giant Cream Pink-The extremely large flowels full expanded form; the daintiest of all Nastur tiums. Its superb roloring is of blush cream fushed with rose. Nothing we can say can coi are splendid substance. 2068-Plit., 5c.; $0 \mathrm{z}, 20 \mathrm{c}$.

Giant Deep Crimson-The deepest and richest o all dark-red Nasturtiums. The foliage is-dich green; the mammoth flowers, which are borne in reat abundance, have a soft, velvety texture lightly crumpled petals ing. $2070-$ Pkt., $5 \mathrm{c}$.; oz., $20 \mathrm{c}$.

Giant Striped Hybrids-A gorgeous strain of brilliantly striped beauties of varicus shades and tints; gigantic in size. Its wonderful variety of colors and markings show mant unique combinations. 2071-Pkt., 5̌c.; oz., 20c.

Giant Brilliant Scarlet-1 glowing, flaming scarlet, intense and rivid; the largest of its color of splendid substance and beautiful form. 2072 -Pkt., 5c.; oz., 20 c.

\section{Perfection Collection of Giant- Flowering Nasturtiums}

\section{7} IARGE PACKETS of these
Wonderfully Beautiful Kinds,
postpaid, to any address, for

\section{Livingston's Top-Notch Mixture}

A wonderful diversity of rich colors and new and striking combinations are found in this unequaled mixture. A row in full bloom is beyond description, containing shades of yellow, rose, scarlet, orange, lemon, bronze, maroon, ruby, cream and pink, both in solid colors and mottled and striped in many show and exquisite ways. For many years this mixture of Nasturtiums has been our special pride Every year we have improved it, until now we unresitatingly offer our new Giant-Flowering Nasturtiums as absolutely the finest. We strongly reconnend our customers to plant liberally.

2100 Top Notch Mixture of New Giant-Flowering Nasturtiums-A large packet, 1 nc.; oz.; 20c.; 1/4 1b., $50 \mathrm{c}$.

2094 Mized Tall Nasturtiums-There is no flower of which you need seed in larger quantities for liberal planting than Tall or Climbing Nasturtiums. For the low price, this mixture is very choice. Pkt., 5c.; oz., 15c.; 1/4 1b., 40c.

\section{Ivy-Leaved Trailing Nasturtium}

This is a most distinct variety, both in flower and foliage. The plants are of very sturdy running growth, and the leaves, which are of a deep green, veined with silvery-white and star-
like, resemble the hardy English Ivy. The flower are intense glowing scarlet and most distinct in form the petals beino finely feathered Fspecially graceful in hanging baskets, window boxes and vases.

210ג Scarlet-Pkt., 10c.; 1/2 oz., 20c.; oz., $30 \mathrm{c}$
Giant Iemon and Rose-Grand, extra large flowers of clear pale lemon, varying to bright yellow; beautifully

Giant Rose-A most desirable variely, with flowers of a ft rosy-pink color: foliage light green. The brightest

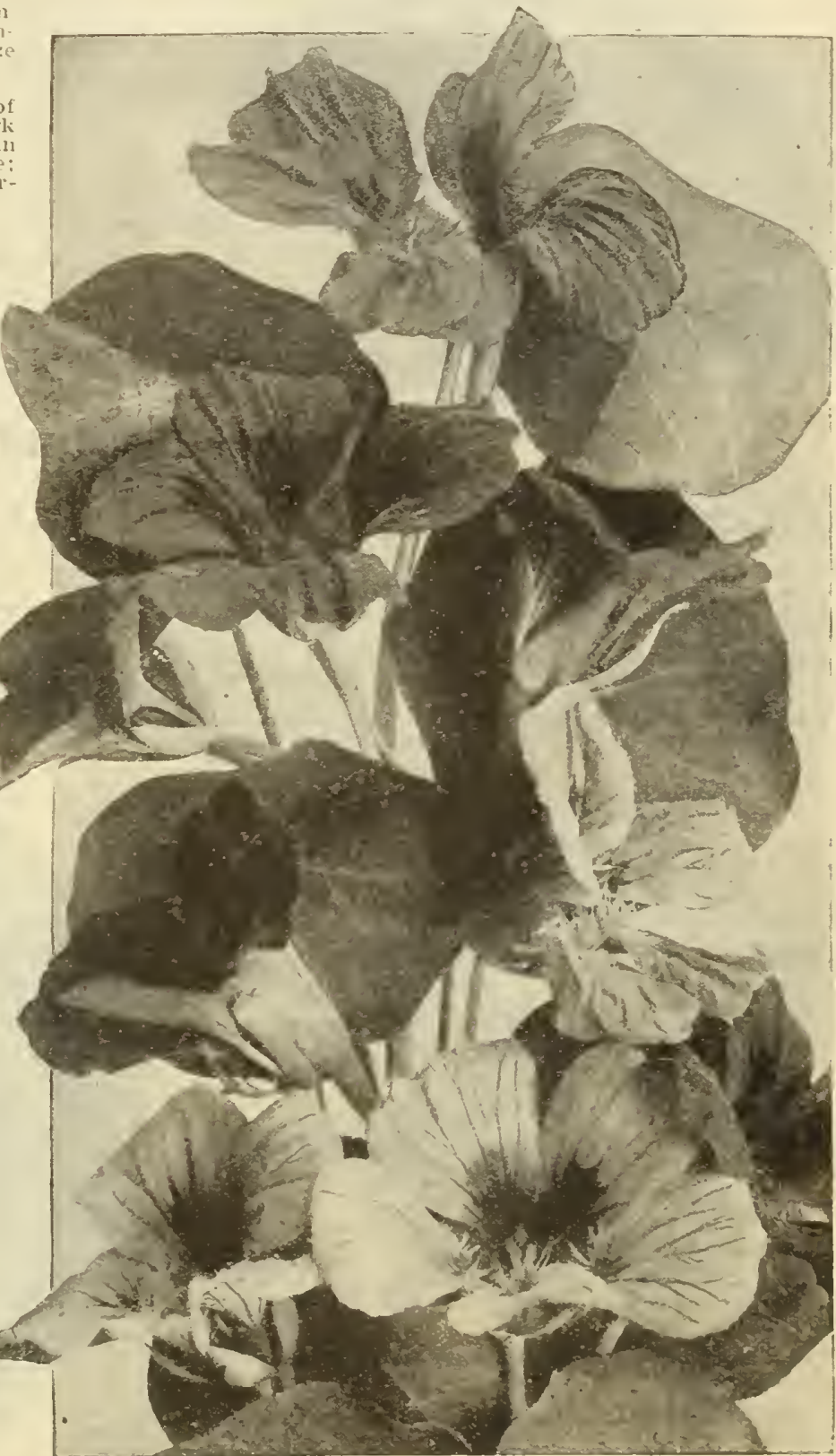

Specimen Flowers from Iivingston's Top-Notch Mixture 


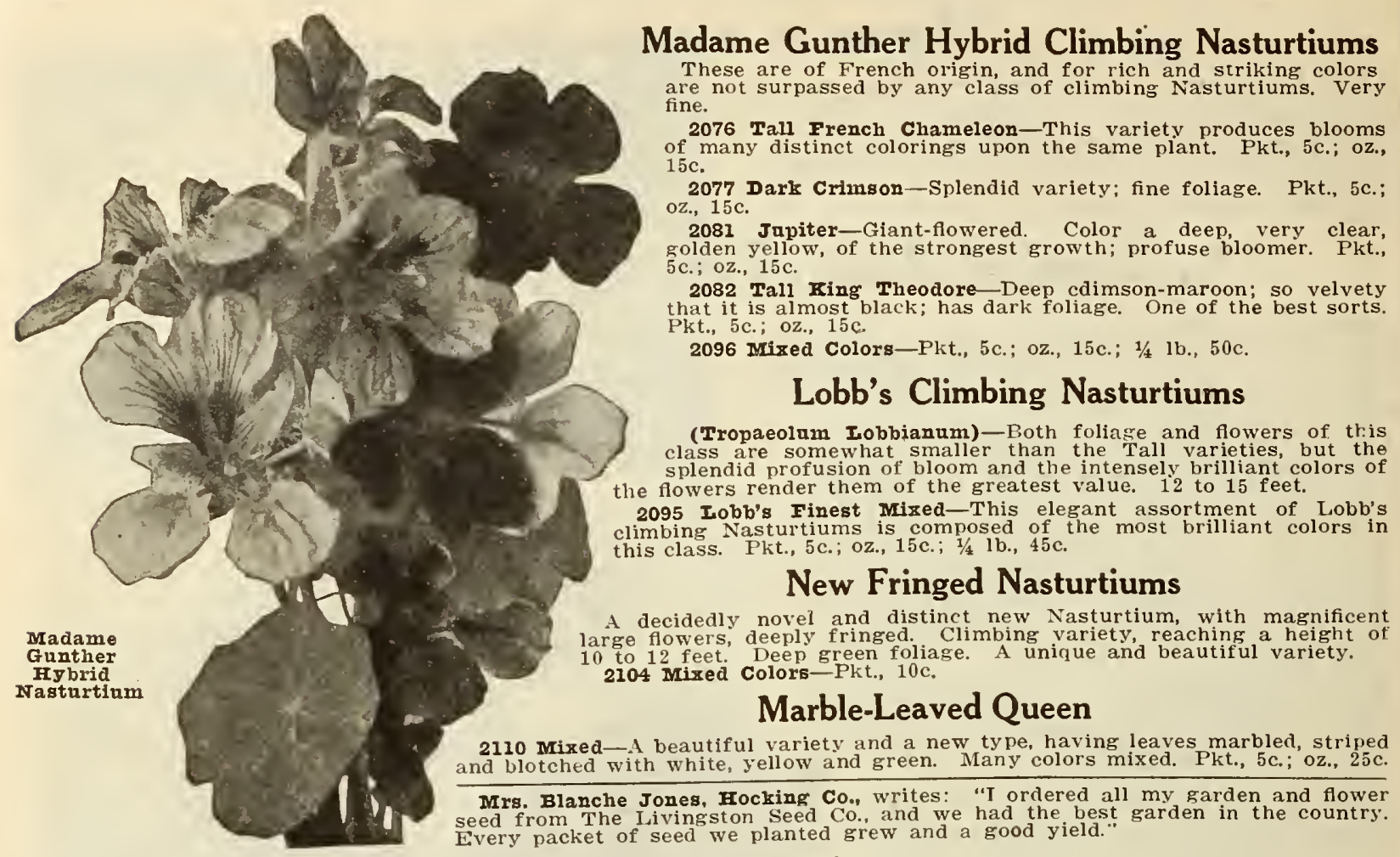

\section{Dwarf Nasturtiums}

2135 Golden King-A rich orange-yellow. Foliage dark. Pkt., 5c.; 0z., $25 \mathrm{c}$.

2136 King of Tom Thumbs-Glowing, darkest scarlet flowers. Foliage very dark green. A most rich and brilliant variety. Pkt.; 5 c.; Oz., $25 \mathrm{c}$.

2137 Dwarf $\mathrm{King}$ Theodore-A velvety crimson-maroon, almost black. The leaves are the darkest in Nasturtiums. Pkt., 5c.; oz., 25c.

2133 Dwarf Chameleon-Of brilliant shades and diversified markings; some self-colored, others splashed and mottled. Pkt., 5c.; oz., $25 \mathrm{c}$.

2134 Empress of India-A very compact-growing sort, having purplish-green leaves; the flowers are fiery crimson. Pkt., 5c.; oz., $25 \mathrm{c}$.

\section{Dwarf Liliput Nasturtims}

This charming and distinct new class has very small flowers and leaves. In growth it is very compact, bushy and dwarf, being more so in both respects than the Dwarf 2152 Mixed-Pkt., 5c; oz, $25 \mathrm{c}$.

Queen of Holland (New Iillput Hybrids) - A dainty type of very dwarf growth, making fine compact little bushes only, about 6 inches high. The flowers, although smaller than the regular Nasturtiums, are ver'y brilliant in color and are produced in a wonderful variety of shades and combinations, including cream, rose, scarlet, orange, crimson-all beautifully blotched.

2131 Mixed Colors-Pkt., 10c.

\section{Livingston's Glory of the Garden Mixture}

This is our best mixture of the dwarf varieties. It s composed exclusively of the most elegant, largeflowered sorts, and the brilliantly colored flowers range through every shade and tint known in this favorite annual. This seed will produce a bed or border gorgeous beyond description.

2130 Glory of the Garden Finest Mixed-Large Pkt., 10c.; oz., $20 \mathrm{c}$; $1 / \mathrm{s} 1 \mathrm{~b} ., 65 \mathrm{c}$.

Mired Dwarf Nasturtiums-We handle such large quantities of Dwarf Nasturtiums that we are able to offer this especially choice mixture at a very low price. You should plant this mixture very liberally.

2150 Cholce Mized-Pkt., 5c.; oz., 15c.; 1/4 lb., 40c.

\section{Dwarf Queen Nasturtiums}

A gorgeous mixture of all the dwarf or Tom Thumb varieties of the Marble-leaved Queen Nasturtiums. Containing etreat number of named varieties as well as numerous a grea new hybrids not yet sufficiently "fixed" in color to other new hybrids not yixed-Pkt., $5 \mathrm{c}$.; oz., $25 \mathrm{c}$.

Mrs. J. H. Astle, Rich Co., Utah, writes: "Your Tall or Climbing Nasturtiums cannot be spoken of too highly, for they provided a gorgeous mass of blooms all summer long, with little or no cale. I am sending another order for Flower Seeds, for I believe your seeds are True Blue." 


\section{Nicotiana}

(Sweet-Scented Tobacco Plant)-Handsome and well-known hardy annuals that grow easily from seed, forming compact bushes about 3 feet high, which are in continuous bloom throughout the season. The blooms are tube-shaped, very sweet-scented, and desirable as cut flowers; also fine for pots. 2158 Afnis-A very popular sort; its flowers are pure white and deliciously fragrant. Always in bloom. Pkt., 5c.

2160 Sanderae-This beautiful hybrid Nicotiana form bushy much-branched plants 2 feet high, the whole plant laden with flowers from base to summit-literally ablaze with handsome carmine-red fragrant blossoms, hundreds of which are produced on a single plant. Pkt., 10c.

\section{Nigella (Love-in-A-Mist)}

A very popular, old-fashioned flower; free-flowering, with finely cut foliage surrounding the curious looking flowers and

2163 Mised-Pkt., 5c

\section{Ornamental Grasses}

Effective and attractive for garden borders and ornamental groups. Also extensively used when dried for Winter bouquets.

1660 Coix Lachrymae (Job's Tears)-Beautiful variety. Has corn-like leaves, and hard, glossy gray colored seeds, which naturally have a hole in them like beads, 2 feet. Pkt., $5 \mathrm{c}$. oz., 10c.; 2 ozs., (enough for a chain), 15c.; 1/4 lb., $25 \mathrm{c}$.: lb., $75 \mathrm{c}$

2170 Eulalia Zebrina (Zebra Grass)-The long dark green eaves are beautifully striped with yellowish white. Perennial. feet high. Pkt., 10c.

2172 Mixed-Annual varieties. Pkt., 5c.

\section{Livingston's Mammoth Pansies}

Our Pansy Seeds are grown exclusively for us by the pest American and European Specialists. All our strains are from not fail to give the most unbounded satisfaction to amateur and professional grower alike. Sow in the house, hot-bed, or green house; or as soon as the weather permits, the seed may be sown directly in the garden beds. Pansies thrive best in a rich soil, and cool, moist situation: they do splenpart of each day the most satisfactory result can be obtained. Seed sown from July to September and the strikes only transplanted into cold-frames for the Winter, will bloom grandly very early the following Spring. (Prices by ounce or larger quantities will be quoted upon application.) Free to our customers, leaflet on the culture of Pansies.

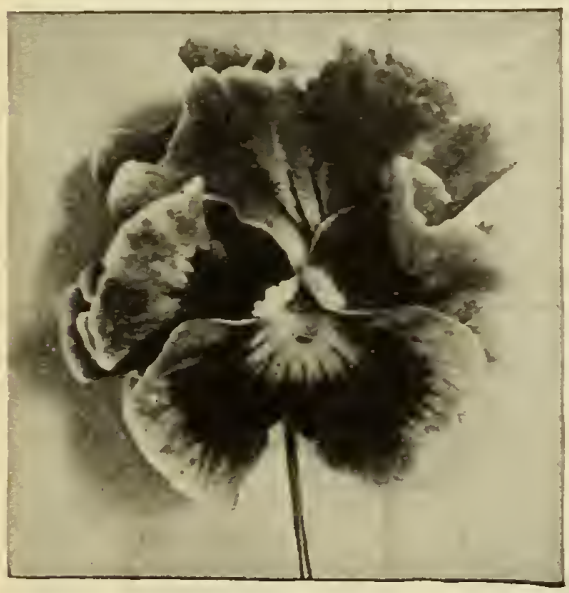

Giant Ruffled Masterpiece

\section{Giant Ruffled Masterpiece}

A remarkable type, the border of each etal being conspicuously curled and undulated, which gives the flower a double, or globular appearance. The large blooms are beautifully blotched. 2181 - Pkt., 15c.; 2 pkts. for $25 \mathrm{c}$

Mr. W. D. Holmes, Fairfield Co., Conn. writes as follows: "I was very well pleased with your Seeds last year. Your method of doing business when you learned that the 'Money Order' which I sent to you had either been lost or stolen from the mail pleased me very much, and while I do not buy a very large amount of Seeds, you may rest assured that any business I can

\section{Exquisite Orchid-Flowered}

All the delicate shades and tints of the Orchids may be found in these charmingly pretty favorites. Rose, orange, pink, lilac, terra cotta, chamois and other exquisite shades are predominant and please all lovers of the delicate by their refined form and texture. Orchid-flowered Pansies are not as large as some of our Giant strains; but they will appeal by their exquisite coloring $10 \mathrm{c}$.

\section{Mammoth Parisian}

The French Pansies are large, and strongly marked and blotched; in a word they are very attractively "Frenchy." The strain we offer is one of great excellence, the individual flowers being superb, and include many fine
shades. 2183-Pkt., 10c.; 3 pkts. for $25 \mathrm{c}$.

\section{Giant German}

The German Pansies are noted for their almost endless varia tions, which include striped. blotched bordered, veined, and marbled combination, in, every possible color and shade. The plants are of compact growth. and uously all summer. 2185-Pkt. $10 \mathrm{c}$ : 3 pkts. for $25 \mathrm{c}$.

\section{Livingston's Giant Mixture}

This splendid mixture is a blended combination of giant-flowering Pansies. ful surprise in res and will prove a delight 2177 Giant Mixture-Pkt., 10c.; 3 pkts. for 25c.; $1 / 8$ OZ., $\$ 1.00$

English Pansies-The old-fashioned "English Face" Pansies. 2191-Pkt., $10 \mathrm{c} . ; 3$ for $25 \mathrm{c}$

David ₹. Wilber, Dutchess Co. $\mathbf{N}$. Y.

"My seeds gave entire satisfaction and several of my neighbors are sending to you for seed after seeing my garden last year." 


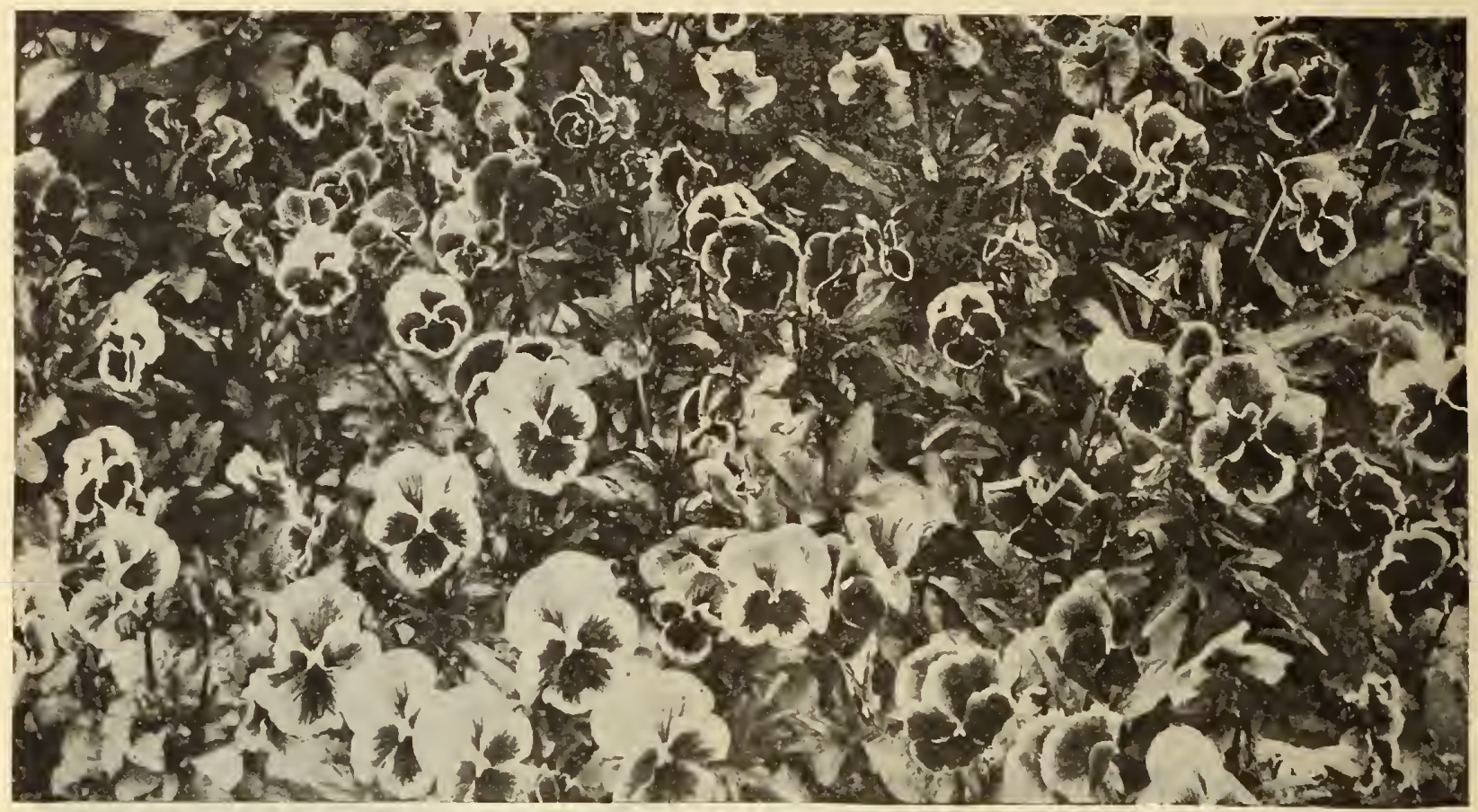

Livingston's Fancy Pansy Mixture

\section{Livingston's Fancy Pansy Mixture}

In this magnificent mixture of mammoth flowering panfoliage and are distinguished for their stems well above the colorings and beautiful markings; of fine substance, velvety texture perfect form and giant size frequently measuring three inches in diameter The colorings are wonderfully rich and varied; every shade and tint of rose, canary-yellow, black, white, cream, lavender, garnet, skyunequaled collection of all the fnest 2175 Fancy Mixture-Pkt.

\section{Giant Trimardeau Separate Colors}

194 Gt. 2194 Gt. Atropur 2196 Gt. Golden Oueen-Pure golden-Pllow: 2196 Gt. Golden Queen-Fure golden-yellow; very fine...10 c. 2198 Gt. Id. Beaconsfleld-Lavender, heliotrope, purple, 10c. 2199 Gt. Peacock (Gloriosa)-Garnet, cream and blue...10 c. 2200 Gt. President Carnot-White, large violet blotches $10 \mathrm{c}$. 2201 Gt. Snowflake-Spotless, snow white.........................10 c.

\section{Giant Trimardeau, Mixed}

These are among the largest flowered of all, a most showy class of robust and very compact growth. Flowers are carried well above the leaves. Mixture of finest
colors. 2205-Pkt., 10c.; 3 pkts., 25c.; $1 / 8$ Oz., $75 \mathrm{c}$.

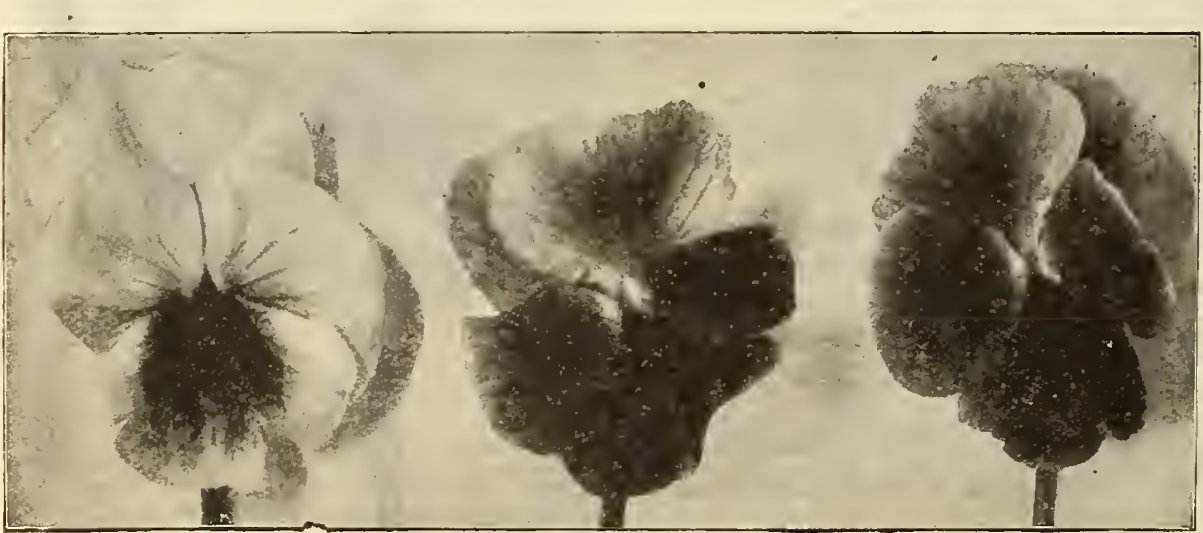

Giant Trimardeau Pansy

\section{Madame Perret}

A splendid giant-flowering strain, which is of French origin. The flowers are produced most freely, and are of the greatest diversity of colors, comprising all shades of red, from lightest rose to darkest purple. Many - are striped. 2189-Pkt., $15 \mathrm{c}$.

\section{Bugnot's Superb Blotched}

The flowers of this splendid strain are of the largest size, and produce the handsomest and richest blotched varieties known in Pansies. We recommend this mixture. 2187 -Pkt., 20c.; 3 pkts. for $50 \mathrm{c}$

\section{Bedding Pansies Mixed}

We have taken much pains in composing this mixture and it will make a rich display. Contains all the fine Bedding Pansies named above. 2225 Mixed-Pkt., 5c.; $1 / 1$ Oz., $50 \mathrm{c}$.; $1 / 2$ Oz., 90c.; Oz., $\$ 1.75$.

\section{Our "Giant Six" Pansy Collection}

This collection contains one packet (100 seeds) each of the following elegant varieties: Giant Red, Giant White, Giant Blue, Giant Purple, Giant Yellow and Giant Black. 6 packages in all for $25 \mathrm{c}$.

\section{Platycodon (Chinese Bell-Flower)}

A splendid,hardy perennial, producing large bell-shaped,

white and blue flowers; very showy.

\section{Pyrethrum}

\section{(Feverfew)}

Most attractively hardy perennials, which have become very popular. Valuable border plants with many each surmounted, with handsome flowers, in the brightest shades of rose, flesh pink. crimson, etc.; in bloom a long time, and are splendid as cut flowers. (See Feverfew.)

2362 Single Hybrids-This mixture contains the very largest flowering and choicest varieties. Pkt., $15 \mathrm{c}$.

2364 Golden Feather (Aureum)-Dwarf growing variety, with bright yellow ings and ribbon work. Usu$3 / 4$ ft. Pkt., 5c.; $1 / 4$ oz., $20 \mathrm{c}$. 


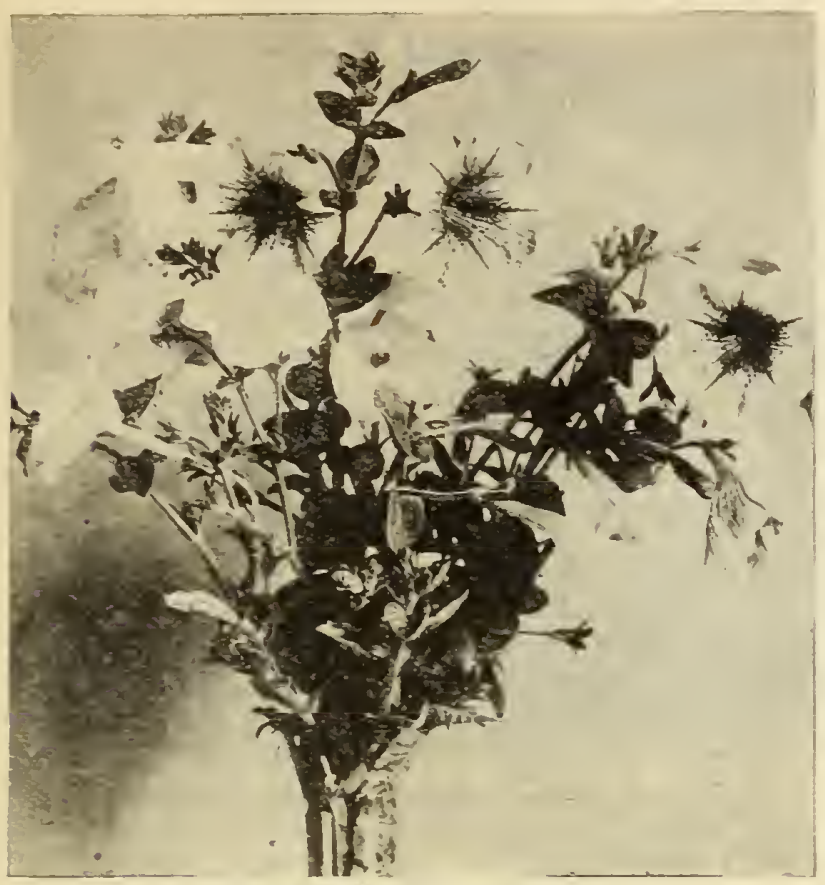

Finest Mixed Petunia

\section{Primulas (Primroses)}

The ease with which Primroses can be grown from seed makes them very popular window plants. For a succession of blooming plants sow the seed from March to May, lightly, and keep moist. Transplant when the second leaf appears, and keep re-potting the plants as they grow and increase in size. Height $1 / 2$ to 1 foot.

2346 Chinese Primrose-Saperb Single Mixed-An elegant mixture, embracing all the best large-flowering varieties, and including the finest fringed sorts. Pkt., $25 \mathrm{c}$.

2348 Chinese Primrose-Superb Double Mixed-Splendid strain of the finest large-flowering, fringed varieties. our mixture includes all the most brilliant colors. Pkt., 25c.

2350 Primrose-Choice Mixed-This is a very choice mixture, and for general purposes will be found most satisfactory. Pkt., $15 \mathrm{c}$.

2352 Obconica Grandiflora-Iarge-Flowering Hybrids -Lovely and profuse blooming Primrose, bearing on long stems large heads of beautiful flowers; white tinged lilac and rose shades; ever-blooming variety with true Primrose fragrance. Pkt., 10c.

2354 Japonica (Japanese Primrose)-Very bright and showy flowers, borne in whorls on stems 6 to 9 inches long. Choicest colors. Pkt., 10c.

\section{Annual Phlox}

For a splendic mass of color and a constant display. the Phlox Drummondii is not excelled by any other annual. It has every desirable quality for this purpose and for beds, edgings and massings nothing can surpass it. Seed may be sown in the open ground any time after danger from frost is past.

2269 Bright Rose-Most pleasing color; a profuse bloomer. Plxt., 5c.; $1 / 1 / 4$ oz., $40 \mathrm{c}$.

2270 Brilliant Scarlet-Is especially showy in large beds or borders. Pkt., 5c.; $1 / 4$ oz., $40 \mathrm{c}$.

2271 Crimson-Popular sort; very brilliant and effective. Pkt., 5c.; $1 / 4$ oz., $40 \mathrm{c}$.

2273 Pure White-Pkt., 5c.; 1/4 oz., 40c.

2274 Yellow-Distinct. Pkt., 5c.; $1 / 4$ oz., 40c.

2267 Prize Mixture of I arge Flowering Phloz-Large Pkt., $10 \mathrm{c}$; $1 / 4$ oz., $45 \mathrm{c}$; $1 / 2$ oz., $80 \mathrm{c}$.

Phlox Druminondil - The old-fashioned favorite variety.

2265 Mized-Pkt., 5c.; $1 / 4$ (oz., 35 c.; $1 / 2$ oz., 65 c.

Star-Shaped Phloz-Long, pointed petals, which give the flowers a star-like appearance; plants grow compact and dwarf. 2278 Mixed-Pkt., 5c.; 1/8 0z., 30c.

\section{Petunias}

Petunias are one of the most popular annuals on account of their ease of cultiration and freedom of blooming, succeeding everywhere and giving a constant suppiy of flowers from June to October. They are also good house plants, flowering freely in a sunny window. Seed can be sown in the open ground early in the Spring ${ }^{\circ}$
in a hot bed or cold frame, to be transplanted later to in a hot bed or cold frame, to be tra
beds or borders. Height 1 to $11 / 2$ feet.

\section{Large-Flowering Petunias}

The blooms are enormous in size and of the richest colors and markings. Varieties listed below are unsurassed.

2240 Livingston's Superb Single Mixed-1 strain of incomparable beauty and luxuriance. Flowers most varied in colors and markings: beautifully ruffled, fringed and of enormous size. Plit., 15c.; 2 pkts. for $25 \mathrm{c}$.

2244 Ruffled Giants-The flowers of this strain are of extraordinary size and great substance: the edges of the blooms ruffled. Contains the greatest variety of rare colors and combinations.

2242 Giants of California-These Petunias are of great beaut and luxuriance, including fringed and deepthroated sorts in endless variety of colors, veinings and markings. Flowers of enormous size. Pkt., $15 \mathrm{c}$; 2 pkts. for $25 \mathrm{c}$

2246 Livingston's Superb Double Mixed-Our best mixture of all the large flowering double varieties, including striped, blotched and fringed sorts. Pkt., 25c.

\section{Bedding Petunias}

2250 Howard's Star-Shaped-Entirely distinct. The markings of blush2254 snowball-A charming, compact-growing variety inches and yields in greatest profusion all season its pure satiny-white flowers. Pkt., $10 \mathrm{c}$.

2256 Striped and Blotched-A most beautiful strain of Petunias for bedding and massing. Our mixture contains an endless variety of colors. Pht., 5c.; $1 / 8$ oz., $40 \mathrm{c}$.

2258 Finest Mixed-A choice mixture of colors and shades: will make a fine display in your garden. Pkt.,

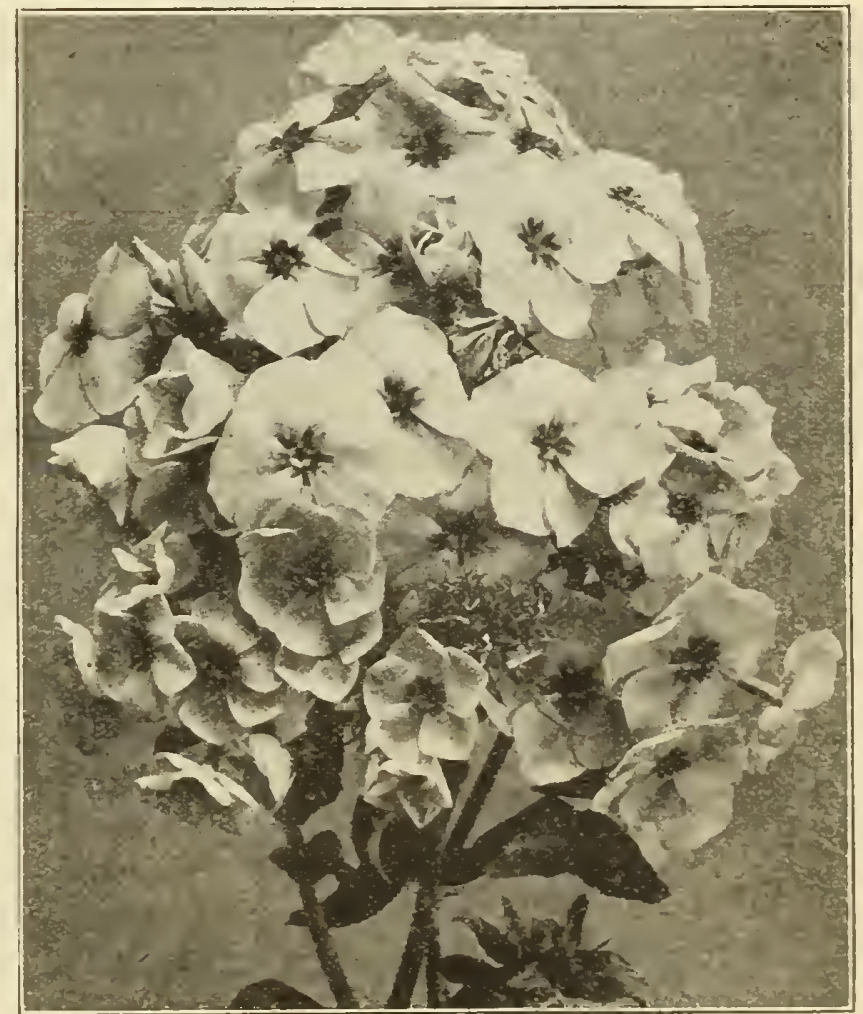

Annual Phlox 


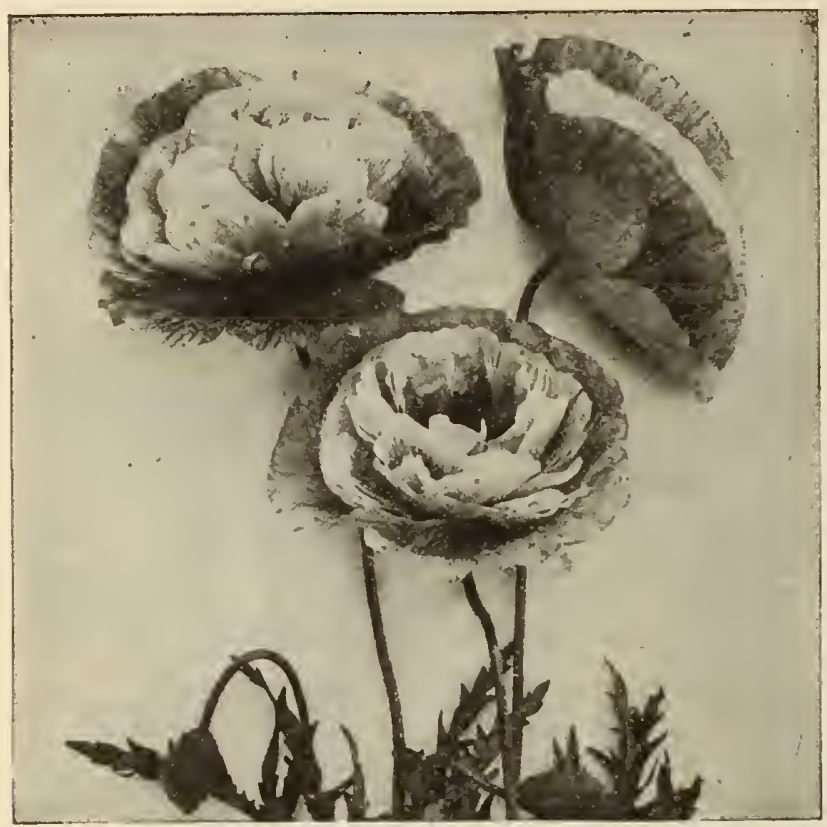

Double Annual Poppies

\section{Poppies}

The recent development of these old-fashioned flowers has brought them into great and deserved popularity. No flower in our garden affords a more pleasing display of gorgeously brilliant colorings during the blooming season. Poppies of the vari
height, except as noted.

\section{Double Annual Poppies}

2300 Paeony Flowered-Large, showy double globular flowers; almost equal to Paeonies. Our mixture contains the finest colors. Pkt., 5c.; $1 / 2$ oz., $15 \mathrm{c}$.; Oz., $25 \mathrm{c}$.

2302 White Swan-Pure snow white, double and large size. Beautifully fringed. Pkt., 5c.

2306 Fairy Blush-Immense flowers, perfectly double, 5 inches across; elegantly fringed; pure white, rose-tipped petals. Pkt., 5c. 2308 Carmation Flowered-Splendid large double flowers; showy and beautifully fringed. Mixture is unequaled for dazzling richness and great variety of colors. Pkt., $5 \mathrm{c}$.: $1 / 2 \mathrm{Oz}$., $15 \mathrm{c}$; ; oz., $25 \mathrm{c}$

2310 "Mixado" (The Striped Japanese Poppy)-Very distinct and beautiful; the large blooms are brilliant scarlet and white, with elegantly curved and fringed petals. Pkt., 5c.; 1/4 oz., $10 \mathrm{c}$

Iivingston's Giant Double Mixed-A mixture of beautiful double Poppies, including only the improved double, giant-flowering kinds of the richest and brightest colors, as well as the daintiest and softest tints. When grown in masses it is brilliant beyond description. The plants are sturdy, thrifty growers, from 2 to 3 feet high, producing immense flowers, sometimes 4 inches in diameter. Sow the eds in the early Spring in sandy soil where they are to remain.
2311 Mixed-Pkt., 5c.: oz., 35c.

\section{Single Annual Poppies}

2316 Ifivingston's Giant Shirley-These are considered by many the most charming Poppies in cultivation. The individual flowers are large and elegant, mostly single blooms, some semi-double and double ones, often measuring from 3 to 4 inches across. The petals are fluted and crinkled and in the sun appear like crumpled satin. The exquisite colors range from purest white to the deepest of blood-red, through all the shades and combinations of pink, rose, blood-red, through all the shades and combinations
crimson and carmine. Pkt., 5c.;1/4 oz., 20c.; oz., $60 \mathrm{c}$.

2321 Danebrog (Danish Cross)-A very showy single variety; brilliant scarlet, blotched with silvery gray. Pkt., 5c.

2323 Tulip Popples-Large and splendid single fiowers of the most dazzling scarlet. The two outer petals resemble a saucer, in which are set two erect petals of the same color. Pkt., 5c.; $1 / 4$ oz., $20 c$. 2325 New Admiral-Of surprising beauty. Large, round, smooth edged flowers of glistening pure white, with a broad band of brilliant scarlet around the top. " Pkt., 10c.

Mrs. H. N. Chapman, Shelby Co., Ohio, writes: "I have used the Livingston Seeds for. years and I would be afraid to use any other now. I used to have very poor gardens, but now I raise as fine stuff as any one for miles around, so I find it is in the seed, not in the person. I will try to get as many friends to send when I send as I can."

Miss Anna IM. Farrell, Buchanan Co., Iowa, writes: "This is the third season I have ordered Pansy Seed from you. Always have fine success with your seed."

\section{Perennial Poppies}

There are no flowers more ornamental and useful in our ens than the various varieties of hardy Poppies. started they increase in size and beauty each suc-

2334 New white Oriental-It is the most distinct

"Break" "that has yet been made in Oriental Poppies, it 列 dition to the list of hardy perennial seeds. Like most brids the seedlings are liable to vary somewhat in come true. Pkt., 20c.

333 Iarge Oriental-Perhaps the most popular variety cultivation, the sturdy plants growing about 3 feet Its color, a dazzling scarlet with coal-black blotches ectly hardy plants. Pkt., $10 \mathrm{c}$.; $1 / 8 \mathrm{Oz}$., 35c.; 1/4 0z., 50c

335 Oriental Fybrids-Splendid hybrids of Oriental Enormous flowers, sometimes more than six

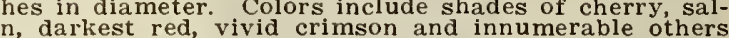
fine. Our mixture contains them all. Pkt., 10c. $45 \mathrm{c} . ; 1 / 4$ oz., $60 \mathrm{c}$

330 Iceland (Papaver Nudicaule)-These Poppies are frectly hardy and in bloom from June until frost; beauul satin-like flowers, of every shade of yellow, white ming tufts, from which the flower stems issue most Very useful for cut flowers, Easy to grow. $10 \mathrm{c}$; $1 / 8$ oz., 20c.

332 Double Mixed Iceland-This splendid mixture of able-flowering varieties you will find very superior.

\section{Portulaca (Sun Plant)}

ould be sown in every garden. Scarcely any annual of highly colored, many-hued Portulacas. Plant a randy soil, soon as it becomes warm, with full ex-

arge-Flowering Single Mixed-A most elegant mixture;

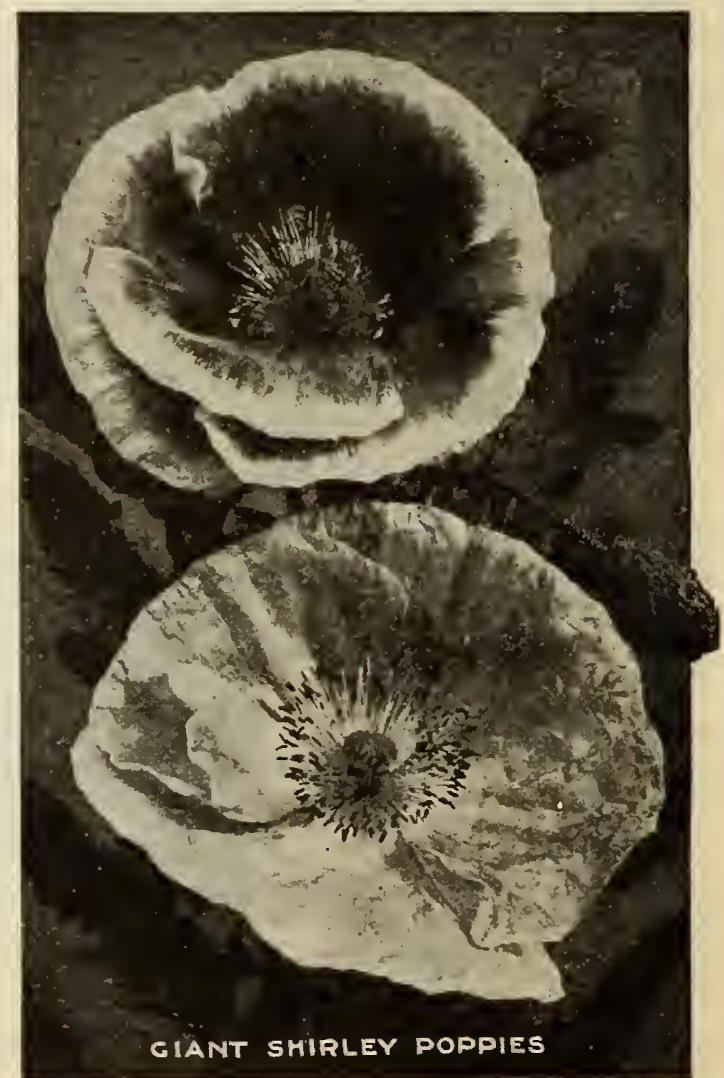




\section{Ricinus}

\section{(Castor Oil Bean)}

2370 zanzibariensis-A new and distinct class, surpassing in size and beauty all varieties hitherto known. Plants attain great dimensions-12 to 2371 Borboniensis - Very large and most showy green to $15 \mathrm{ft}$. Plt., 5c.; oz., $20 \mathrm{c}$.

2372 Cambodgensis - Main stem and leaf stalks shining ebony black; leaves large and brilliantly colored. Foliage assumes various sh
Prt., 5c.; 0z., 20c.

2373 Gibsoni - Compact growing variety of branching trabit. The large leares are a deep red.

2377 Iivingston's Ricinus Mixture - Appreciating fully the splendid effects tnat a fine array of these desirable foligarden, we hare composed a mixture that for elegant blending is unsurpassed. Prt., 5c.; Oz., 15c.; $1 / 4$ 1b. $50 \mathrm{c}$.

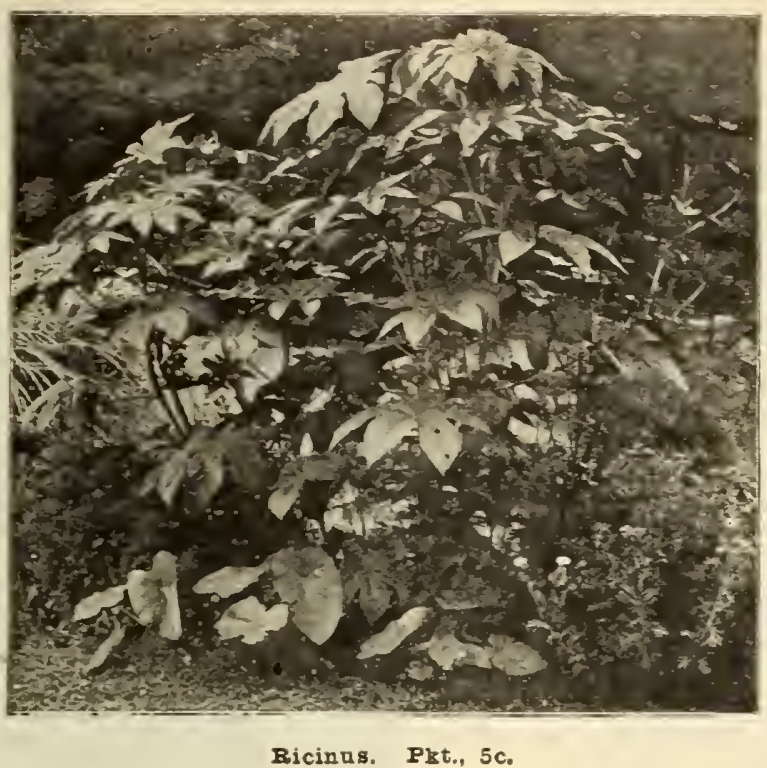

\section{Roses}

(Bloom the First Year from 2380 Baby Roses, also called Dwarf Midget, or Pairy Roses - These beautiful little roses are borne in many flower clus ters of double, semi-double and the tints of other roses. Seed should be soaked in warm blooming year after year. Pkt. (50 seeảs), 10c.; 3 pkts., $25 \mathrm{c}$

\section{Salpiglossis}

(Painted Tongue)

The Salpiglossis is one of the most popular and favorite culture. Especially is it noted for its beautiful, almost orchid-like blooms. (See illustration below:) Our mixture every desirable color and shade of the large-flowering variPlkt.., 5c.

\section{Salvia (Flowering Sage)}

Very ornamental plants, for summer and Autumn flowering bloom in spikes, and continuing to bloom in the open ground until hard frosts, forming compact bushes, which be started in a box in the house or in the hotbed, and when the weather becomes warm transplant in the garden. Height 2 to 3 feet. (See illustration.) May be used as a hedge with striking effect.

2384 Splendens Grandiflora (Scarlet Sage) - Gorgeous plants, numerous spikes of intensely vivid scarlet flowers 10 to 12 inches in length. Continues to flower profuselyo Salvia in cultivation. Pkt., 10c.; 1/s 0z., 60c.

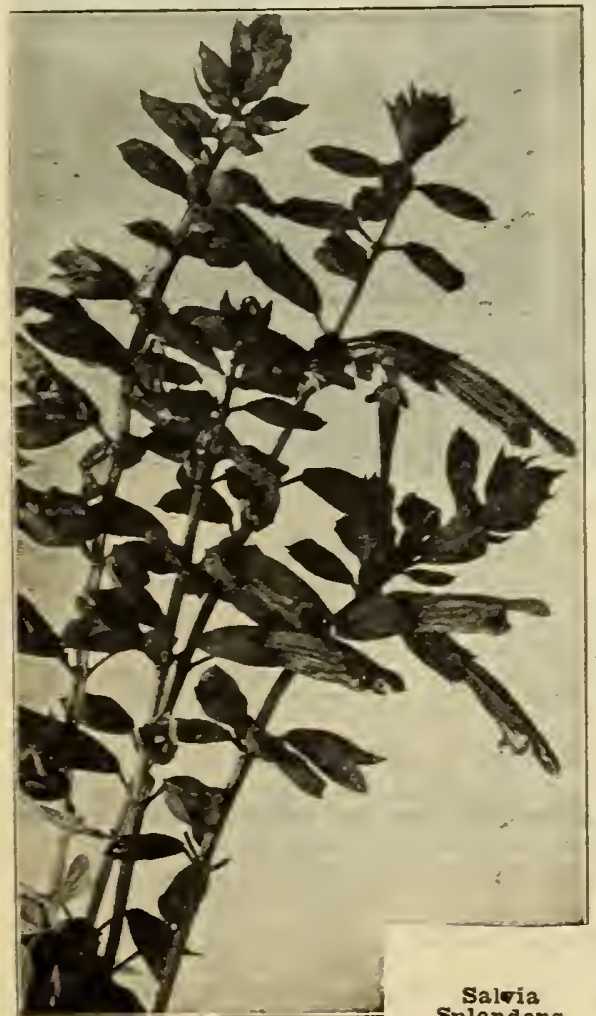

Splendens 18 oz., $75 \mathrm{c}$.

2388 Silverspot-Strikingly handsome spotted foliage. Leaves rich, soft, dark green, with light yellowish spots of various size sprinkled over them, and have a fresh. healthy appearance. Flowers are large, bright red; plants of neat, compact habit. Pkt., 10c.

2390 Scarlet Dragon-A magnificent free-growing new variety, forming dense, bushy plants 3 feet high; with moth spikes of vivid carmine scarlet flowers of extra large way's in bloom and vividly gay, Pkt., $10 \mathrm{c}$.

2386 Bonfire-Plants form healthy bushes 2 feet across. Spikes grow erect and stand clear above the foliage, completely covering the plant, and liant, dazzling scarlet. One of the finest sorts. Pkt., 10c.;

2398 Zurich-Compact growing sort, forming handsome, symmetrical bushes. 15 to 18 inches tall which are completely covered with scarlet lower spikes.

\section{Ostrich Plume}

2385-This new variety is the most of recent introduction. Its habit of grow th resembles that of the Splendens Plume quite similar in form to Ostrich Plume Celosia. One Plume alone is a bouquet itself quite a per cent of the howers are double and this is the only ent time that is somewhat different from all other Salvias, being of a rich, glossy, dark scarlet.
Pkt., 15c.; 1/8 oz., 75c.

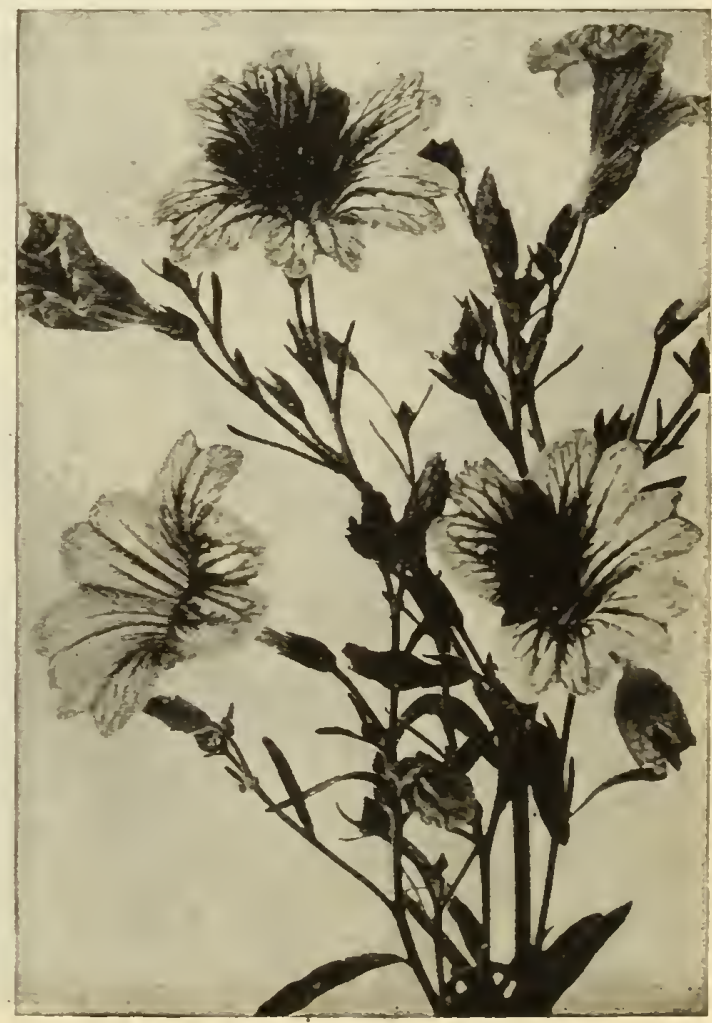

Salpiglossis, or Painted Tongue 


\section{Scabiosa}

(Sweet Scabioga, Mourning Bride, Pin-Cushion Flower, Egyptian Rose, Etc.) - The seed can be sown any time in the Spring after danger from frost is past. The plants grow about $21 / 2$ feet high, and come into hloom early in June, continuing without interruption until the hard frosts of Autumn. 'The exquisite double flowers (see illustration) are borne on very long stems, and when cut keep in perfect condition for the best part of a weel:

2404 Livingston's Improved Iarge-Flowering Scabiosas, Finest Mixed Colors -A very fine mixture, containing all the finest large-flowering double sorts. All colors. Pkt., 5c.

2406 Azure Fairy - Exquisite 2408 Fiery Red-Very striking: double: fiery scarlet. Pkt., 5c. 2410 violet-Very
very dark. Pkt., $5 \mathrm{c}$.

2412 Snowbail-Double white flowers; fine for bouquets. Pkt., $5 \mathrm{c}$.

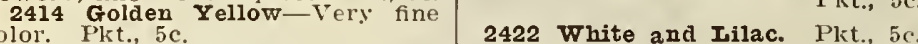

2416 Pompadour - Claret-purple edged white. Plit., $5 \mathrm{c}$ 2418 Flesh.

2419 Carmine Pink.

2420 Iilac.

2421 Plit., 5 c.

Collction Scabiosa, above 11 separate colors, 50c.

2426 Hardy Scabiosa Caucasica-Grand hardy perennial, 3 feet high; large lilac-blue flowers; splendid for cut flowers. Pkt., 10c.

\section{Schizanthus or Butterfly Flower}

Popularly called the "Poor Mran's Orchid." It grows from a foot to 18 inches tall, with fine fern-like foliage, begins to flower early: and produces masses of oddly marked and queerly shaped blooms in various shades of blue, purple and pink and some pure white.

2427 Schizanthus Mixed-5c. per packet.

\section{Scarlet Runner-Bean}

Ornamental climber. Bright scarlet sprays of bloom, follower hy edible beans.

\section{Sunflower (Helianthus)}

A well-known family of hardy annual, very showy plants, large flowers 2454 New Miniature-Beautiful new hybrids; small single flowers, in great abundance: colors, creamy white, lemon and orange; indispensabl for cutting. Pkt., 5c.; $1 / 4$ oz., $20 \mathrm{c}$.

2456 Globe of Gold-Globe-shaned, double yellow flowers. Pkt., 5c.

2460 Livingston's Mixed Sunflowers A great variety of single and double varieties. Every shade of yellow is included. Plkt., $5 c_{.} ; 1 / 20 z ., 15 \mathrm{c}$; ; oz., $25 \mathrm{c}$.

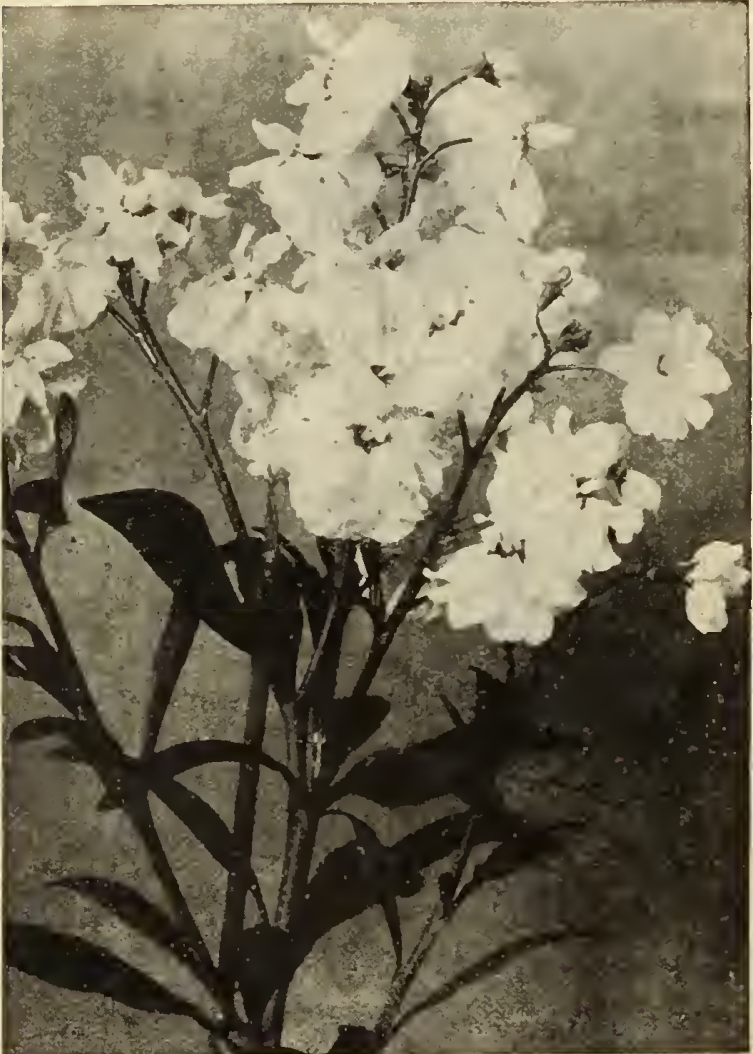

Ten-Weelr-Stock Snow White, Pkt., 10c.

\section{Sensitive Plant}

A pretty and curious annual plant the leaves and footdroop at the slight est touch, or in cloudy, damp weather. $11 / 2$ feet. 2430 -Plit., 5c.

\section{Smilax}

Charming tender perennial c l i m be for house or greenhouse. $2435-$ Pkt.

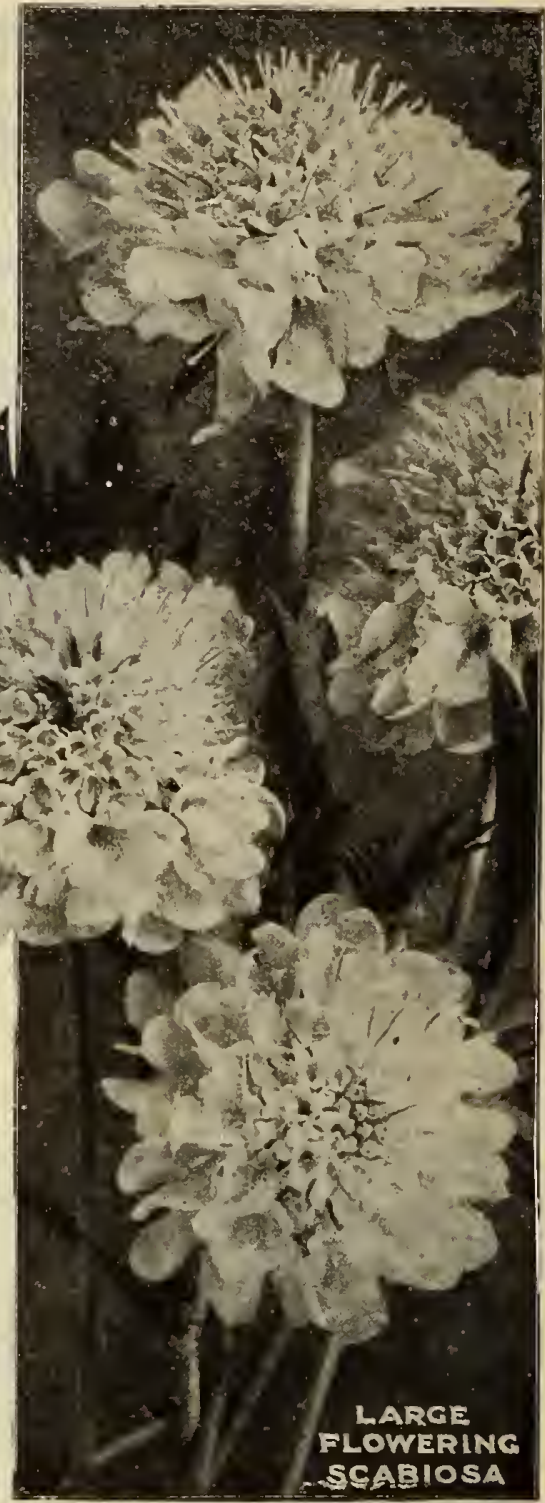

\section{Stokesia Cyanea}

(Cornflower Aster)-A valuable hardy perennial bedding plant. Plants large, 18 to 20 inches high, with Bachelor's Button-like light lavender-blue flowers, which are several inches in diameter. Are produced from July until late in October. Very easily grown in almost any situation. 2436-Plit., 10c.

\section{Shasta Daisies}

A hardy perennial plant; blooms more abundantly each season; multiplied by division of roots or sowing seed. They bloom for several months in great abundance. The flowers are large and graceful, with three or more rows of pure white retals. 2433 Selected seed-Much superior to original strain.

\section{Stocks (Gilliflower)}

Indispensable for bedding, borders, massing or pot culture. Large-Flowering Double "Cut and Come Agaln" Varleties. 2446 snow white-(See illustration.) Pkt., 10c.

2440 Finest Mixed-This is our very best mixture of largeflowering stocks. The perfectly double flowers embrace every color and shade. Pkt., 10c.

2448 Giant Perfection Stocks-Long spikes of double flowers.

2450 Fine Mixed Stocks-A choice mixture of various colors and shades. Pkt., 5c. 


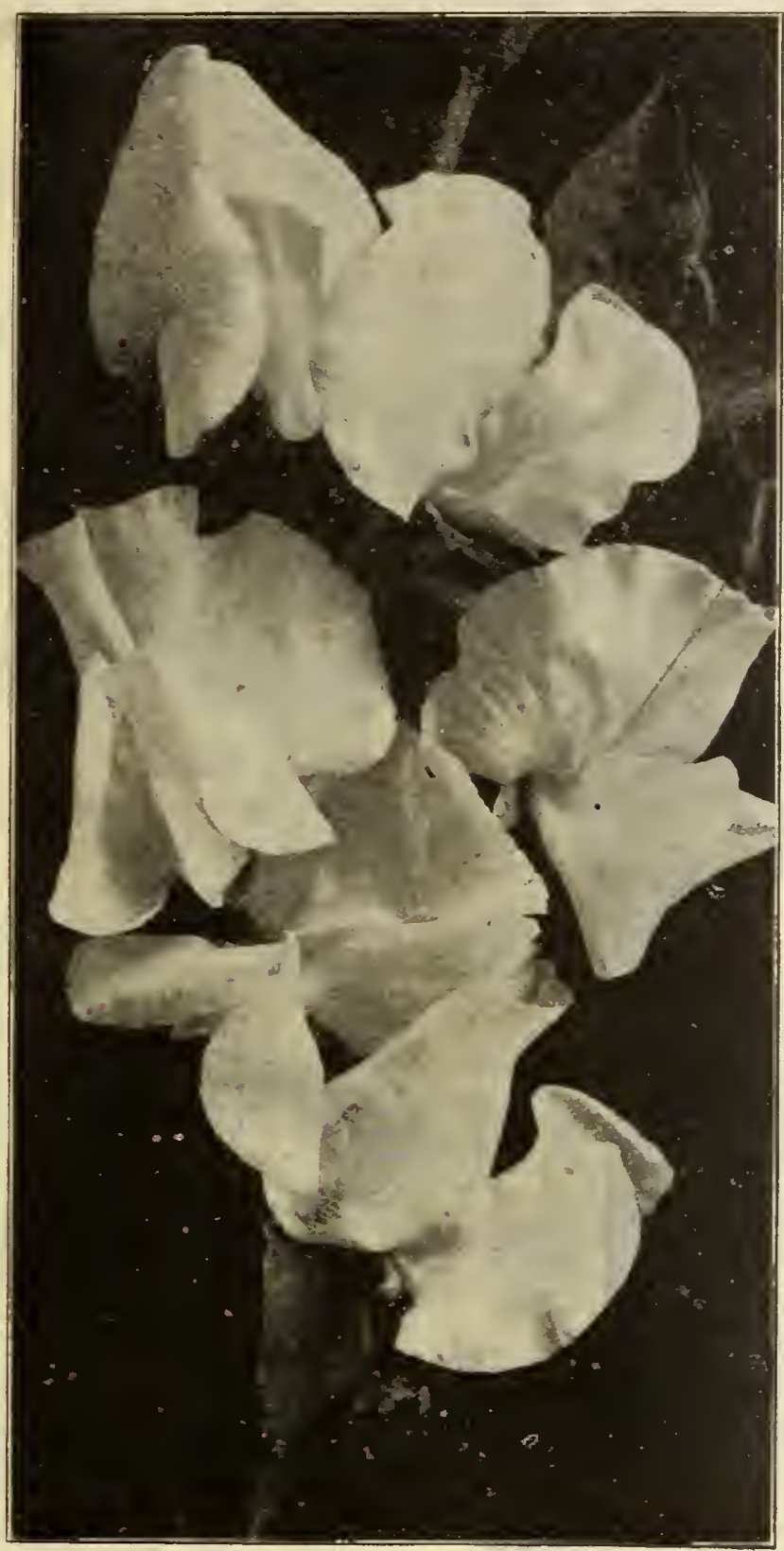

White Spencer

\section{Spencer Sweet Peas}

How to Grow Fine Sweet Peas-The general opinion is that Sweet Peas being common and hardy can be planted anywhere, which accounts for a lot of failures. There is no reason why everyone, should not have fine flowers plant early, just as soon as the ground can be $d u g$ and is not sticky. Dig deeply. If you are growing sweet peas every year, try and.plepare your ground in the Fall, and dig 18 inches deep, mixing manure thoroughly in the subsoil The surface soil in which the seed is sown should not contain manule if you start in the Fall you x.ill find you can sow earlier in the Spring. If you can't secure manure, use bone meal or commercial fertilizers containing phosphate and potash. Cover the ground an eighth of an inch with these and then dig in and mix thoroughly with the soil. Sow the seed three inches deep if on sandy soil, or two if in clay. Sow thinly unless you have the courage to pull them out after they come up. You can't have fine flowers through the season when plants are very thick. Two or three inches apart, or better, four inches if you want big flowers. Cultivate as soon as they are up and keep cultivating. Stake them as soon as the rows show plainly. For the first month they scarcely make any growth above ground, but don't need water unless the season is very dry. Later on, when they are showing vigorous growth, a thorough watering twice a week will help wonderfully, if there is not sufficient rain. Don't plant them alongside a house, under trees or close to a board fence and expect much from them. They need an open space.

\section{King White}

2626 - Undoubtedly the best white now in cultivation. $t$ is remarlkable for the "glistening inımaculate purity of the whiteness" and the perfect finish of the flower. While of truly gigantic proportions, the flowers are most exquisitely finished in every detail. The grand flowers are borne almost invariable in "fours" upon stout stems of great length. Pkt., $15 \mathrm{c} . ; 0 z ., 40 \mathrm{c}$.

\section{Illuminator}

2627-It might be described as a rich glowing cerisesalmon. With an indication of bright orange suffusion. The flowers are most perfectly formed and well placed on long stout stems, frequently in "fours." Pkt., 15c.; oz., $40 \mathrm{c}$.

\section{Margaret Atlee}

2625-Margaret Atlee is a rosy salmon-pink on cleamy buff ground: a rich, soft color, and extremely at tractive, both as individual flowers and in the bunch The standard is large and wavy and inclined to double It runs almost uniformly four blossoms to the stem; well poised and graceful. Pkt., 15c.; 0z., 40c.

\section{Fiery Cross}

2619 - A variety of recent introduction which is one of the most promising of the Spencer type. The standards are fiery red with wings of cherry red. Very large. Does not burn even in the hottest weather. Pkt., $15 \mathrm{c}$. $0 \% ., 50 c$

\section{Wedgewood}

2628-Wecigewood is a unique shade of lovely light blue. The flowers, of good size and substance, are well waved in both standard and wings; they are borne almost uniformly in four-flowered sprays upon long stout stems. Pkt., 15c.; oz., 50c.

\section{This Great Collection of Superb Spencer Sweet Peas-Seven Liberal Packets for 25 Cents Postpaid}

Astha Ohn Spencer-Finest lavender Snencer Sweet Pea 3 to 4 enormous flowers. Wings carmine-scarlet, reverse grown. Comes remarkably true to spencer sweet 3 to 4 enormine The beautiful blossoms are carried elegant, bold, wavy flowers in greatest profusing. 2584kt., 10c.; Oz., $25 \mathrm{c}$

long, stiff stems, 2583-Pkt., 10c.; $0 \%, 25 \mathrm{c}$

Countess spencer-of perfect form, remarkable size and exquisite color. The flowers are often $1 \frac{1}{2}$ to 2 inches in diameter, with both standard and wings charmingly waved and fluted. The coloring is an exquisite soft rose-pink, daintily tinted with silvery white. $2570-$ Pkt., 10c.; $0 z$., $25 \mathrm{c}$

Helen Iewis Spencer-This superb variety is a grand gigantic orchid-flowering seedling of Countess Spencel. The orange-rose wings roll and fold: the standard is reflexed and is of an intense rich crimson-orange. 2580Plit., 10c.; 0z., 25c.

Herbert C. White, Norfolk Co., Mass., writes: "The Sweet Pea Seed I had from you last year was fine and I want to try some of your tomato this year, and other things as well." 


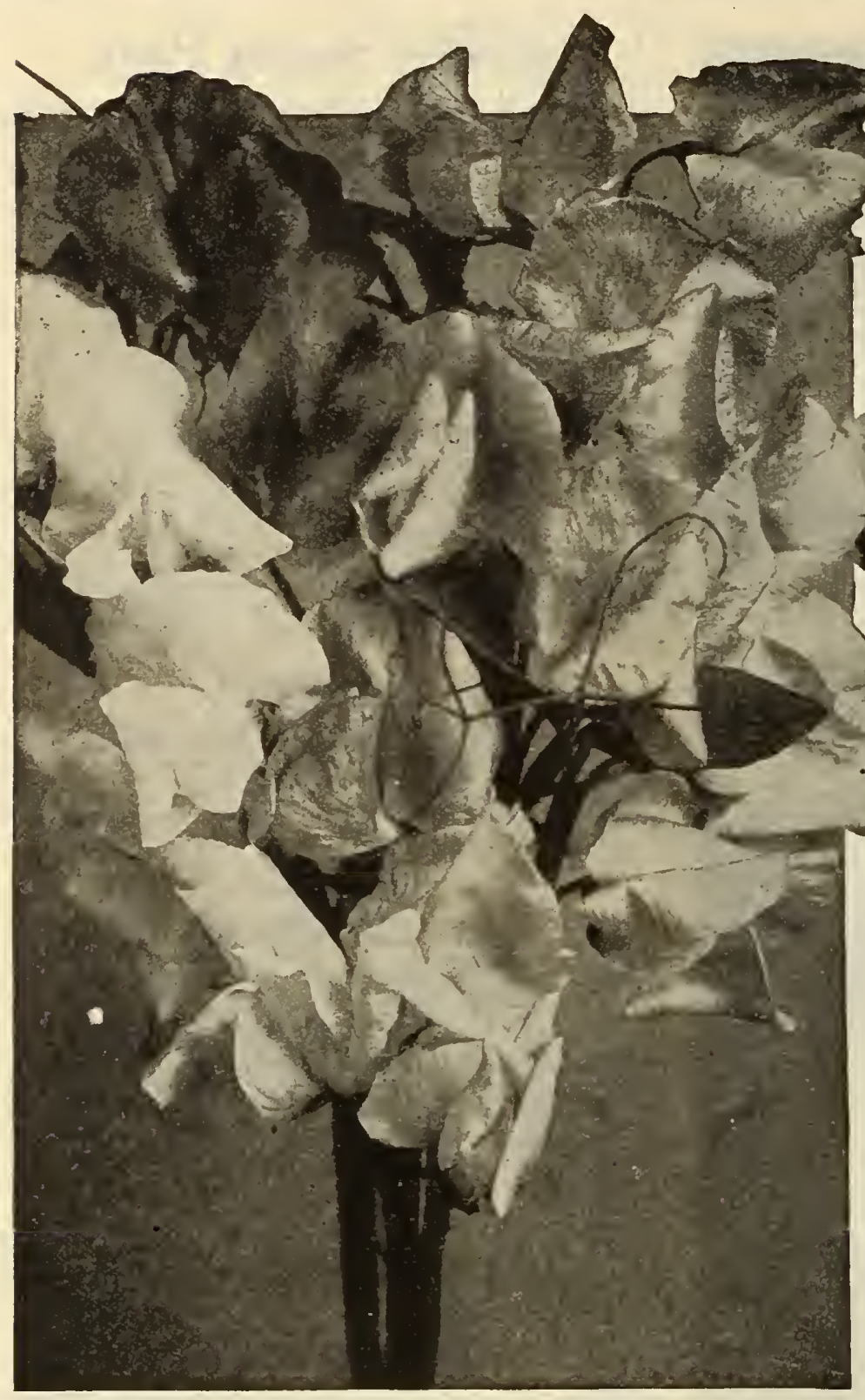

\section{Spencer Sweet Peas} (Continued)

\section{Blanche Ferry Spencer}

The popular old "painted lady" pink and white Sweet Pea in magnificent new form. 2591-Pkt., 10c.; Oz., 25c.

\section{Mrs. Routzahn Spencer}

May be described as buff or apricot, suffused with delicate pink which deepens to a rose near edges of wings to a stem. 2613-Pkt., 10c.; to ${ }^{2}, 25 \mathrm{c}$.

\section{Senator Spencer}

The combination of color in the flowers is charminga deep claret or chocolate, striped and flaked on "a ground of light heliotrope.

Both standard and wings are extra large, wavy and drooping. Flowers are usually borne four to the stem. 2621-Pkt., 10c.; oz., 25c.

\section{Dainty Spencer}

White, with exquisite rose-pink edges, of uniformly large size and elegant shape. 2615-Pkt., 10c.; Oz., $25 \mathrm{c}$.

\section{Aurora Spencer}

Very" large and of true "Spencer" type. The ground color is creamy white, which is finely flaked and mottled with orange-salmon. 2622 -Pkt., 10c.; oz., $25 \mathrm{c}$.

\section{Beatrice Spencer}

White, tinted with soft pink and buff on standard, while the wings have prominent blotches, of a brighter pink near base. . 2614 Pkt., 10c.; oz., 25c.

\section{Primrose Spencer}

Both standard and wings are of beautiful, soft Primrose or creamy yellow color. Flowers are very substantial and in a class of their own in both color and size. 2610-Pkt., 10c. oz., $25 \mathrm{c}$.

\section{Spencer Seedlings Mixed}

All of the best-named sorts, also many rare new hybrids in lavender, blue, striped, mottled, purple, maroon and many other shades are included in this superb mixture. All flowers are of extremely large size, typically frilled and waved, and very lovely. 2630-Pkt., 10c.; oz.,

Spercer Seedlings Mixed $25 \mathrm{c}$.

\section{Eight Best Grandiflora or Large Flowering Varieties for Only 25 Cents, Postpaid}

The greatest bargain in "Grandiflora" Sweet Peas on record. Full-sized packets, finest sorts, lowest price consistent with top-notch quality. Order today-before you forget where you saw this offer.

2467 Dorothy Eckford-An exceptionally fine white variety as popular as the new "Spencer" type on account of its beautiful hooded flowers, borne three and even four on very long stems, making it of exceptional value to the florist.

2530 Eomolo Piazzani-A grand blue Sweet Pea. The color is almost a true violet-blue self; the standard is only slightly hooded; grand flowers.

2484 Blanche Ferry-The popular pink and white; always reliable.
2499 King Edward VIr.-The largest and best bright crimson scarlet.

2474 Mrs. Colller-Flowers are extra large, coming in threes and fours on a long stiff stem and of a rich primrose tint, entirely free from any trace of pink. Richer in coloring than any other primrose variety. "Can be described as a primrose Dorothy Eckford.

2488 Prima Donna-Lovely soft pink, hooded form, vigorous grower.

2505 America-Brightest blood-red striped, on white ground, superb.

2515 Lady Grisel Familton-Beautiful silvery lavender. 


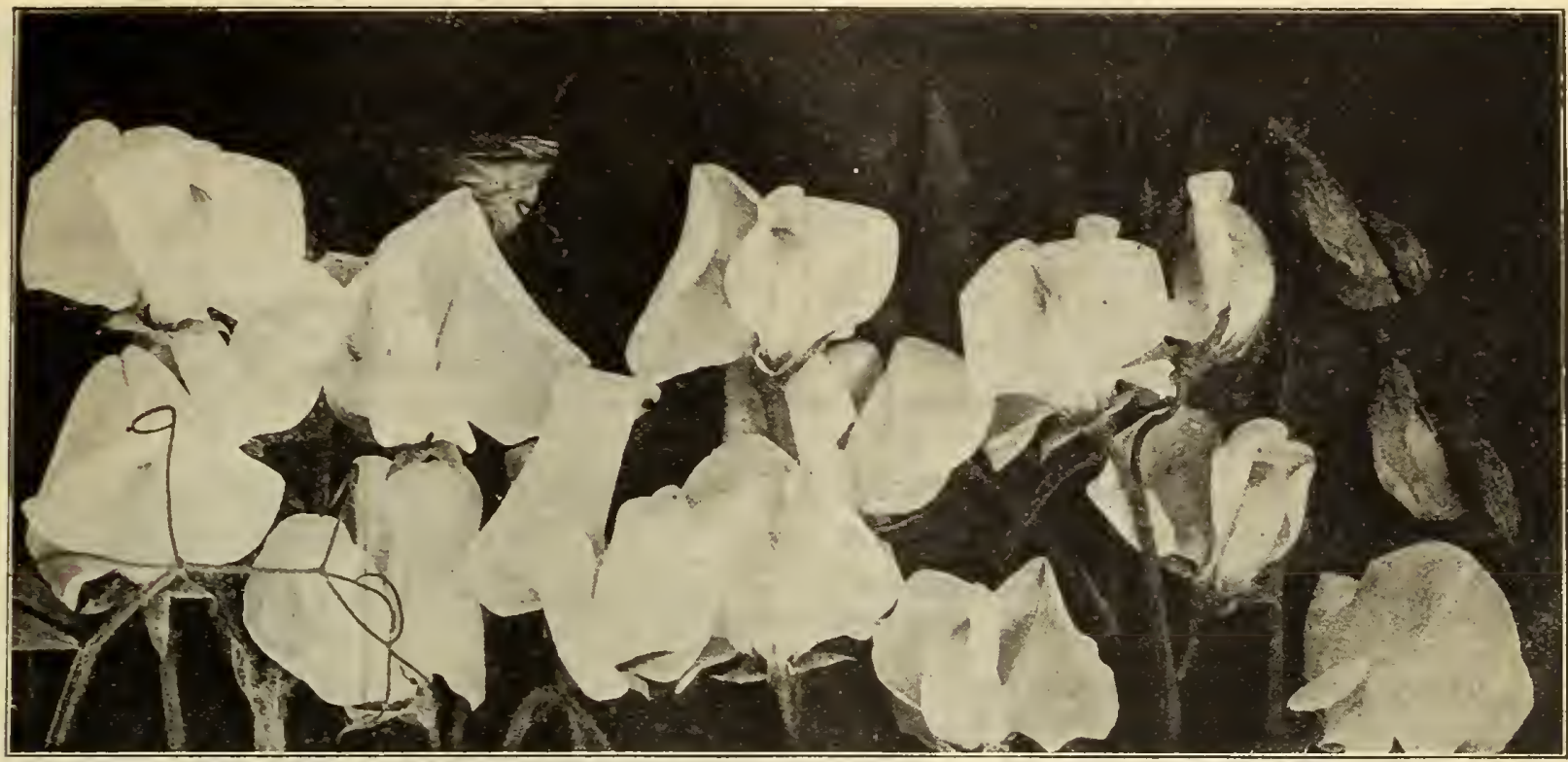

\section{All the Best Named Grandiflora Sweet Peas}

The varieties listed below are the cream of all known sorts. Only those are included in our collection which roduce flowers of the finest form and largest size. Every shade and olor amongst Sweet Peas will be found. All nferior varieties have been discarded.

For the convenience of our customers we have arranged he varieties in tables according to color.

\section{Prices for Any Sweet Peas Named Below}

FREE-If requested with order, our pamphlet of culural directions telling How to Grow Perfect Sweet Peas.

5c per packet-Enough for a single row 5 feet long. Any six packets for $25 \mathrm{c}$.

5c. per oz.-Enough for a single row 15 feet long.

10c. per $1 / 4 \mathrm{lb}$.-Enough for a 60 -foot row.

\section{Blush and Light Pink}

2478 Dainty-Crystal-white, with pink flush, deepening to a pink edge.

2479 Jennie Gordon-Standard bright rose, shaded cream wings creamy, suffused rose.

2480 Iovely-Soft shell pink; exquisite shade; large size.

\section{Pink and White}

2484 Blanche Ferry-The popular pink and white; always reliable.

\section{Rose and Pink}

2488 Prima Donna-Lovely soft pink; hooded form; vigorous grower.

2489 Prince of Wales-Very elegant rich carmine rose; grand flower.

\section{White}

2466 Blanche Burpeo-Large; pure white; ine form; grand flower.

2467 Dorothy Eckford-A grand white, The stems are extra long and stiff and usually carry three flowers of grand size, substance and form. tration.)

2468 Emily Henderson - Large, pure, white, profuse, early and continuous flowering.

\section{Jreamy and Yellow Primrose}

2473 Hon. Mrs. E. Kenyon-The most desirable of all Primrose Sweet Peas. Grand, large flowers, splendid form.

2474 Mrs. Collier-Flowers are extra large, coming in threes and fours on a long. stiff stem and of a rich primrose tirt, entirely free from any trace of pink. Richer in coloring than any other primrose variety. Can be described as a primrose Dorothy Eckford.

Ander Sidders, Iogan Co., Onio, writes: "Last year I bought 8 packages of Swee Peas. They were the Spencer type, 8 pack ages for 25 cents, and I heard people say they were the most beautiful they had ever seen either on the inside or outside of a green house. I wish everyone would try that collection."

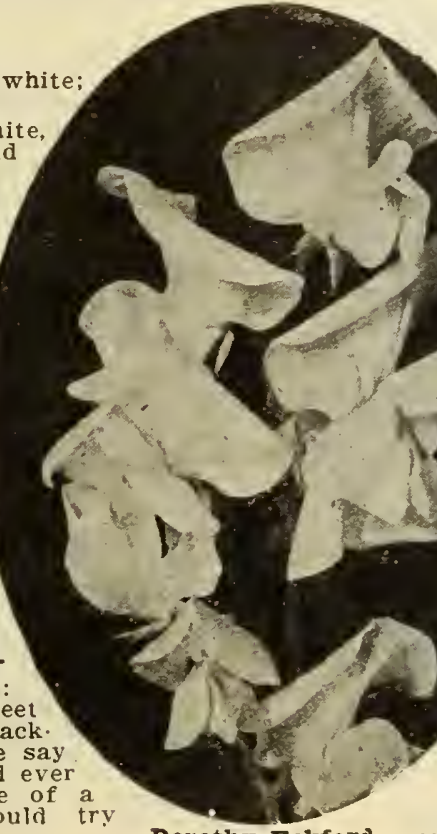

\section{Maroon}

2495 Black knight-A very rich, dark maroon, veined black; the darkest of all.

\section{Red and Scarlet}

2499 ring Fdward VII.-The largest and best bright crimson-scarlet.

2301 Salopion-Rich, deep crimson-red enormous flower; elegant sort.

2500 Queen Alexandra-An intense scarlet sort, with bold expanded flowers of finest form. It is very freeflowering, with long, strong stems. The flowers do not burn in the sun.

\section{Blue}

2530 Romolo Plazzani-A grand blue Sweet Pea. Color is almost a true violet-blue; standard slightly hooded; grand flowers.

From C. M. Taylor, Wicomico Co. Ma.: "I am sending you the names of five persons. I think if they ever use any of your True blue seeds they will not want any other."

Miss J. C. Burgen, Erie Co. N. Y. writes: "Regarding a small sample of Sweet Peas which you sent me this Spring, I want to say they are the handsomest Sweet Peas I ever saw. The red, white and pink ones blossomed nearly all double with three flowers on nearly every stem wo one has anthing like them that $I$ heve Dorothy Eckford 


\section{Named Grandiflora Sweet Peas (Continued)}

\section{Lavender and Light Blue}

2513 Admiration-A grand large flower of be:utiful form, elf-colored in a delacate shade of rosy lavender.

2514 Flora Norton-A very beautiful rich lavender entirely free from any mauve or pinkish tinge. The fowers are large and of fine form; one of the most delicate and pleasing shades ior norists use as a cut flower.

2515 Lady Grisel Hamilton-Beautiful silver lavender. 2516 Mrs. Walter wright-This new giant-flowering variety is a beautiful shade of mauve, clear and bright, with wings of a bright coerulean blue, shaded slightly with mauve.

PRICE-Any of above-named Sweet Peas, Plst., 5c.; 0z., 15c.; 1/4 1b. 40c.

\section{Orange and Salmon}

2522 Henry Eckford-The nearest approach to an orangeyellow in Sweet Peas; a beautiful color. Medium large and open form.

2523 Miss Wilmott-Enormous bold, upright flowers on stout stems. Wings and standard are of richest orangepink, delicately shaded rose.

\section{Striped and Variegated}

2505 America-Brightest blood-red striped white.

2506 Aurora-Orange-salmon, flaked and striped white.

\section{Our Sweet Pea Mixture}

Most pøople like as big a variety of Sweet Pea as they can get. To buy a dozen separate packets and six of them would be fare more "expensive than to buy an ounce of our Special Mixture, and even then the packets would not eontain nearly the assortment of colors found in this mixture. We make up these mixtures ourselves, using the best and most popular sorts in pleasing proportion as to colors and shades.

\section{Livingston's Special Mixture}

This superb mixture is our special pride. During the several years we have sold it, it has been our constant aim to improve and perfect it. The different kinds and sorts contained in this mixture are grown separately, so that we have an opportunity to choose only the largest and most beautiful varieties. These we mix ourselves in proper proportions for the most brilliant effect. It embraces the finest American and Eckford varieties, as well as the latest novelties, and will produce a great abundance of giant flowers of beautiful colors. Some are edged, mottled, blended, flaked and striped. Without exception, this is the very finest mixture it is possible to make. We recommend that our customers buy these seeds by weight and plant liberally.

2540 Special Mixture-Large Pkt., 10c.; oz., 25c.; 1/4 1b.,

\section{Livingston's Gilt Edge Mixture}

This is a very superior mixture, made up of over 50 of e finest named varieties; all bright colors.

2542 Gllt Edge Mixture-Pkt., 5c.; oz., 15c.; 1/4 lb., $35 \mathrm{c}$.

\section{Fine Mixed}

This mixture, for the price. will be found very satisfactory. It contains a great variety of choice colors and hades.

2543 Fine Mixed-Pkt., 5c.; oz., 15c.; $1 / 4$ lb., $25 \mathrm{c}$.

Sweet Pea "Nitroculture" adds to the size of the bloom and to the length of stem. In ordering be sure to mention Sweet Pea Nitroculture as there are other kinds. For full particulars, see Page 49.

\section{Sweet William \\ (DIANTHUS BARBATUS)}

very beautiful class of easily grown and very beautiful plants of extreme richness and diversity of colors. deliciously sweet-scented. For cut flowers they are not surpassed. Hardy biennial. Height 1 to $1 \frac{1 / 2}{2}$ feet.

\section{Holborn Glory}

This strain is a large-flowered selection of the Auricula-Eyed section, but most beautiful and admired of all sweet Williams. The individual flowers and trusses are of extraordinary size, and the range of color, all showof extraordinary size, and the range of color, all
ing a clear, white eye, is superb. 2640-Pkt., $10 \mathrm{c}$.

\section{Sutton's Scarlet}

The color of this variety is an intense scarlet similar to a Grenadin Carnation. 2649-Pkt., $15 \mathrm{c}$.

2643 Double Mixed-This mixture you will find of very superior quality; containing all colors and shades. Pkt., 5c.; $1 / 4$ oz., 20c.

2646 Single Mixed-A very choice assortment of all the best single-flowering varieties. Pkt., 5c.; $1 / 4 \mathrm{oz} ., 15 \mathrm{c}$.

2648 Double and Single Mixed-This mixture is made by blending the double and single-flowering varieties. Pkt., 5c.; $1 / 4$ oz.s, $15 \mathrm{c}$.; oz., $50 \mathrm{c}$.

Mrs. E. R. Lelman, Clark Co., Ohio, writes: "I have grown Asters for years, but have never found any to equal Heart-of France. One plant had 37 large flowers with stems 18 to 20 inches long. Your fine Mixed Coleus were were also the talk of the neighborhood."

Mrs. Mary M. Dickinson, Winnebago Co., Ill., wirtes: "I have just heard that you are said to have the finest Nasturtiums in the country and as I want to have the finest in our town, will you please send me seeds mixed to the value of the money enclosed."

Mrs. Wm. Rrueger, Rnox Co., Mo., writes: "I have always been more than pleased with seeds bought from you. The results. in health, pleasure and profit $I$ get from the cultivation of your famous Tomatoes and Nasturtiums alone repays me many times over for all labor put in my whole garden. 


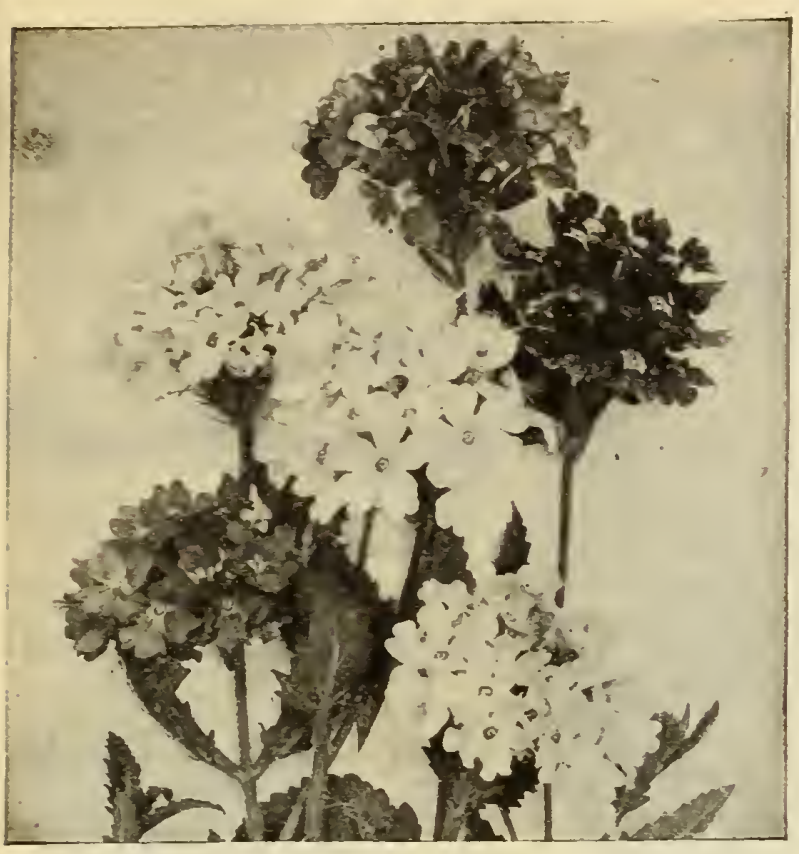

Iivingston's Irammoth Verbena. Pkt., $10 \mathrm{c}$.

\section{Livingston's Mammoth Verbenas}

If it were possible, it would seem to us that Verbenas are becoming more popular every year. The plants thrive in any good garden soil, and if grown from seed are much will flower perfectly from seeds. Height 1 to 116 feet.

2675 Helen Willmott-This new variety is a distinct color in Terbenas, being a bright salmon rose with a white eye. Pkt., $15 \mathrm{c}$.

2662 Mammoth Defiarce-Bright, rich scarlet; small leares. Pht., 10c.

2663 Mammoth Blue Varieties-Showy, distinctive; fine for edgings. Pkt., $10 \mathrm{c}$.

2665 Mammoth Pink Shades-Many very brilliant shades of pink. Pkt.. 10c.

2664 Mammoth Striped Varieties-Beautiful; a rich collection. Pkt., 10c.

2666 Mammoth Pure White-Iarge trusses of purest white flowers. Pkt., 10c.

2668 Mammoth Purple-Deep royal purple. Pkt., 10c.

Collection, one each of above 7 mammoth Verbenas, 50c. 2670 Iivingston's Mammoth Mixed Verbenas-Our strain of these elegant mammoth-flowering Verbenas will make beds and borders in the garden of the greatest brilliancy. These are our best Verbenas, and for enormous flowers of rich and superb best Verbenas, and for enormous flowers of rich and superb colors are unsur mixture contains every desirable color and profusely. Our mixture contains every desirable

2672 Fine Mixed-A very satisfactory assortment containing many fine colors and shades. Pkt., 5c.; $1 / 8$ Oz., 15c.; $1 / 4$ oz., $25 \mathrm{c}$.; oz., $90 \mathrm{c}$.

\section{Wallflower}

Well-known and deliciously fragrant half-hardy biennials the large spikes of bloom are of most beautiful colors. Height, $11 / 2$ feet

2690 Large-Flowering Single Mixed-Pkt., 5c.

2692 Large-Flowering Double Mixed-Pkt., $10 \mathrm{c}$.

\section{Chinese Woolflower}

2696-A new flower belonging to the Celosia family and one which promises to become popular. The plants average about 18 inches to two feet in height and shoot many laterals each of which form an oval-shaped flower-head. The flower is of a beautiful shade of crimson and resembles, somewhat, a ball of wool. It is a very free bloomer, continuing in flower until killed by heavy frost. Pkt., 15c.

PAGE 7 CONTAINS OUR FLOWER SEFD NOVEL TIES GIVE THEM A COICE PLACE IT YOUR GARTIES.

\section{Thunbergia}

Rapid-growing Annual Climber, with pretty buff, white and orange flowers of various shades, with a dark center 2654 Mired-Pkt., $5 \mathrm{c}$

\section{Valeriana (Hardy Garden Heliotrope)}

Showy plants; grow in any garden soil; do well in the shade. Hardy perennial; grows 2 feet high and blooms the first season from seed. Fine for bouquets. Bright rose, red and white varieties. 2658 Mixed-Pkt., $5 \mathrm{c}$

\section{Vinca (Periwinkle)}

Free-flowering, bushy plants, with glossy foliage and 政 all Summer; if potted before frost, will bloom in Winter: very easily' grown, blooming profusely the first season A very fine mixture of all colors. Half-hardy perennials. 11/2 feet high. 2680 Mixed-Pkt., 5c.

\section{Violet (Viola odorata)}

Stveet-scented, Fiolets are easily grown from seeds; and 列 the better. All varieties are of great beaut 2682 Sweet-scented-Old-fashioned Blue Violet. Pkt., $10 \mathrm{c}$ 2684 The Czar-Largest flowering deep blue. Pkt., 10c. 2686 Finest mixed-Blue and white sorts. Pkt., 10c.

\section{Wild Cucumber (Echinocystis)}

Rapid-groming annual climber. Has beautiful leaf and retts fragrant white flowers. 2695-Pkt., 5c.; 1/20z. 10c. pret $15 c$

\section{Xeranthemum (Everlasting Flowers)}

Very desirable. Easy to grow. Leares covered with silrery down. Hardy annual. Two feet. A very fine mixure of colors, 2697 Mired-Ptt.

Mr. C. J. Riebe, Trumball Co., Ohio, writes: "TWe have mars had cheaper seed nearer home, but found out last year that they are not as good. My Little Marvel Peas were several day's earlier than any peas in the neighborhood. I bought one ounce of your Special Sweet. Pea Mixture and tney were grand. I supplied the neighborhood with bouquets. Some days we picked 2,000 blossoms. Took first premium at the County Fair on Pompon Zinneas, and took first on vegetables and Prize-taker Onions."

Miss W. Brookman, Franklin Co., Ohio, writes: "I bought a packet of your New Aster, Heart of France, last Spring. Every seed grew.and I had the finest Asters anyer saw. You rere right when you said it was the best red Aster ever introduced."

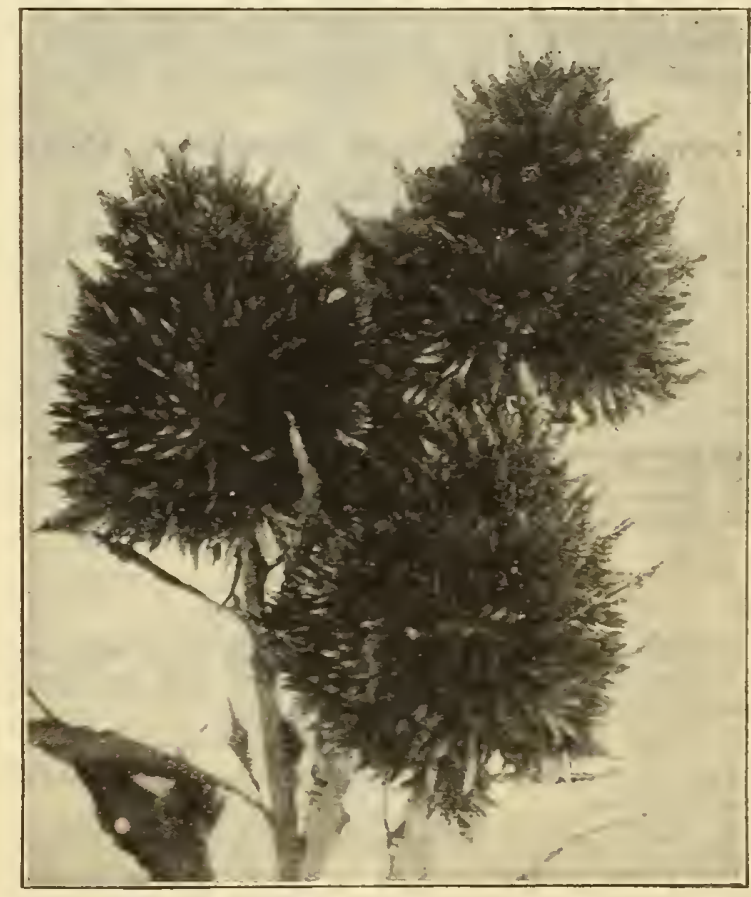

Chinese Woolfower 


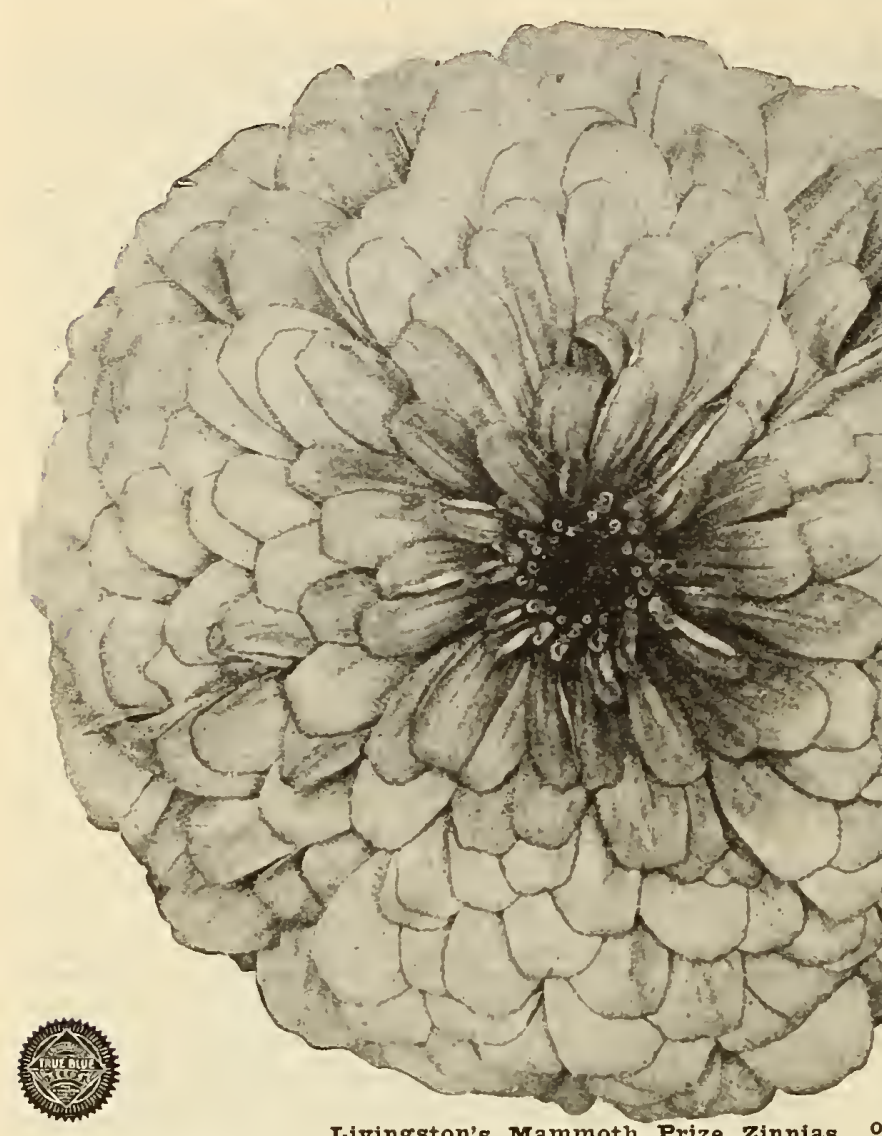

Livingston's Mammoth Prize Zinnias

\section{New Double Fringed}

A very fine new type. The petals of the perfectly formed double flowers are more or less deeply cut or fringed, giving them a more graceful appearance than the usual form. The plants are of compact habit, about 30 inches high, and have all the free-flowering merits of the family. We offer three separate colors.

2717 White, 2718 Deep Carmine, 2719 Bright Rose. Each, Plst., 10c.

Collection-A packet of each of the 3 Double Fringed Zinnias, $25 \mathrm{c}$.

\section{Striped, or Zebra}

A very pretty strain with striped flowers. Colors vary on each plant; presents a beautiful and curious appearance. 2721Plkt., 5c.

\section{Curled or Crested}

A fine strain, with large double flowers of perfect form; petals twisted, curled and crested into fantastic and graceful forms. 2723 -Pltt., 5c.; $1 / 4$ oz., $25 \mathrm{c}$.

\section{Tom Thumb, or Double Miniature}

Charming, perfectly double, smallflowering class; 10 inches high; bloom profusely. Fine for borders. 2725Mixed Colors-Pkt., $5 \mathrm{c}$.

\section{Double Pompom}

These Zinnas grow 2 feet high and are sturdy and bushy. They are also sometimes called "Lilliput" on account of their beautiful little flowers, which are very double and cone-shaped. 2727 All Colors Mired-Pkt., 5c.

\section{Improved Dwarf Zinnias}

\section{Livingston's Superior Zinnias}

One of our most stately and showy border plants; a strong grower and therefore succeeds well, even if the ground is not very rich. Excellent for cut flowers and continuously in bloom. Height 1 to 3 feet.

\section{Livingston's Mammoth Flowering Prize Zinnias}

These splendid large-flowering Zinnias (see illustration above) represent the very highest perfection in this flower, and for perfect doubleness, mammoth size, as well as the wonderful variety of colors and shades. are unsurpassed by any strain in cultivation. We offer the following splendid separate colors and our elegant mixture:

\begin{tabular}{l|l}
2700 Mammoth Crimson & 2704 Mammoth Pure White \\
2701 & Mammoth Dark Purple \\
2702 & Mammoth Flesh-Pink \\
2703 & Mammoth Lilac
\end{tabular} \mid $\begin{aligned} & \text { Mammoth Rose-Pink } \\
& 2706 \text { Mammoth Golden } \\
& 2707 \text { Mammoth Scarlet }\end{aligned}$

Above 8 sorts, each 5c. per packet; $1 / 4$ oz., 20c.; oz., finc.

2710 Livingston's Mammoth Flowering Prize Mixture - A gorgeous mixture containing many new and rich hues. Pkt., 5c.; 1/4 oz., 15c.; oz., 50c.

Page 7 contains our flower seed novelties. Don't overlook them.

Our flower seed collections on inside back cover are rare bargains and should have a place in every garden.
This strain, not growing so high as Livingston's Prize Zinnias, is especially desirable for borders, edgings and small beds. The individual flowers are nearly as large. 2714 Improved Dwarf Mirture-Pkt., 5c.; 1/4 oz., 20c.; oz., $60 \mathrm{c}$.

Mrs. C. Koch, Jackson Co., Mo., writes: "Everything
grew fine, and our Sweet Peas surpassed any that I had
ever seen and were greatly admired."

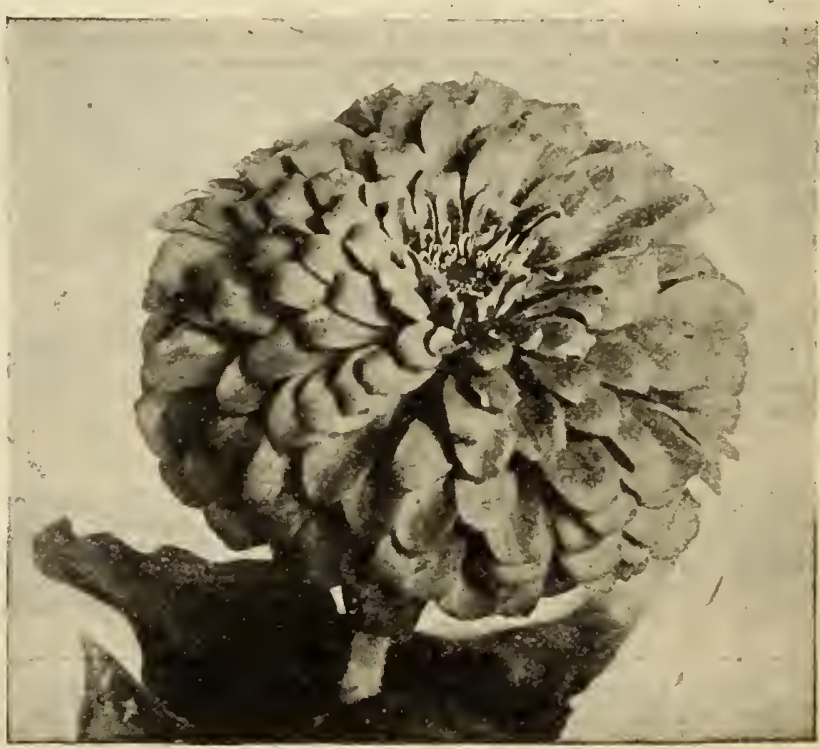

Improven Draif Zinr.ias 


\section{Prices sabjeet Lawn, Orchard and Garden Tools}

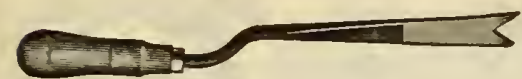

Asparagus Knife-No tool equals it for removing dandelions, plantain, dock, etc., from lawns. Drop forged cutlery steel, $45 \mathrm{c}$, postpaid.

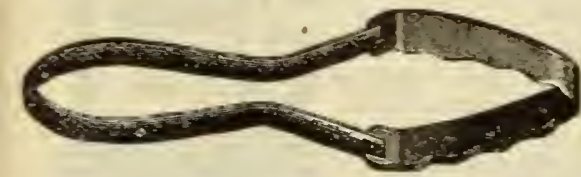

The New Christy Garden weeder has the famous scalloped cutting edge of the Christy Bread Knife. 25c., postpaid.
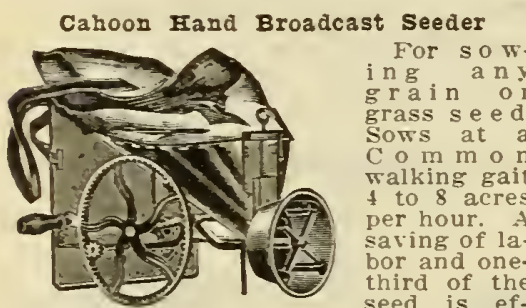

fected by this machine. Reed is ef respects, Price, \$5.00; weight 9 lbs. Not prepaid.

Iittle Giant Seeder

Strongest, Iightest and Easiest Running

Best and cheapest crank Seeder made in the quality of work done and durability. "Will not get out of order nor be affected by dampness of the

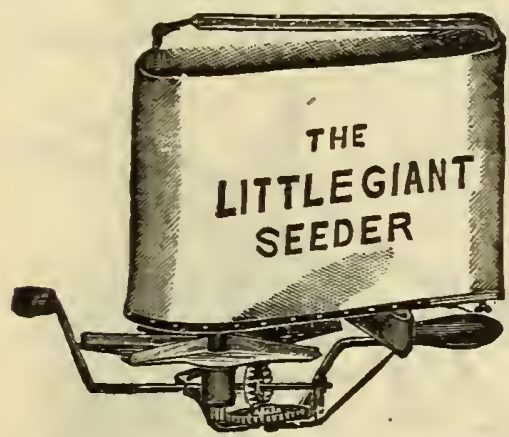

weather. Distributes all kinds of fer tilizer, land plaster, ashes and seeds. We have sold it for years with good satisfaction. No. $3, \$ 2.00$. Weight 6 lbs. Not nrepaid.

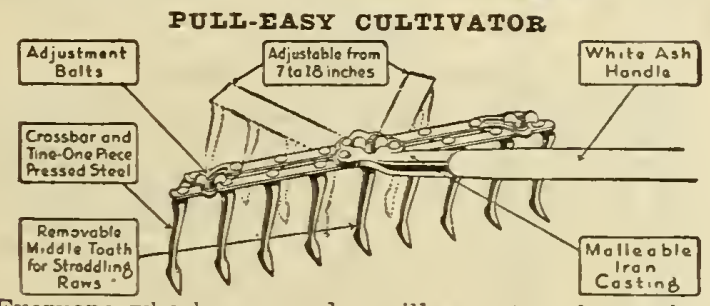

Everyone who has a garden will see at a glance the ad vantages of the "Pull-Easy" over any other kind of garden tool. The shape of the teeth stir it up and pulverize it thoroughly without the operator being obliged to exert any downward pressure on the handle. Can also be used as a rake in preparing the soil, as illustrated, $\$ 1.40 ; 4$ tooth. adjustable 2 to $T$ inches, foc., not prepaid.
Excelsior WeederVery usetul for wheed ing seed beds, stirring soil in hot-beds, cold post paid.

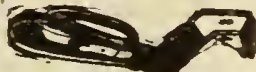

Iang's WeederDoz., \$2.25; each, 25 c., postpaid.

Hazeltine Hand Weeder In steel, tempered, $3 / 8$ inch wide and $1 / 8$ inch thach 35 c., postpaid.

Perfect Clinching Hose Mender

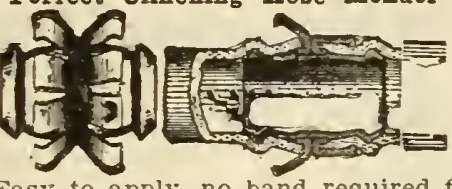

Easy to apply, no band required for 4 or $1 / 2$-in hose. We use the Clincher Simply pound down the Clincher and rou have a neat and permanent mend.

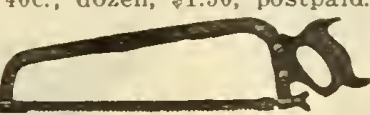

Swivel Blade Pruning Saw.

The blade can be set at any angle. Atkins best grade saws-16-in. blades No. 11, with triangular frame, $\$ 1.65$ post paid.

Praning Saw-Double Edge

One coarse and one fine, 18-inch

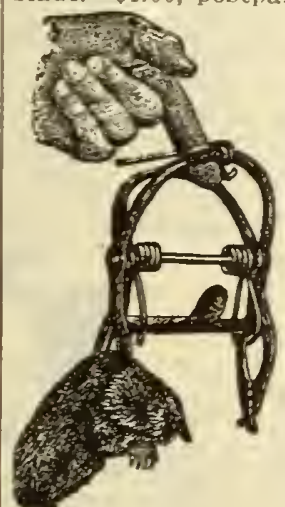

"Out of Sight" Claimed to be the best NI o le Trap ever ofhas to be tried to be appreciated. Can be used in hot-beds unsecret of catching moles in a good trap and a their habits. Full directions a $\mathrm{r}$ e der sash. The sent with each trap. \$1.25. post-

Van Eeyper's Glazing Points

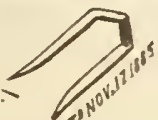
Prevents glass from sliding. Made of galvansingle-strength glass; No.
$21 / 2$ for double-strength. Box of 1000,65 c., postpaid.

\section{Garden Dibber-For plant-} ing bulbs, etc. Has hardened steel point. $60 \mathrm{c}$, postpaid.

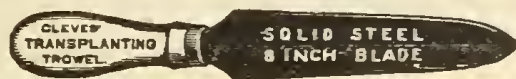

Steel Transplanting Trowel-Firstclass for digging $\pi$ eeds and resetting
plants. 5-in., 25 c., 7 -in., $35 \mathrm{c}$, postpaid.

\section{Garden Trowels}

Ordinary, 5-in., 15c.; 6-in., 20c., nostpaid.

Pressed Steel, 6-in., 40c., postpaid. Forged Steel, 5-in., 60 c.: 6 -in., 65
-in., $70 \mathrm{c} .$, postpaid.

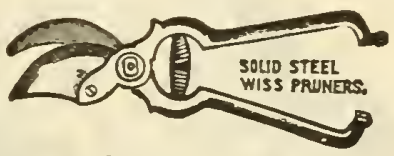

Guaranteed, 9-inch, $\$ 3.25 ; 10$-inch, $\$ 3.50$, postpaid.

Pexto, high grade, medium price shear (guaranteed). $\$ 1.75$, postpaid.

Common-Very strong. Best steel blade and excellent spring. $\$ 1.00$, postpaid.

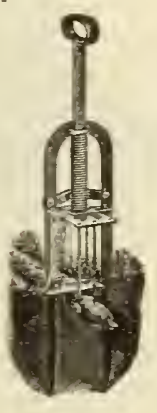

RITTENHOUSE S S I F-
SETTING MOIE TRAP
Simple, sure and safe,
The spears are made of
spring steel, balance of
trap is of steel and heav-
ily tinned, making it very
attractive and durable.
Directions for set t ing
come with the trap. $\$ 1.25$, postpaid.

\section{HEDGE SHEARS}

Best steel and just the thing for trimming Privet Hedge. 6-in., \$1.25, ( $\mathrm{W}^{\mathrm{t}}$ 5 lbs.) ; 9 -in., $\$ 2.00$

Clipper Grain and Seed Cleaner

No. 1, for general use, has 12 sieve $(10$ zinc), cleans grain and seeds of all kinds. Each $\$ 30.50$, not prepaid. Sends.

\section{MCWHORTER FERTILIZER DISTRIBUTOE}

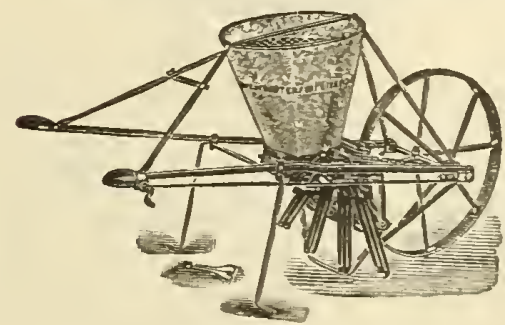

For distributing all commercial fertilizer. It distributes the fertilizer in growing crop, as a growing crop, as a broadcaster to any extent up to a uni$t$ wo feet, and in any quantity from a fei pounds to 40 or more pounds to the Especially adapted to applying fertilizer to strawberries or other similar planted crops. $\$ 17.00$. not prepaid. 


\section{Lawn, Orchard and Garden Tools Prices Subject to Change}

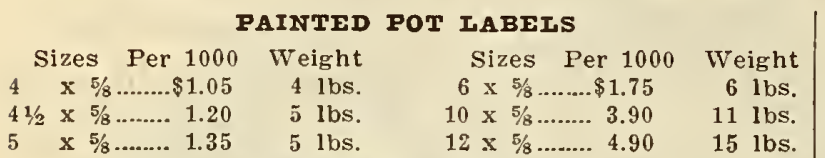

GARDEN STAKES

Sizes

$8 \times 7 / 8$

$10 \times 7 / 8$

$12 \times 1 \frac{1}{8}$

Per 1000

$\$ 4.90$

6.40

Per $100,90 \mathrm{c}$, not prepaid

\section{CANE STAKES}

Good, strong, natural canes. From Southern cane brakes, running 6 feet in length. $\$ 1.75$ per $100, \$ 3.75$ per bundle of $250: \$ 14.00$ per 1,000 , not prepaid.

\section{WATERS PATTERN TREE PRUNER}

"Keen Kutter" make. Will cut green limbes up to one inch in diameter cutting head, handle and handle shank securely attached so will not work loose. Best steel blade and spring. $8 \mathrm{ft}$., $\$ 1.50 ; 10 \mathrm{ft} ., \$ 1.75 ; 12$ ft., $\$ 2.00$. not prepaid.

\section{HOT-BED SASH}

Best Cypress-31/3x6 ft., unglazed for 4 rows $8 \times 10$ glass. Each, $\$ 2.25$; 10 for $\$ 22.00$. Not prepaid.

Our sales on hot-bed sashes are increasing each season, so satisfac. tory do our customers find them.

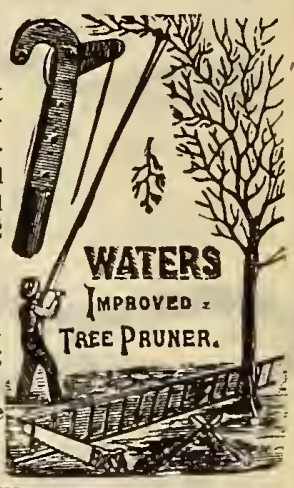

\section{prices subject to change Planet Jr. Farm and Garden Tools prices, not prepaid}

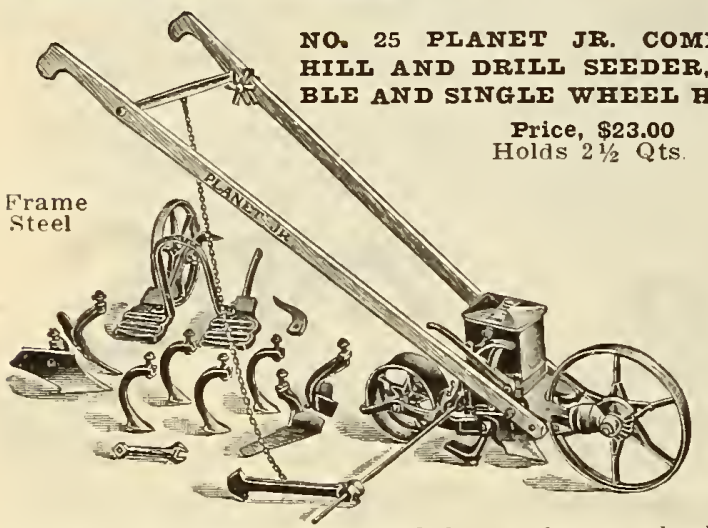

\section{No. 17 PIANET JR. SINGIE WHEEI HOE}

The highest type of single wheel Hoe made. Light, but strong, and can be used by man, woman or boy. Hoes, plows and cultivates all through the season. A hand machine that will pay for itself in time anci labor saved in a gle season.

\section{PIANET JR. STAR PULVERIZER, IEVEIER AND}

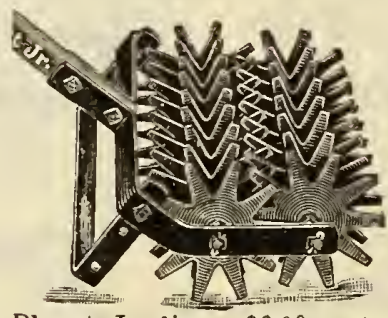

Greatest tool ever devised for preparing the seed bed. It smoothes and refines the soil, putting it in the best possible condition for seeding. than the ordinary garden rake. Works equally well $131 /$ inches. As a cultivator it is great for destroying weeds, breaking the crust and leaving a fine mulch. More than one customer has reported "would not do without it for any price." One of the

Planet Jr. line. $\$ 6.00$, not prepaid.

No. 8 PLANET JY, HORSE HOE AND CUITIVATOR large enough acreage in crops for a double wheel hoe to seeders and wheel hoes separately; and for the family garden where a double wheel hoe is preferred.

Wo. 4 PLANET JR. COMBINID HIII AND DRIII SEEDER, WHEET HOE, CUITIVATOR AND PLOW Price, Complete, .\$19.50

Sows all garden seeds (in hills or drills), plows, opens furrows and covers them, hoes and cultivates all through the season. A hand machine that does the work so easily, quickly and thoroughly that it pays for itself in a single

No. 4D, Hill and Drill seeder, same as above less the ultivating attachment, $\$ 15.50$.

No. 11 PIANIT JR. COMBINED DOUBIE AND SINGIE WHEEI FOE, CUITIVATOR, PIOW AND RAKE

Price, $\$ 16.00$ Straddes crops till 20 inches high. then works between. Has steel wheels. The greatest hand cultivating tool in the world.

No. I2 PIANET JR. DOUBIE AND SINGIE WHEEL HOE Price, $\$ 12.50$

This tool is identical with No. 11 Double Wheel Hoe, except the equipment; has hoes that are wonderful weed killers. The Plows open furrows, cover them and hill growing crops. The Cultivator Teet

\section{RED CROSS RAT AND MOUSE}

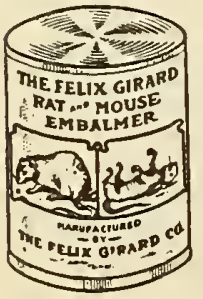

Clears them out in one night. No odor -it dries them up. Has peculiar properties attractive to rats and when used acinfested premises in one night. It con. tains no phosphorus, which is condemned by government experts on account of fire danger. Successfully used by the largest flour mills, warehouses and industrial establishments in the country. Order Red Cross Rat Embalmer to rid your premises of rats and mice. We do not as we have used it to rid our own buildings of rats and mice which it done most satisfactorily. $1 \mathrm{lb}$. (enough for $1500 \mathrm{sq}$. ft. floor space), $\$ 3.00 ; \mathrm{t} / 4 \mathrm{lb}$.

Stronger, better made and finished than any other one-horse cultivator, and enables you to increase your yield because it does a greater variety of work in corn, cotton, potatoes, toqucco, and other crops requiring similar cultivatio oughly.

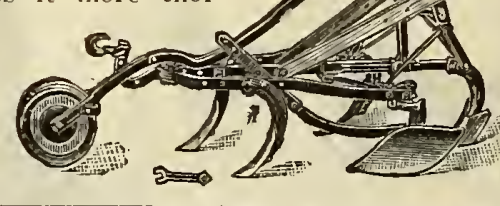

72-Page Planet Jr. Catalog Free

Describes 55 tools, including Seeders, Wheel Hoes, Horse Hoes, Harrows, Orchard and Beet Cultivators. Write postal for it.

\section{CARBOLA}

Germ-Killing White Paint

Carbola is a white paint in powder form combined with a disinfectant many times stronger than pure carbolic acid. It is non-poisonous and non-caustic. It kills lice, mites, fly eggs, etc, and helps prevent the start and spread of contagious diseases that affect man, beast and fowl. Carbola is two things in one-a paint that disinfects or a disinfectant that paints. It dries a clear snow white. It saves labor, time and money. It paints and disinfects at one operation in the same time.

Carbola is recommended for use instead of whitewash in every place where whitewash ordinarily is used.

One pound makes a gallon of paint which will cover about 200 square feet. depending upon the character of the surface painted. Trial pkg., 25c.; 10 pounds ( 10 gallons), $\$ 1.00 ; 20$ pounds ( 20 gallons), $\$ 2.00 ; 50$ pounds (50 gallons), $\$ 4.00$ : barrels (about 300 pounds), per pound, $7 \mathrm{c}$., not prepaid. 
Prices sabject $\quad$ Reliable Well Built Sprayers

SPECIAI TIN SPRAYER

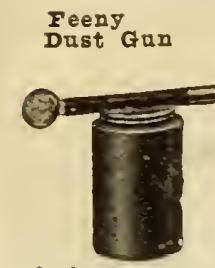

of that even remotel not now any dusting derice we know gun. Made of the best material; no complicated niechanism, works equally well on trees, shrubbery or vegetables, applying powdered arsenate lead, paris green, etc., $\$ 2.50$, not prepaid. Weight, 3 lbs.

A successful h a $\mathrm{n}$ d sprayer for poisons and lisinfec $t$ a $n t s$ in powder form. Ball valve arrangement al-
lows no dust to

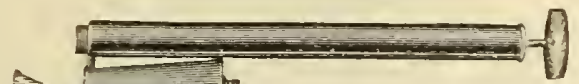

Powder Sprayer reach the plunger head-2-inch can screw for filling-holds 1 qt.-22 inches long-aluminum finish, $95 \mathrm{c}$. postpaid.

\section{No. 120-"EASY" COMPRESSED AIE SPRAYER}

Has a large powerful pump.

automatic shut-off nozzle. Suit- rer disinfecting and rery

desirable for spraying large

more in 10 minutes with this than an hour With any quart sprayer. 23 inches long-
holds 1 gallon. Galvanized. $\$ 260$, postpaid.

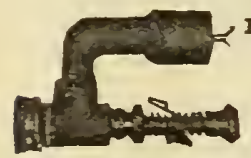
IMPROVED VERMOREL NOZZIE-NO. 136

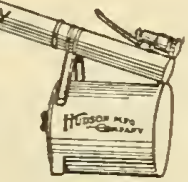

tood general purpose nozzle and best for ghitew shing Pushing the plunger cleans any obstruction out of nished with 5 caps for coarse or fine work. $80 \mathrm{c}$. postpaid. "HARDIE" BUCEFT PUMP-NO. 10

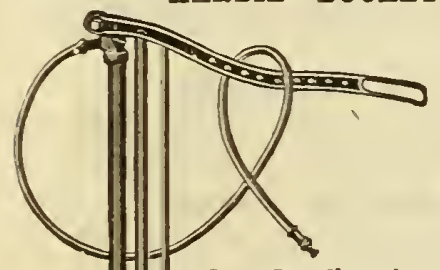

This is the only bucket pump in the market that is giving entire satisfacthe large barrel pumps. is capable of developing a 200-1b. pressure and maintaining a $100-1 b$ pressure while spraving. with 35 strokes to the minute, and will discharge 30 gallons of liquid per hour.

One 5-gallon heavy wooden bucket, 3 feet best 10 -inch hose, 1 sprating lance, 18 inches long 1 sprayino nozzle $\$ 1200$ : 8-ft extension rod, $75 \mathrm{c}$., not prepaid.

\section{THE "PERFECTION" SPRAYER No. 110}

Built Iike a Steam Boiler
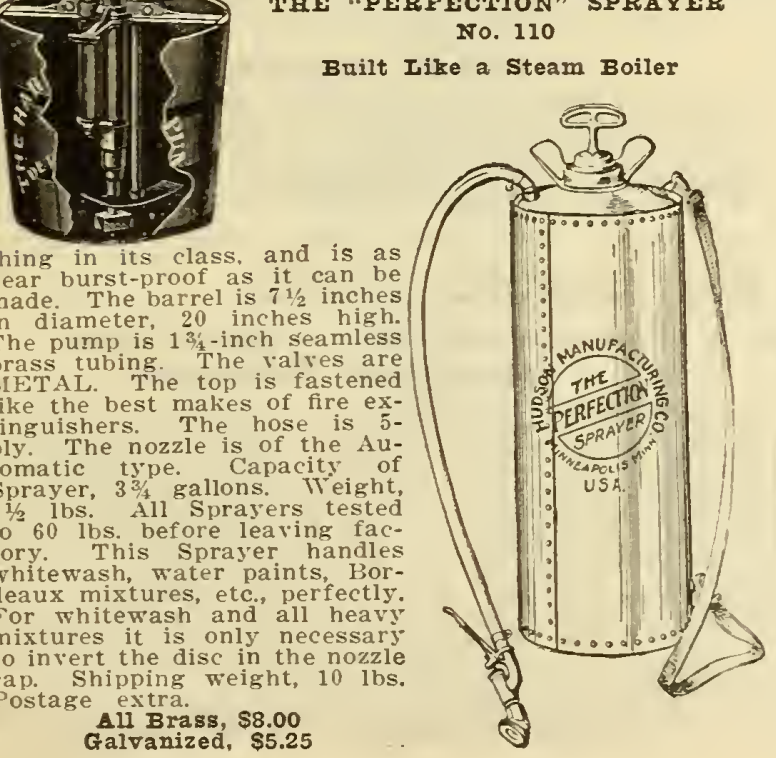

A special type de-

signed for use in gar-

dens, houses, stables,
and fields, It does
good work and has

every feature of

No $112-19$ ins long holds 1 quart. $55 c$ postpaid.

No. $122-14$ ins. long, holds $1 / 2$ pt. $45 \mathrm{c}$, postpaid.

HEAVY GIASS JAR SPRAYER-NO. 101B

II orks easier,

stays in order bet-

ter and lasts long-

er of its class.

With quart Mason jar; Brass Tubes; zine

jar top; non-adjustable plunger rod." $85 \mathrm{c}$., postpaid.
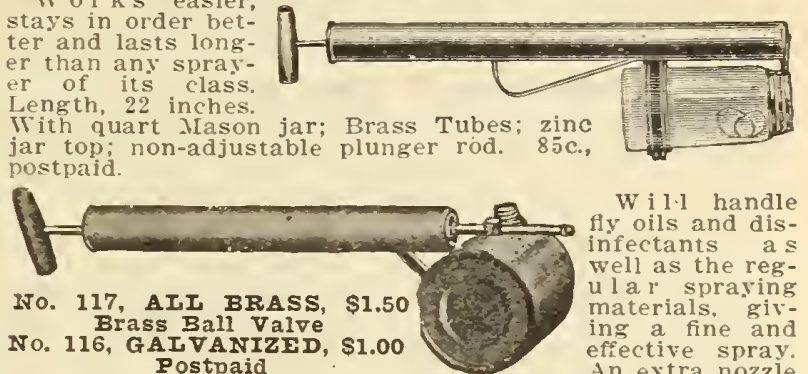

W i l.l handle

y oils and dis effective spray.

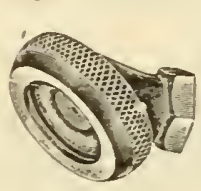

NON-CIOG NOZZLE
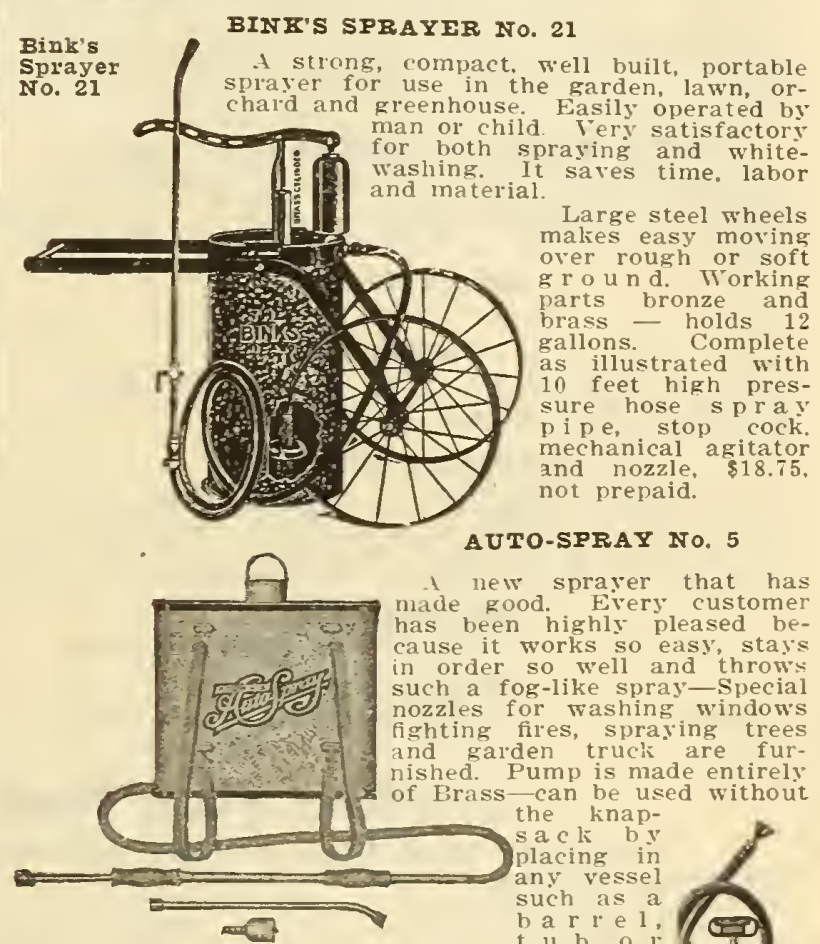

bucket. Pump hose nozzles and strainer Galvanized Knapsack Tank, \$3.5\%; curved extension rod for field spraying; $60 \mathrm{c}$., not prepaid. MEYERS IITTIE GIANT BUCEET PUMP This pump has a place between the hand atomizer and barrel pump. Being made of brass with brass ball valves, will not rust or corlode. Has malleable iron foot rest. jet agitator, im. proved brass air chamber and two nozzles for coarse and fine spraying. This is a genuine
Meyers product and in a different class than the many" so-called "bargain" bucket puinns. $\$ 4.25$, and worth it: $8-$ foot extension rod, $75 \mathrm{c}$. not prepaid. Weight $T$ pounds.

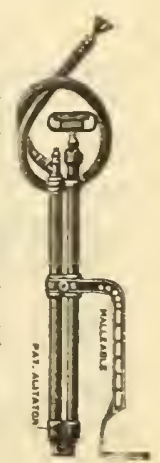


All prices on this page are subject to change. Items marked (*) CANNOT be mailed.

We have found the preparations listed on this page the very best. Directions for use are on each package.

To protect your trees, flowers. shrubbery and vegetables from insects and blight, it is necessary to spray them-ask for our free spraying calender if in doubt when to do it and what to use.

\section{Reliable Spraying Solutions}

\section{*APHINE}

For destroying aphis (plant lice) on roses, sweet peas, nasturtiums, etc. A fine article $1 / 4 \mathrm{pt}, 25 \mathrm{c} ; 1 / 2 \mathrm{pt} ., 40 \mathrm{c}$.

\section{*ARSENATE OF IEAD (PASTE)}

Used largely with Bordeaux Mixture for spraying pota toes and fruit trees. Sticks longer and no danger of burn ing the foliage as with paris green. Lb., $45 \mathrm{c}$.. not prepaid

\section{*ARSENATE OF IEAD (Powdered)}

Mixes with water almost instantly-one pound goes as far as two to three of paste-remains in suspension much longer. We have given a five-year test to the brand we

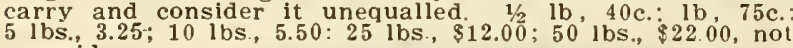
prepaid.

Highly recommended by the Experiment Stations as a spray for Black Aphis and sucking insects of this class You cannot go wrong in ordering "Black Leaf 40 " for vegetation. As a dip to destroy scab, ticks, lice and insect pests on sheep, cattle and hogs dilute 1 pound in 83 gal
lons of water. 1 oz. $25 \mathrm{c} . ; 1 / 2$ lb., $\$ 1.00: 2$ lbs., $\$ 3.2510$ lbs $\$ 13.75$, not prepaid.

\section{*BORDO IEAD (Key Brand)}

Kllls leaf-chewing insects, and at the same time protects the crop against fungus disease such as apple scab and potato blight. We advise our customers to use Bordo Lead on their fruit trees. potato and tomato vines, cu cumbers, melons, etc. It sticks and protects the foliage All ready to use by adding cold water. Bordo-Lead will not only increase the crop. but will improve the quality. This combined spray saves mixing and if used before bugs or blight appear. it gives best results possible. 1 pound makes 5 gallons spraying solution. 1 lb., $45 \mathrm{c}: 5 \mathrm{lbs}$,
$\$ 2.00: 10$ lbs.. $\$ 3.50: 25 \mathrm{lbs} . . \$ 6.50$. not prepald.

*QUICK BORDEAUX MIXTURE (Key Brand)

A superior article ready for immediate use for blight on flowers, vegetables and trees. Used largely with Arsenate of Lead for spraying potatoes and trees, 1 pound makes
5 gallons. $1 \mathrm{lb}, 30 \mathrm{c} ; 5 \mathrm{lbs}, \$ 1.00: 10 \mathrm{lbs} \$ 1.75$ not prepaid.

\section{GRAFTING WAX}

$1 / 4$ lb., 15c.; $1 / 2$ lb., 25c: 1 lb., $45 \mathrm{c}$, not prepaid.

\section{*HEIIEBORI}

For the destruction of slugs, worms, caterpillers. etc Safe to use when the vegetables or fruit are about ripe. $1 / 2$ lb., $40 \mathrm{c}$.: 1 lb. $75 \mathrm{c}$., not prepaid.

\section{FAMMOND'S SIUG SHOT}

Non-poisonous; no danger to the person using it. It is the best insect destroyer ever offered for potato bugs. it every year. It is simply dusted lightly on $1 \mathrm{lb} .15 \mathrm{c}$. 5 lbs., 45 c.; 10 lbs., $80 \mathrm{c}$; 25 lbs., $\$ 1.85$; not prepaid.

\section{TOBACCO DUST}

$10 \mathrm{lbs} ., 65 \mathrm{c} . ; 50 \mathrm{lbs} ., \$ 3.00 ; 100 \mathrm{lbs} ., \$ 5.75$, not prepaid.

TOBACCO STEMS

50 lbs., $90 \mathrm{c}$; 100 lbs., $\$ 1.65 ; 500 \mathrm{lbs}$., $\$ 7.50$, not prepaid.

\section{IIME AND SUIPEUR POWDERED}

Mixes with water-becomes a liquid testing the same as standard liquid solutions. It is claimed that the brand we carry is the only powdered form that is exactly the same as standard liquid solutions and can with safety to the tree be used in combination with an arsenate as a summer spray without the disadvantage of bulk. weight. leakage, etc. $1 \mathrm{lb}, 40 \mathrm{c}$; $5 \mathrm{lbs} ., \$ 1.50,10 \mathrm{lbs}$., $\$ 2.50 .25 \mathrm{lbs}$., $\$ 4.35 ; 50$ lbs., $\$ 8.50 ; 100$ los., $\$ 15.00,200$ lbs., $\$ 27.00$ not prepaid.

*"NICO-FUME" IIQUID (40\% "Free Nicotine")

The best spray for greenhouses. The fumes help to kill the insects. One or two teaspoonfuls to the gallon of fresh water "Nico-Fume" Liquid has the advantage of belng employed both for spraying and fumigating $1 / 4-1 \mathrm{~b}$. tin $65 \mathrm{c}$ : $1 \mathrm{lb}$., $\$ 2.00 ; 4 \mathrm{lbs}, \$ 7.50 ; 8 \mathrm{lbs}, \$ 14.50$, not prepaid.

\section{"NICO-FUME'" TOBACCO PAPER}

To use, "hang sheet from hole punched ir. one end, blow out flame and let sheet burn." Eight or ten sheets for the ordinary greenhouse ( $100 \mathrm{ft}$. long by 20 feet wide) will usually furnish a strong fumigation against green fly, etc 24 -sheet can, $\$ 1.25144$ sheets, $\$ 5.00 ; 288$ sheets, $\$ 9.50$; all postpaid.

$1 / 4$ lb, 20c.: 1/2 lb. 35c.; lb, 65c; 2 lbs., $\$ 1.25$, not prepaid

\section{PYROX (BOwkers)}

A pasty substance, used for leaf-eating insects and blight. It is really a Bordeaux and Arsenate of Lead com. bined and is excellent. Dilute $1 \mathrm{lb}$ to 5 gallons water It is a superior article that is giving results. $1 \mathrm{lb}, 40 \mathrm{c}$; ; \$1 15 , 1 bs.. $\$ 3.00 ; 25$ lbs., $\$ 6.25 ; 50$ lbs., $\$ 11.00$ : 100 lbs. $\$ 20.00300$ lbs. $\$ 57.00$, not prepaid.

\section{*SCAIECIDE}

Used for the destruction of San Jose Scale Dilute 1 gallon Scalecide in 15 gallons water. Use in the Fal after the leaves are off of trees and early in the Spring be-
for the buds start. Qt., 65c. 10 gals $\$ 11.70^{\circ} 30$ gals., $\$ 28.85 ;^{50}$ gals., $\$ 43.00$, not prepaid

\section{SOAP (FISA OR WHATE OII}

An excellent wash for trees and plants. Used with Black Leaf 40 in combatting hard-to-conquer sucking insects $1 / 4$ lb., $15 \mathrm{c} .: 1$ lb., $35 \mathrm{c}$.; 2 lbs.. $60 \mathrm{c}$., postpaid.

\section{SOAP ("RED SNAPPER" PLANT)}

A combined nicotine, flsh oil, sulphur soap. A very effective plant cleanser and insect killer. $1 / 2 \mathrm{pt}$. can, $25 \mathrm{c}$. not prepaid.

*WEED KILIER (TARGET BRAND)

Keeps paths and roads free from weeds and grass. One gallon makes 50 gallons ready for use-enough for 150 yards of surface; applied wlth watering can. By express or freight: 1 pt., $40 \mathrm{c}$; 1 qt., 70c.; 1 gal., $\$ 1.75$, not prepald.

\section{SPECIAL SUGGESTION}

Combine Black Leaf 40 with either Bordo-Lead or Pyroz and you have a complete spray for sucking insects, chewing insects and many blights. Be prepared. It will pay you to have these necessary articles always on handBlack Leaf 40 and either Bordo-Lead or Pyror. Used by all successful gardeners. farmers and orchardists.

\section{Fertilizer, Plant Food, Etc. Analygis of any of the Fertil-}

Special Prices by the Ton or Car Load. All Prices F. O. B. Columbus, and Subject to Market Changes.

Armour's Bone Mea1-10 lbs, 50c; 25 lbs, $\$ 100 ; 50$ lbs.

$\$ 1.85$; 1 bag ( 125 lbs.) $\$ 3.75$.

Armour's 2-10-4-10 lbs., 50c.; 25 lbs., \$1.10; 50 lbs.

$\$ 2.90$; 1 bag (125 lbs.) $\$ 4.00$.

Armour's 2-12-2-10 lbs., 50c.; 25 lbs., \$1.00; 50 lbs.,

$\$ 1.85 ; 1 \mathrm{bag}(125$ lbs.) $\$ 3.75$.

Armour's 16\% Acid Phosphate-10 lbs., 35c.; 25 lbs. c.; 50 lbs., $\$ 1.35: 1$ bag ( 125 lbs.) $\$ 2.60$

Cattle Manure (shredded) -10 ibs., 50 c.: 25 lbs., $\$ 1.00$; 50 lbs., $\$ 1.50 ; 1$ bag (100 lbs.), $\$ 2.50 ; 1000$ ibs., $\$ 20.00$; ton, $\$ 38.00$

Sheep Manure (palverized) -10 lbs., 50c.; 25 lbs., \$1.00; 50 lbs., $\$ 1.60 ; 1$ bag (100 lbs.) $\$ 2.75 ; 1000$ ibs., $\$ 22.00$; ton. Nitrate of Sodar-1 lb., 20c.; 2 lbs., 35 c.; 5 lbs., 65c.; 10 lbs., $\$ 1.00 ; 25$ lbs., $\$ 1.90$ : 50 lbs., $\$ 3.35 ; 100$ lbs., $\$ 6.15 ; 200-$

\section{"RED SNAPPER" PIANT FOOD}

Especially prepared for house plants, ferns, palms. etc. Supplies just what the plant needs and vill promote the growth of rich colored healthy foliage and an abundance of well marked beautiful flowers. Fed to outdoor plants it is just as valuable When we explain that it is made of fish, tobacco and bone flour, the right quantity of each properly compounded, you can understand. why its great value as a plant food. It is so made as to be clean and vanitary for use in the finest homes Full directions sanitary for use in the finest homes pull directions Snapper" Plant Food we furnish free an 8-ounce package of Plant Tonic. Trial size, 25c; 24 ozs. $50 c^{4} 4$ lbs, $\$ 1.00$. not prepaid. A valuable booklet, "Care of Piants." ls en: closed in each package of Plant Food

To build up the fertility of your soil, use the inoculator as directed on page 49 for the best results. 


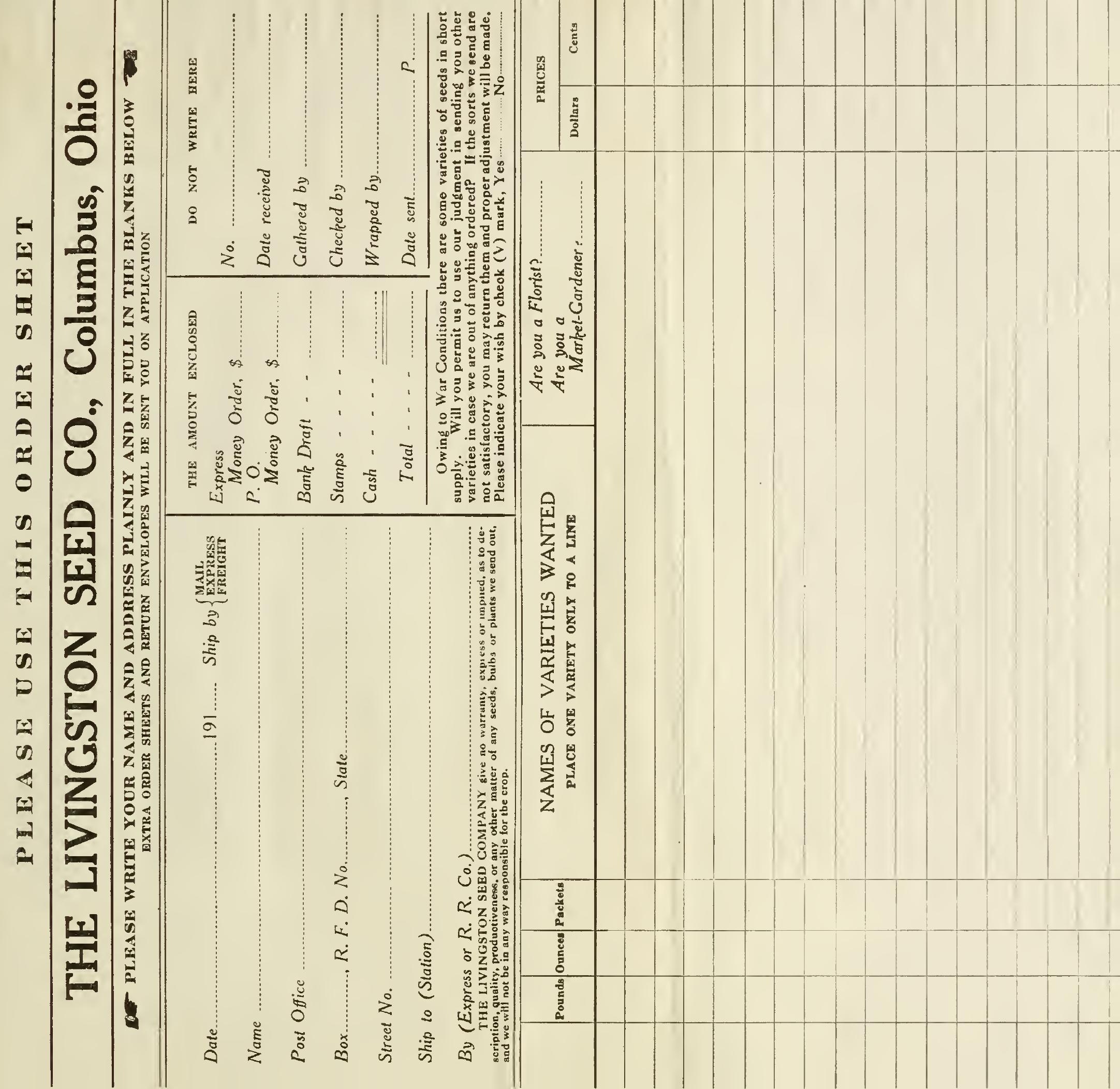




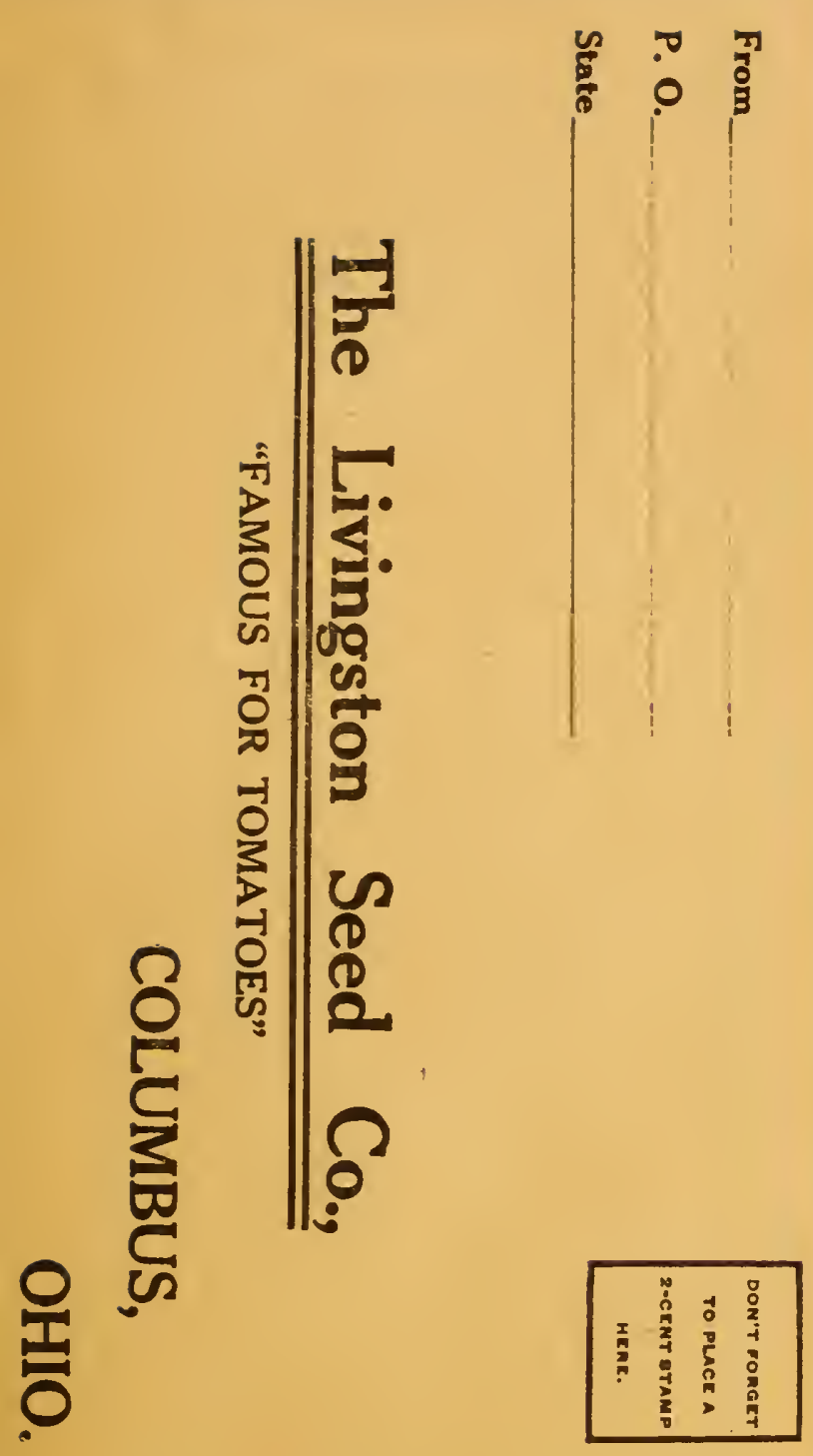




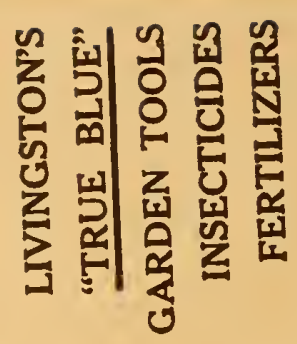

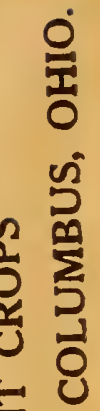

น

5

12

o

[a)

$\ln 5$

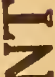

$\infty$

a

$02 \geq$

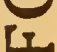

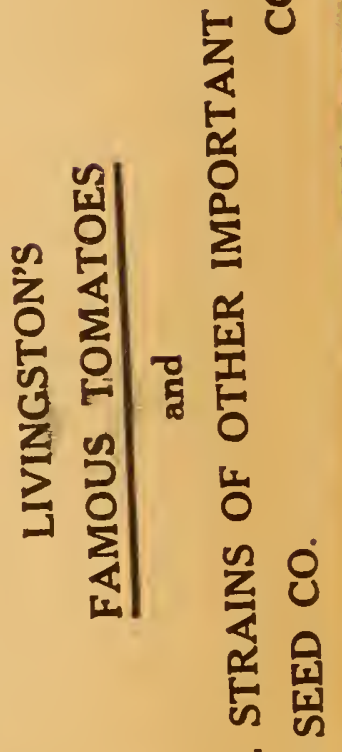

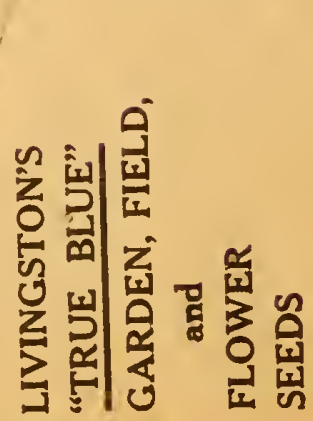

近

ค 0

$\sum$

닙 


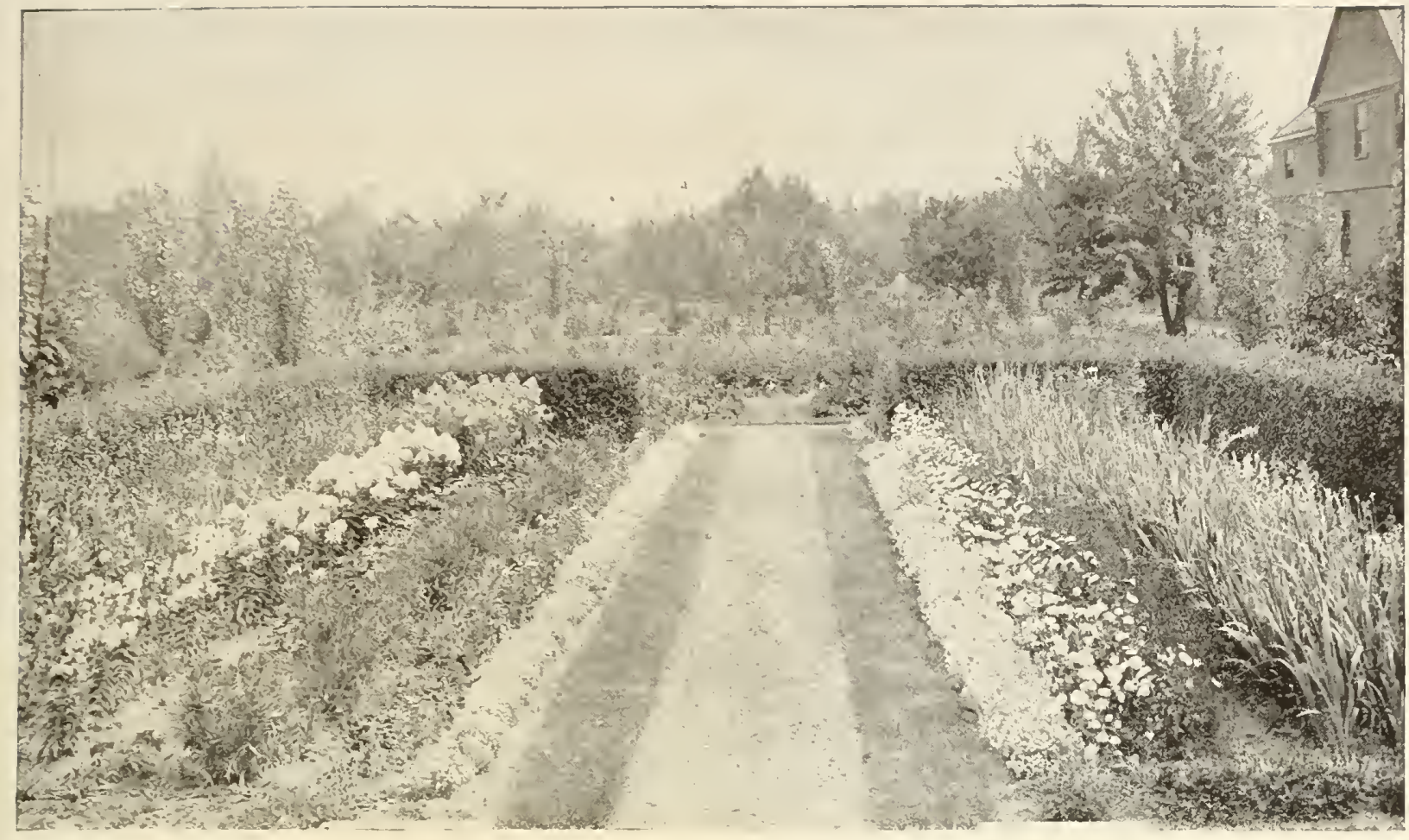

\section{Our Bargain Collections of Flower Seed}

$50 \mathrm{c}$

IIVINGSTON'S RAINBOW COLLECTION OF CHOICE ANNUAL FLOWERS

Asters Mixed

Bachelor's Buttons Mired

Candytuft IMixed

Cosmos Mixed.

Dianthus Mixed

Marigold Mixed

Mignonette Sweet

Nasturtium, Inized

Pansy, Misea

Petunia Mixed

Phlox Mixed

Poppies Mixed

Portulaca Mixed

Scabiosa Mixed

Alyssum Sweet

Antirrhinum Mixed

Sweet Peas, Mixed

Zinnia, Mised

If purchased separately this collection would cost $\$ 1.00$.

\section{$25 c$}

GREAT COLLECTION OF SUPERB SPENCER SWEET PEAS

\section{Astha Ohn \\ Captain of Blues \\ othello}

White

King Edward

Countess

$50 c$
$25 c$
$\$ 1.00$.

\section{$25 c$}

Sweet Alyssum

Candytuft Mixea

Nasturtium Mixed

If purchased separately this collection would cost $50 \mathrm{c}$.
$50 \mathrm{c}$

Semples Mixed

Ostrich Plume Mixed

Comet Mixed

Sensation

\section{0c LIVINGSTON'S COIIECTION PEREN-}

Aquilegia, Coerulea

Campanula Prize Mixed

Coreopsis Lanceolata

Shasta Daisy

If purchase

If purchased separately this collection would cost $70 \mathrm{c}$

\section{Wild Flower Garden, or Children's Garden}

Especially adapted for producing a display in large borders, or sowing along woodland walks, railroad embankments, for hiding an unsightly fence, stump, etc. Nothing in the way of flowers delights children more than this wIID GARDEN, chiefly because they can be allowed to pick their own bouquets without stint. Sow in drills 2 feet apart. or even broadcast. Cover lightly and keep the soil from drying out until started. 2740 Our Extra Choice Mixture-Large Fkt., 10c.; 1/2 oz., 15c.: oz., 25c. Ask for Special Price by the Pound,

\section{Have You a Hardy Garden?}

So much interest is being displaved in the hardy perennial flowers at the present time that a few words here regarding them may not be amiss. You will find throughout our List Seeds of many of the most popular sorts. Perennials are not difficult to grow, but most of the varieties are slower in starting than the annuals, so that care shoul be taken that the ground does not dry out. The ideal place to start them is in a cold frame, where the soil can be kept constantly moist, and when the young plants appear they can be protected from heavy rains. some varieties bloom the first year from seed if they are sown early, but it is not until the second year that you get the best results, and from that on for several years these beautiful plants increase in value, affording color in the garden at a season when few, if any, annualy are blooming, and at the same time furnishing fine material for house decoration, as nost of these varieties are excellent as cut flowers. Coreopsis Lanceolata, Gaillardia Grandiflora, Shasta Daisy, and a few others are not reliable unless they are divided and reset in the early Fall after flowering, but such varieties as Delphinium or English Larkspur, Pyrethrum Hybridum, Oriental Poppy, Columbine and Sweet William may be depended unon for years. It is so much cheaper to grow them than to buy the plants. See our 50c collectiou of perennial flower seeds above. 
